\title{
Women in Politics in Matrilineal Society: A Case Study of West Sumatra, Indonesia
}

\author{
by \\ Selinaswati \\ Bachelor of Sociology (Andalas University) \\ Master of Arts (University of Hawai'i at Manoa)
}

Submitted in fulfilment of the requirements for the degree of Doctor of Philosophy

School of Humanities and Social Sciences

Deakin University

Melbourne

October 2014 
I am the author of the thesis entitled

Women in Politics in Matrilineal Society: A Case Study of West Sumatra, Indonesia

submitted for the degree of Doctor of Philosophy

This thesis may be made available for consultation, loan and limited copying in accordance with the Copyright Act 1968.

I certify that I am the student named below and that the information provided in the form is correct'

Full Name:

Selinaswati.

(Please Print)

Signed:

Signature Redacted by Library

Date: 1 October, 2014. 


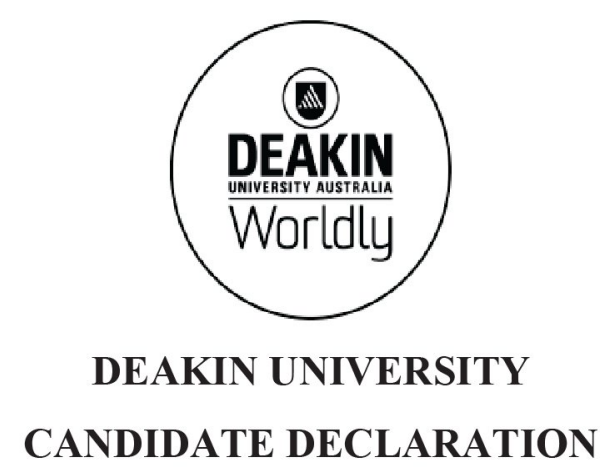

I am the author of the thesis entitled:

Women in Politics in Matrilineal Society: A Case Study of West Sumatra, Indonesia

Submitted for the degree of Doctor of Philosophy

This thesis may be made available for consultation, loan and limited copying in accordance with the Copyright Act 1968.

'I certify that I am the student named below and that the information provided in the form is correct'

Full Name: SELINASWATI

Signed:

Signature Redacted by Library

Date: 1 October, 2014 


\section{Acknowledgments}

I gratefully acknowledge my principal supervisor A/Prof. Ismet Fanany, and associate supervisors, Prof. Liz Eckermann, Prof. Damien Kingsbury and my external supervisor Prof. Marian Simms of the Australian Research Council (ARC). To A/Prof. Ismet Fanany I would like to offer an enormous thank you for the tireless readings of my draft thesis. To Prof. Eckermann and Prof. Kingsbury for their motivation, intellectual generosity and enthusiasm. I am also truly indebted to Prof. Simms for providing me with valuable feedback in the thesis process.

My deepest gratitude also goes to Dr Rebecca Fanany for her very insightful discussion, detailed comments and help in reading and editing my thesis. Your editing skills and patience made my $\mathrm{PhD}$ process easy to bear.

Thank you also for the support provided by the Faculty of Arts and Education, Research Services Division, and Library staff at Deakin University. I am especially grateful for the administrative support provided by Robyn Ficnerski and Sarah Buckler, Prof. Roger Horn of Deakin Research Training and Sally Fornaro of Deakin Research Integrity.

This study received financial support from DIKTI. I would like to thank them for awarding me a scholarship to pursue my doctoral degree at Deakin University. I would like to express my sincere gratitude to the participants in this study who gave generously of their time to be interviewed and made this thesis possible. I also wish to acknowledge the contribution of individuals with whom I came in contact with during my preparation for field research; Bapak Firman Abdullah, Husni Kamil Manik and Agustian Piliang of the West Sumatra Electoral Commission (KPU - Komisi Pemilihan Umum, Sumbar).

As a lecturer at the Faculty of Social Sciences of Padang State University (UNP - Universitas Negeri Padang), I would like to thank the Rector and Vice Rectors of UNP, Dean and Vice Deans of the Faculty of Social Sciences, the Head of 
Department of Sociology-Anthropology, administration staff and colleagues for allowing, supporting and providing me with administrative back-up during this $\mathrm{PhD}$ process.

Much gratitude also to my colleagues and friends who travelled this $\mathrm{PhD}$ journey with me and who have been a source of motivation, in particular my Indonesian office colleagues; Ima, Lia, Yeny, ni Eva, Dewi, especially to Ibu Yet who gave me a ride to the office during my hard time at the end of thesis completion. Thank you also to my Indonesian family for helping my family and for their friendship in Melbourne.

I am also grateful for the support of my father, Nasrul and mother-in-law, Irma Murni for their love and for accompanying us. I especially thank my late mother, Zaryunani, my brothers Amin and Adi, cousins and all extended family members. To my husband, Yuharzi (Da Ondang), thank you for your understanding, support and love. To my daughter Nayla Ilmanafia and my son Hamizan Nabil, who (from the time they were born and now as a toddler and a newborn baby) has endured the long sojourn of my academic endeavours; your kisses, hugs and endearing charms were always waiting for me at those moments when I needed them most. Finally, above of all, none of this would have been possible without God's blessing. 


\begin{abstract}
Studies of women in politics have mostly been done within patriarchal social structures around the world. These studies show that women have many potential opportunities to become involved in public life; as voters in elections, as political candidates, and if successful as members of the administrative class or as Members of Parliament (MPs). However, female politicians may be affected by several factors within the social, economic, political and cultural systems. This thesis examined whether the matrilineal social structure of the province of West Sumatra, Indonesia, influences women's political participation in local parliaments. West Sumatra is dominated by the Minangkabau ethnic group, which has a matrilineal tradition that provides more opportunities for women in terms of property ownership and non-household activities. It was assumed that women who were involved in local politics would be affected by these cultural values.

This research was a case study. Three categories of informants, female politicians, community leaders and voters, were interviewed to identify the strategies and experiences of female politicians and the diversity of opinion regarding female politicians in this matrilineal society. Data was obtained through fieldwork carried out from July to October 2012 in West Sumatra. During this period, in-depth, semi-structured interviews were carried out in locations where female politicians had been elected to the local parliament. Additional information was obtained from 17 voting members of the public through the use of a questionnaire. Secondary data was obtained from government documents and local parliaments, online resources, institutions and organisations.

The study found that the matrilineal system in West Sumatra inspired female politicians in their efforts to gain a seat in parliament. However, they also experienced disadvantages in the matrilineal and Indonesian political system. It was found that the opinions of community leaders toward female politicians were largely neutral and saw female politicians as comparable to male ones. The voting public tends to have less knowledge about female politicians and viewed them as not significantly better than male politicians. The study concludes that the matrilineal structure of West Sumatran society does not have much impact on women's political participation and female politicians can benefit by improving their capabilities in order to win a seat in parliament. Additionally, the Indonesian government might play a role in bridging the gap between low and high level political participation by women and develop ways to include aspects of local culture such as the matrilineal system into its policies that relate to political autonomy at the regional level.
\end{abstract}




\section{Table of Contents}

Acknowledgments

Abstract iii

Table of contents iv

List of Tables viii

List of Terms $\quad$ ix

Chapter 1 Introduction $\quad 1$

1.1. Background of the Research ......................................................... 1

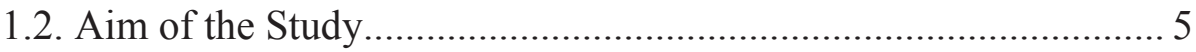

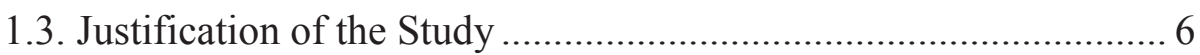

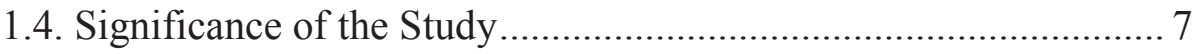

1.5. Research Questions................................................................ 7

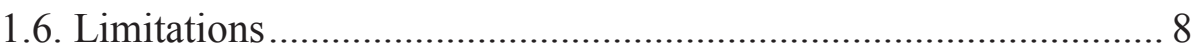

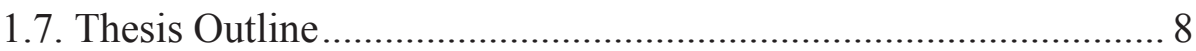

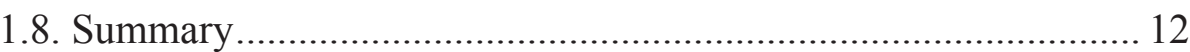

Chapter 2 Literature Review 13

2.1. Political Participation and Representation..................................... 13

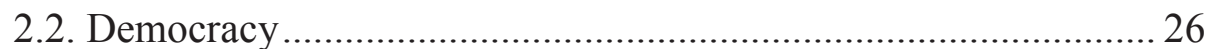

2.3. Culture and Matrilineal Society................................................... 31

2.4. Women's Representation in the Indonesian Political System ...... 36

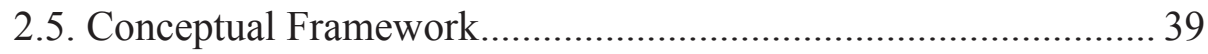

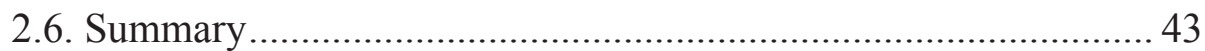

Chapter 3 Context and Background $\quad 45$

3.1. Geography and Physical Characteristics .................................... 45

3.2. Characteristics of the Matrilineal System ..................................... 46

3.2.1. Ancestral Property ................................................................ 47

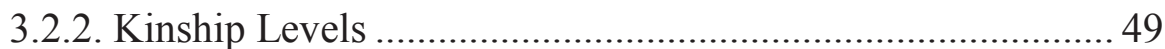

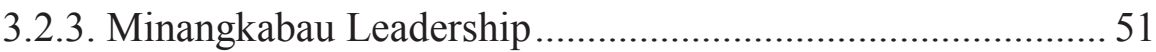

3.2.4. Adat, Philosophy, and Religion of the Minangkabau People 57

3.3. Values of the Matrilineal System .................................................58

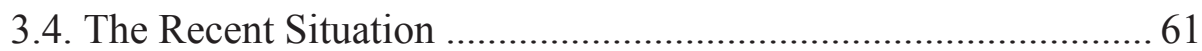


3.4.1. West Sumatra as an Indonesian Province 61

3.4.2. Population of West Sumatra .................................................. 62

3.4.3. The Dynamics and Transition of Minangkabau Culture........ 62

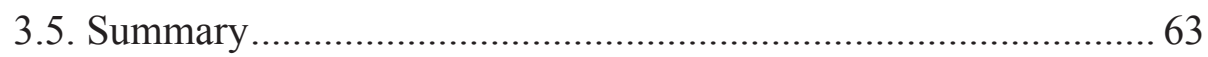

Chapter 4 Research Methodology and Design $\quad 65$

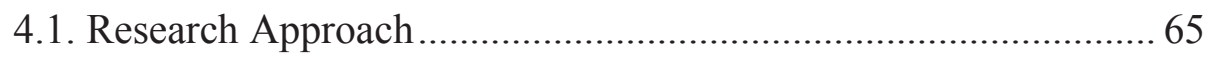

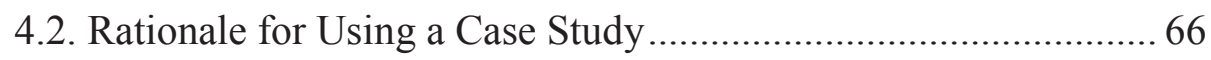

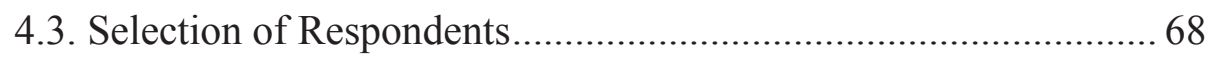

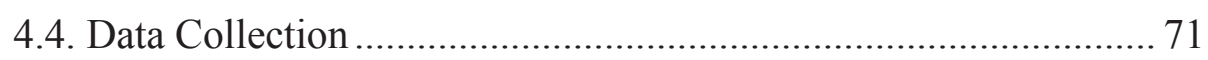

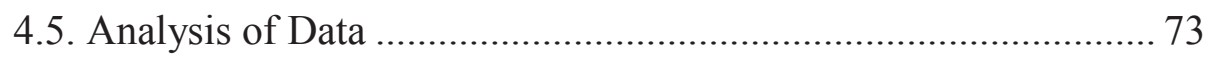

4.6. Reliability, Validity and Reflexivity .......................................... 74

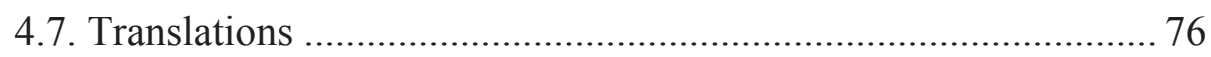

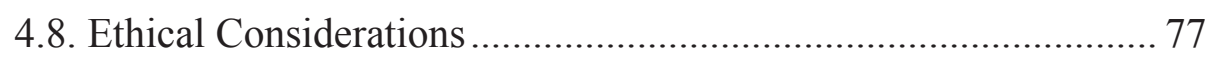

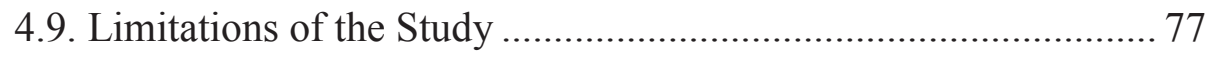

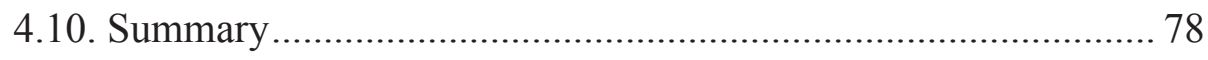

Chapter 5 Female Politicians: Pathways, Efforts and Experiences 79

5.1. The Female Politicians .............................................................. 79

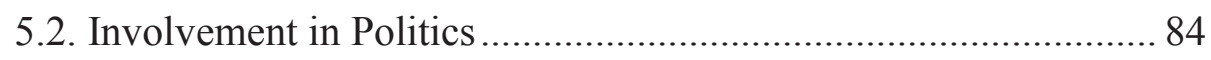

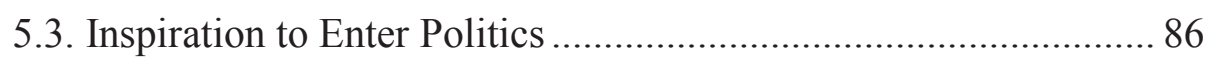

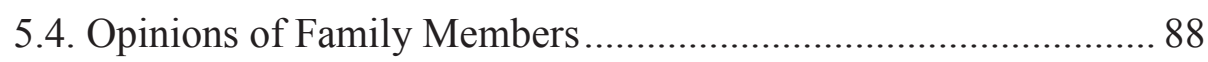

5.5. Support and Role in the Extended Family................................... 89

5.6. People and Organisations that Support Their Candidacy ............. 94

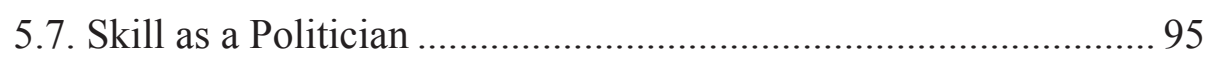

5.8. Obstacles Faced as Female Politicians …..................................... 97

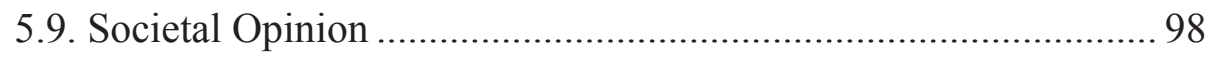

5.10. Reaction of Political Colleagues.............................................. 100

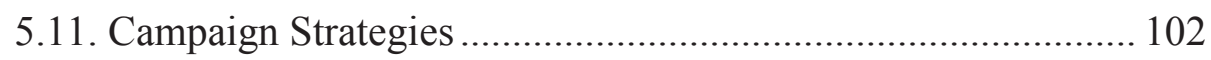

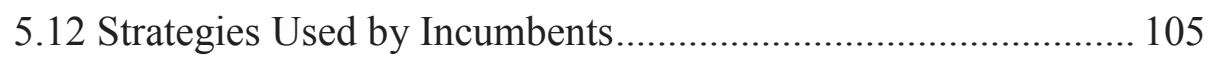

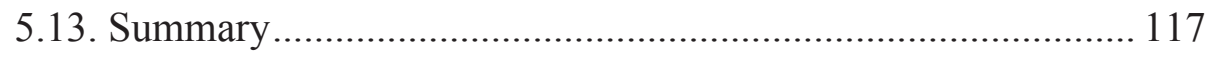

Chapter 6 Female Politicians: Views of the Public 118

6.1. Community Leaders ............................................................... 118

6.1.1. The Traditional Role of Minangkabau Women ................... 123 
6.1.2. The Relevance of Women's Traditional Role to Politics .... 126

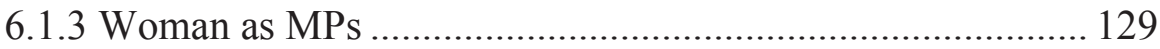

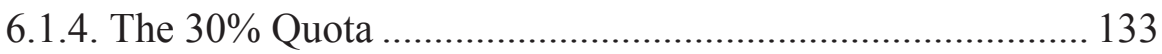

6.1.5. Women in Politics in Minangkabau Society....................... 135

6.1.6. Support for Women in Politics from Community Leaders.. 138

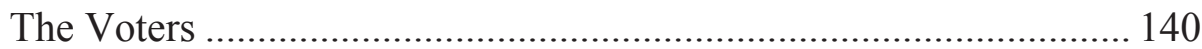

6.2. Interviews with Voters.......................................................... 141

6.2.1. The Importance of Women in Politics ................................ 142

6.2.2. The Matrilineal System and Its Benefit for Women

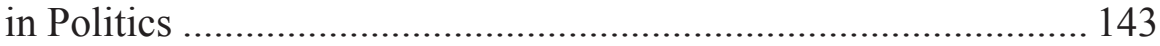

6.2.3. Considerations in Choosing Candidates ............................. 145

6.2.4. Opinions about the Performance of Female MPs ................ 147

6.2.5. Politics as an Appropriate Field for Women........................ 148

6.2.6. Trustworthiness of Male and Female Politicians ................. 151

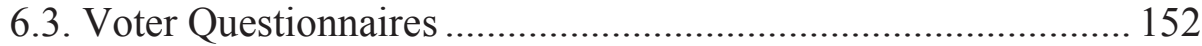

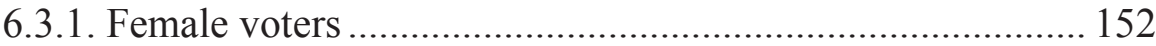

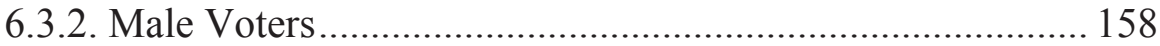

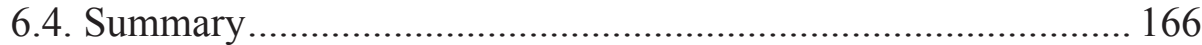

Chapter 7 Discussion and Analysis 167

7.1. Significant Aspects in Winning a Seat in Local Parliament....... 167

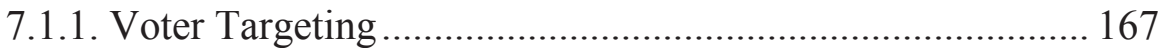

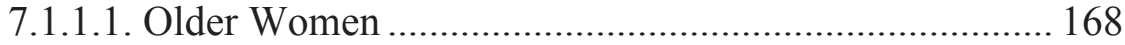

7.1.1.2. Women in Rural Areas ................................................ 172

7.1.1.3. Women in Organisations ............................................. 174

7.1.2. Candidate's Gender and Untapped Voters' Segments ......... 179

7.1.3. The Importance of Local Origin and Social Network.......... 181

7.1.4. Female Advantage ........................................................... 183

7.1.5. Family Connections …....................................................... 185

7.2. The Disadvantages of the Matrilineal Social Structure and the Indonesian Political System........................................................... 189

7.2.1. Limited access ................................................................. 190

7.2.2 Political Parties as a Doorway to Politics .............................. 193 
7.2.3. The Nature of the Quota System.....

7.3. Female Politicians in the Public View. 199

7.3.1. Voter Knowledge and Support from Community Leaders .. 200

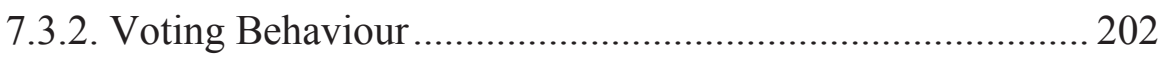

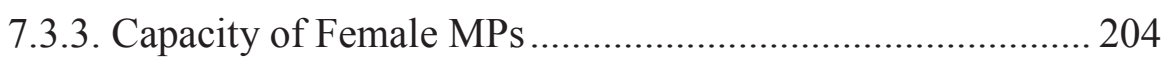

7.4. Linkages between Modern Political Life and Matrilineal Society 207

7.4.1. Corruption, Vote Buying and Personal Obligation 207

7.4.2. Political Office and Social Status. 210

7.4.3 Lack of Women in Politics 213

7.5. Summary 215

Chapter 8 Summary, Conclusions and Directions for Further Research 216

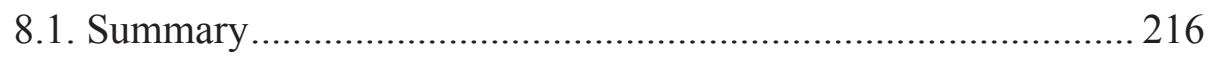

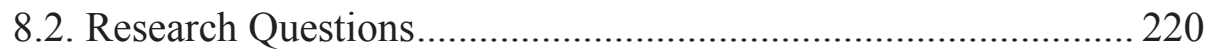

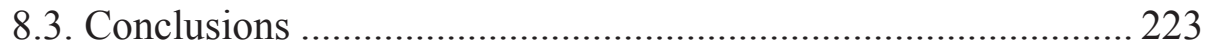

8.4. Directions for Further Research ............................................. 226

References $\quad 228$ 


\section{List of Tables}

Table 1: Number of Female Representatives \& Incumbents in the Periods 2004-2009 and 2009-2014 in West Sumatra 69

Table 2: Background of Female Politicians Interviewed for the Study .82

Table 3: Background of Community Leaders Interviewed for this Study.....121

Table 4. Female Voters' Opinion on Women, Politics and Minangkabau.....152

Table 5: Female Voters' Consideration in Choosing a Candidate

Table 6: Female Voters' Opinion about the Performance of MPs in

Parliament

Table 7: Appropriate Occupations for Men and Women According to Female Voters

Table 8: The Advantages to Minangkabau Women in Politics According to Female Voters

Table 9: Male Voters' Opinion on Women, Politics and Minangkabau 159

Table 10: Male Voters' Consideration in Choosing a Candidate 160

Table 11: Male Voters' Opinion about the performance of MPs in Parliament 161

Table 12: Appropriate Occupations for Men and Women According to Male Voters

Table 13: The Advantages to Minangkabau Women in Politics According to Male Voters. 


\section{List of Terms}

This list of terms contains definitions for non-English words, phrases, and terms used in the text of this study. All of the quotations from interviews with female politicians, community leaders and voters contained in chapter 5 and 6 are translated in the text and are not included here. The abbreviations shown in parentheses following each entry below indicate the language of the entry: Mk. (Minangkabau), Ind. (Indonesia), Ar. (Words from Arabic, used in either Mk. or Ind.) and D (Dutch).

Adat (Ind.)

Alam (Ind. Mk.)

Alam takambang jadi guru (Mk.)

Alim Ulama (Ar.Mk.)

$\mathrm{BAZ}(\mathrm{Ar}$.

BKMT (Ind.)

Bundo Kanduang (Mk.)

Bupati (Ind.)

Cadiak Pandai (Mk.)

Camat (Ind.)

Darek (Mk.)
Traditional law and custom

(Minangkabau) world

Let nature be your teacher; basic principle of the Minangkabau value system

Religious scholars

Badan Amil Zakat: a government owned Zakat Organisation

Badan Kontak Majelis Taklim: Muslim women's organisation

The true (ideal) mother

Administrative head of a regency

Intellectual

Administrative head of a district

The heartland of the area occupied by the Minangkabau people 
Datuk (Ind.)

Dharma Wanita (Ind.)

Gerwani (Ind.)

Golkar (Ind.)

Harta Pencarian (Ind.)

Harta Pusaka (Ind.)

Kabupaten (Ind.)

Kamanakan (Mk.)

KAN (Mk.)

Kowani (Ind.)

KPU (Ind.)

Kecamatan (Ind.)
An honorary title given to men as adat leaders in Minangkabau community

Civil Servants' Wives' Association; formed by Indonesian central government during Soeharto era

Gerakan Wanita Indonesia; Indonesian Women's Movement

Golongan Karya; the ruling party during the Soeharto government (1966-1998), and the biggest party in today's ruling coalition in Indonesia.

Term referring to a person's self-earned property

Term referring to communal assets of the matrilineal extended family

Administrative area usually defined as a regency

A man's niece/nephew from the maternal line; the children of the man's sisters

Kerapatan Adat Nagari; nagari board

Kongres Wanita Indonesia; Indonesian Women's Congress

Komisi Pemilihan Umum: Electoral Commission

Administrative area usually defined as a district 
Larashoofd (D)

LKAAM (Mk.)

LPM (Ind.)

Luhak Nan Tigo (Mk.)

Mamak (Mk.)
The adat leadership formed by the Dutch government during the colonial era

Lembaga Kerapatan Adat Alam Minangkabau; the Association of Adat Councils of the Minangkabau World Founded on 18 March 1966 in 1980, LKAAM was joined by Bundo Kanduang as a partner organisation to represent women's interests in the Minangkabau community. LKAAM was formed by the Soeharto government to generate sympathy among Minangkabau for his administration. During the reform era and under regional autonomy, the organisation returned to a less political role representing and promoting the Minangkabau community and its culture in Indonesia and West Sumatra.

Lembaga Pemberdayaan Masyarakat; Social Empowerment Institution

Three areas within the darek, consisting of Luhak Tanah Data, Luhak Agam, and Luhak Lima Puluh Kota. In contemporary Minangkabau society, these three luhak make up the modern regencies (kabupaten) of Tanah Datar, Agam and Lima Puluh Kota

Maternal uncle 
Marantau (Mk.)

Niniak mamak (Mk.)

Muhammadyah (Ind.)

Masyumi (Ind.)

Mahram (Ar.)

MUI (Ind.)

Nagari (Mk.)

New Order (Ind.)

NU (Ind.)

PAN (Ind.)
Minangkabau practice of migration by young men to other regions to work or for other reasons before returning home to settle

Traditional leaders

Modern Muslim organisation in Indonesia committed to furthering education and social causes

Masyarakat Muslim Indonesia; Council of Muslim Organisations

In Islam, anyone who a woman may not marry because of blood or family relationship; for example, a father, brother, uncle, or son.

Majelis Ulama Indonesia; Council of Indonesian Ulamas

The traditional administrative structure of Minangkabau society containing several villages and having its own leadership. The period of Indonesia's history when Soeharto was president, 1966-1998

Nadhatul Ulama; an Islamic traditionalist organisation

Partai Amanat Nasional; National Mandate Party, a moderate Islamist political party that was established in 1998. 
PBB (Ind.)

Perwari (ind.)

PPP (Ind.)

Parmusi (Ind.)

PDI (Ind.)

Pemandian (Ind.)

Perti (Ind.)

PKI (Ind.)

PKK (Ind.)

PSII (Ind.)

Rantau (Mk.)
Partai Bulan Bintang; Crescent and Star Party, one of the moderate Islamist political parties that was founded in the early Reform era in 1998

Persatuan Wanita Republik Indonesia; Union of the Women of the Indonesian Republic

Partai Persatuan Pembangunan; the United Development Party, which has existed since the New Order Era

Partai Muslimin Indonesia; the Muslim Party of Indonesia

Partai Demokrasi Indonesia; the Indonesian Democratic Party

Bathing place, usually for the public in a given community

Persatuan Tarbiyah Indonesia; the Islamic Educational Movement

Partai Komunis Indonesia; the Indonesian Communist Party

Pendidikan Kesejahteraan Keluarga; Family Welfare Education Group

Partai Syarikat Islam Indonesia; the Islamic Association Party of Indonesia Term referring to the region outside the traditional Minangkabau homeland 
Rajo Adat (Mk.)

Rajo Alam (Mk.)

Rajo Ibadat (Mk.)

Reform Era (Ind.)

Rumah Gadang (Mk.)

Samande (Mk.)

Sapariuak (Mk.)

Saparuik (Mk.)

Sapayuang (Mk.)

Tungku Tigo Sajarangan (Mk.)
Term referring to a person who has power in terms of adat

Term referring to a person who has power in the context of the Minangkabau world Term referring to a person who has power in terms of religion

The period after the fall of the Soeharto government in 1998

Traditional house of the Minangkabau ethnic group with a buffalo horn-shaped roof housing the extended family which can include two or three generations from the maternal line

Originating from the same mother; term referring to the Minangkabau nuclear family

Eating from the same cooking pot; term referring to the Minangkabau nuclear family

Originating from one female ancestor; term referring to the Minangkabau extended family

Originating from one clan; term referring to the Minangkabau extended family The three part system in Minangkabau society consisting of adat leaders (Datuk Penghulu or niniak mamak), religious 
leaders (alim ulama) and intellectuals or scholars (cadiak pandai).

Tuanku Lareh (Mk.)

Tungganai (Mk.)
Term referring to the person who led adat institutions under the Dutch colonial government

The maternal uncle who heads the lower level of the nuclear family (Sapariuak) 


\section{Chapter 1}

\section{Introduction}

This chapter provides an introduction to the research reported here. It argues that the characteristics of matrilineality in West Sumatra, including a perceived egalitarianism that values women's position and provides opportunities for women in non-household activities, might have a positive influence on the experiences of women in politics that may be significant in increasing the number of women who can take part in the state's democratic institutions. This introductory chapter is divided into seven main sections which describe the research background; the aims, justification, significance of the study; its research questions, limitations, and a thesis outline.

\subsection{Background of the Research}

Women involved in politics can be seen in different contexts, such as through their participation as voters in elections, their involvement in the political arena as candidates, and as members of the bureaucracy, political offices, or parliaments. This research examines women's political participation and their election as members of local parliament in the Indonesian province of West Sumatra. This participation of women in politics has been the subject of considerable research that has often associated it with the goals of equality and justice and the practice of democracy. Despite the establishment of candidate quotas and other measures to increase women's participation in politics, one finds that in many parts of the world women's involvement is, still considerably less than that of men; that is, less than one out of five members of parliament is a woman (Dahlerup 2005; Inter-Parliamentary Union 2014; Stockemer 2009).

Over the past several decades, a large number of social, economic, and institutional factors have been identified that might affect women's participation in politics. Even in developed economies, women's political 
participation has generally not achieved the levels of participation by men (Norris \& Inglehart 2003; Paxton \& Kunovich 2004). A range of factors has been identified, including economic factors such as human and financial capital and the presence of female workers in the public space, which may contribute to whether it is advantageous for women to engage in political activity in these developed countries. However, other factors, such as institutional structures including government rules, political parties and the nature of the electoral system, such as any quota system and proportional representation, may influence the strategies of political parties in supporting female candidates (Paxton 1997; Rule \& Zimmerman 1994). Also, there is an idea that women's representation has a strong correlation with political culture. For example, women who live in regions that value gender equality might have wider opportunities to represent their community in politics (Thames \& Williams 2013). However, a number of barriers for women in entering politics have been widely observed and include gender stereotypes, career choices and preparation, family demands, gender discrimination and the conventions of the political system, including money or fund raising, party organisation and support, the advantage of incumbency and the way the electoral system works (McGlen et al, 2011).

The desire to achieve a greater degree of gender equity has become something of an international priority. For example Celis, Krook and Meier (2011) found that more than 50 nations with democratic, semi-democratic, and nondemocratic government systems have instituted reform aimed at increasing the level of women in politics. This suggests that the participation of women in politics is viewed as beneficial regardless of the exact social context and is seen as having the potential to enrich the political system no matter what form that system takes.

The presence of more women as candidates and policy-makers is often expected to allow more women's issues to become mainstream as part of 
campaign agendas (Childs \& Withey 2004). Men and women tend to use different style campaign strategies, women are more likely to campaign on social issues, many of which are seen as more important to women or relate more to their experiences (La Cour Dabelko \& Herrnson 1997; Thames \& Williams 2013). However, it should be noted that a number of studies have failed to demonstrate that greater female participation in politics achieves these effects. In some cases, it has been shown that the existence of women in leadership positions tends to have little effect on whether citizens of both sexes see these leaders as effective and representing their interests (Karp \& Banducci 2008).

Despite the recognized advantages of greater participation by women in politics it has been observed that women tend to be less interested in politics than men and also less engaged (Karp \& Banducci 2008). Similar findings have been reported for the US, where a majority of the available research has been done (Lawless \& Fox 2005; Verba, Schlozman \& Brady 1995) and also in other parts of the world (Christy 1987; Iwanaga 2008; Norris \& Inglehart 2003). For this reason, it has sometimes been suggested that many societies maintain a patriarchal social outlook that affects the way women are viewed (Lerner 1986), and that may suggest politics is not an appropriate area of participation for them. This ideology encompasses both the social, political structure and affects cultural-structural factors (Paxton \& Kunovich 2004). As can be seen in some situations, women themselves may be unable or unwilling to abandon these social constraints and lack of personal agency may be a factor in some situations where women's participation in politics is low (Gelb \& Palley 2009).

To date, the majority of studies on women's political participation have been carried out in countries and political systems that maintain a patriarchal social orientation. As described by Ford (2010), it is generally assumed that this social orientation accounts for the widely observed phenomenon that fewer 
women participate in politics than men. This study will complement previous research by considering the issues surrounding women's participation in politics in West Sumatra, Indonesia. West Sumatra is one of 33 provinces in Indonesia and is populated almost entirely by the matrilineal Minangkabau people. Matrilineal system govern the life and societal structure are based on matrilineality of Minangkabau kinship (Radjab 1969). It is hypothesized that the matrilineal system in this region will give rise to forces that contribute to differential political engagement among men and women in a system where patriarchal heritage should not be in influencing their social behaviour.

Women in this area have specific traditional roles and responsibilities to their community outside the domestic space (Vreede-de Stuers 1960). Vreede de Stuers suggests that the position of women in Indonesian society can be understood through an examination of social relationships between men and women in three principal systems; the matrilineal system, the patrilineal system, and the bilineal system. The patrilineal and the bilineal systems give dominance to men in the social environment culturally, while the matrilineal system positions women in a central role in community life (Vreede-de Stuers 1960). The Minangkabau society of West Sumatra is an important example of a matrilineal system in which women hold considerable influence because of the economic system that transfers assets through the female line (Vreede-de Stuers 1960).

Blackwod (2005) notes that senior Minangkabau women especially in rural areas have control over their ancestral property. As a result, most women are able to fulfil their basic needs, as well as those of their extended family. The fact that these older women are the heads of household indicates that this is a matrifocal community, a society which is mother-focused.

In the modern Indonesian political context the current environment of the Reform Era, which began in 1998, has been significantly different from the 32 years New Order of former President Soeharto. The current context is 
characterized by regional autonomy which transferred authority for a range of services and functions to regional government. This has significantly affected Indonesian democracy and political life. In the Reform Era, Indonesia passed new laws including those concerning local governance and the financial relationship between the central and regional governments that give more power to local legislatures than to the local executive branch. This has resulted in greater authority for the local parliament (Holtzappel 2009; Sarundajang 2001). Additionally, unprecedented latitude has been given to lower levels of administration to manage various aspects of the public sphere (Holtzappel 2009). This change in the political system is important in understanding Indonesia's political experiences in terms of women's political participation at local and provincial levels. For this reason, a study of the experience of female politicians and their pathway to political office will provide insight not only into the situation of women in politics in Indonesia but will also contribute to developing an understanding of the impact of Regional Autonomy.

\subsection{Aim of the Study}

This research aims to identify and analyse the set of social and cultural issues that relate to the participation of women in politics in the Indonesian province of West Sumatra. It will attempt to determine whether the values of a matrilineal system in Minangkabau society might facilitate women's social and leadership roles in politics. The cultural context and social structure of West Sumatra are unique in Indonesia in terms of their matrilineal nature and the traditional position accorded to women within the system. Nevertheless, West Sumatra is part of the Indonesian national system and is not different in political structure from the rest of the nation's provinces. An assessment of the factors that affect women's involvement in politics in this social context and shape their experiences once in parliament will provide valuable insights into the role social and cultural context play in political participation. Further, as matrilineal society gives certain privileges to women there may be aspects 
of this context that can offer a greater understanding of how social position relates to political participation.

\subsection{Justification of the Study}

The differential participation of men and women in politics is considered a matter of importance in many parts of the world and electoral reforms have been undertaken around the world to address this issue (Celis, Krook \& Meier 2011). At the same time, there are indications that such reforms have had considerably less impact than intended. Recent data from the InterParliamentary Union noted that 187 countries around the world allow women to run for office and many parties including government, non-government organisations and women's activists support the involvement of women in politics. The effort of many countries to increase the number of women participating in the political system can be seen in the enactment of policies relating to women's suffrage, aspects of the electoral process that address women's participation, and quota systems. Nonetheless, the number of female politicians, who have been elected as representatives in local parliaments in the majority of countries is less than $20 \%$ of the total members (InterParliamentary Union 2014). This suggests that there are factors in many different political systems that affect women's participation in politics such that the desired level of gender representation is difficult to achieve.

The current literature focuses on increasing the number of women in political participation and representation by analysing the structure of political systems in terms of the role of parties and electoral reform. In fact, it has been suggested that political parties, in selecting and promoting candidates, are motivated less by strategic advantage than by social values, norms, and ideologies (Celis, Krook \& Meier 2011; Pilet \& Bol 2011). This highlights the importance of the social and cultural context as noted by Karp and Banducci (2008) among others. Because the social and cultural context in a majority of study areas has been patriarchal in nature, we know little about how an underlying social and 
cultural context that favours women in positions of decision-making authority might impact on political participation. This study will provide this information and will allow for a more nuanced understanding of women's participation in politics in the context of the relevant social and cultural determinants.

\subsection{Significance of the Study}

Studies of women's political participation have been carried out in many countries around the world and the social, structural and cultural determinants that influence it have also been considered. Nonetheless, most of these studies have focused on communities and social contexts with an underlying patriarchal structure. Matrilineal cultures are not common in the modern era and those that exist are often small groups that are not fully engaged in the modern political life of the nation in which they exist (Bowie 2008; Farrar 1997). In West Sumatra the role of women in politics has been considered historically (Hadler 2008). Kinship, women's roles in traditional institutions and in decision-making have also been discussed (see, for example Afrizal 1996; Blackwood 2000; Sanday 2002). However, these studies have not extended to the experience of female politicians in the modern context of the Indonesian nation. This study will fill this gap.

\subsection{Research Questions}

This study seeks to answer four related research questions. They are:

1. What are the relevant characteristics of female politicians in matrilineal society of West Sumatra?

2. What kind of efforts do female politicians in West Sumatra make and what are their experiences in winning seats in the parliament?

3. How does the voting public in this matrilineal society perceive female politicians as candidates? 
4. How does the Minangkabau matrilineal system affect women's political participation?

These research questions are intended to allow for a description and analysis of the experience of female politicians in West Sumatra in the context of Indonesia's current political system. It is intended that their answers, as derived from the findings of this study, will contribute to an understanding of the political, social and cultural context and the ways in which these aspects of modern society relate to political participation by women from the matrilineal Minangkabau ethnic group.

\subsection{Limitations}

This study has several limitations. First, it was conducted in only one part of Indonesia and this region has a distinct social structure that is not found elsewhere in the country. For this reason, the factors that affect women in this location may not be identical to those experienced by women elsewhere in the country and in the world. Second, only five female politicians took part in this study. While this did allow for an in-depth elucidation of their experience, this may not be representative of all female politicians in this or other regions. Finally, because the politicians who took part in this study were required to have been elected to office since the implementation of regional autonomy, the study does not consider the experience of women who were active in politics during the New Order or at other times. Nonetheless, these limitations do not detract from the significance of the findings of this research. As a case study, the experience of these women provides considerable insight into the political context in this region and the role its traditional culture plays in the participation of women in the political environment.

\subsection{Thesis Outline}

This thesis contains eight chapters: Chapter 1 introduces the study; Chapter 2 reviews literature relevant to this research; Chapter 3 presents the background and context of research which describes the matrilineal system of West 
Sumatra in detail; Chapter 4 discusses the research methodology and design used; Chapter 5 presents the findings from in-depth interviews with five female politicians from West Sumatra; Chapter 6 contains findings based on interviews with community leaders and a survey of voters; Chapter 7 discusses the values of the matrilineal system in relation to the political participation by women in West Sumatra; and Chapter 8 contains the study's conclusions and directions for further research. A summary of each chapter follows.

\section{Chapter One - Introduction}

This chapter introduces the study by establishing the background of the research and research questions. The chapter presents an overview of women's political participation in relation to the small number of female MPs in national and local parliaments around the world. The small number of women in parliament may have been affected by several factors, social and cultural factors. Studies about women's political participation have largely been carried out in societies with patriarchal social structures. By contrast, this study focuses on the specific matrilineal culture of West Sumatra in order to identify the nature of the influence of a matrilineal system on women's political participation in local parliament.

\section{Chapter Two - Literature Review}

This chapter presents a review of relevant literature related to women's political participation and representation in the political environment. The review discusses the nature of women's political participation around the world specifically in Europe, the US, Africa, and Asia. The concepts of democracy, culture and matrilineal society are discussed in this chapter as well. Finally, the conceptual framework for the study is discussed in the context of a model of political recruitment, the concept of political supply and demand and a model of political participation.

Chapter Three - Context and Background 
This chapter describes the background and context of matrilineal society of West Sumatra. It is based on existing literature and also includes the experience of the researcher as a member of this community. The chapter provides detail about the values and characteristics of matrilineal society as a framework for this study. Four major characteristics of the matrilineal system are discussed - namely ancestral property, kinship levels, Minangkabau leadership and adat, philosophy and religion. The values of the matrilineal system such as egalitarianism, progress and development, are explicated in detail in this chapter. This chapter also discusses the recent situation in West Sumatra which focuses on the integration of the traditional matrilineal system and the modern Indonesian political system in this region.

\section{Chapter Four - Research Methodology and Design}

This chapter discusses the methodology and analysis used in this study. It outlines the choice of a case study methodology and discusses the methods of analysis used. Further, the chapter outlines the procedure used for data collection for both primary and secondary data. It also describes the procedures used to select respondents: Context and Background, how interviews and observations were done and discusses considerations of research validity and ethics.

\section{Chapter Five - Female Politicians: Pathways, Efforts and Experiences}

This chapter presents the results of in-depth interviews carried out in the field. Its findings are categorized into themes that include the involvement of women in politics, their background and role in the extended family, their experiences as politicians, their strategies during campaigns and elections and their opinions regarding how society views them as politicians. These findings include direct quotations to illustrate the way the women interviewed understand their own situation. These quotations are presented in their original language (Indonesian and/or Minang) and are translated in the text. 
Chapter Six - Female Politicians: Views of the Public

This chapter presents findings about the perceptions of community leaders and voters. It highlights their opinions about Minangkabau women as politicians, their views on the traditional role of Minangkabau women, their opinions on the relationship between women's political activities and their traditional roles, the position of Minangkabau women within the Indonesian political system and their reasons for choosing a candidate to vote for.

\section{Chapter Seven - Discussion and Analysis}

Based on the findings reported in chapters five and six, this chapter analyses and discusses the influence of various factors that affect women's political participation in the matrilineal society of West Sumatra and the opinions of community leaders and voters toward female politicians. This study found that Minangkabau women as politicians have advantages they can use in the political process as candidates and MPs. In addition, they experienced some contradiction between their political activities and traditional culture. This chapter argues that the matrilineal system in West Sumatra has only a minor effect on the career of female politicians in the region since the traditional culture of matrilineal society cannot fully transfer to the Indonesian political system. This study suggests that the abilities and capacities of female politicians are more important than the status conferred to them by the traditional matrilineal system.

Chapter Eight - Summary, Conclusions and Directions for Further Research This chapter reviews and summarizes the main points of previous chapters. It presents the research questions used to structure the study and presents the answers to those questions based on its findings. It also contains the study's conclusions and recommends directions for future research. 


\subsection{Summary}

This chapter introduced the thesis by arguing that women who are involved in local politics in West Sumatra might be affected by the cultural values of matrilinealism. It described the background of this study and defined its aims, justification and significance. The research questions the study intends to answer were presented along with the study's limitations. These aspects of the research are further elucidated in the remaining chapters of this thesis, beginning with a review of literature that is contained in Chapter 2. 


\section{Chapter 2}

\section{Literature Review}

In this chapter, the literature reviewed encompasses five areas that have a direct bearing upon and understanding of the processes that lead to the election of women in Indonesia. They are: women's political participation and representation in a comparative perspective; democracy and the role of democratic political parties in terms of their opportunities they provide for women in politics; the matriarchal societies culture across the globe; the Indonesian political system and efforts to increase the number of women in politics in the short and medium period; and finally, the theoretical framework for this study that supports the research reported below.

\subsection{Political Participation and Representation}

Researchers interested in women, politics and gender have commonly used the concepts of supply and demand to explore women's political representation. Supply, in this context, is related to the resources and motivations women may possess as potential future politicians. The experience and commitment of women politicians may affect their performance in competition with male politicians. Such resources may include energy, time, money, skill and prior experiences in the political arena and also motivation. Demand relates to the characteristics of specific political aspects such as political culture, electoral systems and political parties and the preferences and opinion of political elites. All of these may result in bias and discrimination on the part of selectors; and there may be important 'interactions' between supply and demand (Norris \& Lovenduski 1995). On the demand side, external factors such as international reputation or prestige, may influence perceived political benefit and also transnational networks and global qualifications of women's politicians may support their political career (Htun \& Jones 2001; True \& Mintrom 2001). 
The level of qualifications held by such women will also affect supply. However, it has been suggested that rising levels of education and participation in the general workforce has been associated with increased political activity by women (Krook 2010; True \& Mintrom 2001). A number of factors have been identified that relate to the supply of women to potentially fill political office. These include interest on the part of women qualified to run (Escobar-Lemmon \& TaylorRobinson 2005). As the number of women participating in politics in any given level of office begins to increase, a trend towards the sustainment of such levels may be observed (Davis 1997). Several authors have noted that political experience is the main path by which women tend to be successful in gaining parliamentary positions (Davis 1997; Kobayashi 2004; Norris 1997).

A separate set of issues is observable in the context of demand. For example, in several western countries left-leaning parties tend to be more open to women's participation than right-leaning parties (Escobar-Lemmon \& Taylor-Robinson 2005; Studlar \& Moncrief 1999). In some parliamentary democracies, however, right-leaning parties have made an effort to recruit women in order to compete better against other parties (Caul 2001; Escobar-Lemmon \& Taylor-Robinson 2005). In fact, it has been suggested that competition between parties should be beneficial to women as each party tries to capture female swing voters (Sainsbury 2004; Studlar \& Moncrief 1999).

One of the difficulties with the supply and demand model is that it does not explain why women tend to be under-represented in political office in every country around the world. Krook suggests this may be because the operation of these principles can also be affected by structural characteristics of different societies that obscure variation (Krook \& Mackay 2010). However, the supply and demand model can be extended to consider structural, contextual, and social conditions (Krook 2006; Krook 2010). Krook notes that studies on women's political participation and representation interpret issues of supply and demand in different ways. She further notes that these concepts seem to be economic but 
they do not focus on efficiency and equilibrium as in economics. Supply and demand in the 'political market' generally takes into account gender norms and also the functioning of political parties (see, for example Franceschet 2005; Lawless \& Fox 2005). In other words, this model is one possible means for analysing gender discrepancies in politics using an economic metaphor.

Still in the frame of supply and demand, structural, contextual and social conditions have affected women's representation and political participation. Paxton and Kunovich (2004) consider under-representation of women from the point of view of social structures, political structures, and ideological explanations. According to them, supply relates to existing social structures such as women's access to educational and professional opportunities that may result in a greater capacity to participate in the political process (Paxton and Kunovich 2004). The relationship between educational attainment and access to resources is well established. Individuals with higher levels of education tend to have enhanced potential for achievement in the economic and social spheres and this may be especially relevant to women at the present time. For women in the specific context of politics this may extend to the ability to empower themselves (Norris \& Inglehart 2003). Nonetheless, there is some evidence to indicate that the level of education is not directly correlated with female participation as political candidates because there may be structural factors that influenced their electability (Bylesjoe \& Seda 2006; Dahlerup 2005; Norris \& Inglehart 2003).

Paxton and Kunovich (2004) suggest that political and electoral systems may present structural barriers to women attempting to enter the political arena. Various electoral systems, such as proportional representation (PR) and quota systems may affect the opportunities available to women in the political environment generally by supporting their entry into politics (as in the case of quota systems) or sometimes by hindering it. These elements of the structural environment may have a significant impact on political participation by indirectly maintaining the status quo. PR systems have been noted to allow more women 
to enter office than direct election systems (Caul 2001). However, in these cases, it is often the electoral practices and norms that lead to this result, as parties seek female candidates to balance their lists (Krook 2010; Matland 1995).

Once in office, it has often been assumed that female politicians represent the interests of women that can be seen in terms of the concepts of formal, descriptive, and substantive representation (Childs 2008; Iwanaga 2008; Paxton \& Hughes 2007). These authors note that formal representation is related to the legal right of women to participate in politics such as being voters and running for office. The descriptive perspective focuses on the increasing number of elected female politicians as a symbol of gender equality and, according to Krook (2006), this descriptive representation is based on sex alone. For Xydias (2007) and Franceschet and Piscopo (2008) the descriptive representation relates to the presence of women in elected decision-making roles. These views of descriptive representation suggest that women should have greater opportunities to be involved in the political system since parliaments around the world generally have a disproportionately small number of female legislators. In this perspective, politics is seen as being typically dominated by men and representational equity might be achieved by encouraging the involvement of more women. Several authors have developed models using this descriptive perspective that suggest the presence of women is required to legitimize the institution and are important to achieve social justice (see, for example, Mansbridge 1999; Young 2000). However, it is not clear that the mere presence of women in some number means that these individuals will act for women's interests. This dilemma is discussed in detail by Mackay (2008).

The substantive perspective on women's political representation suggests that increased numbers of female participants would have a significant impact on representation, requiring politicians to speak for and act to support women's issues (Paxton \& Hughes 2007). Women's substantive representation refers to the promotion and attention to women's interest in debate and in legislation 
(Franceschet \& Piscopo 2008; Xydias 2007). This claim is based on a concept of gender that holds that women and men have different experiences and priorities relating to political issues Krook (2006). Most existing research on women in politics however, takes a descriptive perspective by charting the numbers of women at all levels of politics such as in nominations for legislative office, becoming candidates, being elected to political office, and serving as a member of the political executive. Nonetheless, efforts to increase women's participation in politics are often based on the view that this would lead to greater focus on women's issues and policies that are particularly relevant to the experience of women (Iwanaga 2008) although it is not certain that this outcome would result.

Regardless of the perspective, political participation is to some extent controlled by political elites. Lovenduski (1993) and Simms (1993) argue that the political behaviour of party elites can be viewed from a feminist perspective and that the penetration of feminist ideas has influenced the development of party gender politics. A patriarchal system as described by Lerner (1986), exists in much of the world. This is based on the idea that the interests of men tend to take precedence over the interests of women (Lerner 1986). Further, Paxton and Hughes (2007) suggest that patriarchy is a term that describes a social system where men dominate over women and this may be manifested in social, political and economic institutions. The domination of men can often be seen in economic institutions. Witz (1992), for example, describes how women's jobs have traditionally been seen as 'caring' in nature and as an extension of the domestic sphere. In the context of the political environment, it has been suggested that this separation of the public (male) realm from the domestic (female) realm continues to form the basis of democracies worldwide (Phillips 1998 ; Rai 2000).

As gender is defined as being socially constructed, the roles that are considered appropriate for males and females to play have often been determined by biological characteristics. Norris and Inglehart $(2003$, p. 8$)$ refer to the often 'rigid gender roles' found in many societies and suggest that these social and cultural 
norms will influence the political process in a particular society as well as the political situation (Paxton \& Hughes 2007). One example of this pertains to women in lower-level jobs. Research was conducted by Niven (1998) in four states in the US that found that discrimination against female politicians was evident, especially at the local level. He concludes that the male majorities in political parties may make it difficult to change prevailing patterns and structures such that it may be difficult for female politicians to gain political status. The Inter-American Commission on Women for example, has argued that customary practices of political parties and government that are based in socio-cultural norms contribute to low numbers of women holding political office around the world - a situation that requires attention (Inter-American Commission on Women 1999). These socio-cultural norms are often viewed as limiting women's access to the political arena. Similarly, Lovenduski and Karam (2002), Paxton and Kunovich (2004), Krook (2006) Paxton and Hughes (2007) and Lawless and Fox (2005) also argue that women's participation in politics is much more complex than a simple correlation between access to the political arena and being elected to office. There appear to be other factors that influence women's decisions to enter politics and also the kind of longstanding social and cultural factors discussed above that may make this difficult when they do choose to do so. The impact of older cultural norms, social ideas held by both men and women and social structures that facilitate political participation by one sex more than the other, must be considered.

Inglehart and Norris discuss a 'rising tide' phenomenon that indicates that much of the world in the final decades of the twentieth century began to accept the importance of gender equality (Norris \& Inglehart 2003). This has been seen as a diffusion of policy, in this case from western nations to other nations. Towns (2012) discusses this phenomenon in the context of quotas for women in the political environment as an example of how social ideas about what is beneficial spread. She notes that the manifestation of this view as exemplified by the establishment of quotas, began in Latin America and has spread around the world. 
The establishment of quotas of this kind was supported by various international organisations such as the UNDP and the World Bank (Bush 2011; Krook 2009).

Research in Latin America, Europe, and Sub Saharan Africa has shown that, even though some countries have increasing numbers of women represented in their local and national parliaments, women still participate less in politics than men. This difference has been ascribed to a combination of circumstances that may be unique to each location of interest. Reviewing a number of recent studies, Krook and Jalalzai (2010) found that the lower rate of women's participation in politics occurs for different reasons in different locations. For example, research in the US conducted by Lawless and Fox (2005) found that women often have less ambition than men to enter politics. This may be because traditional social roles for women still influence women in their choice of career such that participation in the public realm in roles traditionally held by women, such as nurses, secretaries or teachers, may be more attractive. In general, research in this area has found that women tend to be less interested in politics and may also be less knowledgeable (Karp \& Banducci 2008). In Europe, the numbers of women in the national and local parliaments vary depending on country. In Finland, Norway, Denmark and Sweden, women make up between $20 \%$ and $30 \%$ of the parliaments on average. This has been the case since the 1970 s and is higher than other countries around the world. Despite ranking at the top of the range for women in political office these Scandinavian countries have long traditions of concern for social equality and supportive publics who are open to efforts such as quota policies. However, it took some 60 years for these countries to achieve their current levels of participation using an incremental approach (Dahlerup \& Freidenvall 2005; Norris \& Inglehart 2003).

Dahlerup and Freidenvall (2005, p. 29) argue that there are two ways to increase the number of women in parliament: incrementally and by the 'fast track'. The incremental approach is a process where the election of women politicians to parliament depends mostly on the women themselves. It suggests that women 
politicians need to empower themselves through increased education and build their capacities and that there is no need for specific affirmative action. By contrast, the fast track is a means for women politicians to gain seats in parliament through affirmative action measures such as a quota system.

Quotas may compensate for any structural barriers faced by women in politics and are not designed to discriminate against male politicians or political aspirants. Research by Kantola (2009) showed that affirmative action policies such as quota systems have resulted in a dramatic increase in the number of women in the single or lower house of parliament in some European countries in the past several decades, including in Belgium from 9.4\% (1992) to 34.7\% (2007), in the UK from $9.2 \%$ (1992) to $18.2 \%$ (1997), and in France from 3.7\% (1992) to $18.5 \%$ (2007). Further, she described the contradictory phenomenon where women's participation in some European countries has increased only moderately and tends to remain low such as in Greece (13\%), Hungary (10.4\%) and Malta (9.2\%). Turkey also has a small number of women in parliament, having increased from $1.8 \%$ (1992) to 4.4\% (2007) (Kantola 2009, pp. 385-6). However, the quota system in developing countries in Latin America, Sub Saharan Africa and Asia has influenced the number of women in parliament to a greater extent (Bylesjoe \& Seda 2006; Dahlerup 2005).

Research in Latin America by Alcântara Costa (2010) found that women's political participation in the context of having the right to vote did not necessarily lead to increasing women's representation. Women have had the right to vote since 1929 in Ecuador. Brazil and Uruguay followed in 1932, other countries in the 1940s, and then Paraguay and Columbia in 1961 and 1964. A strong effect was seen in Argentina and Costa Rica with high numbers of women in parliament once a quota system was introduced. Other countries in Latin America such as Mexico, Ecuador, Brazil and Peru, have not been affected much by the quota system. Further she suggests that the quota system in Latin America was not guaranteed to increase the number of women in parliament and has not 
necessarily created a political pathway to power for female politicians. She believes the cause of this phenomenon is that different countries in Latin America have different ways of implementing quotas. Some countries have enacted quota systems with penalties to political parties that break the law, while other countries do not have strong enforcement (Alcântara Costa 2010).

In sub-Saharan Africa, women's political participation and representation developed differently. For some decades there were few women in politics in sub Saharan Africa but social and political change allowed women to become more visible in politics with the establishment of electoral democracy and affirmative action programs such as quota systems emerged in some areas (Karam 1999a). In the 1960 s only $1 \%$ of politicians were women. By 2003 this had reached $14.3 \%$. Rwanda even achieved the highest percentage of women in parliament in the world in 2003 (Paxton \& Hughes 2007; Tripp et al. 2008). Another five countries, Mozambique, South Africa, Tanzania, Uganda and Burundi, were among the top 20 in terms of women's parliamentary representation (Inter-Parliamentary Union 2014; Tripp et al. 2008). The increasing number of women in parliament in this part of the world has been attributed to four main reasons. They are: the emergence of active women's movements; openness to international norms including the adoption of quota systems; women's rights and representation; and the availability of resources to advance women and give them political opportunities following the resolution of conflict in several locations (Tripp et al. 2008). Even though women's representation in parliament seems to be growing, most countries in sub-Saharan Africa still face severe problems relating to women such as poverty and starvation, domestic violence, and high infant mortality (Paxton \& Hughes 2007). According to them, these problems may be alleviated by the election of more women in the legislature to voice these issues.

International research has shown that the situation elsewhere in the world is quite different. Stockemer (2008) compared women's political participation in several European countries and the Americas. He found that there are five factors that 
can affect women's political participation: type of electoral system; quota systems; length of time women have had the right to vote; number of women with higher education and paid work; and the level of the country's development. Using a quantitative statistical regression to compare 30 countries in Europe and 30 countries in North and South America, Stockemer found that these five factors had different effects on the lower level of the national parliament in these countries in 2007. Comparisons were matched for quotas, women with paid work, and level of education. Three factors, the type of electoral system, length of women's suffrage, and level of country development, had an effect in Europe.

Studies on women's political participation in Asia have highlighted another set of issues in different countries that relate to political structures and political policies, as well as social structures, the contextual setting, cultural issues, norms, and religion. For example, in China, Howell (2006) found that women faced two main barriers to political participation and representation in the local parliament. First, some women had a lack of self-confidence that made them reluctant to be candidates (a supply factor). Second, predominant social structures did not support women entering a traditionally male field (a demand factor). Many women also had relatively low levels of education that made it difficult for them to actively participate in the political system and challenge the political control historically held by men.

Similarly, it has been suggested by Jacobsen (2008) that women in Cambodia have been marginalized in the political arena. Even though female activists were involved and played an important role in the process of reconstruction and reconciliation following the end of the Khmer Rouge period, they have not been able to leverage this involvement into formal political participation. While the government aims to increase the number of women in politics and, in that way, improve gender equity in the society as a whole, Jacobsen suggests that these policies have not been realized. She concludes that the Cambodian situation 
represents an example of a gender equality initiative for women that cannot be implemented in reality, at least not in the short to medium term (Jacobsen 2008). In the Philippines, the number of women involved in formal and informal political institutions has increased, and several women have become leaders and held strategic positions. Research by Rallonza (2005), however, has shown that female legislators in this country have not been effective as agents of social change because they have been constrained by strict party discipline. According to Rallonza, the party affiliation system means that individual legislators cannot introduce issues into the political agenda because they are bound by their party's platform and traditional orientation on gender issues, such as the roles of women and men in the family.

A similar situation has been observed in Sri Lanka and Indonesia. Sri Lanka was the first Asian nation to have a woman Prime Minister, Sirima Bandaranaike, who was elected in 1960. In 1994, her daughter Chandrika Bandaranaike Kumaratungga became Prime Minister. It is also worth noting that Kumaratungga's father, SWRD Bandaranaike, served as Prime Minister and her grandfather was chief advisor to the British colonial government before Sri Lanka achieved independence. According to Attanayake (2003), the existence of these two female political leaders in Sri Lanka seems to suggest that women's participation in politics is comparable to men's. However, Sri Lanka has a small number of women in national and local parliaments, making up less than 5\% of all legislators and the parliamentary female-to-male ratio is 0.061 or only about 6\% (Inter-Parliamentary Union 2014).

Indonesia has had a female president, Megawati Soekarno Putri, who was elected in 2001. It has been suggested by some observers that Megawati's political success is largely attributable to the fact that her father was Indonesia's first president, Soekarno. She had little political capital of her own and her presidency might be characterized as passive (Kingsbury 2005). During her term in office some observers and women's organisations believed that a female president 
would pay more attention to women's issues. It seems the election of a woman as president of Indonesia did not have much influence on women politicians who might have wanted to run for political office. This might have been because the concept of a female leader, especially a president, may remain contentious among politicians, religious scholars, intellectuals and feminists in Indonesia (Wichelen 2006). Wichelen suggests that, in Indonesia, which has the largest Muslim population in the world ( $88 \%$ of 241 million people or about 212 million Muslims (Population Reference Bureau 2013)), some groups felt uncertain about whether a female leader was deserving and capable of leading the country. Moreover, the leadership style of this particular female president tended towards keeping a low profile, a lack of political ideology, and an unclear position toward the military (Beittinger-Lee 2009). This may have contributed to distrust of her leadership. This leadership style did not appear to influence and inspire women who may have wanted to run for political office in Indonesia. This can be seen through the differences in opinion among some women's activists in Indonesia about Megawati. As president in 2003, she undervalued the efforts of some activists to ratify the $30 \%$ quota system for women politicians. In this, she was seen as not representing the interests of women in the Indonesian political context (Diani 2014). In this case, the example of a female president had little impact on representation in local and national parliaments.

The number of female legislators in Indonesia remains low and has yet to reach the desired 30\% considered ideal (Karam 1999b; Venny 2010). At present, even though gender equity provisions for representation in the parliament have been fully implemented, the Inter-Parliamentary Union (2014) reports that women comprise about $16.8 \%$ of legislators in Indonesia. Nonetheless, the number of female legislators more than doubled from 1999 to 2009 after the establishment of the quota, and it has been suggested that there were other factors that contributed to this phenomenon including a significant incumbency effect (ShairRosenfield 2012). 
In several Asian countries such as South East and South Asia, some women who have been successful in high level politics have been able to draw on family background as discussed above although there are also female political leaders who do not come from political families. In the west, such connections exist (for example, the Kennedy family in the United States), but many female politicians do not come from this kind of background. This is an interesting aspect of political participation in some parts of the world and is very much a reflection of specific social and cultural factors that may affect women's decisions to enter politics as well as voters' choices during elections.

Review of the literature suggests that the research on women's political participation and representation cannot be only seen separately in terms of political structures and the personal situation of women politicians themselves. As is the case with many social phenomena political participation likely depends on a number of related factors whose relative importance may vary from location to location and case to case. However, the desirability of having more women in positions of political authority seems to be increasingly agreed upon around the world. This is perhaps recognition of the importance of the views of the whole population regardless of gender and the specific social and political context.

Despite the fact that different countries have different policies that affect women's political participation as well as different norms, religious traditions, and social, economic, and political structures, most countries share patriarchal traditions that have the potential to influence political participation. In this study, this common aspect of the social cultural environment that may shape women's political participation is significantly different from other areas in Indonesia as well as elsewhere in the world. The province of West Sumatra is dominated by an ethnic group, the Minangkabau that maintains a matrilineal social system. The relevant cultural and social factors then, take on greater importance in this study as the political participation of women in a matrilineal system has not been studied before. An understanding of women's political behaviour in this context may 
provide important insights into the context of politics seen from the perspective of gender.

Gender studies provide a perspective on a range of issues such as women's movements, women's agency, women in NGO and civil society and also women in politics and legislatures (Celis et al. 2008). Considerable research concerns women's representation in parliament that has typically been viewed through the lens of patriarchal structures. In this study however, the aim of the research is to describe, explore and analyse women's experiences as candidates in an area where a matrilineal society should provide opportunities for more women to be involved in politics. Moreover, the view of people in this society where the matrilineal structure of society affects their daily life, may be significantly different from other parts of the world. These views and opinions are particularly interesting because it has been suggested that matriarchal societies are based on consensus and egalitarianism (Goettner-Abendroth 2012). Thus, whether or not egalitarianism is a central philosophy of this West Sumatran matrilineal society will be explored in more detail in this study along with the ways in which it might affect the participation of women in politics.

\subsection{Democracy}

Political representation is an integral part of a democratic system. One of the most comprehensive discussions of representation is that of Pitkin (1967) which identifies four views of this phenomenon: formalistic representation that encompasses authorisation and accountability and relates to the institutional set up for representation of public interests; symbolic representation which relates to how the representative stands for the individuals he or she represents; descriptive representation which is the way in which the representative resembles the people he or she represents; and substantive representation which is the action taken by the representative on behalf of the people he or she represents. In particular, substantive representation has been of concern in connection with female politicians and female members of the public because of the view that women 
should be more attentive to the needs and interests of other women than male politicians (see, for example, Celis et al. 2008; Mansbridge 1999).

Under a democratic system every group in society to some extent is entitled to representation. While it might be argued that women's interests can be represented by male politicians, it is widely assumed that women would more effectively represent the interests of their own sex because they share the gender experience of their female constituency (Paxton, Hughes \& Painter 2009). The institutional aspects of representation will be significant in this respect as well because they have been seen to advantage certain groups at the expense of others. Williams (1998), for example, considers the experience of women in the United States from the assumption that groups that have experienced historical disadvantage require a way to express their need in the deliberative body of a nation as an aspect of equal citizenship.

The implementation of democratic systems in some places seems to be paradoxical in giving opportunities for women in politics. This can be seen through the way such systems give opportunities to every person (including women) to be active in politics in theory but, in practice, there may be considerable and real impediments to participation. Sartori (in Stockemer 2009, p. 430) notes that to be a democratic state means that a nation must guarantee that every person has political freedoms, individual civil liberties, human rights and the rule of law. Diamond (1999) suggests that democracy, by nature, consists of two parts: the electoral democracy and the liberal democracy. These two aspects of democracy are echoed in a definition of democracy that recognizes two forms, namely procedural democracy and essential democracy (Haris 2007). In this understanding, procedural democracy is similar to electoral democracy and encompasses several freedoms; freedom of the press, of organisation, of assembly and of speech. Procedural democracy at least has six components that are required for its function. They are political parties, elections, parliament, executive branch, judicial branch, and freedom of the press. Since the procedural aspect of 
democracy relates to elections which should be free and fair (Stockemer 2011), this should extend to equal opportunities for women to participate and take positions on issues of interest to them and also to have access to information and the ability to form groups to further their interests (Molyneux 2002). All of these aspects of democratic systems are generally assumed to support greater participation in politics by women.

Representation of and by women is integral to the electoral process which represents the focus of this research and relates to the concept of 'inclusiveness.' O'Donnell, Cullel and Lazzeta (2004) describe the inclusiveness of democracy as the ability of all citizens, who are legally entitled to vote and to be elected to office, to participate in the process of making society-level decisions. In many cases however, women experience what is often referred to as a gender bias against them which generally derives from longstanding cultural and social norms that relate to women's traditional activities (Lawless \& Fox 2005). Views of this kind hold that women are excluded from or limited in their political participation based solely on their social roles in spheres other than politics.

A number of studies (Karam 1999b; Karam \& Ballington 2005; Lovenduski \& Karam 2002) have suggested that more women in parliament would lead to the passage of more policies relating to women's issues. However, other studies on women's representation and political participation indicate that there is no guarantee that female legislators will focus on women's issues (Iwanaga 2008). This may be because party policy and the political systems influence the role legislators of either gender can play in parliament. Political decisions are heavily influenced by circumstances and female politicians are likely to be influenced by the political environment as well as by their experience as women in society (Iwanaga 2008).

For every individual with political aspirations, including women in most societies, political participation requires affiliation with one political party. Political parties act as an instrument of democracy and the vehicle by which 
individuals gain access to the public sphere (Bennet 2009). Bennett (2009) further suggests that in many systems however, political parties exert control over who can enter their ranks and what issues those individuals will focus on. In this way, parties play a significant role in who can enter politics and what their official actions will be once they do. In other words, he concludes, the party has full power over its members in deciding who will represent the party in government. This is an aspect of the party system that may affect a politician's ability to influence the political agenda beyond the party line and may, in the case of women, contribute to difficulty in bringing women's issues into the political forum.

The growth in political participation by women, then, can be seen as a new or added dimension of democracy (Paxton, Hughes \& Painter 2009). They suggest that democracy has two dimensions. The first of these is a political right which holds that a government, that has been chosen through a meaningful process of election and has political parties that compete for political power, is legitimate. This type of situation may allow women to compete more effectively in terms of opportunities and the transparency of such systems may also facilitate their path to political office. Second, the status of civil liberties in a democratic system may allow individuals to express their political opinion and to organize and participate in any political group. This may allow women to be involved in the public sphere as part of organisations, parties and charities.

Phillips (1998) and Dovi (2007) suggest the importance of democracy for women who are involved with and participate in politics is that democracy can facilitate representation of women in parliament. Their argument centres on a number of points; 1) women politicians may be role models for female candidates and increase their confidence in political institutions; 2) equal representation of male and female politicians shows justice and equality; 3) most women tend to be concerned with the things usually known as women's issues and 4) the 
representation of women in parliament is a sign of a revitalized democracy and increases the legitimacy of democratic institutions (Dovi 2007; Phillips 1998 ).

From this, it seems likely that the nature of democratic systems and women's participation within these systems will result in higher numbers of women in political office in democratic than in non-democratic states. Nonetheless, Stockemer (2009) presents a contrasting finding noting that, whether or not women's participation tends to increase with the maturity of a democracy, the nature of democracy does not appear to affect the numbers of women in elected office. The evidence thus suggests that democratic political systems should provide more opportunities for women to participate in the political process and serve in elected office. In a democratic system, theoretically, laws are gender neutral and the government facilitates the participation of every eligible citizen including women but in practice, many factors may act as obstacles to including women in politics (Paxton \& Hughes 2007). Despite this procedural equity, democratic systems cannot guarantee that more women will serve in office than in other kinds of political systems. Other factors, such as culture and the social structure of society also play an important role in determining political participation.

This study focuses on the political participation of women in the matrilineal society of West Sumatra. The Minangkabau culture native to the area views itself as embodying principles of egalitarianism and opportunity that parallel those of western democratic systems. In addition, women play a central role in traditional society including in its leadership. It is for this reason that the experience of women in the political arena in this part of Indonesia is interesting. Their cultural and social experience as members of society is very different from that of women in most other parts of the world and there may be significant impacts on their political experience as well. 


\subsection{Culture and Matrilineal Society}

Generally, the study of female politicians in the West Sumatran matrilineal system can be seen as a case study of how culture affects women in politics. Culture refers to the universal human capacity to classify, codify and communicate experiences symbolically. Using Taylor's (1924) definition as a starting point, culture can be thought of as "a complex whole which includes knowledge, beliefs, customs, traditions, behaviours, language, art, morals, norms, law, religion, and any other capabilities and habits acquired by members of a society" Taylor (1924, p. 1). According to Ross (2009), culture is important in politics since it can provide a framework for understanding the political actions of individuals. Paxton and Hughes (2007) note that culture may help explain women's exclusion from politics in the past and the barriers they face in attaining power in the present. In this sense, culture can be viewed as an analytic tool to study women's participation in politics.

Most societies in the world have cultural values that accord more opportunities to men. In patriarchal societies, male dominance refers to the situation in which men possess the power to physically control women (Reiter 1975). In West Sumatra, the society possesses cultural values in which women hold important positions. Its members perceive egalitarianism to be a prominent feature of their culture and feel that individual competence is recognized and based on a person's achievements and capabilities. Several western studies on matrilinealism in this region recognize that senior women in a clan are an important part of the leadership structure in Minangkabau communities (Blackwood 2000).

Senior women and men are leaders in their communities where they are part of a complex 'web of power' with many different orientations (Blackwood, 2000, p.189). According to Blackwood, under adat, all women and men have specific and clearly delineated rights and privileges, based on their sex, age, and birth order. This can be seen in the roles of men and women which include the position 
of women as mothers of the lineage, while men are supposed to protect the lineage.

Reenen (2006) suggests that senior women are 'as the pillars of the house.' That is, women's roles as mothers, sisters and also wives give them a certain level of agency and allow them to remain strong even as the Minangkabau community changes in response to global conditions. An important aspect of their role is to maintain traditional culture. One of the central aspects of this is the desire to continue the family and to ensure that descendants remain within the Minangkabau system. For example, Elfira (2010) notes that Minangkabau women tend to prefer their sons to marry a Minangkabau woman, rather than a woman from another ethnic group because ethnicity follows the mother's line, and a daughter-in-law from another group will have children who are not seen as Minangkabau. These children will not have a clan identity (suku) and hence will have no place in the traditional social structure. This type of concern among older women is part of their status as Bundo Kanduang (True Mothers) and exemplifies concern for their family and its future.

Wierenga (1995) notes that women in Minangkabau society have social status accorded to them by custom through property ownership, and as a consequence of egalitarianism in the society. Thus, with these privileges, it might be assumed that women in West Sumatran society have more opportunities to act in the public sphere, including in political participation and representation.

Studies on matrilineal systems in various parts of the world often make use of the term 'matriarchy'. Goettner-Abendroth (2012, p. xvi) suggests that matriarchy is not a female equivalent of patriarchy. She notes that matriarchy derives from the word for mother and 'arche'. The Greek word 'arche' means not only 'domination' but also 'beginning', thus matriarchy denotes 'mothers from the beginning'. According to Goettner-Abendroth, this refers to the biological fact that through giving birth, mothers engender the beginning of life and acknowledges the cultural 'fact' that they also created the beginnings of culture 
itself. She also discusses and analyses various matriarchal cultures around the world using critical analysis and cross-cultural approaches as well as anthropological, ethnographic and historical research techniques. Some of the matriarchal societies that have been compared using these means include the traditional cultures of Mosuo in Southwest China, the traditional culture of Minangkabau in West Sumatra, the traditional culture of Khasi and Garo in Meghalaya India, the traditional culture of the Akan peoples in Africa and the traditional culture of the Iroquoian peoples of North America. Most matriarchal societies have small populations, are marginalized and are almost extinct since, in the modern context, they are surrounded by dominating patriarchal systems. The Minangkabau are the largest modern group of this type today.

Unlike Goettner-Abendroth, most anthropologists believe that the terms 'matriarchy' and 'patriarchy' come from Greek and Latin roots where 'archon' means 'rule.' For this reason, the terms matriarchy can be understood as meaning 'rule by mothers.' In West Sumatra, however, women are not leaders, despite their status as Bundo Kanduang. Women have a significant and important role but do not govern the society. While the terms matriarchy and matriarchal are often used to refer to non-patriarchal societies, this thesis refers to Minangkabau society in West Sumatra as a matrilineal society; in recognition of descent and transmission of property through the maternal line.

Goettner-Abendroth (2012) suggests that matriarchal societies have four levels of social patterns that include the economic level, social level, political level and spiritual-cultural level. The economic level relates to how women in these societies have control of resource production such as fields and food and especially goods or property that are controlled by clan mothers. Women manage and distribute property equally among the children and grandchildren in their clan and economic structures are based on economic mutuality and circulation of gifts. She explains that wealthy clans may be responsible for conducting village festivities and are often obligated to distribute their wealth to the people in their 
village. This suggests that such societies maintain principles of equality and reciprocity.

Second, at the social level, women in these societies may live together in clans based on kinship ties that are characterized by matrilineality and matrilocality. Matrilineality means that the clan's property, titles and social position are passed down the maternal line. Matrilocality means the clan may live in one communal house and that marriage takes place among clans in which women live permanently in the communal dwelling while husbands may visit the house only at night, leaving in the morning to return to their mother's or clan's house. This kind of visiting marriage often results in people in one location being related to everyone else by birth or marriage. According to Goettner-Abendroth, this suggests that matriarchal societies are based on kinship, within a framework of gender equality and are non-hierarchical.

Third, at the political level, matriarchal societies may be societies of consensus. Women and men may gather in the communal home to discuss domestic matters. In these meetings all members of the clan (men and women) may contribute and give their opinions. The decisions are made by consensus. Similar consensus also occurs at the village level. When everyone in the village needs to discuss something, delegates from different clans may meet as a village council and voice their interests. Decisions may be based on a consensus of the delegates of the clans. Goettner-Abendroth defines this arrangement as an egalitarian society of consensus.

Fourth, at the cultural and spiritual level, Goettner-Abendroth notes that such societies may consider the world holy and believe that it should be protected and loved. These spiritual attitudes suggest the whole world is divine and may engender the sacred culture.

The characteristics of Minangkabau society are not exactly the same as those described by Goettner-Abendroth (2012). For example, visiting marriage is no 
longer the norm. Matrilocality is also becoming less common than in the past as people shift to nuclear family arrangements in the modern context. Members of the Minangkabau ethnic group have experienced a great deal of social change over time with one of the most important features being the adoption of Islam. Islamic teachings have become part of their way of life and have contributed to change in the matrilineal structure of the community.

A review of the literature suggests that culture may be a key element in understanding women's activities in the public space, including in politics. While many cultures around the world have a patriarchal structure, matriarchal societies give privileged status to women that may facilitate their participation in politics by providing a central role for women in the traditional administration of the society and its institutions. This can be seen as parallel to political office in the modern context, as elected officials are responsible for the administration of modern institutions. In the case of culture in Minangkabau with its matrilineal system, it seems likely that women would have the opportunity to engage in a variety of modern activities outside the home because such activities already existed in the traditional context. The Minangkabau culture allows for such activities where women are involved in traditional events such as participating in decision making for the extended family and in ceremonies, such as weddings and other life course events.

How the matrilineal system in West Sumatra affects women's experience in politics may be visible during their candidacy for public office. It might be expected that some of the status conferred to women by the matrilineal system extends to the modern political arena and acts as a benefit to them in running for office. However, as West Sumatra is one of 33 Indonesian provinces, its internal political system is influenced by and cannot be separated from the political system of Indonesia. 


\subsection{Women's Representation in the Indonesian Political System}

Women have experienced a long history of political involvement in Indonesia. They were involved in the nationalist independence movement during the colonial period and have had the right to vote since the first election in 1955 with more women voting than men (Martyn 2005). Nonetheless, this involvement over several decades has not led to an increase in the number of women in Indonesian government even in the two most recent elections which occurred during a period of significant social and political change (Venny 2010).

Women's political participation in Indonesia can also be seen in the activities of women's movements. In Indonesia, the women's movement held it first nationwide congress on 22-25 December 1928. At this time, 30 women's organisations met to discuss women's issues including marriage law, polygamy and women's education, and also political rights (Vreede-de Stuers 2008). At this congress, there was a greater focus on social issues than political issues. In Indonesia, women's organisations and women's movements that have existed prior to Indonesian independence, did not have much effect on women in politics after Indonesia gained Independence.

During the colonial era, the activities of women's organisations were intended to educate and empower woman. To some extent, this included involvement in the nationalist movement. However this involvement did not have much effect on women in politics after Indonesia gained Independence. Blackburn (2004) suggests that, in the early democratic period from 1949-1958, women's organisations flourished and included groups like Perwari, Kowani and Gerwani which were independent and not especially state oriented (p.23). In the Guided Democracy era from 1958-1965 under the Soekarno government, women's organisations were required to contribute to a nationalist solidarity which had a negative impact on the Gerwani organisation. 
The motherhood program during the Soeharto era placed women in a subordinate position: private space was considered appropriate for women while public space was for men. This was viewed as representing equality because men and women, who had different social roles, each had a sphere of activity (Stivens, 1991; Robinson, 2009). This dichotomy resulted in a gender ideology that was reinforced by development programs where women were expected to support and serve their family, husband and the state while men worked outside the home. In this way, the state constrained women's activities in the public space. While women's organisations continued to exist, their role during the Soeharto era was limited to activities that fit the current ideology. This ideology has been called 'state ibuism'. 'Ibu' means 'mother' in Indonesian and the term refers to a situation where the role of women's organisations was officially seen to be encouraging a situation where women were dependent on their husband and other men politically and structurally, despite their very high representation in the professions and in paid work (Suryakusumah 2004).

Since the end of the New Order government in 1998 and in order to modernise the political system, the government created an affirmative action program for women with a 30\% quota - because this was the international norm - to increase the number of female legislators in national and local parliament in the 33 provinces of Indonesia. This policy was introduced in the 2004 election and used a $30 \%$ quota because this value was used internationally (Bylesjoe \& Seda 2006; Dahlerup 2005).

Affirmative action for women as manifested by the $30 \%$ quota policy was incorporated into Indonesian Electoral Laws in the 2004 and 2009 elections (Puskapol UI 2011). Law No. 8/2012, article 55 states that: "The list of candidates referred to in Article 53 must include a minimum representation of at least 30\% women".

Law No 8/2012 article 58 (3) states : "The regional electoral commissions must verify that the documents relating to administrative requirements for legislative 
candidates are complete and correct, including the fulfilment of the requirement that a minimum of $30 \%$ of candidates be women".

This law provides opportunities for women to be involved in the election process and to be elected as legislators. It mirrors concepts the Indonesian government has already implemented in establishing democracy where women have the same rights as men, namely the right to vote and the right to stand for election (Shvedova 2005). Nonetheless, this regulation is just a recommendation without strong legal enforcement from the Indonesian government that can compel real involvement of women in politics (Sitasari 2007).

Through this policy female politicians seem to have a pathway to win seats in parliament but several barriers remain. Their numbers in parliament still have not reached the $30 \%$ goal for women legislators and one important reason for this is because of the patriarchal culture practiced not only by men but also by women (Venny 2010). Although the form of women's political participation in Indonesia can be seen historically through the involvement of women in the national movement for independence, after 1945 they seem to have remained in a subordinate position in the political arena (Wierenga 2001). Interestingly, the major argument against quotas for women in Indonesian politics has been based on the idea that there are not enough qualified potential candidates available (Bylesjoe \& Seda 2006).

Even though the parties act as their 'vehicle' to parliament that gives women opportunities for candidacy to be elected and have a seat in the parliament, female politicians in Indonesia have not achieved the 30\% level suggested by the law. This is because to date, political parties have not been required to implement affirmative action policies, only encouraged to do so. The Political Parties Law was enacted prior to the 2004 and 2009 elections (regulation number 31/2002 and 2/2008), but political parties have not been penalized for not complying and have few obligations to engage in affirmative action (Puskapol UI 2010). In the Indonesian political system this affirmative action policy has been called 'a 
rubber law' without consequences for those parties that do not obey it (Venny 2010). Another aspect of this type of party behaviour has been attributed to the fact that the women's movement has not been successful in lobbying political elites and party leadership to gain support for ideals of social justice and democracy (Hoodfar \& Tajali 2011).

Review of the literature suggests that changes to the political system in the Reform Era and under regional autonomy that were implemented in Indonesia after the fall of the Soeharto government in 1998 have not significantly changed the situation of women in politics. The regional autonomy system created significant opportunities for local provincial governments to exert their authority (Sarundajang 2001), but in practice, the number of women in local politics is still low (KPU 2009). The domination of a patriarchal culture in the Indonesian political system seems to be an important factor that affects the involvement of women in politics. For this reason, examination of the matrilineal system of West Sumatra and the experiences of women politicians in that region may provide important insights into the nature of culture in influencing the political participation of women in the Indonesian context.

\subsection{Conceptual Framework}

Norris (1993) and Matland (2005) have developed models of political recruitment that describe how individual citizens may become politicians. They note that women who want to participate in politics need to pass three critical barriers including 'making a decision to run for office, being selected as a candidate and being elected by voters' (Paxton \& Hughes 2007, p. 102). The decision to run for office comes from the individual (him or herself); the person needs to decide to run for office. At this point, women must be eligible to run for office and must wish to hold a seat in parliament and to be an agent for the community. The second step is to be selected as a candidate by a party. At this stage, women must aspire to hold political office and fulfil the party's requirements and preferences. Finally as candidates, women need to be chosen by voters to represent their needs 
and then to become legislators. In West Sumatra, women in politics must undergo this process as outlined by Norris and Matland but are also influenced by the dynamics of local politics as well as the matrilineal culture in this area.

This recruitment model in politics parallels the concept of supply (see Paxton \& Hughes 2007) and is related to culture and societal structures. Women politicians may be affected by the ideas, beliefs and attitudes current in their society. Women's motivations (interest and ambitions) to become involved in politics can be explained in the frame of the culture where the individuals in question are living. For example, a society with a norm that suggests women should stay at home may result in women tending to have less motivation to run for office. In terms of the structural perspective, money, time, civic skills, education, work and economic power are most often seen as resources for political participation (Krook 2010; Norris \& Lovenduski 1995). These cultural and social structures are interrelated and may affect women in politics. Further, Ross (2009) notes that culture in public, shared meaning, behaviours, institutions and the social structure cannot be understood as culture itself but form culturally-defined phenomena (p.45).

Since resources including energy, time, money, skill and experience may be influential factors in the political arena, this means that women who decide to run for office must be educated and have the capabilities seen as relevant in their local context and must improve their electability in the eyes of the voters. With regard to capabilities, Nussbaum (2011, pp. 20-1) defines this concept as: "The ability of individuals in creating substantive freedom to achieve alternative functioning combination; in other words, they are not just abilities residing inside a person but also the freedom or opportunities created by a combination of personal abilities and the political, social, and economic environment".

Nussbaum distinguishes 'personal and combined capabilities'. Personal capabilities relate to characteristics of personality and character which may include useful skills, intellectual ability and emotional capacities. Combined 
capabilities refer to the development of personal capabilities through interaction with the social, economic, familial and political environment supported by the individual's personal capabilities. In other words, social structure, culture and government provide opportunities that the individual can use to the extent that his or her personal attributes, as developed through interactions in the environment, allow. In the context of this research, the traditional matrilineal culture in West Sumatra seems likely to privilege women by giving them opportunities to manage their communal property and be involved in public cultural events. For this reason, women who want to run for political office and then become legislators should be able to use their social status in combination with their developed individual capabilities to achieve their political ambitions.

Participation in politics is, at some level, associated with the power to influence policy, governance, and various aspects of the public sphere. Lukes (1974) suggests that power has three dimensions. The first of these is the ability to overcome conflict over political preferences openly. The second dimension is the ability to prevent the preferences of others from reaching the agenda. In this context, a politician might achieve his or her goal by taking preventive action to avoid any possibilities that would lessen their chances of success. The third dimension involves shaping the preferences of others to match the politician's own goals. This might involve attempting to control the political agenda in terms of issues and potential issues that could be latent or lead to conflict. These three dimensions of power can be seen in the form of power relations in any given political system (Paxton \& Hughes 2007).

In line with the three dimensions of power, women politicians can affect social structure through their decision making power and position in office. This has been seen as both the motivation for women to take part in politics and also the rationale for encouraging them to do so. Paxton and Hughes (2007) note that women must be involved in politics because politics is the main means for making decisions at the societal level. Access to these channels by women means that the 
democratic goal of representation for all strata of society is more likely to be achieved and potential marginalization of half the population can be avoided.

The second step for women who wish to gain political office is becoming a candidate. This means that women have to be selected by political elites. This relates to the concept of demand. The preferences of political parties and their elites are critical and determine the pathway for women running for political office.

After this, to become a legislator, a woman candidate must be elected by voters. In this case, how voters choose who to vote for is often related to their political knowledge and their social and cultural background. As suggested by Milner (2002), it is necessary to understand the level of political knowledge or civic literacy of a community in order to understand the nature of political participation in that location. In this study, voters, not just candidates, are expected to be affected by their matrilineal background and its social and cultural views. Similarly, such views colour the attitudes of community leaders whose perceptions may serve to reinforce the attitudes of members of the community who look to them for guidance.

A measure of women's political participation is their success in gaining legislative seats. Norris and Lovenduski (1995) describe three explanatory models of political representation. First, representation can be seen as a symbolic concept in which the representational element is a concrete embodiment of an abstract identity, such as the Queen representing the state. Second, representation can be viewed as delegation; members of parliament as legislators, represent their constituents and have a duty to protect and promote their constituents' interests. This has traditionally been termed the 'trustee' model of representation, as espoused by the conservative thinker, Edmund Burke (Rosenthal 1998). Finally, representation can be viewed demographically; that is, legislatures are scaleddown reflections of the societies from which they are drawn. This is sometimes called, the 'mirror' theory of representation (Norris \& Lovenduski, 1995). 
In the context of West Sumatra, each of the three models has relevance for the participation of women in the modern political context. From the point of view of symbolism, women already have a symbolic status embodied in the concept of Bundo Kanduang in Minangkabau society. As leaders in the traditional context, it may be the case that this status granted to them traditionally can be transferred to the modern context. In terms of delegation, women in Minangkabau society have the responsibility to represent the interests of their nuclear and extended family and clan in the broader context. This status parallels the role of the politician in the modern context, except that the constituents a politician represents are drawn from society at large and are not limited to those with whom the legislator has a personal connection as in the traditional extended family. Nonetheless, in Minangkabau society this role is one naturally ascribed to women. Finally, in the demographic dimension, women in Minangkabau society represent half the population, as they do elsewhere in the world. For this reason, again as elsewhere, they might be expected to represent the views and interests of others like themselves, which may be distinguished by gender as well as by other attributes.

\subsection{Summary}

This chapter reviewed the significant literature for this study. The first section described the phenomenon of women's political participation and representation in general around the world; the second outlined the nature of democracy and the role of political parties in terms of giving opportunities to women in politics. The third section provided an overview of matriarchal societies across the globe and through the lens of political culture more broadly. The fourth outlined the nature of the Indonesian political system and its likely impact on the election of more women in politics. Finally, the conceptual framework for this study was discussed. 
The literature discussed here provides the theoretical background for this study. Additional literature on the contextual background of the research is discussed in Chapter 3. 


\section{Chapter 3}

\section{Context and Background}

This chapter describes the background and contextual setting of this study. It discusses the location of the study, the characteristics of matrilineal society in West Sumatra including the nature of ancestral property, kinship levels, Minangkabau leadership, adat, philosophy and religion. It explains the values members of the society see in their matrilineal system such as progress and development. The characteristics of West Sumatra as a province and recent developments relevant to this study are also considered. It should be noted that the proverbs and their translations that are used in this chapter were taken from Fanany and Fanany (2003).

\subsection{Geography and Physical Characteristics}

The province of West Sumatra is inhabited mostly by members of the Minangkabau ethnic group. It is one of 33 provinces in Indonesia. This province is situated in the western part of the island of Sumatra and is bordered by the Indian Ocean on the west side, by the Bukit Barisan Mountains along its border with the province of Jambi on the east side, the province of Bengkulu on the south, and the province of North Sumatra on the north side. West Sumatra is the traditional Minangkabau homeland. Historically the Minangkabau world, called 'alam Minangkabau' in the Minang language, is divided into two: the highland and the coastal areas. The highland is called darek and is surrounded by two mountains. It is hilly and a region with fertile soil and cooler temperatures. The coastal area beyond the darek is called rantau (Naim 1987). Rantau is the generic term given to the destination of Minangkabau people (especially young men) who participate in a tradition of temporary migration where they leave their original area (darek) to go to other areas in order to seek wealth, knowledge and experience (Kato 1978; Naim 1985). Padang, the capital city of West Sumatra is part of the rantau and other parts of the rantau include Pesisir Selatan, Solok and Sawahlunto Sijunjung, also in West Sumatra. The darek, which is commonly 
mentioned in adat and traditional literature, consists of three regions that are called luhak nan tigo; Luhak Tanah Data, Luhak Agam, and Luhak Lima Puluh Kota. In contemporary Minangkabau society, these three luhak make up the modern regencies (kabupaten) of Tanah Datar, Agam and Lima Puluh Kota.

At present, the three luhak still figure prominently in the context of adat and customs. The phrase, 'return to the nagari' (kembali ke nagari) has appeared since the Reform Era began in 1998 (Fanany 2003). The nagari was traditionally the lowest division of administration in West Sumatra. The nagari preceded the imposition of a national administration system during the New Order, but interest in these historic divisions of Minangkabau territory has grown since regional autonomy along with a nationwide intensification of ethnic identity (BendaBeckmann \& Benda-Beckmann 2009). The nagari exist as an older spatial organisation that has been overlaid by the administrative divisions of modern Indonesia.

The modern administrative structure in West Sumatra includes seven municipalities and 12 regencies, each with its own legislature, elected every five years at the same time for the national and local parliaments. The legislature at the provincial level represents people in the province, municipalities and regencies. The legislature at the municipality and regency level represents people in each municipality and regency. For this study, data on women in politics in West Sumatra were collected based on the number of female politicians who represent five municipalities and regencies that also correspond to the darek and rantau regions in three luhak.

\subsection{Characteristics of the Matrilineal System}

The Minangkabau ethnic group of West Sumatra is the largest community in the world at the present time with a matrilineal system (Evers 1975; GoettnerAbendroth 2012; Indrizal 2004; Kato 1978; Nasroen 1971). This ethnic group has its own system of customs or traditional law that is called adat. People's social 
structures, behaviour, and way of life as Minangkabau are determined by adat which dictates four main aspects of the social context. These four aspects include how communal property will be inherited (the economic aspect), what type of settlement and lineage or kinship levels are important (social structure), who is entitled to lead the clan (politics), and all things related to culture, including exogamy, the nature of the community and how possessions are to be distributed (Thaib 2011).

\subsubsection{Ancestral Property}

Property is divided into two categories, ancestral property (harta pusaka) and self-earned property (harta pencarian). Assets such as land and agricultural land, traditional houses and fishponds are categorized as ancestral property. This ancestral property remains in the female line passing to female descendants, from a grandmother to her daughters and granddaughters. Nonetheless these assets can be used by all members of the extended family in one clan under the leadership of the head of the clan and also based on agreement among the senior women (Bundo Kanduang) in the clan. By contrast, self-earned assets are obtained by a man or woman as a result of their work or occupation. This property goes to the children in their nuclear family. If the marriage ends in divorce, the property is retained by whoever earned it (Fanany 1997; Navis 1984).

To date, the matrilineal society still has a substantial impact on Minangkabau society. Specifically, the system of ancestral communal property may give women the possibility of using property as a safety net to protect them and their children from economic vulnerability in the case of the dissolution of a marriage (Fanany 1997). To some extent, it also can be assumed that there is a possible connection between ancestral properties and women's political participation since these properties may be utilized for social activities, even in politics. Nonetheless, the mamak, or maternal uncle, still has a significant role as leader of the clan members, or at least as tungganai (mamak rumah) at a lower level, ensuring that the ancestral lands are passed on based on the maternal line (Ilyas 2006). Senior 
women maintain the responsibility of managing and overseeing the use of and production from ancestral property, of supervising the household and the education of the children, and of giving their opinions and being involved in important decisions within the community. In recognition of these roles, the older women are called 'true mothers' or Bundo Kanduang and this is the reason women are seen as the core of the extended family (Indrizal 2004; Sanday 2002).

Bundo Kanduang (true mother) is described as a good mother and strong leader within the family and community. Bundo Kanduang can be seen as epitomizing of the ideal for the older, wise women, who uphold the dignity of women generally in the society. As a true mother, the power of Bundo Kanduang is greater than the Datuk Penghulu, a role played by men, because she is the mother of Datuk Penghulu themselves (Abidin 2011). Further, Hakimy (1978) suggests that this traditional importance of Bundo Kanduang is reflected in literature, in adat and in the community's views. The place of Bundo Kanduang in Minangkabau society is explained as follows:

Bundo Kanduang limpapeh rumah nan gadang, umbun puruak pegangan kunci, umbun puruak aluang bunian, pusek jalo kumpulan tali, sumarak dalam kampuang, hiasan dalam nagari, nan gadang basa batuah, kok pai tampek batanyo, kok pulang tampek babarito, kok hiduik tampek banasa, kok mati tampek baniaik, kaunduang-unduang $k a$ Madinah, payuang panji $k a$ sarugo.

Bundo Kanduang is the butterfly of the big house that holds the keys to wealth, is the top of the net and the spool that holds the string, is the centre of people in the village, is an ornament for the state, and is revered. While going out, she is the place for asking, when come back, she is the place to share the news, while she lives, you can swear by her name. When she's dead you vow to her memory. She makes laws that cannot be changed. She is the cloth that will shelter you on the road to Medina and she is the umbrella that will shelter you on the way to Heaven (Fanany 1997). 
From the passage above, it can be seen that women in the matrilineal Minangkabau society have a particular social position that is traditionally defined. The important role of Bundo Kanduang is reflected in the traditional matrilinealism of that society and embodied in the principles of adat that still exist today in Minangkabau society. Most families seem to actively want daughters to maintain the matrilineal line, but children of both sexes tend to be socialized into the context of traditional gender roles from an early age with girls perhaps given chores to do around the house that allow them increasing responsibility for the day to day life of the family. Boys, by contrast, may be expected to participate in activities outside the home that are seen as male domains, often in the context of the local mosque or other community institutions. (Schrijvers \& Postel-Coster 1977).

\subsubsection{Kinship Levels}

There are three kinship levels in the West Sumatran matrilineal society that are referred to as samande or sapariuak, saparuik, and sasuku or sapayuang (Fanany 1997; Indrizal 2004; Kato 1978). The samande level is represented by the nuclear family. Children remain members of their mother's extended family throughout their life. This kinship arrangement is also referred to as sapariuak, meaning that members of family who come from the same mother eat together from one pot (pariuak). In the past, the nuclear family lived together in the traditional, multifamily dwelling, rumah gadang, but now nuclear families tend to live separately from their extended family. This is now more common in Minangkabau society, especially in situations where families or individuals have migrated to other areas. The second kinship level is saparuik which comes from the word paruik meaning womb that refers to the extended family, which consists of three generations. Traditionally, they also lived in one rumah gadang. The last kinship level is sasuku, sakaum or sapayuang; suku means clan where members are people who are saparuik and are related by blood or by adoption, following the matrilineal line. People with the same suku, kaum or payuang may share communal property transmitted in the female line (Fanany 1997; Indrizal 2004; Kato 1978). 
While heads of families at the nuclear and extended level of kinship are women, there are important leadership roles for men. The most significant of these is the mamak, or maternal uncle. Minangkabau men act as mamak to their sisters' children and play a major role in their education and socialisation. It should be noted that, because people remain part of their mother's family for life, the mamak is part of the same family as his sisters and their children. The children's father, however, is a member of his own mother's family where he retains traditional responsibilities for his own kamanakan (nieces and nephews) and towards the property belonging to his extended family. In the past, the role of the mamak was extremely significant, but it appears that this role may be losing importance largely because of modern living arrangements that separate extended family groups (Blackwood 1995).

As explained above, the kinship levels, the leaders of the family, and ancestral property arrangements based on the female line still exist. By contrast, living arrangements have changed from the extended family living together in one house to nuclear families living in modern-style homes. This change has also brought consequences for the relationship between mamak (maternal uncle) and kamanakan (nieces and nephews), where the role of mamak within nuclear families has been replaced by fathers. Kato (1978) suggests that continuity and change have existed side by side in this society and are visible in several characteristics of traditional Minangkabau customs. However, for most of history, change itself did not diminish the importance of the matrilineal system in West Sumatra. Similar to Kato, Afrizal (1996), in a study about matrilineal kin relations in contemporary Minangkabau society, found that the matrilineal social structure still has a strong impact on Minangkabau society. This impact can be seen in the positioning of women in the extended family. The importance of women's position and role within their extended family can be associated with women's political participation in this region. Nonetheless, rapid social change since the end of the New Order government has had an impact on traditional institutions, including the family. Concern for the future of traditional matrilineality in 
competition with the forces of globalization is widespread in West Sumatra. This may lead to even greater social change in the future (see, for example, Natin 2011; Sairin 2008; Uker \& Fanany 2011).

\subsubsection{Minangkabau Leadership}

Within the matrilineal system, the Minangkabau people see themselves as having egalitarian and democratic values. This can be observed in their community leadership which is referred to as 'tigo tungku sajarangan' meaning 'stoves necessarily come in threes' (Fanany 1997). This indicates that leadership is based on the functions of different leaders in Minangkabau society. These three kinds of leaders are adat leaders (niniak mamak which consist of penghulu, leaders of clans), religious leaders (alim ulama) and scholars (cadiak pandai). They are expected to work together to use their expertise to address any problems through consensus and consultation (Hadi 2009; Naim 2004).

Historically, the tripartite system existed since the earliest times when the Minangkabau still lived in their region of origin under their traditional social structure. The Minangkabau ethnic group developed various types of leadership in line with the social and political situation of this area. Thus, leadership in Minangkabau, which roughly corresponds to modern West Sumatra, has experienced several styles of leadership that can be divided into periods including ancient times, the colonial era, the post-independence era, and more recently the Reform Era.

Centuries ago, during the age of the Minangkabau Kingdom and the arrival of Islam, the Minangkabau people did not practice authoritarian rule. This can be seen in their community leadership and representation which had the three part system described above. The tripartite leadership was embodied in a set of kings, the king of adat (Rajo Adat), the king of nature (Rajo Alam) and the king of worship (Rajo Ibadat). Each had a different function and was respected by the public. The Raja Adat had jurisdiction over everything related to customs (adat), while the Raja Ibadat dealt with religious (Islamic) issues. These leaders were 
not viewed as infallible however (Naim 2004). Among the three, the King of Nature (Rajo Alam) had the highest status, and historically, according to legend, had been a woman called Bundo Kanduang, or the True mothers. Women do not seem to have ever served as the other two kinds of leader.

Even though the Rajo Alam ruled the Kingdom, he was not an absolute leader and was only slightly higher in status than the people. This is described in the proverb: "Pemimpin didahulukan selangkah, ditinggikan seranting" (The leader is put one step ahead, one twig higher). People tended to respect their leaders, as indicated by the proverb; "Kamanakan barajo ka Mamak, Mamak barajo ka Penghulu, Penghulu barajo ka nan bana, nan bana badiri dengan sendirinyo" (The nephew defers to the uncle, uncle defers to the clan leader, the clan leader defers to the truth, and the truth stands alone). Thus, people were prepared to follow their leaders, not because of their status, but because of their leadership qualities and ability to carry out their responsibilities.

Following the Kingdom era, each nagari in the Minangkabau world was still ruled by Tigo Tungku Sajarangan (TTS). These three partite systems consist of adat leaders (Datuk Penghulu or niniak mamak), religious leaders (alim ulama) and intellectuals or scholars (cadiak pandai). During this period, these traditional leaders had a great deal of authority in the nagari where they were located. In many ways, the nagari were autonomous and did not interact as a single unit in relation to the dimensions of traditional leadership. For this reason, it is not uncommon even today for this approach to differ in different parts of West Sumatra because of leadership decisions about its application made in earlier times.

The traditional arrangement of the Minangkabau living environment was based on the clans located in one nagari. Clan identity remains significant to Minangkabau individuals today. Originally, there were two forms of Minangkabau adat referred to as Lareh nan duo (two streams). These two streams had different leaders and clan associations. One was led by Datuk Perpatih Nan 
Sabatang with clans referred to as Bodi-Chaniago, while the other was led by Datuk Ketemanggungan with the Koto Piliang clans (Tjahaja 1976). These two streams had different styles of leadership. The Bodi Chaniago clans tended to be more egalitarian and democratic; their law was less strict; and their adat was administered by a Datuk Penghulu with two assistants called Andiko and Panungkek (Benda-Beckmann \& Benda-Beckmann 1985).

By contrast, the Koto Piliang clans had stricter adat and a more hierarchical administrative structure. In the Koto Piliang clans, the adat leader had three kinds of assistant including religious leaders (malin), administrative staff (manti) and the nagari guards (Dubalang). These four leaders were referred to as the Ampek Jinih (four kinds). As time passed, these two sets of clans developed into many modern clans that make up Minangkabau society (Benda-Beckmann \& BendaBeckmann 1985).

Indonesia was colonized by the Dutch for more than 300 years, and eventually Dutch rule affected Minangkabau leadership. The Dutch formed an adat leadership institution that was called larashoofd (Tuangku Lareh) in order to maintain their power and control over the Minangkabau people. The leader was an extension of Dutch interests in the region. The Dutch selected the larashoofd from among community leaders (Datuak Penghulu) in each nagari who supported and collaborated with the Dutch (Sunuri 2011). The Tuangku lareh was sometimes in the difficult position of having to consider the interests of two parties; the Dutch regulations had to be obeyed but the interests of the Minangkabau people he led had to be supported. The Minangkabau people seemed to be split at this time and were difficult to unite. This seems to have been the political goal of the Dutch government to "divide society from within"; by employing an ideology through which the Dutch tried to break the unity of the local communities by supporting one side while discriminating against the other or "divide et impera" (Muluk \& Malik 2009, p. 87). 
During the colonial era, the tripartite system of Tungku Tigo Sajarangan (TTS) shifted slightly compared to earlier periods. Nevertheless TTS still existed. In the colonial era, the Minangkabau people were intent on freeing themselves from colonization. This led to rebellions such as the Padri war, Manggopoh war, and the Kamang war. The aspiration to be a sovereign country resulted in some people becoming leaders, either individually or chosen by the public, to achieve freedom from Dutch control. Some major figures of the time came from Minangkabau. These included statesmen Tan Malaka, H.A Salim, Mohammad Hatta, and Syahrir. Women from Minangkabau also took part in the fight to gain independence and empower people around them. These included Rangkayo Rasuna Said, a politician; Sitti Manggopoh, a leader in the Manggopoh war against the Dutch colonial government; and Rahmah el Yunusiah, founder of an Islamic boarding school for girls called Diniyah Putri Padang Panjang (Vreedede Stuers 1992).

At this time, adat leaders (niniak mamak), religious leaders (alim ulama) and intellectuals or scholars (cadiak pandai) were all present and active in the community. Most of the leaders, however, were scholars and came from the more educated segments of the community. The emergence of women during the colonial era as described above was part of this traditional three-part leadership structure. This suggests that leadership in the Minangkabau philosophy does not derive from a set social status but is based on specific qualities and the ability to carry out the responsibilities of a leader as well as to empower people around them by teaching them skills and sharing their knowledge. In other words, while some of the attributes of leadership related to personality, others could be achieved by anyone who was motivated to do so, through education and participation in the life of the community.

After Indonesia gained independence, the traditional Minangkabau world formally became one of Indonesia's provinces and was called West Sumatra. In the early period of independence, leaders from Minangkabau took part in the new 
government of Indonesia but were not satisfied with the central government under President Soekarno who set up a highly centralized administration focused on Java (Kahin 1952; Zed 2011). They wanted a more decentralized system but the president ignored their views which resulted in rebellions in Sumatra, as well as on the island of Kalimantan and Sulawesi. In West Sumatra, the rebellion turned into civil war characterized by guerrilla tactics (perang gerilya or PRRI). At that time, the nagari still existed, but the division of government power between the central level and the West Sumatran provincial government affected the local government. The leadership of the nagari still existed and consisted of adat leaders (penghulu), religious leaders (ulama) and scholars (cadiak pandai) (Naim 2004), but also military leaders who criticized the central government and led rebellion.

During the Soeharto era, the tripartite system of Tungku Tigo Sajarangan (TTS) still existed, even as uniformity was imposed across the country by the New Order government and a system of hierarchical leadership was instituted nationwide. The TTS became a kind of informal structure relating to adat in some parts of West Sumatra that operated alongside formal leaders appointed by the government, such as neighbourhood head (lurah) and district head (camat) (Naim 2004). Thus, at this time, there was a dual system of leadership with one strand appointed formally by the central government and the other informal adat leadership. Nonetheless, the informal adat leadership may have been largely symbolic without real power to affect community policies.

More recently, in the Reform Era, the phrase 'return to the nagari' has become popular in West Sumatra as a call to return to traditional administration, namely the tripartite system that existed historically in the Minangkabau community. 'Return to the nagari' has resulted in a mixed system of government administration in West Sumatra. In all nagari within West Sumatra, leaders are recruited from the groups that have traditionally made up TTS, and include members of the Nagari Board (KAN - Kerapatan Adat Nagari) and the Nagari 
Council (DPRN - Dewan Perwakilan Rakyat Nagari). Furthermore, in an effort to represent everyone in the community, nagari leadership includes women who come from the Bundo Kanduang organisation and youth organisations. The effort to facilitate a role for women through the Bundo Kanduang organisation suggests that accepted roles for women extend into the public space; that women can contribute and empower other women. This may serve to inspire women to become decision makers.

Interestingly, women had not served as adat leaders in West Sumatra, despite their central role in the leadership of the family and clan. An exception to this sometimes occurred when a clan did not have an adat leader or when that leader was still a minor. Nonetheless, women in these positions of leadership were responsible for carrying out the traditional duties within the bounds of adat. This suggests an informal division of governance, similar to the modern branches of government found in many societies. Needless to say, the domains of this traditional system were different and included the home, family and inheritance which was the responsibility of the Bundo Kanduang, as its female leadership: adat relating to the applications of law and custom and traditionally the responsibility of men in the capacity of Datuak Pangulu; and religion. Religion, which in all historical periods refers to Islam, was also the domain of men as alim ulama, perhaps because of the nature of Islam itself. It is not possible to identify the nature of religion in the Minangkabau world before Islam but it is possible that women or both men and women played leadership roles in it at that time (see, Miksic 2004) for a discussion of early religion in this region.

Within the Minangkabau leadership, adat and culture give women an opportunity to give their opinions and be involved in community activities as much as men. But in modern political life, however, women's leadership in local and national political institutions and bureaucracy is less developed. While the province of West Sumatra has a population that accepted the precepts of Minangkabau adat, it has not had a female governor, mayors or regents. Women have and do hold 
positions of leadership in various institutions, such as in the educational sector, and some districts are headed by women. Nontheless, the public space in West Sumatra, despite its Minangkabau culture, is still dominated by men.

\subsubsection{Adat, Philosophy, and Religion of the Minangkabau People}

The traditional laws and customary practices (adat) of the Minangkabau people is not rigid but is viewed as being flexible enough to withstand changes in time and conditions. This is described in the proverb: Adat tak lapuak dek hujan, tak lakang dek paneh (Adat will not be ruined by rain nor split in the sun). Even though the Minangkabau people have tried to maintain their adat, they are also flexible in relation to contemporary issues as described in another proverb: Sakali aia gadang sakali tapian barubah (After the flood, the bathing place changes). Other traditional illustrations of how adat acts as a guide for the Minangkabau people are contained in the following proverbs: Kain dipakai usang, adaik dipakai baru (If you use clothing, it wears out: if you use adat, it stays new); Hiduik dikanduang adaik, mati dikanduang tanah (When you are alive, you are surrounded by adat; when you are dead, you are surrounded by earth). The flexibility of Minangkabau adat has also been viewed as being exemplified by the shorthand expression patah tumbuah hilang baganti (what is broken regrows) (Nasroen 1971), which is a shortened form of another proverb. This is taken to mean that adat can be continually renewed to reflect current circumstances and will not be significantly changed by this process, just as plants regrow according to their nature if they are damaged, even though the new growth may be adapted to their surroundings at the time.

The Minangkabau philosophy is based on nature which has affected the attitudes and the way of life and given a context to adat and religious beliefs (Nasroen 1971; Navis 1984). Many proverbs, such as those above, are based on nature; this includes a basic tenet of Minangkabau philosophy, Alam takambang jadi guru (Let nature be your teacher). The prominence of nature and nature images in traditional expressions of this kind is an indication of the nature of the 
Minangkabau world throughout history and the embodiment of the idea that members of the society had to adapt themselves to the characteristics of the land which served as the model for their philosophy (see, Fanany \& Fanany 2003 for a complete discussion of this).

The cultural traditions of Minangkabau society are reflected in their philosophy and adat. However the Minangkabau people are known for their Islamic faith. Religion, which in this context is only Islam, plays an important role in their everyday life. The arrival of Islam raised the possibility of conflict between religious teachings and adat, which already existed before Islam came to the region (Abdullah 1985). Nonetheless, the introduction of Islamic teachings succeeded in changing the values of the original Minangkabau people, especially in relation to social institutions like gambling, and instituted the Qur'an and Hadith as guides to appropriate behaviour. This can be seen in the saying: adat basandi syarak, syarak basandi kitabullah (Customary law is based on syarak, and syarak is based on the holy Qur'an). Now, Islamic teachings and adat are interrelated. Islamic teachings are seen as complementing adat Nasroen (1971). Adat and Islam strongly influence the behaviour of individuals in modern Minangkabau society. This can be seen in the way the Minangkabau define the nagari, which is the basic administrative structure of traditional governance. A nagari constituted according to adat must have four components; a council hall (balai adat), a mosque (musajik), a road (labuah), and a public bathing place (tapian, pamandian) (Abdullah 1985; Thomas \& Benda-Bekmann 1985).

\subsection{Values of the Matrilineal System}

The values of the Minangkabau people can be seen as having three aspects that are relevant to this study. The first of these is the value of egalitarianism. Men and women are seen as having the same rights and an equal position. The second is the value of nature as a teacher. The Minangkabau see themselves as having built a society based on the lessons available in nature. The third is the Islamic 
teachings that form an overlay on traditional values and are seen as the foundation of a tradition of progress and development.

Based on the egalitarian idea in Minangkabau society, everybody is seen and is understood to have rights in different contexts and is entitled to play a role based on his or her abilities and strengths. Even though they have different abilities and aptitudes, these differences are not seen as making people different in worth (Navis 1984), as can be seen from the proverb below:

Nan buto paambuih lasuang, nan pakak palapeh badia, nan lumpuah pauni rumah, nan kuaik pambao baban, nan binguang disuruah-suruah, nan cadiak lawan barundiang

The blind blow away the husks, the deaf fire the rifles, the crippled watch the house, the strong carry the loads, the stupid are told what to do, the clever serve as advisors.

The proverb above suggests that Minangkabau should respect each other, and that this has become part of the Minangkabau value system. Every person, whether they are weak or strong, are equally valued by their society regardless of their form of contribution or their different function

This egalitarianism originally came from nature. Navis (1984) suggests that egalitarianism can also be seen in the trees that are found in the traditional Minangkabau lands. Trees of a given type have the same function and produce the same fruit. However the fruit may vary with respect to quality and quantity. This phenomenon is also observable among people as individuals. They may have different capabilities, but everyone has the potential to gain competence and ability in theory through the desired attributes of hard work, desire to learn, generosity, piety and honesty (Navis 1984). These personal attributes reflect the ideal Minangkabau should strive to achieve. The following proverb conveys this idea: 
Nak mulia batabua urai, nak tuah tagak di nan manang, nak cadiak sungguah baguru, nan kayo kuaik mancari.

If you want to be honoured, be generous; if you want to be famous, side with the winner; if you want to be learned, study hard; if you want to be rich, strive.

These values, egalitarianism and nature as a teacher have affected the attitudes of the Minangkabau. In theory, these values are apparent in everyday life and are part of the culture.

Even though some Minangkabau scholars such as Navis (1984), Naim (1980) and Saanin (1980) comment on the egaliterianism of Minangkabau society, their understanding of the term is different from the Western concept. To many Minangkabau, egalitarianism, as discussed above, is characterized by individuals not being classified by social status but instead by social function. Saanin (1980, 141) suggests that Minangkabau society is a typical 'balance and conflict' society, which can be seen when communal property, which is inherited in the maternal line, is used to enhance their bargaining position by women seeking economic assets to secure their position. For Minangkabau men, property can be obtained through their own efforts (earnings) and based on Islamic law. In the contemporary Minangkabau society, communal property is often a source of conflict within extended families, and egalitarianism in the Western model cannot explain the way such issues are resolved.The western concept of egalitarianism is a philosophical principle that emphasizes equality and equal treatment regardless of gender, religion, economic status and political beliefs and holds that all people are fundamentally equal. Egalitarianism is often seen as a means to reduce economic inequalities or, politically, to ensure equal treatment and rights for diverse groups.In the Minangkabau system, however, egalitarianism extends only to personal social status, and does not include equality in terms of resources, welfare and social justice. 
Another element that affects the way Minangkabau people think and behave is the teachings that accompanied the introduction of Islam. Islam, in this region is seen as providing the basis for social progress and development (see Azra 2014). In the modern context, this progress is seen as relating to an urbanized life style, education, technology and organisational development. This issue has been discussed in several contexts (see, for example, Azra 2014; Fanany, Fanany \& Tasady 2014; McCulloch \& Timmer 2007).

\subsection{The Recent Situation}

While the traditional systems of administration and culture remain significant in West Sumatra and are based, as discussed above, on traditional Minangkabau values, the province is part of the modern nation of Indonesia and has been affected in various ways by the implementation of modern structures and laws since independence. An understanding of these issues is particularly relevant to this study because the electoral process is part of the modern structure of Indonesia, even in the context of local and regional parliaments that form the lowest level of the modern legislative structure.

\subsubsection{West Sumatra as an Indonesian Province}

West Sumatra Province has been a part of Indonesia since the country gained independence in 1945. The current provincial structure consists of 12 regencies and seven municipalities that are constituted as local government administrations under regional autonomy (Biro Pemerintahan 2013). To some extent, these modern divisions correspond to traditional administrative areas but were imposed on top of the nagari by the New Order government as part of its efforts to standardize administration across the country (Benda-Beckmann \& BendaBeckmann 2009).

It is interesting to note that one of regencies in West Sumatra, Mentawai, is not Minangkabau in terms of culture. Mentawai is an island off the coast of West Sumatra. Mentawai did not develop a matrilineal system like the other parts of 
West Sumatra and the people who live there are culturally different from the Minangkabau. The indigenous people of Mentawai are proto Malays who practise an animist religion. In the $20^{\text {th }}$ century, Christian missionaries came to this area, followed by the introduction of Catholicism in 1955 and Islam in 1952 (Abidin 1997; Cribb 2000).

Although Mentawai became part of the Padang Pariaman Regency during the New Order, the people there and their communities are significantly different from the rest of West Sumatra. Under regional autonomy, Mentawai became a regional government comparable to the other 11 in the province. This study does not address the political experience of women in Mentawai because they come from a culture that is not matrilineal and are subject to social and cultural forces that are different from female candidates of Minangkabau background.

\subsubsection{Population of West Sumatra}

In 2012 the population of West Sumatra was about 4.96 million consisting of 2.46 million males and 2.50 million females (Sumatra Barat in Figures 2013). As occurs in virtually every location, there is a slight population imbalance favouring women. This is also the case in the five municipalities and regencies where this research took place. These areas were the regencies of 50 Kota and Tanah Data and the municipalities of Padang Panjang, Padang and Payakumbuh). As is the case elsewhere in Indonesia (Bessell 2010), there tend to be more female voters than male voters, although a majority of candidates are male.

\subsubsection{The Dynamics and Transition of Minangkabau Culture}

For modern Minangkabau, a majority of whom now live in nuclear families, rather than in the traditional extended family context, the modern era has brought significant changes to the ways in which traditional institutions are understood and used. One reason for this has been the need to participate in modern institutions which include education, the work environment, and the political process. The form of these, and other areas of public administration, are comparable to those found in other parts of Indonesia and do not reflect the 
specific traditional culture, adat, and customary institutions of the region. For this reason, younger people especially, their experience is becoming more like that of people the same age in other parts of Indonesia, even though certain aspects of the traditional environment remain significant, especially in the family context.

To some degree, this kind of transition has affected the way Minangkabau people perceive their original matrilineal culture. Some Minangkabau writers and thinkers, such as Hamka, Naim and Amir, feel that their traditional culture has been deteriorating for a long time and attribute this to the fact that many Minangkabau people have chosen to participate in Indonesian culture but live outside West Sumatra where they marry and raise children. People in this position may seldom return to the place of birth and may have an Indonesian, rather than Minangkabau, lifestyle (Amir 2007; Hamka 1963; Naim 1987).

Even for Minangkabau people who live in West Sumatra, the influence of globalization and the central government have been felt for some time. The transition of cultural life of the Minangkabau has changed greatly over time and in specific ways during different historical periods. However, recently, in response to what has sometimes been perceived as extremely negative change (see, for example, Attubani 2012), there has been an interest in passing local laws and regulations with Minangkabau values as their base. Similar initiatives have occurred in other parts of Indonesia, such that this would be part of a larger trend that can be seen as a response to social change across the country (see, for example, Bush 2008).

\subsection{Summary}

This chapter described the context for this study in terms of culture and values of the Minangkabau people and also discussed the impacts of social change on these traditional institutions. As part of modern Indonesia, West Sumatra conforms to the institutional structure that is in place across the country and has experienced 
the same changes in government and administration. In the context of this study, this is important because the modern environment does not wholly correspond to the traditional structures in this region including with respect to the leadership position of women and their role in public life. The impact of these forces will be discussed below in chapters 5 and 6 where the findings of this study are presented and discussed. Before that, the methodology used in this research is discussed in Chapter 4. 


\section{Chapter 4}

\section{Research Methodology and Design}

This chapter describes the way this study was carried out. The purpose of this study, as was outlined above, is to determine whether the nature and values of the matrilineal system have an impact on women's political participation in local parliaments. A case study approach was used to explicate the nature of political participation by women politicians in West Sumatra and to determine the opinions of the public in this matrilineal society about women in politics. This chapter outlines the methodology for the study, the analytical approach and other issues related to the collection of data in this study.

\subsection{Research Approach}

This study takes a qualitative approach which can be defined as the collection of data through written text, spoken words and observable behaviours and the subsequent description and analysis of those data (Patton 1990; Taylor 2005; Taylor \& Bogdan 1984). In qualitative research, there are typical data collection methods that include interviews, conversations, observations, taking pictures, recordings, videos, field notes (Bloomberg \& Marie 2008; Denzin \& Lincoln 2003). These activities may be combined with data from other sources that may include a range of documents and other secondary sources.

Qualitative research has key differences from quantitative approaches; according to Creswell (2013), qualitative researchers need to establish the data by involving themselves directly in the 'natural' setting of the phenomenon of interest, meeting with participants in the field and collecting data through field notes made in dayto-day situations. The advantage of qualitative research is that it allows for the elucidation of a range of factors that cannot necessarily be counted or quantified. These factors relate to the experiential dimension of the phenomenon of interest and are typically more nuanced than quantitative data (see Ragin \& Amoroso 2011). 
Creswell (2013) identifies five main approaches for qualitative research, namely narrative research, phenomenology, grounded theory, ethnography and case study. A case study approach was used for this study. The aim of this was to allow for the presentation and analysis of the experiences of female politicians and the opinions of members of the public in West Sumatra about female leaders. This case study describes an example of a society in transition and incorporates a mix of political modern life in Indonesia and the traditional matrilineal culture of West Sumatra.

\subsection{Rationale for Using a Case Study}

A case study involves empirical observation of existing phenomena in real contexts where there are no apparent boundaries between the phenomenon and its environment (Remenyi 2012; Yin 2012). Schramm (cited in Yin 2003, p. 12) further defines the case study as a research method focusing on specific issues that have a set of questions - why, how, and what - intended to try to illuminate a specific social phenomenon. In the case of the present study, this is women in politics in West Sumatra.

This research is intended to address these three dimensions as they relate to various aspects of female political participation in West Sumatra. First, West Sumatra was chosen as the site for study because the Minangkabau people who make up almost all of the population have a unique matrilineal social structure that places women at the centre of decision making processes and traditional institutions. This was discussed in Chapter 3. Second, to answer the question as to how the Minangkabau matrilineal system affects women's political participation and the way in which this occurs, it was necessary to show how the values and nature of the matrilineal society affect female politicians in West Sumatra. Finally, this research answers the question, 'with what result?' This study examined whether or not the social context and culture of matrilineal society affects women's candidacy and length of term in the parliament. 
Case study research can be one of three types: an explanatory case study, a descriptive case study or an exploratory case study (Yin 2003). This study is an exploratory case study; it is intended to elucidate how the real context and the actual nature of matrilineal society influences and defines the experience of women in politics and women's political participation in this specific social context.

Yin (2003) suggests that the strength of the case study method is that data can be found, not only from observation in the field, but also through the use of multiple data sources and methodologies to explore and investigate the issue. In line with this opinion, Swanborn (2010) proposes that a case study may use several sources of data including documents, informant responses and notes made during observation. In the case of this study, documentary data were used to establish the nature of the modern political context, to identify female politicians and the districts they represent, and to characterize the nature of women's political participation in Indonesia and West Sumatra. Because the impact of culture and social norms on personal behaviour is largely a matter of perception, this type of data formed only a minor part of the material for this study. The majority of data were collected through an in-depth interview process. Case studies have been used to study various kinds of political and election contexts and have been reported in the literature. Examples include Childs, Webb and Marthaler (2010); (Cockcroft et al. 2010); (Bush 2011); (Murray 2010); (Balachandran \& Sekar 2013). As is the case in the present study, the aim of this approach is to investigate the factors that affect the phenomenon of interest in one particular contextual setting.

Yin (2003) discusses the importance of research design in successfully conducting a case study. He outlines five components of case study research. They are: the research question; the proposition; the unit of analysis; the logic linking the data to the proposition; and the criteria for interpreting the findings (Yin 2003, p. 21). In this study, the research focus concerned: (1) female 
politicians who are in the local parliament, their efforts to win a seat and their experiences during candidacy and in office; (2) how people (voters and community leaders) in West Sumatra view women's political participation in a matrilineal society.

These two research directions formed the basis for an investigation which rests on the proposition that the values and nature of matrilineal society in West Sumatra have affected women politicians in this area in a way that supports them in the political arena. Based taon this, the data collected was categorized by key themes such as involvement in politics, campaign strategies, barriers in politics, support from parties and families, and societal views toward female politicians.

\subsection{Selection of Respondents}

The unit of analysis in this research was the individual. This means that the primary focus of data collection was individual persons and how these individuals are affected by their setting (Patton 1990). In this research, the setting was the matrilineal system of West Sumatra. The researcher conducted semi-structured interviews with three different categories of people: 1) five women who served as legislators in the local parliament; 2) key respondents consisting of five community leaders, four male and one female; and 3) five members of the public who included three women voters and two male voters from areas where women have been elected to local government. Additional information from voters was obtained from 17 members of the public through the use of a questionnaire.

To identify female politicians, women who had served as legislators, information was obtained from the Electoral Commission of West Sumatra on the number of female legislators in the 19 local parliaments in the province. The areas in which they lived and which they represented were considered, and potential respondents were chosen by random selection from among eligible individuals based on the selected criteria. Once potential respondents were identified, these female legislators were contacted individually by phone to ask if they were 
willing to be interviewed. Each one was given a few days to consider her participation in the study and then was contacted again by the researcher. The researcher then went to see those who agreed to take part so they could read and sign the consent forms and other documentation relating to the research.

The women who participated in this study included those with incumbent status who were elected for the first-time during the periods 2004-2009 and 20092014. The reason for focusing on women in parliament in these two time periods was because these electoral periods occurred during the Reform Era since the establishment of regional autonomy at the local government level in the Indonesian system. The total number of individuals who fit the criteria of this study is shown in Table 1 below.

Table 1: Number of Female Representatives \& Incumbents in the Periods 20042009 and 2009-2014 in West Sumatra

\begin{tabular}{|c|c|c|c|c|}
\hline \multirow[t]{2}{*}{ Period } & \multicolumn{2}{|c|}{ MPs in Provincial level } & \multicolumn{2}{|c|}{$\begin{array}{l}\text { MPs in Regional level } \\
\text { (7 municipalities \&12 } \\
\text { Regencies) }\end{array}$} \\
\hline & $\begin{array}{l}\text { Men \& } \\
\text { Women }\end{array}$ & Women & $\begin{array}{l}\text { Men\& } \\
\text { Women }\end{array}$ & Women \\
\hline 2004-2009 & 55 & $5(9 \%)$ & 551 & $39(7 \%)$ \\
\hline 2009-2014 & 55 & $7(12 \%)$ & 555 & $44(8 \%)$ \\
\hline $\begin{array}{l}\text { Incumbent } \\
\text { during two } \\
\text { periods }\end{array}$ & - & - & 116 & $16(7 \%)$ \\
\hline $\begin{array}{l}\text { Total } \\
\text { women } \\
\text { MPs }\end{array}$ & & 12 & & 67 \\
\hline
\end{tabular}

Source: Election Commission of West Sumatra (KPU Sumbar) tabulation by author.

Data from the Electoral Commission at the provincial level shows that 5 (9\%) of 55 members of parliament (MPs) for the period 2004-2009 were women as were 7 (12\%) of 55 MPs for the period 2009-2014. There were 39 (7\%) women among 551 MPs in regional parliaments in the 19 municipalities and regencies within the province of West Sumatra for the period 2004-2009, and 44 (8\%) women among 555 MPs in the 19 regional parliaments in West Sumatra for the period 2009-2014. For these two 
periods in the 19 regional parliaments, 116 MPs (both men and women) were incumbents and $16(7 \%)$ of these incumbents were women. Thus, the total number of women legislators that were available to be interviewed from local parliaments at the municipality and regency levels was 67 with an additional 12 at the provincial level. Based on availability and desire to participate, the respondents for this study consisted of three members of local parliaments who had been MPs for two terms or more, one who was elected in in the 2004-2009 period and lost her seat in 2009-2014, and one who was elected for the first time in 2004-2009. These respondents were expected to provide a variety of insights in the current and past political process and to reflect on the unique aspects of their experience as it related to the matrilineal context of which they were a part.

In addition, key respondents were taken to be people who are knowledgeable about and can identify issues of interest to this research following the definition provided by Patton (1990). To this end, five community leaders were interviewed. They were the head of a nagari (wali nagari), a religious leader (alim ulama), an intellectual (Dean of the Faculty of Social and Political Sciences at a public university in West Sumatra), a cultural figure in West Sumatra (budayawan), and a member of the traditional aristocracy. These leaders were viewed as representing the traditional elites in the matrilineal society of the region. They were knowledgeable about the society and were expected to have influential opinions and insights that might both reflect and influence the views of the public. Interviews with these community leaders were important to get a better understanding of the social context and values of the matrilineal system in which female politicians live and work and to gain insight into general societal attitudes relating to women in politics in this society.

Efforts were made to identify leaders who came from the areas where women had been elected in the 2004 and 2009 electoral periods. Where 
female MPs were already taking part in the study, the researcher inquired about who was considered a leader in that location. This word of mouth was effective in identifying key respondents and fitted with prevailing social norms where it is considered appropriate to gain introductions to people of importance by canvassing friends and relatives to find someone who can provide an introduction. Once identified, these individuals were contacted and informed about the nature of the research and arrangements were made to show them the consent forms and documentation so they could decide whether they wanted to participate.

The third category of respondents included constituents and voters who had voted for female candidates in elections. Five voters were interviewed. They were a male colleague of one female MP, a retired female civil servant, a housewife, a single parent with three children, and a businessman who had lived outside West Sumatra and then returned to the province to live. These individuals were identified in the same way the community leaders were and the same process was used to obtain their agreement to participate in the study. In addition to interviews with these five voters, an additional 20 voters were asked to complete a questionnaire which asked about issues similar to those explored in the interviews. The aim of using questionnaires in this way was to supplement information collected through interviews and to gain a better understanding of the range of opinion about female legislators.

\subsection{Data Collection}

In this study, the data were divided into primary and secondary types and were collected from various sources. The primary data were collected by using indepth, semi-structured interviews with open-ended questions to women politicians, community leaders and voters as members of the community. In addition, to obtain further information about voting patterns and public opinion during the two elections of interest, questionnaires were used to canvas the 
opinions of an additional set of voters as a means of cross-checking information obtained by other means. Secondary data were derived from government documents and local parliaments, online resources, institutions and organisations, such as the Indonesian Electoral Commission (KPU-Komisi Pemilihan Umum), and the cultural organisation called the Consultative Assembly for Minangkabau Adat (LKAAM-Lembaga Kerapatan Adat Alam Minangkabau).

The primary data were collected over three months from August 2012 to October 2012. Within these three months, a series of interviews was conducted for 15 respondents with the duration of each interview being 1-2 hours. Several of the respondents were interviewed twice as the data collected in the first interview was inadequate. During these three months, the questionnaires were distributed to 20 members of the voting public. Despite efforts to obtain completed questionnaires from all 20 respondents, only 17 voters, 11 women and 6 men, completed the full questionnaire. All the in-depth interviews were recorded and observations were also made to supplement the information they produced.

As there were demands on the respondents' time, it was necessary for a number of interviews to be conducted in public places (offices, mosques on religious occasions) or at the respondents' homes. This allowed for observations to be made of the individual's interactions with others in the community and for her relationship with other people to be evaluated. As a result, the researcher had an opportunity to see the respondent's interaction within her family and, in one case, with a constituent who came to see her. In interviewing two female politicians in their offices, the researcher was able to see some of their professional activities and also listen to informal conversation in a professional context. This allowed the researcher to observe interaction among colleagues in local parliament and note their behaviour. In observing community leaders; the researcher witnessed interaction and conversation between community leaders and their extended family in the village where the researcher was present at a gathering to celebrate the end of the fasting month (Idul Fitri). The researcher attended and participated 
in a meeting relating to a cultural event at an art gallery (Taman Budaya Padang) and was taking notes while two community leaders participated in the meeting.

These observations were a useful supplement to the interviews themselves because the researcher was able to gain additional insight into the way other people perceived the respondent which allowed for triangulation of the more subjective aspects of the interviews. The importance of this type of supplementary data is discussed by Creswell (2013).

\subsection{Analysis of Data}

Yin (2003) discusses five steps for the analysis of data collected through interviews. They are: (1) collection of verbal data; (2) reading of the data; (3) breaking data into themes; (4) organisation and expression of the data from a disciplinary perspective and linking between the proposition and field notes; and (5) synthesis and summary of the data. Bloomberg and Marie (2008) stress the need to organize and reduce raw data through coding and categorization that will support the articulation of findings based on analysis.

The data for this study were analysed using the five steps recommended by Yin (2003). All interviews were transcribed, and the transcriptions were divided into three parts corresponding to the data from the five female politicians, the five community leaders and five voters. Each transcription was read and reread and notes were made of important points associated with research questions so that the data could be coded.

Relevant pieces of data were then categorized and organized into themes based on respondents' perspectives and interpretation of the researcher. Four main themes emerged: significant factors in winning elections; the disadvantages of the matrilineal and Indonesian political system for women; public views about female politicians; and linkages between modern political life and matrilineal society. 
These themes were used to identify the experiences of female politicians, to understand the viewpoints of community leaders and voters about female politicians and to characterize the ways in which matrilineality has affected women in politics in West Sumatra.

\subsection{Reliability, Validity and Reflexivity}

Reliability and validity are a concern in all empirical social research. Four tests are often used to assess reliability (see Kidder \& Judd 1986) and can be applied at various stages of research. Specifically, processes for ensuring construct validity, internal validity, external validity, and reliability should all be incorporated into research design and analysis of data to produce research that is trustworthy, credible, and confirmable with highly dependable data (see, for example, Golafshani 2003 and many others for a discussion of these principles).

Yin (2003) outlines a set of methods for establishing reliability and validity in case study research. This study made use of these methods which were incorporated into the research design as follows. Construct validity relates to the choice of measures used to study the concepts of interest in a specific research project. The aim is to avoid subjective interpretation of data and is relevant to the data collection and analysis stages.

In this research, several measures were used to ensure construct validity. These included the use of multiple data sources, as discussed above, and also the use of key informants to check findings. External validity relates to the domains in which the results of research might be generalizable. This can be established by the use of existing theory which is applied in the context of the case of interest. A number of theories about women's participation in politics that are reported in the literature were used to develop the research questions for this study and were used as the standard against which the findings were considered.

Reliability relates to the degree to which the findings of a study are free from bias. Methods for avoiding these problems involve establishing a research 
protocol that guides how the research was carried out and that allows the same steps to be repeated. A research protocol was essential in this study because of the need to interview a set of respondents about the same issues. This also ensured that each respondent was given the opportunity to discuss the same issues and was asked about them in the same way. In addition, the data collected from respondents in this way was entered into a database that was used to catalogue the statements of the respondents and was kept separate from the analysis of its content. In this way, the material of study (respondents' statements) has been made available for further study or for re-analysis if desired as a means of assessing its reliability.

Internal validity was not a concern in this research because it was an exploratory case study intended to elucidate the nature of the phenomenon of interest. Internal validity is a concern when causal relationships are being established and it is important to avoid incorrect assumptions or spurious connections (see Cook \& Campbell 1979; Silverman 2006). Reflexivity is an additional concern in research of the type reported here. Reflexivity relates to the position of the researcher with respect to the study context and respondents and the development of selfawareness about the research process. The aim of developing this kind of awareness is so that the researcher is conscious of any biases or assumptions that he or she may be applying to the data collected and its analysis (Begoray \& Bannister 2010). In other words, reflexivity is a required attitude on the part of the researcher to compensate for his or her position in relation to the research context.

In the present study, the researcher is a woman and a member of the Minangkabau society of West Sumatra. While this provided certain benefits, such as the ability to use the local language as well as Indonesian in conducting interviews and an insider's understanding of social issues and norms, it also meant that the researcher may have had certain fixed ideas about the culture and its values as well as the ways in which women politicians are perceived by the public. For this 
reason, this study was developed with awareness of four principles intended to overcome any biases that may have come about through a lack of reflexivity, namely: theory construction, methodological disclosure, development of a narrative voice and presentation of a polyphonic text (Chiseri-Strater 1996 ).

A theory about the nature of women's participation in politics in West Sumatra is embodied in the research questions for this study. This theory comes from the literature reviewed in Chapter 2 above and is based on observations in various parts of the world in different political systems. The methodology for this study is explained in the current chapter and was designed to operationalize as many aspects of the research process as possible with the researcher applying a process of continuous self-reflection in all aspects of the data collection and analysis. The presence of the researcher's narrative voice is observable in the positioning of text and findings and efforts have been made to indicate what constitutes analysis and what constitutes data. Finally, efforts have been made to allow the respondents to speak for themselves by presenting a large number of quotations from their interviews in their original language (Minang and Indonesian). These are translated for a reader's convenience but are presented as they occurred so that others who speak these languages can evaluate them in their original form.

\subsection{Translations}

The data for this study consisted largely of interviews that were transcribed for study in the languages in which they took place. Respondents in this study used both Minang and Indonesian at various times with certain individuals using one or the other to a greater extent. All excerpts from the interviews that are presented in this thesis were translated into English, and the translation is presented along with the original and an indication of the language of the excerpt. All translations here were checked by Associate Professor Ismet Fanany of Deakin University who is a native speaker of Minang and Indonesian. However, any errors contained in these texts are the responsibility of the researcher who made the initial translations and who was present at the original interviews. 


\subsection{Ethical Considerations}

Ethics approval for this study was obtained from the Human Research Ethics Committee of Deakin University. The study was classified as high risk because investigation into the political context in Indonesia was deemed to be potentially risky for the respondents. No other ethical issues were experienced during the conduct of this research.

In all phases of this study, the identity of participants was protected and all identifying statements were removed from the final presentation of data. Participants were advised that they could withdraw from the study at any time and were not required to answer every question. Written consent was obtained from all participants who were also given time to reconsider their participation between the time of consent and their interview. Interview transcripts and other data were stored securely and are not accessible except to the researcher and her supervisors at Deakin University.

\subsection{Limitations of the Study}

As noted in Chapter 1, the limitations of this study related to the small number of individuals interviewed. While this is appropriate for a case study, it should be noted that the pool of appropriate participants in West Sumatra was limited because of the requirement that women who took part as the main participants have a specific political experience and status. While a larger number of community leaders and voters were available, it was necessary to include only individuals who were located in the regions represented by the women who were identified as fitting the criteria of this study. For this reason, the findings of this study may not be representative of Indonesia as a whole but do provide insight into the political context in one province of the nation and allow for an understanding of the experience of female politicians in that setting. 


\subsection{Summary}

This chapter provides a description of how this research was carried out. A qualitative approach was determined to be most fitting to work with the available data and to explore. An exploratory case study approach was chosen to describe the phenomenon of political participation by women in modern West Sumatra which included not only their experiences, but also the opinions of community leaders and voters within the context of the traditional matrilineal society as discussed in Chapter 3 of this thesis. A number of measures were taken to ensure the reliability and validity of findings and to address potential issues of bias relating to the position of the researcher relative to the respondents and contextual setting. These are described above, along with the ethical and translation issues relevant to this study and its limitations. 


\section{Chapter 5}

\section{Female Politicians: Pathways, Efforts and Experiences}

This chapter presents the findings of this study that came from interviews with female politicians in West Sumatra regarding their experiences, efforts, and pathways into politics. This chapter contains 11 subsections. The first of these describes the women who took part in the study, while the remaining subsections relate to common themes in the experiences of the respondents. They are: involvement in politics; inspiration to enter politics; opinions of family members; their role in the extended family and support gained from this; people and organisations that supported their candidacy; skill as a politician; obstacles faced as female politicians; societal opinions; reaction of political colleagues; campaign strategies; and strategies used by incumbents to maintain their position.

\subsection{The Female Politicians}

Five female politicians were interviewed for this study. Three were incumbents who had recently been re-elected, one had served a term of office but lost her seat in the most recent election, and the fifth had just been elected to her first term in office. These five women come from various parties. Since the start of the Reform Era, there have been more than 30 political parties in Indonesia while during New Order Era under President Soeharto, there were only three: the Functional Group Party (Golongan Karya - Golkar), the United Development Party (PPP - Partai Persatuan Pembangunan) and the Indonesian Democratic Party (PDI - Partai Demokrasi Indonesia). Below is description of each of the candidates and her affiliation.

Respondent 1 represented the Golkar Party in one of the local parliaments. This party has existed since Soeharto was elected president for the first time and was the ruling party during the New Order. The party is a social and organisational group run by the Joint Secretariat of the Functional Group (Sekretariat Bersama Golongan Karya). The organisation was founded by a group of army officers in 
1964 in order to limit the growth of the Indonesian Communist Party (PKI) at that time. After this, the organisation served to place President Soeharto in office in the 1971 election. Since that time, Golkar was supported by the Indonesian military, which allowed him to maintain his power. The electoral dominance of Golkar can be seen in the results of subsequent elections; the party won $62 \%$ in the 1977 election, $64 \%$ in $1982,73 \%$ in $1987,68 \%$ in 1992 , and $74 \%$ in 1997 (Encyclopedia of the nations 2014). The Soeharto government collapsed in 1998 and what is often referred to as the Reform Era began. Even though in the 1999 election, Golkar took $20.9 \%$ of the vote, the Golkar party successfully weathered this period and emerged with a new paradigm and leadership to become one of the major parties of the Reform Era (Tomsa 2008). Respondent 1 commented that she joined this party because her extended family had been involved with Golkar since the 1980s. Her brother-in-law was a successful businessman at the national level who had many business ventures and he also was an elite member of this party. She had assisted him administratively, including with his party activities, since 1985. As a result, respondent 1 had been familiar with and was affiliated with this party for more than 20 years.

Respondent 2 represents the National Mandate Party (PAN - Partai Amanat Nasional) in one of the local parliaments in West Sumatra. The party was founded in 1998 by Amien Rais, who holds a PhD in Political Science from a US university. It is a moderate Islamic party and was originally the political wing of Muhammadyah, the second largest religious organisation in Indonesia. Nonetheless, in its early years, the party changed its ideology. As suggested by the newspaper, Republika Online, it was no longer an Islamist party but a nationalist party open to everyone such that it included many pluralist and interreligious figures (Putra \& Festiani 2013). In the Reform Era, many people supported the party's position but its proportion of the vote decreased nationally in three legislative elections. In the 1999 legislative election, PAN won $7.1 \%$ of votes, in 2004 the figure fell to 6.4\%, and in 2009 it gained only 6\%. In West Sumatra, which has many members of Muhammadyah, PAN is one of the five 
strongest parties that have their greatest support outside of Java. Respondent 2 asserted that she joined this party in 1998 coincidentally when she returned to her hometown. Her father is a Muhammadyah activist and Islamic theologian in Padang Panjang, one of municipalities of West Sumatra. This respondent was already familiar with the Muhammadyah organisation before she became involved in PAN and was elected as its MP.

Respondent 3 comes from the Crescent and Star Party (PBB-Partai Bulan Bintang). Similar to PAN, the party emerged during the Reform Era in 1998. This party's platform is based on Islam, and it is considered the successor of the Council of Muslim Organisations (Masyumi - Masyarakat Muslim Indonesia). Masyumi was a party that existed during the Soekarno administration and won the second largest share of the vote, with 20.9\%, in the 1955 election (Encyclopedia of the nations 2014). However the party was banned during the New Order, under the Soeharto administration. Respondent 3 emphasized that her involvement with this party was a way to get closer and easier access to the public and to work for social justice and welfare of the people since she is neither a civil servant nor a member of the judiciary and hence cannot contribute in another way.

Respondent 4 represents the United Development Party (PPP - Partai Persatuan Pembangunan). This Party was established for the 1971 election as a merger of four Islamic Parties: Nahdatul Ulama (NU), the Muslim Party of Indonesia (Parmusi), the Islamic Association Party of Indonesia (PSII) and the Islamic Educational Movement (Perti). The merger of these four parties was at the instruction of President Soeharto who felt there were too many parties in the 1971 election and reduced them to two or three based on their platform. This respondent said that, during New Order, she was already a member of this party. She affirmed that, as a member of a marginal party, she had had some 'bad' experiences and faced pressure from Golkar members and even the Golkar elite in her area. Despite this intimidation, she has remained loyal to her party. 
Respondent 5 also represents PAN, but in a different local parliament from Respondent 2. She was familiar with and became a supporter of PAN when her father became an elite party member in her area in 1999. She was already active in her village community as treasurer of the Social Empowerment Institution (LPM - Lembaga Pemberdayaan Masyarakat) and the Family Welfare Education Group. She became an active member on the committee of the PAN party in 2003. Full support from her extended family led her to become a candidate in the 2004 election, and she served as an MP for two periods representing the PAN party. More detail, background information and the personal status of the five respondents is contained in table 2 below.

Table 2: Background of Female Politicians Interviewed for the Study

\begin{tabular}{|c|c|c|c|c|}
\hline $\begin{array}{l}\mathrm{N} \\
\mathrm{O}\end{array}$ & $\begin{array}{l}\text { Female } \\
\text { Politicians }\end{array}$ & Background & $\begin{array}{l}\text { Period as } \\
\text { MPs }\end{array}$ & $\begin{array}{l}\text { Experience } \\
\text { and Pathway } \\
\text { into Politics }\end{array}$ \\
\hline 1 & $\begin{array}{l}\text { DOB } \\
\text { 4/7/1955 } \\
\text {-Married } \\
\text {-Two } \\
\text { children } \\
\text {-One } \\
\text { grandchild } \\
\text { Businesswo } \\
\text { man }\end{array}$ & $\begin{array}{l}\text {-Bachelor of } \\
\text { Economics, } \\
1980 . \\
\text {-Comes from } \\
\text { large family } \\
\text { with a national } \\
\text { business. } \\
\text {-During } \\
\text { candidacy, had } \\
\text { full support } \\
\text { from extended } \\
\text { family. First } \\
\text { time as MP }\end{array}$ & $\begin{array}{l}2009-2014 \\
\text { Served as } \\
\text { interim } \\
\text { replace- } \\
\text { ment } \\
\text { (PAW) } \\
\text { since 2010 }\end{array}$ & $\begin{array}{l}\text {-Limited } \\
\text { experience in } \\
\text { politics } \\
\text {-Some } \\
\text { administrative } \\
\text { experience in } \\
\text { Golkar Party; } \\
\text { assisting her } \\
\text { brother }\end{array}$ \\
\hline 2 & $\begin{array}{l}\text { DOB } \\
\text { 10/11/1966 } \\
\text {-Married } \\
\text {-Two } \\
\text { children } \\
\text {-Employed } \\
\text { by private } \\
\text { company }\end{array}$ & $\begin{array}{l}\text {-Bachelor in } \\
\text { Law, } 1990 . \\
\text {-No interest in } \\
\text { politics before } \\
\text { Reform Era. }\end{array}$ & $\begin{array}{l}2002-2004 \\
2004-2009 \\
2009-2014\end{array}$ & $\begin{array}{l}\text {-First time to } \\
\text { be elected - } \\
\text { Had limited } \\
\text { experience in } \\
\text { politics but } \\
\text { active in } \\
\text { several } \\
\text { religious } \\
\text { organisations }\end{array}$ \\
\hline 3 & $\begin{array}{l}\text { DOB } \\
\text { 9/9/1966 } \\
\text {-Unmarried }\end{array}$ & $\begin{array}{l}\text {-Bachelor's } \\
\text { degree in Arts }\end{array}$ & $\begin{array}{l}2004-2009 \\
2009-2014\end{array}$ & $\begin{array}{l}\text {-Some } \\
\text { experience in } \\
\text { youth affairs, }\end{array}$ \\
\hline
\end{tabular}




\begin{tabular}{|c|c|c|c|c|}
\hline & $\begin{array}{l}\text {-Teacher at a } \\
\text { college in } \\
\text { Padang }\end{array}$ & $\begin{array}{l}\text { and Social } \\
\text { Sciences, } 1991 . \\
\text {-Post graduate } \\
\text { degree in } \\
\text { Management, } \\
2006 . \\
\text {-Political views } \\
\text { changed during } \\
\text { Reform Era and } \\
\text { became } \\
\text { involved in } \\
\text { politics }\end{array}$ & $\begin{array}{l}\text { (lost } \\
\text { election } \\
\text { for second } \\
\text { term) }\end{array}$ & $\begin{array}{l}\text { student and } \\
\text { religious } \\
\text { organisations, }\end{array}$ \\
\hline 4 & $\begin{array}{l}\text { DOB } \\
\text { 13/3/1968 } \\
\text {-Married } \\
\text {-One child } \\
\text { (adopted) } \\
\text { - } \\
\text { Entrepreneur }\end{array}$ & $\begin{array}{l}\text {-Graduated from } \\
\text { commercial high } \\
\text { school (SMEA) } \\
1991 . \\
\text {-No formal } \\
\text { background in } \\
\text { politics }\end{array}$ & $\begin{array}{l}2004-2009 \\
2009-2014\end{array}$ & $\begin{array}{l}\text {-Involved in } \\
\text { PPP in 1996; } \\
\text { ran in } 1997 \\
\text { and } 1999 \text { but } \\
\text { lost in these } \\
\text { two elections }\end{array}$ \\
\hline 5 & $\begin{array}{l}\text { DOB } \\
\text { 13/6/1972 } \\
\text {-Married } \\
\text {-Two } \\
\text { children } \\
\text {-High school } \\
\text { teacher }\end{array}$ & $\begin{array}{l}\text {-Bachelor } \\
\text { Degree in } 1996 . \\
\text {-Father is } \\
\text { businessman } \\
\text { and public } \\
\text { figure in her } \\
\text { region }\end{array}$ & $\begin{array}{l}2004-2009 \\
2009-2014\end{array}$ & $\begin{array}{l}\text {-Involved in } \\
\text { politics since } \\
\text { Reform Era }\end{array}$ \\
\hline
\end{tabular}

Source: Interviews conducted by the author.

As indicated in Table 2, the five female politicians who took part in this study have various backgrounds, ages, and experience as MPs, and pathways into politics. In terms of education, three (respondents 1,2, and 5) have 13 to 15 years of formal education; one (respondent 4) has 12 years, and one (respondent 3) more than 16 years. Their educational background is in various areas including economics, law and social sciences. Most were under 40 when they became involved in formal politics and won their first election with the exception being informant number 1. She first ran in 2009 when she was 54 years old. Four of these female politicians are married; one (respondent 3) is not. Three (respondents 2, 4, and 5) still have children living at home while one (respondent 1) has adult children who do not require her care. 
As noted above, the occupations of these women vary as well and include both business and educational fields. Most had some experience in social and political organisations. The Reform Era in Indonesia allowed for the establishment of numerous political parties that served the interests of diverse segments of society and allowed members of the public to choose a party that best suited their interests. This new political environment also seems to have created new opportunities for female politicians, in part because additional parties mean that more candidates can participate in elections. Four of the women who participated in this study entered politics in the Reform Era. Only one was active before that.

It can be seen from table 2 that the marital status, family background, experience and pathways into politics of these respondents is quite varied. These characteristics were explored more deeply through interviews how they became involved in politics, who inspired them to enter politics, the opinions of their family about women in politics, their role in the extended family, the people and/or organisations that supported their candidacy, what forms this support took (financial, material or non-material), obstacles faced by female politicians, societal views about female politicians, the reaction of colleagues towards them as female politicians, their campaign strategies (particularly if these differed for incumbents and first time candidates), and their perceptions of whether it is more difficult for women to succeed in politics than men. Taken together, these responses illustrate the experience of women in politics in the Minangkabau matrilineal society from the point of view of the female politicians themselves.

\subsection{Involvement in Politics}

One of the five female politicians interviewed said that she never imagined she would enter politics, much less hold office for more than two terms of office. Previously, she worked at a weekly children's magazine in Indonesia's capital, Jakarta. During the Asian economic crisis in 1998, she lost her job. At the same time, her mother became ill in her hometown, so she returned to take care of her. When her mother recovered, she accepted an offer to join PAN (Partai Amanat 
Nasional - National Mandate Party) and became active in its administration in her area, which is quite remote in 1998. Her work was satisfactory to other members and party committees. Eventually, she became head of the ballot committee in her area. In 1999, she was given a chance to run for office as a PAN candidate but refused because she thought her political background was insufficient and she was not interested in running. Speaking in Minang, the local language of West Sumatra, she described this experience as follows:

". . Iyo awak ndak berminat, karano nio balik ke Jakarta. Kawankawan di PAN ko terus jo mempersiapkan [persyaratan untuk jadi caleg-red]. Akhirnyo kawan-kawan ko yang mengurus berkas, inyo yang melengkapi semua persyaratan. Akhirnya setelah selesai Pemilu, kursi di timur ko dapek sakarek."

“. . . Actually I was not interested because I wanted to go back to Jakarta. But my colleagues in PAN set up the requirements for candidature. In the end, it was them who did all the paperwork and fulfilled all the requirements for me. Finally, after the election, it turned out we won half a seat here in our region." (Interview with Respondent 2, 21/9/2012).

This woman began her career as a party administrator and tried to do that job as well as she could. Because other party members were impressed and they chose her to be their candidate. Thus, her candidacy was via the initiative of her colleagues even though the woman in question was not actively interested in holding office. In response to this, she did return from Jakarta and took her seat in parliament for eighteen months between 1999 and 2004. Under current electoral law, it is possible for two candidates from the same party to share a seat in parliament, with each serving half the electoral term. This system of vote counting takes into account differential shares of the popular vote obtained by candidates from a single party in one region. For this reason, this respondent served half terms in office. She ran again in the two subsequent elections and retained her seat for 2004-2009 and 2009-2014.

By contrast, respondent 1 explained that her parents are social activists in her village. Her extended family founded an early childhood education institution, 
providing a place for people in the village to hold monthly meetings for women in nearby neighbourhoods, meetings of Family Welfare Education groups (PKK - Pendidikan kesejahteraan Keluarga), fitness activities, and Qur'anic study groups. These local activities prompted members of the public to propose this woman run for office to represent them in the 2009 election. Nonetheless, she was in the second position on the list of candidates and failed to win a seat in parliament. Her region won only one seat which went to the first listed candidate. This person resigned after a year in office, however, because he won the election for Regent of the 50 Kota Regency, in the eastern part of West Sumatra. In the event of a resignation of this kind, the second candidate on the list replaces the first one to represent the party in parliament. This meant that this respondent's status was an interim replacement (PAW - Pengganti Antar Waktu), a position she has held since 2010, rather than as outright winner in the last election.

Respondent 5 discussed the positive impact her father's status had on her political career, particularly in gaining access to the voters and winning their support. This woman became involved in political activities in the Reform Era and eventually joined the PAN party. Since that time, she has been an active member and on the committees of this party. Her activities resulted in her being given an opportunity to run as a representative of PAN.

Respondents 3 and 4 stated that their involvement in politics began because of their background of active involvement in various organisations and political parties since New Order Era. The Reform Era gave them greater opportunities to run for office.

\subsection{Inspiration to Enter Politics}

These women's inspiration to enter politics came from two main sources. The first of these was self-motivation and educational background. The second was family history, including a father who is active in the community and organisations and who encouraged political participation. The father of 
respondent 2, for example, is active in the Muhammadiyah Organisation, and the father of respondent 5 is affiliated with the PAN Party, while the parents of respondent 1 are affiliated with and active in Golkar. These women's fathers inspired them to be persistent and disciplined and to learn from their experience. One respondent stated in Minang:

"Apa (panggilan untuk bapak) ndak pernah maaja urang manjo. Nyo pantang maaja urang manjo. Kami pun dibaitukan . . . Kok awak padusi ko aa ..."Pa taragak bali radio tape yang ba ampli . .. " a paga lun ba cat lai. . ko paga cat dulu ... beko lah salasai baru bali. .."

"My father never spoiled us. He didn't want any spoiled children. So he never treated us like that even though we were his daughters ... I remember when I wanted to buy a tape player with an amplifier. He told me to paint our fences first, because the fences need to be painted. When that was done, he bought me the tape player. .." (Interview with respondent 5, 4/9/2012).

Another respondent, speaking in Minang, also explained how she was treated by her father:

“. . . Yo disiplin . . . Kalau iyo tu iyo . . . kalau indak tu indak. . . Aaa dari segi tanggung jawab sangat tegas. Gaek (Ayah) maagiah pitih balanjo limoratuih . . kama pai pitih tu . . balanjo apo se."

"Well, it was discipline. If it was yes, it was yes . . . If no, then no. In terms of responsibility, he was very strict. If he gave me even 500 rupiah, he wanted to know where the money went, how I spent it." (Interview with respondent 2, 21/9/2013).

By contrast, Respondent 4 stated that her motivation to become involved in politics came from within herself. She had been interested in politics since childhood and followed political campaigning. She described this in Indonesian:

“. . . Dulu di tahun 1995 itu Buk, saya kan masih belum berkeluarga ... kebetulan di kampung saya Sungayang itu ada komisaris PPP Kecamatan . . Dia menemui saya dan mengatakan bagaimana kalau saya masuk ke partai. Jadi saya karena memang sejak kecil, 
SMP kita kan waktu itu lihat orang kampanye memang ikut juga kampanye."

“. . . In 1995 when I was still single, there happened to be an official of the District PPP Party in my village of Sungayang. This person came to me and asked if I wanted to join the party. I did because I had been interested in the campaigning since I was in junior high school and even took part ..." (Interview with respondent 4, 25/9/2012).

She was asked by the organizers of the United Development Party (PPP - Partai Persatuan Pembangunan) to join the party in 1995 and has dedicated her time and energy to their goals since then. She ran as a PPP candidate in the 1997 and 1999 elections. Despite losing those elections, she persevered and was finally elected in of 2004-2009 and re-elected in 2009-2014.

\subsection{Opinions of Family Members}

When asked about the opinions of their family members, all of the women interviewed reported receiving a positive response from husband and children, brothers, sisters, parents and parents-in-law. One female politician asserted that her parents were surprised and found it hard to believe when they heard she was running for office. She asked a male colleague to visit them and explain that she really was a favoured candidate and had a good chance of winning a seat in parliament. Speaking in Minang, she explained:

“. . . Tak percaya ... tak percaya bahaso kito ka sato Pemilu. Tapi kok marami-rami kan biaso se. Iyo ka caleg ko . . . iyo ka caleg ko ... Baitu mereka batanyo-tanyo . . Iyooo jawab kito . . terpaksa kawan partai yang laki-laki kito bao ka rumah, minta tolong mangecekkan ke keluarga bahaso awak iyo caleg pulo . . akhirnyo keluarga baru percaya..."

". . . They did not believe, just did not believe, I would be in the election. As a supporter, sure, that would be usual. But as a candidate? They asked me many times . . . are you sure? Yes, I told them. Finally, I brought a male colleague to the house and asked him to tell them that I really was a candidate. Only then they finally believed it ..." (Interview with respondent 3, Sunday, 9/9/2012). 
Another respondent had the full support of a brother who was a businessman in Jakarta. He supported her financially because none of their siblings works for the government or is involved in the public realm. The family felt that having one of them serve in political office would raise the standing of the family. This respondent explained in Minang:

“. . . Haa . . . mengangkat . . istilahnya dalam keluarga kami ndak ado yang PNS do. Ndak ado do . . Y Ya pengusaha kami ... dan kakak yang tuo pun karajo di swasta lo kan... Adek yang ketek di swasta. . . Jadi untuk mengangkat namo keluarga tu, kakak ko ingin awak mencalonkan diri. Calon dari seluruh partai. . . alhamdulillah awak yang tertinggi."

“. . . It would raise our profile. In our family, no one was a civil servant. We are all in business and even the oldest works for a private company. The youngest, too. So to honour the family name, my oldest sibling wanted me to nominate myself and, of all the candidates, I won." (Interview with respondent 5, 4/9/2013).

\subsection{Support and Role in the Extended Family}

When asked about their position in the extended family and specifically about their role as a matrilineal leader in the Minangkabau cultural context (as Bundo Kanduang), the women interviewed for this study gave a range of answers. Of the five politicians, only one (respondent 4) is a family leader in the matrilineal context; the rest have large families with five, seven, or eight siblings. Generally, it will be the oldest daughter who is entitled to play a role in family leadership. The campaign of one respondent, for example, was supported financially by her older sister who was able to lend her funds. This money came not from the communal property of the extended family but from the sister's husband who is an entrepreneur. In the case of these female politicians, some enjoy strong support from the sister who is the head of the family. Others received continuing moral support during their campaign and political career. One respondent, speaking in Indonesian, said: 
“Justru beliau dorong kita, Ayoo Tis coba aja . . katanya . . kapan lagi katanya . . . kan udah pensiun . . .kapan lagi mending di kampung Tis sekalian jagain rumah ... kita kan bisa buat macammacam di sini katanya. Iyalah..."

"It was she [the older sister] who encouraged me...Come on Tis, she said. When else are you going to do this? she said. You retired from your job [in Jakarta], so when else are you going to do something in the village. You can mind the house at the same time. We can do all kinds of things here, she said ..." (Interview with Respondent 1, 31/8/2012).

This respondent added that, during her first year in parliament, she was surprised at the behaviour and lack of discipline of other MPs. She told her sister about this unsatisfactory situation and said she wanted to resign. Her sister responded by encouraging her, calming her down, and comforting her. The respondent explained what happened in Indonesian as follows:

“. . . Lho kenapa ...? Hee . . . . itu pengalaman hidup itu. Tambahan lagi kita bisa belajar, jadi kita bisa bedain mana yang baik mana yang tidak. Udah bertahan aja." dia bilang gitu . . . O iyalah tadinya memang awalnya ndak kuat."

“... Why .. .? Huh ... it's all experience. We can learn from it, so we can tell the difference between good and bad. Just hang on," she said. Oh yes, in the beginning, I couldn't stand it." (Interview with Respondent 1,31/8/2012).

One respondent, who is the head of her family, had a different experience. In her case, she is the one responsible for addressing any issues in the extended family. As an MP, this status as a leader extends beyond the confines of the extended family. She explained in Indonesian:

“. . Kalau dulu rumah kita itu kan rumah gadang buk . . tahun 1991 rumah itu dibongkar karena sudah tua dan jadi rumah batu permanen seperti sekarang ini. Masih menempati rumah itu saya. Jadi kalau saya di keluarga itu betul-betul tumpuan keluarga . . Ya jadi Bundo Kanduang."

“. . . We used to live in a traditional house. In 1991, though, it was demolished because it was old and we replaced it with the brick house. I'm the one who still lives there. In my family, I'm the one 
they all rely on, a true Bundo Kanduang . . ." (Interview with Respondent 4, 25/9/2012).

She later returned to this theme:

“.. . Sekarang buk bukan tempat mengadu keluarga saja, tapi juga dari sukunya. Kalau yang membuat saya senang di organisasi dan anggota DPRD ini, itulah buk . . . saudara banyak keluarga bertambah..."

". . . Now, it's not just the family who comes to me for help, it's the whole clan. What makes me happy is, in the organisation and the parliament, it's like I have more siblings and more family . . ." (Interview with Respondent 4, 25/9/2012).

For this woman, at least, her role as leader of her family, combined with her political office, gave her a double responsibility which she accepted and which pleased her.

The support these five women politicians received during their candidacy from their extended family is noteworthy. Three (respondents 1,3, and 5) had full financial support, while two (respondents 2 and 4) enjoyed the moral support of relatives. Additionally, two of them, respondents 1 and 5, benefitted directly from their family's social and economic status. Their fathers are prominent figures with greater access to voters. The remaining three do not have these kinds of connections and entered politics based on their own qualifications and initiative.

Three of the politicians (respondents 1,2, and 5) who took part in this study stated that after they got married, they lived as a nuclear family in a different house from their parents or the family's traditional house (rumah gadang). One (respondent 4) still lives in the communal house in her village and is also a leader in her extended family (Bundo Kanduang). Another respondent who is unmarried lives with her parents. Female politicians who live with their nuclear family are generally not leaders in their extended family. They do not live on the communal property of their extended family. Even though they live separately, they are still in contact and communicate with their extended family. Even the decision to enter 
politics is normally based on the considerations of their clan and input from their extended family. Speaking in Indonesian, one respondent said:

“. . . Keluarga besar mendukung . . . awalnya di kampung kemarin kan kebetulan bertiga kita yang mungkin dicalonkan. Ya Itis yang menawarin, sekarang gini deh, siapa yang mau maju ... daripada buang-buang duit. Ya yang lain itu masih muda-muda . . . masih punya ambisi kuat ke yang lain ... dan yang dua itu tak bisa pulang ke kampung. . . ya udah akhirnya dijalani aja."

“. . . The extended family fully supported us . . in the beginning, there were three of us in the village who could have run . . . It was me who suggested we do it like this: one of us should just go ahead, instead of wasting money. The other two were still young; they had other ambitions and couldn't go back to the village ... so in the end, I just did it." (Interview with Respondent 1, 31/8/2012).

This respondent stated that before she became a candidate, there was a family gathering to choose from three possible candidates in her extended family. The decision that someone from this extended family would try to enter politics had already been made and was seen as benefitting the family in the long run.

Even though they live separately from them, these female politicians still maintain a good relationship with their extended family. On occasions like weddings, Idul Fitri (the celebration at the end of the Muslim fasting month of Ramadan), and Idul Adha (Feast of Sacrifice), they celebrate with family at the family's traditional house or their parents' house. One respondent, speaking in Indonesian, mentioned:

“. . . Pokoknya sekeluarga itu .. gimana ya . . . adik kakak, kayak gimana kita waktu masih kecil-kecil, seperti itu juga sekarang... suka ngumpul . . . suka ini . . yah maksudnya masih utuh lah kita."

"Our family, it's like brothers and sisters, like when we were little, we're still like that now. We often get together, we like it . . . we still stick together." (Interview with Respondent 1, 31/8/2012).

When asked about whether it is difficult to get together with her family because they now live apart, this respondent replied: 
“. . Sering (maksudnya sering bertemu) . . . kita kalau lebaran kadang-kadang di Jakarta ngumpul. Kadang-kadang di sini, di tempat Uni (di rumah gadang, dan Uni maksudnya Bundo Kanduang)...."

"... We do meet often ... at the end of the fasting month, we sometimes celebrate in Jakarta, sometimes here at my older sister's house - at the traditional house where my sister is the head of the family." (Interview Respondent 1, 31/8/2012).

This female politician has a close relationship with her extended family. Even though they live separately, they are close enough to celebrate important events together, such as Idul Fitri. Another respondent does not attend family events personally. She is sometimes represented by the female leader of her family because she lives in another area. Speaking in Minang, she explained:

“. . Iyo, Pi sajak pindah ka Tiaka (nama satu kelurahan di Kota Payakumbuh) yo ndak pernah sato pai baralek kampuang lai . . . karena lah jauh tingga dari keluarga. Tapi kok ado nan tapek bana baru kito pulang ka Payobasung. Kok ado kematian ... a a yoo tibo . . . ndak diwakili."

“. . . Well, since we moved to Tiaka (near Payakumbuh), I haven't been going to the weddings of relatives who are not really close to me because I don't live near the family, but if it's really necessary, then we will go to Payobasung for something. If someone dies, then I go myself, I don't have someone represent me." (Interview with Respondent 5, 4/9/2012).

She continued that even if the person who died was not a close relative but came from her clan, she would attend the funeral. Speaking in Minang, she said:

“. . Ndak na dunsanak tapek bana, sapasukuan tu awak langsung turun. Ba a namonyo tu ... pai tu dicaliak-caliak bana lai ... dibagibagi ... kalau urusan Koto Baru Payobasung tu kakak sepupu. Kalau bagian sabalah siko yo awak. . ba bagi-bagi lai."

"If they're from our clan, then I go; what do you call it, I pay my respects, but I have to balance it. If something happens in Koto Baru, Payobasung, then my cousin does it. I do my part in this area, we divide the responsibility." (Interview with Respondent 5, 4/9/2012). 


\subsection{People and Organisations that Support Their Candidacy}

Differences in their perceptions of support from organisations and people outside their family were visible among the five women interviewed. The level of support they received differed the first time they ran as compared to later elections when they were the incumbent. Four of the respondents (respondents 2, 3, 4, and 5) noted that, when they ran for the first time, support came from their extended family, people in their community who voted for them, and organisations they were affiliated with such as Social Empowerment Institution (LPM - Lembaga Pemberdayaan Masyarakat), Family Welfare Education groups (PKK); partyaffiliated organisations; the youth organisation, Karang Taruna; Quranic recitation groups (Kelompok Pengajian Yasin); and the Muslim womens'organisation, (Badan Kontak Majelis Taklim-BKMT). Support in the form of funds as well as verbal affirmations in public came first from their relatives and later from members of the public.

In her first campaign, respondent 1 was supported by several organisations where she was a member. These included the female civil servants' organisation, Dharma Wanita; the Family Welfare Education Group, PKK; and the parents and school community of the early childhood education institution where she worked.

Respondent 2 stated that she was fully supported by the members and committee of her party, even though she was not interested in running at that time. By contrast, respondent 4, said that she was self-motivated to run and, as an entrepreneur herself, did not accept money from her extended family. Instead, she relied on her skills to build a good relationship with members of the public and important figures like community leaders, the heads of youth organisations, and her business colleagues. She also worked hard for her party, demonstrated her loyalty, and learned from her experience when she failed to be elected in the 1997 and 1999 elections. 
In their second campaign, most respondents utilized their assets as MPs. In addition to a budget from the parliament, they were able to save their income as a member of parliament and use those funds to support their campaign. One respondent explained in Minang:

“. . Jadi itu tergantung awak mengelola hubungan baik. Ndak ado ... Ndak pernah kami anggarkan khusus itu . . . ndak . . Tapi istilahnyo bilo ada perjalanan ke luar daerah, misal ke Jakarta, maka kita sisihkan, misalnya ke Solo ... maka kita beli bahan dasar baju batik... ber ball ball . . buat puluhan konstituen."

"So it depends on how you develop good relationships. There is no ... I never budget for this specifically. But if I have to travel outside the region, to Jakarta for example, I set aside some of the budget allocation. One time, I went to Solo and bought bolts of batik material for my constituents ... hundreds and hundreds of meters . .." (Interview with Respondent 5, 4/9/2012).

This statement reflects one respondent's view on the importance of maintaining a good relationship with constituents. Other respondents expressed similar views, reflecting their awareness that they rely on the public for their position. They have to be alert, to watch and read the situation, and address the needs of their constituents.

\subsection{Skill as a Politician}

Some respondents stressed that skill is important, but female politicians still have to prove that they are as qualified as male politicians. One respondent stated that female politicians have to prepare mentally and physically for the role. This is because challenges may come not only from inside parliament but also from the public. One respondent explained in Indonesian:

“. . . Hmm sebetulnya begini lo . . kalau kita mau terjun ke politik ... kita harus siap mental . . terutama sekali buat yang mudamuda ... Mapan dulu deh baru masuk gitu lho, haa jadi kita masuk di sini nggak macam-macam gitu lho."

“. . . It's like this, if you want to enter politics, you have to be prepared mentally. Especially for younger people . . . It's better to establish yourself first and then go into politics, so if you do, you 
can avoid the bad behaviour ..." (Interview with Respondent 1, $31 / 8 / 2012$ ).

She asserted that, in addition to skill, access to a large amount of money is important for politicians. This, she suggested, will allow them to avoid corruption because they have enough money to live on and to take care of their constituents as well as for their campaign expenses.

Another respondent said that political skill cannot be gained instantly, cannot be obtained through formal schooling, but is instead a process. She explained in Indonesian:

"Ya. . . Jadi memang membina hubungan dengan masyarakat itu tak seperti kita dapatkan sewaktu kuliah. Itu tak mudah buk. . . Memang mempunyai ilmu tersendiri, memimpin itu ada ilmunya dan ada seninya. . . Tak semua orang bisa dekat dengan masyarakat. Ya karena berdekatan dengan masyarakat itu berasal dari hati yang dalam ... tak bisa dibuat-buat ... soalnya akan kaku kalau dibuat-buat."

"So yes ... Creating a good relationship with the community is not like they taught us at university. It isn't easy and there is a trick to it and an art. Not everyone can do it. To get close to the public, it has to come from your heart, you can't fake it. It will be awkward if you try." (Interview with Respondent 4, 25/9/2012).

Another respondent mentioned that she feels there is stigma felt by female politicians based on the idea that politics is not appropriate for women and it is necessary to prove to people that women can be as effective as men in this job. This respondent stated in a mix of Minang and Indonesian:

“. . Iyooo sebenarnya belajar sendiri itu yang penting. . . Otodidak. . . baa caro urang buek laporan. Ooo taka iko . . awak se improvisasinyo ... soalnyo ndak ado aturan baku di dewan pun di partai . . . jadi kadang awak lempar pun ka partai ndak ada respon ... jadi pas pandangan umum awak buek se surang."

"... Well it's important to teach yourself, to be an autodidact . . . How do you make a report . . . Oh, it's like this, I just improvise. The thing is, there are no real rules in parliament or from the party. 
If you send it to the party, you get no response, so if the general observation is correct, you just do it yourself." (Interview with Respondent 2, 21/9/2012).

This respondent felt strongly that she had to figure out for herself how to do the work required without formal instruction. This highlights the need for training and political awareness. It should be noted that male politicians no doubt are in the same position but this lack of training nonetheless highlights a major difficulty for newly elected politicians in general.

\subsection{Obstacles Faced as Female Politicians}

In responding to questions about whether female politicians experience more obstacles than men, most of the women interviewed here felt that they had less time than their male colleagues. Furthermore, one respondent recognized that as a woman, she cannot move as freely as male politicians. She asserted that she is uncomfortable when she has to attend functions at night even though she has no real evidence that people in the community view this negatively. This respondent explained in Minang:

“. . Yaa perempuan ko ndak bebas do untuk bergerak. Kalau apakapak ko kama jo bisa bebas. Kalau padusi ko ndak bisa do .. . Bacaliak lo dulu malam ko kama. . .kalau pai rapek mungkin lai bisa lah... pi kalau pai duduak duduak ajo mode ota di lapau itu ndak mungkin do... banyak kendala cewek . . memang banyak."

"... Well, women cannot move freely. For men, if anything comes up, they can be free to just go. Women can't do that. They have to look and see where they are supposed to go at night. If it's a meeting, maybe that's fine. But if you're just going to sit around in a coffee shop and talk to people, that is not possible. Women face a lot of impediments, there really are a lot." (Interview with Respondent 5, 4/9/2012).

Additionally, there is a general idea that women are responsible for doing a range of domestic tasks, supporting family members, and taking care of children. The women interviewed here did not feel they could attend hearings and meetings that 
often last until midnight. They also feel guilty if they cannot give enough time to their family. As one respondent said in Minang:

"Adolah... kendala waktu pastinya ... kalau lah sanjo tu ari masih di kantor... lah tu gelisah ... Nan kaduo kalau jadwal makan siang ko ha ... takana anak dan keluarg."

"Yes ... Time constraints are an obstacle. If it's getting dark and I am still at the office, I do become anxious. Second, if I have to attend a lunch, I always think of my children and family." (Interview with Respondent 2, 21/9/2012).

Another obstacle is the fact that there are few women in parliament and they rarely hold strategic positions. As a result, their views may be submerged by other opinions. One respondent explained in a mix of Minang and Indonesian:

“...Aaa kalau perjuangan sebagai anggota dewan sebetulnya sama sulitnya dialami anggota dewan perempuan dan laki-laki. . . Tapi ya . . . itu stigma . . . stigma yang diberikan masyarakat. Imej itu membuat perempuan tak berdaya . . Ahaa. . baru ka mancogok la ditokok. . . Ya satu sisi mereka menghalangi kita, tapi sisi lain mereka mengandalkan kita untuk kerja dan menjadi peredam bila bertengkar dengan eksekutif."

“... If it's a question of position, actually men and women members have the same problems. But yes, there is stigma. Stigma comes from the public. That image makes women powerless. Ah, as soon as you're about to speak up, you get pushed down. On the one hand, they hold us back, but on the other, they rely on us to do the work and mediate if there are problems with the executive branch." (Interview with Respondent 3, 9/9/2012).

\subsection{Societal Opinion}

The respondents in this study had experienced a range of societal opinions about women in politics. These ranged from people underestimating them because they were women, welcoming them in this role, to viewing their participation as something usual and appropriate that might lead to an increasing number of women becoming politicians. 
One respondent has the impression that most people in her circumstances see politics as inappropriate for women. She stated in Minang:

“. . . Masih agak miring juo baru . . . karena mereka menilai padusi ko memang ndak cocok di politik ... dari segi waktu dan dari segi hiduik kareh . . . kareh dan lagi banyak . . . apo namonyo tu . . .a nan di politik ko a a istilahnyo. . . a iyo . . . trik-trik dan lobi-lobi yang tak sehat."

“. . . People still consider it odd, because they think it is inappropriate for women to be in politics ... in terms of time and in terms of the hard life. It's hard and there are a lot of, what do you call it, tricks and unfair deals among politicians ..." (Interview with respondent 2, 21/9/2012).

Three respondents (respondents 1, 4 and 5) felt that people around them respected their status as MPs. One respondent explained in Indonesian:

"Ya mereka (masyarakat) kayaknya biasa-biasa aja ya . . Mereka siap shi menerima, malah saya untuk periode berikutnya saya dah bilang ke anak muda itu. Ayoooo masuk, masuk jadi politisi . . . Ndak buk. . . takuik. . Ibu ajalah yang maju."

“. . . People seem to feel it is perfectly ordinary. They accept us. In my second term, I suggested to the youngsters that they try to become politicians, too. They said they were afraid and said I should just continue to represent them." (Interview with respondent $1,31 / 8 / 2012)$.

Another respondent noted people seem to expect there will be an increasing number of female politicians. Speaking in Indonesian, she said:

“. . Saya melihat masyarakat sangat berharap dengan banyaknya anggota dewan perempuan, tetapi tidak semua perempuan ketika itu yang mau turun .. . Iya mereka diharapkan tapi tak mau turun."

"... I think people have high hopes for more women in parliament, but a lot of the women members, but not all of them at the time, were willing to meet with the public. People hoped they would, but they didn't." (Interview with Respondent 3, 9/9/2012). 
By contrast, some people in the community tended to criticize female politicians or react cynically. One respondent explained that people mocked her. She said in Minang:

"Adoo. . . tapi Alhamdulillah lai bisa mengatasi . . Aa yang ndak digosipkan urang. . .malah ado dapek terror bagai . . Istrinyo sms, meneror di sms tapi yo awak ndak mesti tertekan. Ado yang memaksa minta bantuan, ndak diagiah mancimeeh. Tapi itu kan ndak harus . . kalau memang tak ado a nan ka diagiah."

"It was bad but I managed. They would talk about me. Someone even tried to terrorize me. Somebody's wife sent me text messages, tried to terrorize me by text message, but I could stand it . . . Someone else tried to force me to help him, and when I didn't, he taunted me. That was unnecessary. If I don't have it, how could I give it to him?" (Interview with respondent 5, 4/9/2012).

\subsection{Reaction of Political Colleagues}

The reactions of their political colleagues towards female politicians fall into two categories. The first of these relates to underestimating female politicians (reported by respondents 2 and 3), and the second is respect for them and treating them as equals (described by respondents 1, 4, and 5). All five respondents understood, however, that their colleagues came from different backgrounds that were likely to affect their views and behaviours. They also realized they had to persist and show their colleagues that women have the same capabilities as male politicians. They had to be firm and maintain their opinions while participating in decision making in the political context. One respondent said in Minang:

“Iyoo . . . awak ditinggakan ... seolah-olah ... 'eehh padusi ko ee . . . 'mereka ndak menganggap awak lai. Mereka menganggap kalau lah dapek ketuanyo . . . nyo beko ikuik se tu nyo."

"They leave us out. It's as if they think, 'oh, these women.' They don't pay attention to us. They think we'll just find a leader and go along with that person's decisions ... ." (Interview with Respondent 2, 21/9/2012)

She continued in a mix of Indonesian and Minang: 
"Yo masih . . . masih dianggap sebelah mat. Dianggap remeh juo. Cemeeh kawan-kawan tu ado sajo ... a kalau lah kareh awak stek . . . komentarnyo: 'Aaa lo maunyo tu?' Tapi awak tetap jalan taruih.”

“. . . Yes, they still don't pay attention to us, they don't think we're important ... They mock us when we speak up. They say, 'what does she want?' But I just keep on doing what I do ...” (Interview with Respondent 2, 21/9/2012).

Another respondent agreed that female politicians had to be persistent. She explained in a mix of Indonesian and Minang:

"Kalau secara keseluruhan tergantung kita pula untuk menempatkan diri, ketika itu ada enam anggota dewan perempuan. Oo memang tergantung perjuangan awak pulo dan memang harus dikeraskan suara stek. . . ya harus keras . . . suara secara tone itu yang pertamo, kedua secara prinsip dan ketigo berani menyerang dan yang keempat harus bisa lo mangapa tinju ... Iyoo . . . sebab kito di dunia maskulin . . haa begitu stigmanya."

"Overall, it all depends on us to position ourselves. At one time, there were six female members. It was up to us and we did have to raise our voices. Yes, we had to be tough. In terms of tone, that was the first thing. The second was our principles and, third, we had to be willing to attack. And fourth, we had to show we were ready to fight. Because this is a man's world, that's the stigma ..." (Interview with Respondent 3, 9/9/2012).

Others have experienced positive reactions from their colleagues, indicating that these colleagues value them. However, the respondents who reported this also noted that they had to earn this respect. One said in Minang:

“. . . Ndak ado perbedaan. Yoooo dianggap nyo awak lai . . . Yo itu pandai awak pulo ... kalau ndak bagak yo dimakannyo awak... harus bagak."

"... There is no difference in how they see us. But it's up to us. If you can't be fierce, they'll eat you alive. You have to be fierce." (Interview with Respondent 5, 13/9/2012, $2^{\text {nd }}$ interview). 
These female politicians understood that the reactions of their colleagues were likely to be varied, depending on their background and point of view. However, even those who felt they had earned the respect of their colleagues, recognized that the most important aspect of their interaction in parliament was their own capabilities and capacity to assert themselves in the political context.

\subsection{Campaign Strategies}

These five female politicians realized that their constituents were important in winning a majority of votes. For this reason, they used various strategies to win their constituents' support. All of them, whether in their first term (respondent 1) or experienced (respondents 2, 3, 4, and 5), admitted that they felt they had to spend money on promotional items such as banners, pamphlets, calendars, brochures, T-shirts, hats and ribbons. These items were distributed to potential voters in their areas and the banners hung in strategic locations. They also said they did not make promises to their constituents during the campaign but they expended a lot of effort to find out how to hold onto their constituents even though several of them did not have much money for their campaign. One respondent described this in Minang:

“. . . Aaah ambo kadang bapikia juo nak . . . ambo ndak dapek sponsor dari manapun. Jadi biaya sorang . . Mungkin dek salamo patang ko ambo ndak ado maagiah pitih kontan ka urang-urang do ... Cuma yang ambo sampaikan ka konstituen, cuma pernyataanpernyataan seandainyo ado kegiatan-kegiatan kok bisa ambo tolong . . . tapi kecekan ka ambo ... jadi ambo ndak menjanjikan maagiah pitih do, kalau ado kegiatan kok bisa ambo tolong. ..."

“. . . I sometimes think about it, I didn't have a sponsor and had to pay for it all myself. I never gave my constituents cash. I just told them ... I said that if they have an event and want me to do something, please let me know. So I didn't promise to give them money, but I could help if they wanted me to . .." (Interview with Respondent 2, 21/9/2012). 
She continued that, during her term of office in 2003, she succeeded in convincing the government to build a public health centre (Puskesmas) in her area, even though the population of this area did not meet requirements for having a public health centre. However, she was able to convince the decision makers that people in this remote area needed their own health care facility. She said in Minang:

“Ambo malobi pak Walikota, subananyo ndak layak didirikan Puskesmas di situ karena jumlah penduduk nan saketek. Tapi dek lobi-lobi ambo jo Bapak Walikota dalam kapasitas sebagai anggota dewan ... Ambo kecekkan daerah tu terpencil, masyarakat butuh. . akhirnyo bisa diadokan Puskesmas di Koto Katiak tampek ambo ko ... Nnah itu kan mambuek sanang warga sebab mereka ndak jauah-jauah lai pai barubek..."

"I lobbied the Mayor. Actually, it was not appropriate to build a health centre in the area because so few people live there. But because of my lobbying in my capacity as a member of parliament, I said that the area is isolated, the people need it . . . Finally, and they did build a health centre in Koto Katiak, this place of mine. That made the public happy because they didn't have to go someplace else to see a doctor . .." (Interview with Respondent 2, 21/9/2012).

Similar to respondent 2 above, respondent 4 commented that she did not make promises to her constituents. She explained in Indonesian:

“. . . Untuk diketahui Buk . . saya sebelum dilantik tahun 2009, saya tak berhenti silaturahmi ke sana. Hanya waktu kampanye dulu saya mengatakan tak bisa berjanji apa-apa, tapi apa yang menjadi kebutuhan masyarakat akan saya perjuangka. Jadi saya tak berani berjanji. Kalau soal saya berjanji tidak tertepati oleh saya . . . itulah yang membuat saya tidak berani bertemu dengan bapakbapak dan ibu-ibu . .."

“. . . Just so you know, before I was sworn in in 2009, I kept in touch with my constituents. During the campaign, I told them that I couldn't promise anything but I would fight for whatever they needed. I didn't dare promise anything. If I made promises I couldn't keep, I would have been afraid to face the public . . ." (Interview with Respondent 4, 25/9/2012). 
On a different note, one of the respondents explained how she used her family's resources to win support. She explained in Indonesian:

"Misalnya konstituen minta kegiatan senam, sudah . . . se Dapil satu kita adakan senam di rumah gadang. Fasilitasnya kan ada gitu haa ... haa. . haa ... Ya kalau ada yang minta ngaji ya Yasinan . .. Ya kita kumpulin . . adakan juga di rumah gadang."

"For example, if my constituents wanted an exercise class, I set this up at our family's traditional house. We had the facilities for it. If they wanted Quranic recitations, we got them together and did it at our house ...”(Interview with Respondent 1, 31/8/2012).

This respondent utilized her family's communal property to gain the support of her constituents. She acknowledges that this was not a problem for her extended family. She also admits that most of her support came from women.

Another respondent explained a different campaign strategy. She expanded her vote to target the scholarly community since she was enrolled in a master's program at one of the private universities in West Sumatra and also often met with Islamic leaders since she was trying to target voters from Muslim Women's Organisation (BKMT - Badan Kontak Majelis Taklim). Speaking in a mix of Indonesian and Minang, she explained:

“. . . Hmm kampanye terbuka itu sekedarnya saja. Yang penting pendekatan ke masyarakat dan masyarakat pun yang didekati mesti sama persepsinya dengan kita. Kalau kita mendekati secara agamais, secara intelektual . . . sementara masyarakat itu tidak agamais, tidak memiliki kadar intelektual yang sama . . itu tak bisa ... tidak tune in nyo do."

“... For an open campaign, you just do what you can. The important thing is to approach the public. And the people you approach have to have the same views as you do. You can't use a religious approach or an intellectual approach if they aren't religious and aren't at the same intellectual level. You can't do it. You have to tune in." (Interview with Respondent 3, 9/9/2012). 


\subsection{Strategies Used by Incumbents}

Four of the respondents in this study were incumbents who had been re-elected to the same office. Their strategies for winning votes were somewhat different the second time around. These strategies are described below, beginning from respondent 2 and proceeding to respondent 5 in numerical order.

Respondent 2 decided to target older women and women in rural areas as her voters. The reason she chose this demographic was because she thought older women might be more loyal than younger voters. She explained in Minang:

"Nan ciek lai ambo pakai system perempuan sebagai pemilih . . . Ambo pilih lo nan tuo-tuo di rumah . . karano nan tuo-tuo ko lah dapek ciek nyo ndak amuah pindah lai do. Kalau pemilih pemula nan awak targetkan payah awak. Lai dicubo . . umumnyo mereka kan anak sekolah SMA, labiah condong mamiliah gurunyo. Di Padang Panjang ko ado labih duo ratuih caleg, ado guru-guru nan caleg tu, nyo tiok hari basobok jo gurunyo jo awak indak. . ."

"I targeted women as voters. I chose the older ones at home because these women, once they decided on something, they weren't going to change to something else. If you target new voters, it's hard. I tried it . . . They're high school kids, they tend to vote for their teachers. In Padang Panjang, there were more than 200 candidates, and some of them were teachers. These kids saw them every day but they didn't know me." (Interview with Respondent 2, 21/9/2012).

When asked to describe these constituents further, this respondent stated in Minang:

“. . . Yo yang lah baumua tu lah . . yang kaduo ambo maingek urang tu tiok tahun tiok tahun... 'Mak manga mak . . a ko paket tuak amak . . ka rayo yo mak'. . . Aa tu nan berkesan dek urang gaek ko. Jadi ambo buek paket lebaran tiok tahun ambo antakan ka rumah amak-amak tu a a nyo takana tu. . 'sia dek amak nan dipiliah mak...?' 'Ma nyo si Epa. . haa di muko rang rami mode tu se tu nyo.' Aaa begitu orang tuo-tuo tu. Aaa jadi kalau urang gaek tu awak agoah perhatian ... nyo konsisten. bahkan urang gaek ko nyo pengaruhi lo anaknya . . . pilih se si Epa . . . nyo taruih maagiah 
paket ka awak ma ... Yoo ado kemungkinan maningga pas Pemilu ... tapi yo itu kan resiko dan ndak mungkin lo sadonyo . . ."

“. . . With these older ones, I keep reminding them over and over again. 'Ma'am, how are you, Ma'am? This is for you, Ma'am, for the holiday [at the end of the fasting month].' That makes an impression on older voters. So I get holiday packages for them every year and take them to the houses of these older women to remind them. 'Who are you going to vote for, Ma'am?' I'd say. 'Where are you on the list?' one asked me in front of other people. That's what these old ones are like. You're safe with them. They're consistent. They can even influence their children. 'Vote for her', they'd say. 'She gives us a present every year ...' There is a chance they'll die before the election, but that's a risk you take. . ." (Interview with Respondent 2, 21/9/2012).

This respondent noted that she chose to target older women, based on her experience with the public and her interest in psychology. She stated in Minang:

“. . . Mungkin juo dek suko mambaco urang . . . pengalaman psikiater ndak jadi . . . jadi lah suko mambaco urang . . . O kalau taka iko ndak namuah do nak. . . taka iko . . bisa ma . . Yo baraja sorang se... Jadi apo lai kalau urang mudo, mereka susah dipacik. Waktu urang Pemilu tu aaa ... ambo yang habis pas rayo tu se nyo. Ambo balian batik gulung panjang tu ... beko kalau ado konstituen ko nan baralek. .. mereka minta baju seragam batik, ambo balian ... atau kebetulan kawan uda (suami) ado di Solo ... a a titip tu . . ."

“... I try to read people, but I have no psychiatric experience. I just try to read them. If they're like this, they won't want such and such. If they're like this, then they can. I taught myself this ability. With younger people, you can't get a grasp. During the election, it was right after the holiday [at the end of the fasting month], I bought a big bolt of batik material. If any of my constituents was getting married, if they asked me for batik uniform material, I gave it to them. Or if one of my husband's friends was going to Solo [in Java], I would ask him to buy it for me . . ." (Interview with Respondent 2, 21/9/2012). 
She further asserted that another target demographic is women in rural areas. She realized that these women work in the fields every day and are not interested in the issues of importance in urban areas. She explained in Minang:

“Aaaa nan kaduo padusi . . a tapi jan padusi nan mudo-mudo . . . padusi ibu-ibuklah berkeluarga petani tu. Iiyoo ibu-ibu petani tu kegiatannyo kan ka sawah, rumah, kadai. Kan itu se dunianyo tu. Jadi jaan padusi mudo nan banyak pai-pai, sekolah atau kegiatan kalua . . . Mereka tu kan banyak tahu, aaa payah awak mangabeknyo. Awak se mangabeknyo . . yo awak antakan paket tiok tahun sampai mereka bakomentar, 'baagiah jo taruih ma yo.' Jadi itu nan awak bina ka konstituen . . . maagiah mereka tiok tahun."

"The second (group of voters) is these women, but not younger women, the mothers of these farming families ... These women's life centre on the rice fields, the house, and their small shops. This is their world. I don't bother with the younger ones who are going to school or doing this and that. They have a lot of knowledge, and it's hard to get them. I just try to get (the older) ones. I take them something every year so they realize I am continuing to do this. That's how I develop the constituency, I give them things every year." (Interview with Respondent 2, 21/9/2012).

These older women and farm women were this respondent's target demographics during the 2004 election. In the next election in 2009, she maintained these constituents and added more voters by trying to raise her popular image. This respondent distributed a vest with her name written on the back to motorcycle taxi drivers. She discussed this in Minang:

“. . . Untuk tahun duo ribu sambilan ko ambo buek spanduk limo, latakkan di tampek strategis . . . sudah tu buek seratusan baju rompi. Rompi batuliskan namo awak diagiahkan ka tukang ojek. Iyoo ojek tu kan di arak-araknyo namo awak. Ndak ka miliah ndak anti, awak ndak yakin ka miliah awak ... tukang ojek kan lihai ... tapi paling ndak namo awak diarak-araknyo taruih."

“. . . In 2009, I made five banners and put them up in strategic locations. Then I got a hundred some vests with my name on them. I gave these out to the motorcycle taxi drivers. So they were wearing my name in the taxi ranks. I didn't know if they would vote for me though. These drivers have their own interests, but at least they were 
wearing my name wherever they went." (Interview with Respondent 2, 21/9/2012).

Respondent 3 was unsuccessful in gaining a seat for a second term. Comparing her strategies in her first election in 2004 and her second in 2009, she felt she had a great deal of opportunity in 2004 since she was put first on the list of candidates. Her supporters came from her extended family, people in her community, the academic community, theologians and some organisations. In the 2009 election, her party decided to put her third on the list of candidates. She did not feel that the new regulations issued by the Elections Commission affected her candidacy much. When asked about how she maintained her constituents, she acknowledged that she did make an effort to do this but was unable to avoid the inherent difficulties in the political situation. She described this in Minang:

“. . . Dihunian jo dipaliharo lai . . tapi kilau . . . kilek ko mangilaukan ... ba a lo cek awak. . tahun duo ribu ampek sempat kehilangan suaro. Jadi isu jual beli suaro. Mengambil suaro itu bukan isu. . . itu sebenarnya. Tahun duo ribu sembilan lebih parah lagi ... sado TPS tulah tagadai sado alah e tu . . istilah kami ado Tsunami Democrat. Kito ndak amuah sato . . . sebab apo ... . amanah kito tarimo, pitih kita hamburkan . . lai yakin awak ka bisa . . akhirnya apo anggota dewan kini . . korupsi banyak kini kan . . bla . . bla . . ndak bisa karajo dek mancari pitih. Kalau kito sampai diberangi dek partai. Eeh ba a kok di dewan se, Iyo . . . partai mengamanahkan kita untuk di parlemen dan melaksanakan tugas-tugas dewan.”

“. . . I do maintain my constituents. But yes ... there is an effect. What can I say? In 2004, I lost some of my support. There was talk of vote buying . . . that vote getting is not just a rumour, it actually happens. In 2009, it was even worse. All of the voting districts bought into it ... we called it a tsunami from the Democrat Party . . . I didn't want to get involved in this vote buying because I had a mandate. It would be wasting money. I was sure I could manage. Finally, the members...there's so much corruption now . . . blah, blah . . . you can't get any work done because you're looking for money. You end up getting reprimanded by the party. That's how it is, the party gives you a mandate and you have to do the work of the parliament." (Interview with Respondent 2, 21/9/2012). 
This respondent continued that, in her second term, she realized that the political situation had changed suddenly and the management of the election seemed too vague. Moreover, her party colleagues also wanted to run in 2009. As she understood this situation, she accepted her colleagues running in the same election and accepted her party's decision to put her third on the list of candidates.

As she explained in Minang:

“. . Iyo nan kaduo. . . kito apo yo ... kalau di Minang itu, Gabak di ulu tando ka ujan, Cewang dilangik tando ka paneh. . . itu kan ado perubahan undang-undang. Perubahan undang-undang itu dua kali, nyaris tiga kali, yang pertama berdasar nomor urut, yang kedua berdasar suara terbanyak, person, yang ketiga suara partai. . . itu Perpu ketika itu . . . terakhir injury time. Kito sudah di legislative ketika itu. Tentu kito menyikapi . . . kito tahu . . ya lagian kawan-kawan di partai. . . nio pulo . . ingin pulo mancubo pulo . . .kito mungkin sudah menjadi sikap diri. . .Kalau aia gadang ko ndak bisa diambek . . ka ateh musti barubah . . Kito beri laluan."

“. . . In the second election, I uh, as we say in Minang, 'Thunderheads upstream are a sign it's going to rain; cirrus clouds in the sky are a sign it's going to be hot.' There was a change in the law. It changed twice, almost three times. The first was based on the order candidates are listed, the second was based on who got the most votes, the third was the party's choice. The new law at the time ... the last was 'injury time'. I was in the legislature at the time. Of course I accepted this, I knew my colleagues in the party wanted in, too. They wanted to try, too. That's how it is. 'If the water can't be held back, something upstream has to move.' So I let them go ahead." (Interview with Respondent 3, 9/9/2012).

Respondent 3 admitted that she did not feel regret when she lost the second election. She prepared to adjust even though some of her friends, acquaintances and colleagues seem to feel they had misjudged her. As she explained in Minang:

“. . . Alhamdulilah daripado korupsi sebagai anggota dewan . . . Kok ka makan pitih ba a caro ka mamulangkan lai . . sebab waktu yang berlalu tak bisa diputar balik... jadi memang kita sudah siap. 
Tapi kita sebagai kader partai adalah kewajiban kita untuk mensukseskan partai, kita harus ikut bertarung."

“... Thank God, rather than get involved in corruption as an MP, (I was happy to have lost the election). If you take the money, how can you give anything back because you can't turn back time. So, I was prepared (to lose). But as a member of the party, it was my responsibility to make sure the party won, so I had to play the game ...” (Interview with Respondent 3, 9/92012).

Respondent 3 acknowledged that she gave as much as she could to her constituents before she stepped down as a member of parliament in 2009. She kept her promises to her constituents, visited them, and apologized for anything she might have done wrong doing since being elected. As she said in Minang:

“. . . O kita habis-habisan . . . menghabiskan amunisi. . . menunaikan janji, menunaikan amanah ke masyarakat, acara reses, acara baiak buruk turun ke masyarakat. Partamo minta maaf, nan kaduo . . ooo. . . apo nan ndak tasilau disilau, bajalan babuah batih, balenggang babuah tangan, sampai keluarga berang ... awak se ndak adoh ... urang diagiah. Iko amanah. Mano tahu urang tu dulu maminta ndak taagiah, mano tahu urang tu tacaliak tapi wak ndak taraso. Rayo ko memang diapoan ko mah . . . kok ndak bisa nol nyo anam ... gak tigo angko gai malah ... dan kata orang kita habis-habisan . . . tidak . . . kita mau menyudahi pengabdian dengan manis. Sebab menyudahi pengabdian dengan manis mandaki tu yo sasak angok. . . Tapi kalau manurun ... Kalau ndak hati-hati,lutuik guyah . . . kapalo dulu pacah . . . Jadi kito hiduik jo urang gaek. . Urang gaek itu masak. . jaan sekali-kali aia dibaliakkan ke hulu . . ikut air mengalir kalau dak bisa ka siko harus kalua di situ."

“. . . I used up everything . . . all my ammunition . . . I kept my promises, fulfilled my mandate to the public, during recesses, good or bad, I went back to the community. First, I apologized. Second, the ones I hadn't had contact with, I went to see. 'When you walk, your legs are your capital; when you swing your arms, your hands are your capital.' My family was angry with me. We don't have and you're giving to other people, they said. This was my mandate. There might have been people who asked for things but didn't get them. Maybe I had seen these people but hadn't noticed. I gave them something on Hari Raya (the holiday at the end of the fasting 
month). If I can't manage millions, I go with thousands. And people said I was using everything up. But it wasn't that. I wanted to end my term nicely. And to do that, 'when you go up (hill), you breathe hard.' But when you go downhill, if you're not careful, your knees can't hold you and you crack your head'. I lived with my parents; they did the cooking and things. You can't make water run upstream. It keeps flowing. If it can't go here it comes out there." (Interview with Respondent 3, 9/9/2012).

Respondent 4 also described her campaign experiences and strategies. She ran four times, in 1997, 1999, 2004, and 2009. When asked how she felt when she failed to gain a seat in parliament in 1997 and 1999 and how her family and friends reacted to these losses, she stated that some of them were disappointed in her but she just kept going. With optimism and religious faith, she left it up to God. Speaking in Indonesian, she said:

“... Sebagai umat Islam kita harus yakin apa yang diberikan itulah yang terbaik buat kita . . . Kan keyakinan kita ke situ buk . . soal duduk atau tak duduk itu buk mungkin waktu itu belum izinNya. . . Itu adalah urusan yang Maha kuasa. Kita yakin dengan yang Maha Kuasa... soalnya bagaimanapun orang menjelek-jelekan kita, tapi Allah sayang ke kita, tidak akan mempan. Soalnya kalau ibu pedomani tadi .. . kalau 2004 saya duduk bukan karena suara terbanyak, sistemnya nomor urut. Kalau seandainya tahun 2009 berdasar nomor urut, saya belum tentu duduk. .. Karena kita bukan nomor urut satu. . jadi kita harus yakin ke situ...Makanya sekarang ini saya kan sekretaris PPP Tanah Datar Buk....Oooo bagaimana saya berbuat kalau dapat Caleg itu lebih bagus dari saya, kualitasnya, SDM. . . Pokoknya di atas saya yang saya inginkan. Jangan di bawah saya... Kalau kita saja, cuma kemampuan seperti ini... apalagi yang di bawah kita kemampuannya . . . soal yang duduk tidak duduk bukan urusan kita yang jelas bagaimana kita membesarkan partai terlebih dahulu...Jadi mungkin itu perbedaannya."

"... As a Muslim, I believe that God gives us what is the best for us. That is what we believe. If I won or lost, maybe it wasn't time for God to allow it. That's up to the Almighty. I have faith in God. No matter what other people say about you, God's love for you can't be damaged. If you noted before, in 2004, I won, not because I got the most votes, but because of my position (on the list of 
candidates). If they had used the list position in 2009, I might not have won because I wasn't first on the list. You have to have faith. So now I am the secretary of PPP in Tanah Datar. What can I do if other candidates are better than me in quality or abilities? The thing is, I want something above me, not below me. By myself, my capacities are what they are, much less the people below me. Winning or not winning is not my only problem. I have to try to promote the party first. So maybe that's the difference." (Interview with Respondent 4, 25/9/2012).

Respondent 4 also stated that she has always maintained a connection with the voters even though she lost in 1997 and 1999. She acknowledged that her target voters came from small villages (jorong) near her hometown. This area has been her priority since the area has 1500 people who are qualified to vote. She maintains this connection by visiting them on various occasions, such as at the end of the fasting month, when someone is sick or dies, or if there is a wedding. Speaking in a mix of Indonesian and Minang, she said:

"Yang saya inginkan adalah hubungan silahturami antara kita tak terputus selagi kita sehat wal afiat. Maka itulah yang saya lakukan buk. Sebelum dilantik saya sudah berkunjung . . . khusus untuk nagari di Jorong Andaleh Baruah Bukit Sungayang, bukan nagari nya tapi satu jorong itu, itulah yang kontinu tak putus-putus saya jaga hubungan silahturahmi. Seandainya ada yang sakit saya tetap akan usahakan kesana, seandainya ada yang meninggal saya akan kesana bersama pengurus kita, diisi amplop sebagai . . . Putih hati bakaadaan, putih kapeh dapek di lihat kan."

"What I want is that my good relationship with these constituents should go on for as long as I am in good health [and can do my job]. So, this is what I did, before I was even sworn in, I went to see them in Andaleh Baruah, Bukit Sungayang. Not to the nagari either, to this village. And I have continued this without interruption to protect the relationship. If someone is sick, I try to get there. If someone dies, I go with one of our management. I slip them an envelope. Pureness of heart is apparent; the quality of cotton is obvious." (Interview with Respondent 4, 25/9/2012). 
She went on to say that she pays attention to these voters without concern for whether they will choose her or not. She explained:

Iya bersimpati untuk keluarga tersebut. Itu tak terputus. Saya tidak tahu apakah ia orang PAN, PKS atau Golkar, PDI-P duluny, tetapi tidak ada dibedakan untuk Jorong Baruh Bukit itu buk."

“... I try to be sympathetic to their needs. That doesn't stop. I don't know whether they support PAN, PKS, Golkar, or PDI-P. I don't make any difference between the residents in Jorong Bukit Baruah." (Interview with Respondent 4, 25/9/2012).

Another strategy to get more votes used by respondent 4 was to campaign with a male candidate from her party. He was a candidate for the national parliament, not the local parliament. They handed out campaign items, such as T-shirts, party flags, brochures and other items. She described this in Indonesian:

"Jadi itulah perbedaannya buk . . kalau kita tak ingin menjual diri kita sendiri. Bagaimana untuk provinsi dan kabupaten itu, jadi ndak jalan sendiri buk kalau ingin membesarkan parta."

"... So that was the difference. If you are not willing to sell yourself ... what about the province and the regency? You can't go yourself if you need to promote the whole party," (Interview with Respondent 5, 25/9/2012).

Respondent 4 was confident that that she had held office for two periods because of her efforts to maintain a good relationship with her constituents and voters over a long period. She had not experienced any uncomfortable issues because she was a woman, even though she had been mocked at times, especially in the New Order era. At that time, members of the ruling party tended to try to ridicule members of other parties. As she stated in Indonesian:

“. . . Aaa cimeeh memang kita alami . . kalau dulu ada . . . kalau sudah duduk tentu mereka agak segan . . . Waktu dulu buk waktu Orde Baru . . . kalau saya pakai baju hijau itu akan dicemeeh . . .'kemana koncek ijau.' Setelah tahun 1999, tak ada lagi cemeeh yang demikian. Saya juga tak merasakan laki-laki itu menjadi sandungan untuk maju. Sebetulnya yang penting bagaimana kaum perempuan itu bangkit untuk maju, untuk berbuat yang sebaikbaiknya di tengah masyarakat. Yang kelemahannya kan perempuan 
sesama perempuan itu tak jelas, suka mengkaji kekurangankekurangan diantara sesama perempuan. Kita tak akan berhasil, ya kan..."

“... I've been mocked ... in the past. Once you're in office, they don't dare. Under the New Order though, if I wore a green dress, they'd say, 'Where are you going, Froggy?' After 1999, there was no more of that stuff. I have never felt that the men were an impediment to me. The important thing is for women to get up and go forward to do their best for the community. Their weakness is that the relationships between women are not clear; we like to discuss our shortcomings among ourselves. (If we do that) we can't succeed, can we?" (Interview with Respondent 4, 25/9/2012).

Another effort of respondent 4 to maintain the loyalty of her constituents is to maintain a small business producing cookies. Before becoming an MP, her business produced and distributed cookies to various areas, including Padang, the capital of West Sumatra. Now, however, because of her busy schedule in parliament, she bakes only seasonally, especially at the end of the fasting month and distributes the cookies to her constituents as part of a holiday gift to them. She uses this as a way to fulfil what she sees as her responsibility at this time of year. She explained in Indonesian:

"Gunanya saya hasil kue itu bukan untuk bisnis lagi. Cuma untuk sosialnya, setidaknya saya bisa beri paket untuk kader-kader saya satu setengah kilo per orang. Waktu hari raya Idul Fitri itu kita bisa laksanakan open house di hari raya dan tamu terbuka datang ke rumah. Yang datang mendapat amplop berisi lima puluh ribu ditambah kue kering. Nah itulah yang kita bagikan dari hasil kue kering itu. Kalau kita bawa honor DPRD untuk melaksanakan itu tak bisa buk. Bahkan kecendrungannya kawan-kawan kita di dewan ini, kalau dapat di hari lebaran itu jangan ada di rumah."

"I don't produce the cookies as a business anymore. They are just to hand out... I give a package of at least half a kilogram to each of my constituents. On Idul Fitri, we have an open house, and people come to the house. The ones who come get an envelope with 50,000 rupiah and the cookies. What I give out comes from my sales. My salary from the parliament couldn't cover that. My colleagues in the 
parliament tend to avoid this ... a lot of them are just not home on the holiday." (Interview with Respondent 4, 25/9/2012).

She continued that she has an obligation to celebrate the end of fasting month with her constituents by giving them something. As she said in Indonesian:

“. . Karena memang demikian tuntutannya . . Kalau saya itulah caranya buk, saya berharap dari bisnis kue kering ini . . . bagaimana kita bisa mencari dana untuk berhari raya dengan kader-kader saya. Kalau ditanya orang berapa untungnya dari usaha kue kering ini sekarang . . . saya tak bisa jawab . . saya bukan melihat ke system bisnisnya tapi bagaimana kita bisa mencari dana dan bisa berhari raya dengan kader."

"... This is an obligation. This is my way of fulfilling it. I depend on the cookie business for that. How else could I get the money to celebrate the holiday with my constituents? If anyone asks me how much I make from this business now, I can't answer. I don't look at the business side of it anymore. I just worry about how to get the money to celebrate with my constituents." (Interview with Respondent 4 25/9/2012).

Respondent 5 targets voters from her surrounding areas. As she is the daughter of a public figure, her voters mostly come from her extended family and members of her clan. Her strategy to get votes varied in the two elections she participated in in 2004 and 2009. She acknowledged that, in 2004, she approached the community based on its needs, while in 2009; she went door to door handing out T-shirts, uniforms, and calendars with her picture on them. She explained in Minang:

"Agak beda stek dengan tahun duo ribu ampek. Iyo awak bergerak membantu berdasar permintaan masyarakat. Kalau tahun duo ribu sambilan awak mulai door to door . . . soalnyo saingan ketat. . . selain menyiapkan baju kaus. Baju seragam dan kegiatan social...kito selalu buek kalender tiok tahun ... jadi kan konstituen ingek taruih. Iyoo mesti pandai-pandai. . . Yo awak kan maagiah beda-beda. Kalau iko jarang basobok . . double diagiah . . kalau acok basuo . . . sekian diagiah . . . pandai awak juo nan maatur . . , 
"It was a little different in 2004. I tried to help out based on what they said they needed. In 2009, I went door-to-door. There was a lot of competition in that election. I had t-shirts, uniforms. I went to social events. I make a calendar every year, so my constituents will remember who I am. You have to be smart about it. I give them different things. If there is someone I rarely see, I give them double. If I see them all the time, I give less (on a given occasion). You have to know how to arrange it." (Interview with Respondent 5 4/9/2012).

Respondent 5 keeps her voters by approaching them during campaign periods. For example, she has held a cattle race on her family property to attract constituents. She described this in Minang:

“O . . apo . . pacu jawi ... kan dalam pacu jawi tu ado inset dan hasilnyo, sekitar tiga jutaan tu disumbangkan ke mesjid, panitianyo konstituen awak. Awak mengeluarkan dana dan fasilitas arena tanah se nyo, itu sudah dua periode mode tu, tapi untuak bisuak ko ndak bisa lo lai...lahan untuk pacu jawi tu lah dipakai, dibuek bedeng, dipakai dek dunsanak untuk mengolah lahan."

"... Oh, the cattle race, in this race there is investment and profit. We gave about 3 million to the mosque. The members of the management committee were my constituents. We only had to pay for the race track. I've done this twice already. But I won't be able to do it again. The land we used for the race is being used for something else now. They built a shack for the workers there. My relations are farming it now." (Interview with Respondent 5, 4/9/2012).

Respondent 5 also used her father's influence to keep her constituents. She explained that her father is a trader with several stores and every year donates money as an obligation to the poor in the form of zakat (Islamic charity governed by religious law). She helped her father distribute this charity by delivering it to the poor herself. As she explained in Minang:

"Apa kan punyo usaho banyak. . badagang, sawah, ladangnyo banyak jadi zakat itu kami kumpulkan sekali setahun diagiah. Yo tetap rutin setiap tahun. Tiok tahun zakat diagiah . . . awak tu yang maantakan ka rumah-rumah . . . door to door tu kami antakan." 
"My father has a lot of businesses . . . he sells things; he has rice fields, dry fields. So we take our zakat and distribute it once a year. We do that routinely every year. Every year, we hand out charity, and I take it around myself from house to house, door- to- door." (Interview with Respondent 5, 4/9/2012).

She added that the amount people receive is 250 thousand rupiah, and 150 to 200 people are involved each year. If any of them die, they will be replaced by someone else who is entitled to receive this type of aid.

\subsection{Summary}

The politicians who took part in this study used various means to win a seat in parliament. There were differences and similarities in terms of their experience in politics. The support of the extended family received by several of the respondents was notable, although it was not universal. Some respondents also relied on their own resources that were separate from any family assets, to support their political career. Nonetheless, even when it was not possible for a respondent to use assets belonging to the family, they were all encouraged by family members, friends, colleagues, and their party. There was a general idea among the families of these politicians that it would be beneficial for the extended family and clan to have one of their members in local office. Similarly, the parties seemed to feel that these women would benefit them as well, and most of the respondents also reported doing their best to return this trust by supporting the party's aims and work. Additionally, these respondents generally relied heavily on the networks they had within their community and specifically tried to take advantage of the people they knew and the non-political organisations they were associated with. Chapter 6 below presents these issues from the point of view of local elites and members of the voting public. 


\section{Chapter 6}

\section{Female Politicians: Views of the Public}

This chapter reports the opinions of community leaders and voters toward female politicians. This chapter contains two major subsections. The first of these relates to the opinions of community elites. It is further broken into themes that emerged from interviews with these individuals. These themes include: the traditional roles of Minangkabau women; the relevance of these roles to modern politics; women as MPs; the 30\% quota for women; women in politics in Minangkabau society; and their support for female politicians. The second major subsection concerns the voters. It is also divided according to themes that emerged from the interviews and questionnaires used to elicit the opinions of these groups and addresses topics, including: the importance of having women in politics; the matrilineal system and its benefits for female politicians; considerations in choosing candidates; the performance of female MPs; politics as an appropriate field for women; and the trustworthiness of male and female politicians.

\subsection{Community Leaders}

In this section, the perspectives of five community leaders about female politicians in West Sumatra are discussed. These five community leaders have a range of backgrounds, education, age and occupations. Their backgrounds are described below in numerical order.

Community leader 1 (CL 1) is a former journalist in the local media in West Sumatra. He has written poetry and opinion pieces and has been active in the cultural community in the city of Padang. During the Reform Era when many new media outlets appeared, he decided to resign from his job as a journalist at Harian Umum Singgalang, one of Padang's daily newspapers. He then worked as a journalist for several new media outlets in Padang and Pekanbaru, in the province of Riau. In 2003 he became executive producer of B-TV in the 
town of Bukittinggi and finally became the head of a nagari in Pasia, a village in the Agam regency. His formal educational background is in accounting. He was enrolled in a Diploma program at a private college in Padang but did not complete his course because he was busy with his job as journalist. After working for several local newspapers and then in television in Bukittinggi, in 2004 , he became a farmer in his village and worked with the local community. In 2008, he ran in the direct election in Nagari Pasia, Ampek Angkek District, Agam Regency. There were three candidates, and he won the election on 9 March 2008. His close relationship with the community allowed him to beat the two other candidates, one of whom was the incumbent. In June 2012, he became chairman of the association of nagari heads in Agam [PerwanaPersatuan Wali Nagari Agam] for the period 2012-2015.

The nagari head (wali nagari) is a local leader in the context of traditional administration in West Sumatra. This position has always existed in Minangkabau including during the colonial era. Under Soeharto, a centralized system was put into place across Indonesia. The lowest level of government administration was the village level [desa] which was headed by a Lurah or village head. Decentralization following the Reform Era allowed West Sumatra to return to its original system of governance. The position of nagari head is parallel to the camat, who heads a district within an urban area. The nagari head is directly responsible to the head of regency (Bupati) as the camat is responsible to the mayor of a city.

Community leader 2 (CL 2) is referred to as a 'Buya' reflecting his status as a religious leader. His long experiences in Islamic teaching and proselytizing have allowed him to travel to many places including Mentawai, Papua, Malaysia and Pattani in the southern part of Thailand where there are Muslim communities. As a theologian, he often gives lectures and is invited to speak at religious and cultural conferences, seminars, dialogues and discussions. As a religious leader in West Sumatra, he also advises members of the public and several Islamic 
organisations such as the Council of Indonesian Ulamas (MUI - Majelis Ulama Indonesia) of West Sumatra and serves as Chairman of the Islamic Charity Board (BAZ - Badan Amil Zakat) of West Sumatra. He is also a community leader in the area where he lives, Siteba, Padang. His expertise in Islamic teachings and Minangkabau culture issues have allowed him to become a director of the Centre for Islamic and Minangkabau Study (PPI - Pusat Pengkajian Islam dan Minagkabau). He has also written several books on Islamic teachings and Minangkabau culture.

Community leader 3 (CL 3) is a Dean of the Faculty of Social and Political Sciences at a public university in West Sumatra. As a member of the Minangkabau ethnic group as well as a political scientist, he is interested in political participation in Indonesia and is familiar with the roles of and demands on politicians in the current political context. As an academic, he has taken part in meetings and hearings on social issues in West Sumatra in the local parliament. During these meetings, he has met with female MPs. Additionally, he had been an interviewer in the selection of women for a local election committee (KPU Komisi Pemilihan Umum Kecamatan) in the 2009 election. His experience as a dean has also made him familiar with the West Sumatran community and its views on political participation.

Community leader 4 (CL 4) is a cultural figure in West Sumatra. He was a committee member of the Arts Board of West Sumatra (KKSB - Dewan Kesenian Sumatra Barat) for two periods. His is best known as a teacher of martial arts and randai. Randai is a traditional dramatic form of West Sumatra that combines martial arts, drama, dance and traditional music. He did not complete elementary school but studied martial arts from the age of nine and studied Minangkabau proverbs and traditional rhetoric from the age of 13 . He is also a traditional leader or head of his clan (Datuk Penghulu) of his extended family in the town of Padang Panjang and holds the title 'Datuak Katik Rajo Mangkuto.' His expertise in martial arts, randai, Minangkabau culture, and flute playing has allowed him to 
be a guest lecturer at universities in West Sumatra, and he was twice invited to University of Hawai'i at Manoa in the US, first in 2000-2001 and again in 2011. He was similarly invited to teach at the National Academy of Traditional Arts (ASWARA) in Kuala Lumpur, Malaysia, in 2009-2010. Since 1976, he has been an advisor to many randai and martial arts groups in Padang and also teaches and advises on traditional rhetoric in Padang.

Community leader 5 (CL 5) plays multiple roles in the community. She holds a doctorate in Agriculture and is a lecturer at one of Padang's public universities. In addition, she is a $13^{\text {th }}$ generation descendant of the king of Pagaruyung who once ruled the Minangkabau people from the village of Pagaruyung in the regency of Tanah Datar. She holds a royal title, Yang Dipertuan Gadih Pagaruyung, and is the current chair of a women's organisation in West Sumatra, acting as a Bundo Kandung in this context. The term of Bundo Kanduang has two different aspects: indicating the position of a woman as a leader in her extended family and in a comparable position in the public realm of Minangkabau society. In addition to her academic and cultural activities, community leader 5 is a wellknown poet and writer on Minangkabau culture. The background of these five community leaders is contained in Table 3.

Table 3: Background of Community Leaders Interviewed for this Study

\begin{tabular}{|c|c|c|c|}
\hline $\begin{array}{l}\mathrm{N} \\
\mathrm{O}\end{array}$ & $\begin{array}{l}\text { Community } \\
\text { Leader (CL) }\end{array}$ & Background & Occupation \\
\hline 1 & $\begin{array}{l}\text { DOB 29/8/1963 } \\
\text { Widower }\end{array}$ & $\begin{array}{l}\text {-Incomplete diploma of } \\
\text { Economics. } \\
\text {-Long experience as writer, } \\
\text { poet. } \\
\text {-Former journalist in local } \\
\text { media in West Sumatra } \\
(1983-1998) .\end{array}$ & $\begin{array}{l}\text { Head of Nagari } \\
\text { Pasia, Kabupaten } \\
\text { Agam since } 2008\end{array}$ \\
\hline 2 & $\begin{array}{l}\text { DOB 16/8/1936 } \\
\text { Married }\end{array}$ & $\begin{array}{l}\text {-Bachelor's degree in } \\
\text { Education. } \\
\text {-Theologian. } \\
\text {-Writer in Islamic } \\
\text { proselytizing. }\end{array}$ & $\begin{array}{l}\text { Deputy advisor of } \\
\text { Council of Islamic } \\
\text { Ulama (MUI), wes } \\
\text { Sumatra Chapter } \\
\text { since } 2008\end{array}$ \\
\hline
\end{tabular}


-Former chairman of Islamic Charity Board (Badan Amil Zakat-BAZ)

West Sumatra since 2008.

3 DOB 6/1/1965

Married

4 DOB 18/81950

Married

5 DOB 31/8/1947

Married

Two children
-Bachelor's degree in Art and Social Sciences, (1987).

-Post graduate degree in

Sociology (1992).

-Lecturer at Andalas

University since 1989.

-Incomplete elementary

school education.

-Studied martial art and randai from the age of nine. -Studied traditional rhetoric and Minangkabau proverbs from age of 13.

-Head of his clan with title

Datuk

Katik Rajo Mangkuto.

-Doctor of Agriculture, 2007

-Writer and poet

- Head of Bundo Kanduang

Organisation of West

Sumatra

- Thirteenth generation descendant of the King of

Pagaruyung.
Dean of Faculty of Social and Political Sciences, Andalas University 20082012

- Guest lecturer at national and international universities. -Known as a humanist in West Sumatra

Lecturer at Andalas University

Source: Interviews conducted by the author.

Table 3 shows that there are a number of differences in the background, occupation, and age of these community leaders. These differences are reflected in their views on the role of women as politicians in West Sumatra. These leaders were interviewed about their opinions on the traditional roles of Minangkabau women, the compatibility of women's traditional roles with political activities, their opinion on the $30 \%$ quota for women in public office and the extent to which they support women's participation in politics. These opinions are presented below. 


\subsubsection{The Traditional Role of Minangkabau Women}

The five community leaders agree that women in Minangkabau have a specific role in their extended family. Their views on this role include that women have a strong position in their clan; that women are central and dominant in their extended family; that women guarantee the legal rights of children; that children are socialized by women; that women are role models; and also that women are specifically referred to in Minangkabau traditions and philosophy. One informant said in Indonesian:

“. . . Peran kaum perempuan di Minangkabau itu sangat penting, sejak dalam politik rumah gadang, lingkungan kaumnya di rumah gadang...kaum perempuan sebetulnya memiliki peran yang bagus yang dominan. Dalam artiaaann semua keputusan . . . itu selalu kaum laki-laki itu akan konfirmasi ke kaum perempuan. Konfirmasi, bahasa minangnyo dipaiyoan ka kaum perempuan.”

"... The role of women in Minangkabau is very important; this goes back to the politics of the extended family, within the clan in the traditional [multi-family] house. Women actually play a strong role and are dominant. When decisions are made, the men have to confirm everything with the women. That idea of confirmation, we say in Minang, is that the women have to "say yes' to everything." (Interview with CL 1, 29/8/2012).

The customary roles of Minangkabau women are described in traditional literature. One informant discussed this in a mix of Indonesian and Minang:

“... . Perempuan di Minangkabau seperti disebutkan dalam bahasa adat; Umbun puruak pegangan kunci, berarti sebagai bendahari, pemegang kekayaan perempuan. . .kan berkuasa dia itu. . . haa siapa lagi dia ... Unduang-unduang ke Madinah. . Madinah kan tempat ziarah. . . tempat yang baik. . jadi payung kesana restunya itu dari ibu. Haaa ya ndak . . . Limpapeh rumah nan gadang, limpapeh itu kan yang mengindahkan . . . Sumarak di nagar I . . . kan peran itu . . Bagaimana negeri kalau tak punya perempuan . . . Kasturi tuladan kain . . . itu kan patron, suri .. . kalau kita menjahit harus ada surinya. . .harus ada patronnya. . .Haaa sesuai dengan ajaran agama. . .Annisa Imanu billah. . .perempuan itu tiang 
sebuah negeri . . kalau dia baik. . baik pula negeri itu . . kalau buruk maka buruk pula negeri itu ..."

“. . Women in Minangkabau are as they are described in the language of traditional law and custom: 'Umbun Puruak pegangan kunci' means that women control the wealth, they have the power. Who else if not them? 'Unduang-unduang ke Madinah' is because Medinah is a place of Islamic pilgrimage, a good place. So your umbrella protecting you there is the consent of your mother to go. 'Limpapeh rumah nan gadang', well, butterflies are pretty. Women seem like butterflies [limpapeh] in the traditional house. 'Sumarak di nagari' that's their role, to shine in the community. What would happen if there were no women? 'Kasuri tuladan kain,' that's a pattern, if you sew, you have to have a pattern, a guide. This is in line with religion. 'Annisa Imanu billah, 'women are the pillar that holds up the community. If they are good, then the community is good. But if they are bad, the whole community is bad," (Interview with CL 2, 15/10/2012).

This respondent went on to say that a woman's role in the traditional context can be extended into the modern political context:

“. . . Nnnah itu salah satu peran perempuan Minang. . . Kasturi tuladan kain. . . sebagai tauladan. . . Masya Allah. . . Naah kalau begitu perempuan diletakkan di posisi sedemikian rupa. . . peran yang begitu kenapa tidak bisa duduk di DPR?"

"... Well . . . that is one of the roles of a Minang woman. 'Kasturi tuladan kain' means she is a role model. My God. Now, in that case, since women are already in that position, have that role, why should they not be in parliament?" (Interview with CL 2, 15/10/2012)

Another respondent indicated that the traditional role of Minangkabau women is contextual. He explained in Minang:

“. . . Nan padusi Minang ko mempunyai peran batampek-tampek, ndak sumbarang sajo do. Katiko rang rapek di ateh balai atau di ateh rumah, laki-laki sajo. Katiko la masuak ka wilayah perempuan, ka wilayah Bundo Kanduang ... nyo baru diimbau ru ... kalaupun ado nan agak kritis Bundo Kanduang ko, kan ado juo tu .. . dek ambo basobok. .. Duduak di pintu biliak." 
“. . . Minangkabau women have contextual roles. It isn't random. When there is a meeting at the town hall or traditional house, it is only attended by men. But when the discussion gets around to women's issues, the business of Bundo Kanduang. They will be called. Nonetheless, there are people who are critical of the Bundo Kanduang role, I have found, when she just sits in the doorway (and doesn't participate).” (Interview with CL 4, 15/10/2012).

Moreover, the respondent explained that, besides taking part in meetings when they are needed, women also play a part in wedding ceremonies. As she said in Minang:

“... Sudah tu dima saat kalua ciek lai? Rajo datang rajo Mananti, Puti datang Puti menanti, mukasuiknyo apo? Katiko rombongan anak daro itu datang untuk pai manjalang rumah mintuonyo . . . ndak lo kami laki-laki bafungsi, nyo memang inyo lo lai . . Bundo kanduang-Bundo Kanduanglo lai . . . Hei japuiklah minantu ka laman tu ha ... kan segala macam baserak bareh kuniang . . nan urang laki-laki ndak lo sato lai do. Nyo lo di situ lai. “

“. . . After that, when will the women take part? 'When a king comes, a king waits; when a prince comes, a prince waits'. What does it mean? When the bride arrives to go to her in-laws house, then men have no place. It's all the women, the Bundo Kanduang. They meet her in the yard, they're the ones scattering yellow rice. The men have no part in this. It's the women." (Interview with CL $4,15 / 10 / 2012)$.

According to this informant, the traditional role of Minangkabau women does not extend to all situations. This is because the nature of women and their ordinary behaviour have to be balanced. He described this in Minang:

“......Jadi bakutiko. A nan bakutiko tadi digambarkan; Labuah panjang liku baliku, labuah kaciak candai tajelo, bapaga pudiang aia ameh. Pudiang geni barumpun-rumpun, pudiang hitam babatang-batang. Raso ka tinggi bapangkasi raso, ka randah baanjuangan. Aa tu ... ba bituan ... Boleh anak gadih ka muko . . . buliah urang parampuan ka muko, pi raso ka tinggi, ria samaah . . . aa inyo labiah gagah pado urang . . . bapangkeh ma. . . Ndee sombong na bantuak ko ma nak . . takuak an agak saangin . . . ka 
balakang stek jaan manilongak bana . . talampau takuik bana lo . . . raso ka randah baanjuangan. . . bantuak anjiang mangapik ikuanyo ... urang ndak taka itu do nak. . . ka muko la stek,. nampak an juo la awak jo urang... Ndak pernah ndak seimbang."

"So there is a place ... I explained that place before. 'The long road twists and turns, the short road is lined by decorative croton plants. Geni crotons grow in clumps, black crotons grow in groves. If they are tall, clip them; if they are low, stake them up'. That's how it is. Young girls can come to the forefront. Women can do this. But if they're getting too big, it's better to hold them back. That looks better to people, cut them back. It's a kind of conceitedness. They should just step back a little, but not too much. They shouldn't be too scared. If they're small, prop them up. Let them come forward a little so people can see them. It's never out of balance." (Interview with CL 4, 15/10/2012).

The Minang saying used by this respondent describes how women in Minang are positioned in the middle and have a balanced situation. Another respondent noted that the traditional role of Minangkabau women can be viewed in terms of rights and ownership. Women are considered to be the owners of communal property because they control and oversee the assets of their extended family. Additionally, women have the right to traditional titles and their clan name. Titles and status of this kind are inherited and come from the maternal line, passing from grandmother to mother to daughter.

\subsubsection{The Relevance of Women's Traditional Role to Politics}

Various opinions regarding the relevance of women's traditional roles to the modern political domain were visible in the community leaders' answers. Their general view was that women in Minangkabau have a prominent role in their extended family but this does not extend to the public arena. Nonetheless, one respondent did feel that because of their dominant role in their extended family, women have the ability to enter public space, including politics.

This respondent said in Indonesian: 
"Peran tradisional perempuan Minang itu sesungguhnya memberikan keamanan dan kenyamanan bagi dia dan keluarga besarnya. Jadi secara budaya perempuan Minang sudah ditempat yang nyaman...mereka memiliki hak untuk mengelola harta pusaka tinggi sehingga tidak resah lagi untuk menghidupi anak bila suami pergi . . . Karena secara budaya perempuan Minang sudah ditempat yang aman, nyaman, maka peran tradisional tersebut memberi ruang kepada perempuan untuk berpolitik. Persoalannya tak semua perempuan berminat dan memilih politik sebagai lahan atau bidang yang ditekuninya..."

"The traditional role of Minang women provides security and comfort for their extended family and for themselves. So culturally, women are in a comfortable position ... they have the right to manage family property, so they do not have to worry about how to support their children if their husband leaves them. Because culturally Minang women have a safe, secure position, their traditional role gives them an opportunity to enter politics. The problem is that not all women are interested in and choose politics as their career. .." (Interview with CL 5, 29/8/2012).

Similarly, another respondent noted that women or mothers in Minangkabau serve as role models. They set an example for their children through their activities in the public space, including in politics. Another opinion was that there is relevance in the traditional role of Minangkabau women for their activities in politics, but only under the condition that the woman is established economically and can finance her candidacy. Nonetheless, according to this community leader, not many established women want to enter politics.

On a slightly different note, another respondent said that the relevance of women's traditional roles and their position in Minang do not have a direct correlation with their involvement in politics. This individual explained in Indonesian:

"Apa namanya . . eеee . . itu kan sudah masuk di wilayah public, wilayah yang kita diskusikan tadi wilayah domestic . . naah khusus untuk perempuan Minang, yang menjadi modal dia adalah eksistensi dia di tingkat kaum atau di tingkat sukunya . . . artinya eksistensi itu sebetulnya yang menjadi modal . . . kan gitu. Nnah 
sebab itu tidak akan menjadi suatu hal yang punya relevansi bahwa dia memiliki peran dominan di bidaang politik atau public. Tidak ada korelasi langsung . . . itu kan sebetulnya bisa kita amati dari anggota DPRD perempuan di Sumatra Barat. Itu mereka tidak dominan. Tiidak bisa mempengaruhi sebagaimana mereka bisa mempengaruhi keputusan di tingkat domestik."

“...Well . . . this comes into the public arena; what we discussed earlier was the domestic space. For women in Minang, their capital is in their position at the extended family or at the clan level. That position is an asset, you know. Because that is one thing that is relevant to them playing a dominant role in politics or in the public realm. There is no direct correlation though. That's what you see among the female members of the regional parliament in West Sumatra. They do not dominate. They can't influence decisions the way they influence them at the domestic level." (Interview with CL $1,29 / 8 / 2012)$.

Another community leader agreed that since traditional women's roles in Minang are relative and apply only in certain contexts, they should not occupy a 'front' position. As he said in Minang:

“Aaa lah...per 'ampu an' atau perempuan ko iko dalam tugasnyo di Minangkabau hanyo duo sajo . . . ma maapoannyo. . . artinyo bamain kapeh jo banang dan menurut kato suami; Aa ko makonyo urang paralu batanyo ka tradisi yo, bahwa padusi Minang itu karajo nyo bamain kapeh jo banang. Tamasuak kambang bandohari, itu ia seorang penasehat ahli, padusi nyo . . . bamain kapeh jo banang, itu dia orang yang tidak ke muka, atau di forum ... di belakang layar, dia orang ahli juo. Aaa . . tu nan dikecek an bamain sabuik bamain kapeh jo banang, menurut kato suami. Jadi nan kamuko suaminyo, tapi di inyo di belakang sebagai pemikir yang cerdas. Ini sesuai dengan hukum adat yang berlaku dan merata pada saat itu . . dan sesuai dengan aturan Islam . . ."

“... Women are called 'perampuan,' per 'ampu' an (where 'ampu' means 'capable' or 'functional'). So women can be seen in terms of their function. In Minangkabau, there are two of these only. This means they 'handle the cotton and the thread' and they obey their husband. So we need to look to tradition to see that women should 'handle cotton and thread.' This includes Kambang Bandohari (a character in the legend of Cindua Mato), who was an expert advisor, that woman. But she kept to 'the cotton and the thread,' she didn't 
put herself forward. She stayed behind the scenes. She was an expert though. That's what it means to 'keep to the coconut husks, to handle the cotton and thread' and obey their husband. So the one who presented to the public was the husband, but she was in the back-ground as the brains. This is in accord with traditional law and was the way at the time. And this accords with the principles of Islam." (Interview with CL 4, 15/10/2012).

The statement shows the view that a women's place is at the back, not in public. Another community leader also mentioned that a woman should follow her husband as indicated by Islamic teachings but he said it was not a problem for women to enter politics as long as their husband allowed them to.

\subsubsection{Woman as MPs}

Regarding the performance of women as MPs and whether women are better than men in this role, most community leaders did not see a difference between female MPs and male MPs in terms of their performance in parliament. Respondents generally had the opinion that women are not much better than men as politicians. Female politicians, they felt, do not have much influence in parliamentary decisions but are much affected by the political interests of their political party just as male MPs are. An interesting view presented by one respondent was that it was not unusual to see women in politics, especially in the Indonesian political context. This is because the situation in Indonesia gives them opportunity and most of them are just looking for a job. He said in a mix of Indonesian and Minang:

"Jadi undang-undang pemilu menyebabkan masing-masing partai ini menjadi sedemikian rupa menggenjot Caleg perempuan ... ya yang penting asal dapatlah. Kebetulan terus terang ambo mancaliak. . . mungkin umum sifatnya di Indonesia maupun Sumbar. Sebetulnya untuk menjadi anggota dewan itu kan bukan dalam pengertian aktualisasi diri dalam pengertian Teori Maslow ya . . . orang yang sudah selesai kebutuhankebutuhan primer kemudian dia ingin do something. . . melakukan sesuatu. Ingin mengabdi . . ya orang yang memiliki visi kenegerawanan atau orang yang mengembangkan daerah 
atau sebagainya . . tapi ketemu dengan job seeker . . adalah orang yang sudah sekian lama aktif di Ormas, ikut ini, ikut itu . . . kebetulan diantaranya mereka terpilih."

“. . . So election law requires that each party present female candidates to the extent that they do. The important thing for the party is to have female candidates on their list . . . Frankly, I have seen that . . . this is probably common in Indonesia and in West Sumatra . . . becoming an MP is not self-actualization like in Maslow's theory ... People who have fulfilled their primary needs, then they want do something, to serve. You do get people who have a vision of the state or people who want to develop their region and so forth, but you see job seekers, people who have been active in organisations for some time. They do this and that, and it happens some of them might be elected." (Interview with $\mathrm{Cl} 3,14 / 9 / 2012$ ).

When asked about why there are significantly fewer female MPs than male ones and how they compare, one respondent said that women MPs are limited by cultural values in this area. He said in Indonesian:

"Yaa . . sebab begini. . . perempuan Minang juga terikat dengan yang namanya nilai-nilai adatnya. Secara tradisi tidak ngomong di depan ... Naah itu juga sebetulnya ketika dia masuk ke wilayah public katakanlah di sini wilayah politik modern atau katakanlah komunitas yang lebih besar. Itu dia juga terikat dengan nilai-nilai yang ada di dalam dirinya. Nilai itu umpamanya; sopan santunnya, dia tidak bisa terlalu keras, tidak bisa ngotot. Dia tidak bisa Ngg . . . apa mempertahankan pendapatnya secara apa namanya .. . secara tegas gitu . . . itu . . itu sebenarnya dalam amatan yaa. Banyak orang sebetulnya bisa mengamati hal seperti itu . . . dimana-mana anggota DPRD perempuan itu tidak dominan, tidak terlihat eksistensinya sebagimana dia memiliki eksistensi di wilayah komunitasnya."

“... Well, it's like this . . . Minang women are bound by the values of traditional law and custom. Traditionally, they are not supposed to speak in public. So when they enter the public arena, maybe modern politics or the wider community, they are still bound by the values they have internalized. These values include, for example, respectable behaviour. She shouldn't be loud, shouldn't insist. She can't . . . uh, defend her opinion by, you know . . . A lot of people have observed this, female members of the regional parliament are not dominant, you don't see them the way you see them in the community." (Interview with $\mathrm{Cl} \mathrm{1,30/8/2012).}$ 
This respondent was then presented with the fact that, in the early 20th century and the colonial era, many women from West Sumatra were active in the public realm. These included Rohana Kudus, the first female journalist in Indonesia and founder of the Soenting Melajoe newspaper and home industry for women in Bukittinggi; Rangkayo Rasuna Said, a heroine against the Dutch colonials in West Sumatra; and Rahmah El Yunusiah, founder of the Diniyah Putri Pesantren, and Islamic boarding school for girls in Padang Panjang. All of these women, according to this respondent, went against tradition and displayed unconventional thinking. As he explained in Indonesian:

"Kalau kita lihat di tokoh-tokoh penting kaum perempuan Minang .. . mereka sangat dominan di bidang tertentu, contohnya Rohana Kuddus, dia sangat dominan di dalam wilayah yang dia perjuangkan gitu . . . atau juga Rasuna Said . . . Dia sangat bagus gitu yaa ... tapi kalau kita lihat dari contoh-contoh yang demikian itu sudah sangat langka sebab dia sudah melawan tradisinya... . tradisi adat Minang itukan perempuan tidak ngomong di depan artinya dia melawan sebetulnya nilai-nilai yang ada di dalam dirinya . . yang ada di dalam budayanya. Makanya yang muncul perempuan yang sangat dominan di Minang itu karena dia memang melawan tradisinya."

"If you look at these important Minang women . . . they were very dominant in certain areas, for example Rohana Kudus, she was very dominant in her own field. The same with Rasuna Said. She was great. But you can see that examples like this are very rare because these women go against tradition. The Minangkabau tradition is that women do not put themselves forward. This means women [like this] are going against the values that they hold, that exist within their culture. So, when you get a woman who is very dominant in Minang, it is because she is going against tradition." (Interview with CL 1, 30/8/20120).

He went on to explain that even though women in Minangkabau do not traditionally come forward in public, they are often very forceful within the context of the extended family. He described this in Indonesian: 
“. . Contohnya gini. Ninik mamak. Katakanlah ninik mamak atau penghulunya lah, biasanya penghulu kaum . . . Biasanya penghulu ini dalam sebuah kaum, biasanya adik atau kakak perempuan. Naah kalau umpamanya si laki-laki ini tidak memperhatikan keponakannya yang ada di rumah perempuan ini, mungkin dia abai . . . atau dia berusaha menggadaikan harta pusaka, atau dia memanfaatkan atau memproduktifkan harta kaum . . . si laki-laki atau mamak ini membawa harta tersebut ke rumah istrinya. Perempuan sangat berani ngomong. Dia bisa secara tegas dan berani mengatakan ke kakak atau adiknya bahwa apa yang dilakukan itu tak benar. Bahasanya bisa seperti begini '... Sebagai mamak tuan tak batua dohh . . Kami ndak tuan caliak do, bini tuan se nan tuan paratian.' Nnah itu bisa seorang perempuan Minang bisa bicara seperti tu . . walaupun jabatannya penghulu ... Nnah itu Itu kan keberanian itu. Artinya kembali ke eksistensi perempuan Minang di wilayah domestik gitu..."

“... Take the example of the maternal uncle. Let's say he is the head of the extended family . . . usually, the head of an extended family has older or younger sisters. Now if, for example, this man doesn't pay attention to his nieces and nephews from these sisters. Maybe he ignores them or he tried to mortgage family property or he takes family assets for his own use, if this man, the maternal uncle, takes family assets for his own wife, the woman will have a lot to say. She will assertively and firmly tell her brother that what he is doing is improper. It will go something like this: 'As the uncle, you are doing wrong, you don't pay attention to us, you only think of your own wife.' Now, a Minang woman can say things like this, even if the man is head of the extended family. This is when they can be assertive. This comes back to the role of Minang women in the domestic realm." (Interview with CL 1, 30/8/2012).

One community leader felt that most female MPs are affected by the interests of their political party. They cannot implement their own ideas because they are under the control of the party. Another community leader, however, believed that both male and female politicians can work together, but the important thing is their personality and which one will take responsibility. Another community leader likened an MP to a chameleon. He said in Minang:

“... Bondong aia bondong dadak .. yo kama urang kama inyo. Iyoo itu kenyataan. Ba a bitu, secara keseluruhan laki-laki dan perempuan 
dek awak di Minang ko ado namonyo . . . tabang sapulun inggok sacakap, malompek basitumpu ... tabang sapulun, inggok sacakap, salapiak duduak sajamba makan. Malompek basitumupu samo sasaran pikiran awak, dek karano awak lah dibaonyo sato dibao kampanye misal . . kan la samo dasar pikiran ideology la samo ... tabang sapulun kama nyo pai awak la pai lo, inggok sacakam, dima nyo baranti awak la baranti lo . . . Manuruik taruih . . salapiak duduak dalam etongan awak samo. . . apapun awak dibao taruih. . . salapiak dudu. A nan sajamba makan awak ndak tahu lai . . Artinyo kutiko tibo di nan lamak anyo lah mempunyai hasil tentang itu .. . nan awak nan manolong ko kan tingga se lai ndak takana lai ..."”

"... When the water rises, the flotsam rises. Where people go, they (the politicians) go. That's how it is. Overall, our Minang men and women are referred to like 'They fly in formation, they perch in unison. When they jump, they have a place to push off . . . they fly in formation, they perch in unison, and they sit on the same mat and eat from the same platter'. 'Jumping with a place to push off' means they have the same way of thinking as us because we took part in the campaign, for example. They would have the same thinking, the same ideology, right? 'Flying in formation' means where they go, we go. 'Perching in unison' means where they stop, we stop. We follow them. 'They sit on the same mat' so they're the same as us. Whatever one does, we're carried along. 'They sit on the same mat' but when it comes to 'eating from the same platter' who knows anymore. In other words, when it comes to something profitable and there is some result from it, we helped them get it but they leave us behind and forget about us." (Interview with CL 4, 15/10/2012).

\subsubsection{The 30\% Quota}

Most community leaders said that the $30 \%$ quota for women in the current election law, which obligates every political party to have at least $30 \%$ of their candidates be women, is not important. Several suggested that the $30 \%$ quota underestimates women as politicians, and there is no reason not to have more female candidates than that. Another respondent felt that the quota is based on a male perspective. As he said in Indonesian:

“. . . Ya itu sebetulnya bukan dominan perjuangan perempuan, tapi itu aaa ... apa namanya . . cara pandang politik laki-laki . . Dia melihat bahwa kaum perempuan memang memiliki suara terbanyak 
... Iyaa ... iyaa pemilih lebih banyak dalam konteks pilihan politik, justru perempuan lebih taat memakai suaranya."

"... Well, actually, the $30 \%$ quota is not purely an effort of women, but that's, what do you call it, the political perspective of men ... They see that more voters are women. They realize that women are potential voters. In the context of political choice, women voters are more likely to use their vote." (Interview with CL 1, 29/8/2012).

Another respondent argued that the $30 \%$ quota for women is not important. She explained in Indonesian that it would be better to let candidates emerge naturally:

“. . Tak ada guna quota . . Justru menghambat karena terkesan dibatasi sampai 30\% saja . . yang penting kapasitas Caleg perempuan itu . . . Apakah dia layak dipilih dan menjadi anggota dewan mesti dilihat kemampuan dan kapasitasnya."

“. . . Quotas are useless. They are just impediments because they give people the impression that women are limited to only $30 \%$. The important thing is the abilities of these female candidates. To know if they are qualified to be elected and serve as a member of parliament, you have to look at their abilities and capacity." (Interview with CL 5, 29/8/2012).

Similar to the opinion above, another community leader said that it would be better if there were no $30 \%$ quota because the quota underestimates female politicians and shows that there is no appreciation of female politicians. As he said in a mix of Indonesian and Minang:

“. . . Ambo tak ingin diprosentasikan tapi dibebaskan saja. Kapan perlu tujuh puluah porsen dikeluarkan dek anu . . . tapi memang fakta sosial bahwa daya saing perempuan memang belum seperti laki-laki. Itu fakta . . . ini kan maksudnya untuk mempush, supayo adolah keseriusan dari partai untukjuga merekrut calon-calon dari perempuan. Untuk mencukupkan itu dia menurunkan standard. . . Standar diturunkan mungkin jam terbangnya, dia ingin yang campin, yang mantap penampilannyo, pemikirannyo yang bernas . . Segala macam . . tapi karena untuk memenuhi kuota diturunkanlah standard."

“... I don't think we need to set a percentage, it should just be open. When necessary, the seventy percent will be . . . but it is a social 
fact that women's ability to compete is not like men's. That's fact. (the quota) is intended to push the parties so they will seriously recruit female candidates, but to fill that quota, they lower their standards. They want ones who are competent, who are established, who have ideas, all kinds of things, but to fill the quota, they have to lower their standards." (Interview with Cl 3, 14/9/2012).

These respondents felt that it might be better to improve the quality of female candidates through education, social institutions, and experience in governance, rather than through a quota. This would be a more beneficial approach and would encourage women who were genuinely interested in politics to take part.

\subsubsection{Women in Politics in Minangkabau Society}

As community leaders in their areas, most of the respondents recognized that discussion about women in politics overlapped with their fields of interest. They did note, however, the intensity of discussion on this issue is dependent on the situation and occurs mostly during campaigns and elections. Discussion about female politicians, according to one respondent, has not been unusual in the Minangkabau context. During recent elections, it has been common for people in local areas to see women as viable candidates. This respondent explained in a mix of Indonesian and Minang:

“. . . Iyaa, ada mendiskusikan caleg perempuan, tapi tema pembicaraan tak ada yang pro kontra ... Cuma ada omongan yang seperti ini, 'si An la jadi calon lo nyo . . . la ba partai-partai lo nyo kini.'Aa gitu . . tapi tidak dalam celetukan konotasi negatif."

"... Well, we did discuss the female candidates, but the discussion did not focus on pro and cons ... . We just said things like, 'So and so, she's a candidate now. She's involved in the party now,' and so on. But there was nothing with any negative connotations ...." (Interview with CL 1, 30/8/2012).

He then described how members of the public in his area were invited to a celebration by the female candidate at which she announced she would be running in the 2009 election. The invitation involved about 60 people and the leaders of 
the local community whom she asked to support her in the election campaign. The guests had no negative impressions from this as it is common to receive and fulfill invitations during the election season in West Sumatra.

Another community leader mentioned that he and his colleagues have discussed female politicians, but these conversations were not in depth. He noted in Indonesian:

“. . . Belumm. Belum menjadi perhatian ya kiprah-kiprah perempuan di politik dan memang alam bawah sadarnya... . kesehariannya mereka ndak impress, ndak terkesan dia dengan keberadaan politisi perempuan ... Aa jadi ndak ada apanyaa ... larut aja dia dalam dinamika itu ... Sekarang apa isu yang menarik di Sumbar misalnya ... ndak ada politisi perempuan yang ngomong ... kalau ada yang ngomong pasti laki-laki."

". . . There is not as yet much attention paid to the activities of women in politics; it is more unconscious. They aren't very impressive. The existence of female politicians is not very impressive. There's nothing, they just get caught up in the dynamics. Now whatever is an interesting issue in West Sumatra, no female politicians have anything to say about it. If anyone says anything, it's the men." (Interview with Cl 3, 14/9/2012).

He then continued that, on one occasion during the election and campaign period, some of his colleagues at the university did hold a seminar about female candidates, their track records, their capacity building and also voter education. This was not a routine event, however, as elections take place only every five years.

Another informant said that he seldom discussed female politicians with his colleagues and journalists, but during the campaign period he sometimes gave his opinion and an overview of women in the public sector including, women in politics. He stated in Indonesian:

“... Ada mendiskusikan tentang perempun di sector public, dengan beberapa jurnalis. Isi diskusi membicarakan fenomena posisi perempuan kalaupun duduk di DPRD pun cendrung menjadi pengikut, karena mereka tak mandiri." 
". . . I have discussed women in the public sector with several journalists. The discussion centered on the phenomenon of the position of women. Even when they are in the regional parliament, they tend to be followers because they are not independent." (Interview with CL 2, 15/10/2012).

Another respondent, as the head of her extended family, mentioned that the people in her environment did not talk much about women in politics. She has been asked by women in her extended family about which candidates would be better to vote for. In her role as an advisor in her extended family, she suggested that it would be better to vote for a person based on their capabilities and approach to the community. She explained in Indonesian:

"Tidak terlalu, mereka hanya membicarakan ketika akan Pemilu saja, itupun lebih karena mereka bertanya siapa sebaiknya yang akan dipilih. Biasa mereka bertanya karena sehari-hari komunitas kita tidak terlalu tahu dan kenal dengan orang-orang politik... lebih banyak berada di lingkungan pedagang, petani, bukan orang politik. Jadi saat mereka bertanya biasanya kita akan mengarahkan untuk memilih orang yang ada hubungan dengan kita, cendrung berdasarkan kedekatan atau kenalan. 'Lebih baik orang yang sudah kita kenal, sesuku dengan kita yang dipilih. 'bukan karena ia perempuan atau laki-laki nya tapi karena orang yang kita kenal mungkin lebih bertanggung jawab dengan amanah yang akan dipegangnya."

" . . . Not really, they only talk [about political candidates] before the election. Even then, it's more because they want advice about who to vote for. They ask me because the community doesn't know much [about the candidates]. They know people in business and farmers, but not politicians. So when they ask, usually I will direct them towards someone who has a relationship with us. I tend to base it on closeness or the fact that I know them. 'It's better someone we know, that we vote for someone from our clan,' I say, not because they are female or male but because someone we know may be more responsible using the authority they will have." (Interview with CL 5, 29/8/2012). 


\subsubsection{Support for Women in Politics from Community Leaders}

All of the community leaders supported the participation of women in politics. The form of their support differed, however, depending on their role as a leader in their field. As the head of a nagari, this community leader stated that he supports and promotes all of the aspirations of people in the nagari, including women who are involved in politics. He stated in Indonesian:

“. . . O ya sekarang. . . kalau kita bicara tentang kondisi moderen, sekarang tak ada lagi sesuatu yang dianggap negatif ketika masuk ke wilayah politik. Dalam Pemilu 2009 saya melihat ada caleg perempuan yang juga melakukan kegiatan seperti caleg laki-laki. Iyaaa. . . artinya perempuan ini melakukan hal sama dengan lakilaki. Artinya dia tak harus sungkan, bahwa sebelum maghrib sudah harus di rumah..."

"....Well, right now... if we consider the modern situation, there is nothing negative about women entering politics. In the 2009 election, I saw women candidates who as acted like the male candidates. That is, they did the same things as the male candidates. They did not have to hesitate . . . they didn't have to rush home before the evening prayer time."(Interview with $\mathrm{Cl} 1,30 / 8 / 2012$ ).

The statement above shows that this respondent does not think it is inappropriate for women to participate in political activities at night, as is usual in West Sumatra. Further he asserted that:

“. . . Ooo dukungan politik . . sebagai pimpinan nagari tidak bisa disampaikan secara verbal dan terbuka. Karena wali nagari secara aturan formal tak boleh berpolitik, tak boleh mendukung salah satu calon, harus netral . . tetap dalam konteks yang netral . . tak boleh menjagokan seseorang. Sebetulnya kita tetap berkeinginan, calon yang berasal dari wilayah nagari kita bisa terpillih, jadi caranya yaaa tetap mendukung mereka dan tidak menganggu kegiatan kampanye dan tujuan mereka, artinya mereka kan punya hak untuk memasang baliho. . . baliho mereka itu harus dijaga dan diamankan."

“. . . My political support, as the head of the nagari, can't be verbal and open. There are regulations that state the head of a nagari may not be involved in politics, may not support one candidate; they 
have to be neutral and maintain a neutral context without supporting any one person. Of course, I still hope that a candidate from my area will win, so I have to support them without interfering in their campaign. They have the right to put up their banners and I make sure their banners stay undamaged and in place." (Interview with $\mathrm{Cl} 1,30 / 8 / 2012)$.

Community leader 2 supports women in politics because he feels that Minangkabau women should serve as role models and their position in the extended family will lead them to become community leaders, including in politics. Respondent 3 felt that neutrality and objectivity were important in supporting women in politics. Any support given to them should be based on their capacities and capabilities. Respondent 5 had a similar opinion and noted that it was not wrong for women to be involved in politics, and, as a community leader, she supported them. However, these candidates should not be supported because they are women; they should be supported because of how they approach the community and how familiar they are with the needs of the public.

The views of community leader 4 were somewhat different. As the head of a clan, he tended to use traditional rhetoric in discussing this issue. He mostly referred to traditional Minangkabau culture and sometimes mentioned recent events in contemporary Minangkabau society. For example, in discussing women politicians, he stated that this issue should not be seen in only one dimension. He explained in Minang:

“. . Iyo . . . ambo ndak tungga bapaham adek do e . . ndak tungga ko maksudnyo ... kalau nyo mampu di bidangnyo ndak masalah.”

“. . I I do not have just one way of looking at this in the context of tradition. This means that, if a woman is capable in her area of expertise, there is no problem." (Interview with CL 4, 15/10/2012).

Further, he continued that the natural role of Minangkabau women is to act as mediators within their extended family. He said in Minang: 
“... O jadi subannayo Bundo Kanduang tu ... mediator . . a a itu baju nan ba siba tu . . . penghubung dua kubu . . kan penyambung dua kubu ko haa.. . nyo harus menjadi mediator dima sajo barado."

"... Well, the nature of a Bundo Kanduang is to be a mediator ... We say this is like a garment with two sides. She has to mediate between two factions, connect these two factions. She has to be a mediator wherever she goes." (Interview with CL 4, 15/10/2012).

\section{The Voters}

In this section, the perceptions of voters about female politicians in West Sumatra will be discussed. Twenty two voters living in five different cities and regencies in West Sumatra were surveyed using different means. The cities and regencies where these voters live are the locations where female politicians have been elected to local parliaments. Five voters from the areas represented by each of these parliaments were selected. Each of them was interviewed in depth while the other voters were asked to complete a questionnaire. Of the 20 questionnaires expected, only 17 were returned. These were received from 11 female voters and six male voters. Of the five voters who were interviewed, 2 were male and 3 were female.

The sections below describe the five voters who were interviewed in-depth and outline their opinions. They were asked questions ranging from whether the involvement of women in politics is important, whether the matrilineal system benefitted women who are in politics, their considerations in choosing a candidate to vote for, their opinion on the performance of female MPs, whether politics is an appropriate field for women and whether male or female politicians are more trustworthy. The second part below will describe the results obtained from the 17 questionnaires completed by voters in areas where female MPs have been elected. 


\subsection{Interviews with Voters}

The five voters interviewed in depth are of Minangkabau ethnic background. They have a range of education, age and occupation. These are described below in numerical order.

Voter 1 is a member of a local parliament in a regency of West Sumatra for the period 2009-2014. He belongs to the United Development Party (PPP) and has been active in the party since the Reform Era. Before entering politics, he was a businessman and fishery entrepreneur. His educational background consists of a bachelor's degree. At the time of interview, he was 52 years old.

Voter 2 is a retired lecturer from a public university in West Sumatra. She has been active in the Golkar Party since the Soeharto era and followed the campaigns in the 1997 and 1999 elections. She noted, however, she did not take on a major role in the party because her main occupation was as a university lecturer. During the Reform Era she has been involved in politics because her extended family joined the National Mandate Party (PAN). Her husband, who is also a lecturer, gave her the freedom to be involved and active in social and political organisations. She was 72 at the time of interview.

Voter 3 is a housewife with three children. She became a community activist in her area in 1987. More recently, she became the head of the Muslim Women's Organisation (Badan Kontak Majelis Taklim-BKMT) in Air Tawar, Padang. Her husband, who retired from a private company in Padang, allowed her to take part in social organisations. Voter 3 is a high school graduate who was 60 years old at the time of interview.

Voter 4 is a single parent. She supports her three children by selling groceries in the market on a small scale. She was a high school graduate aged 44 at the time of interview. She is a constituent of one of the male MPs in her area.

Voter 5 is in the engineering business. He holds a bachelor's degree and was 40 years old at the time of interview. His business has brought him into contact with 
people from different ethnic backgrounds around Indonesia. This experience has convinced him that his own ethnic background as a Minangkabau is unique.

\subsubsection{The Importance of Women in Politics}

All five voters felt that the involvement of women in politics in Minangkabau is important. One reason they put forward for this is that many voters are women and so it might serve their interests if more women were in office. Other reasons included to raise the value of women and to empower them.

Voter 1 said that it was important for women to serve in office because the community is dominated by women. As so many women vote, it would be better if their interests were expressed by women. As he said in Minangkabau:

“. . . Iyo . . . anggota nan laki-laki labiah banyak, tapi nan jadi warga labiah banyak padusi kan ... Jadi labiah mudah dek mereka kok ka batanyo, bakonsultasi bagai, kan bisa labih mudah, ndak malu-malu bagai manyampaikan makasuik jo kandaknyo kalau bacarito ka sasamo padusi."

“. . . There are more male members but there are more females in the population. So it would be easier for them if they wanted to ask or consult with [their representative]. They wouldn't have to be embarrassed to present their concerns or make their demands if they were dealing with other women." (Interview with Voter 1, $31 / 8 / 2012$ ).

Similar ideas about the importance of women in politics came from voters 2,3 and 5. These three voters mentioned that women in Minangkabau have a unique position in the culture such that it is classified as matrilineal. Voter 2 said that women in Minangkabau are precious and valued since there is a traditional position for them and they have power in the extended family. Voter 3 agreed that women in politics are important because women can empower other women if they become decision makers, such as a member of parliament. Voter 5 said that it is common to see women in politics in West Sumatra or from a Minangkabau background. 
Another reason was suggested by voter 4 why it would be better if there were more women in office and in parliament. This was because most women rely more on their feelings when making decisions while men mostly rely more on logic. As she said in Minangkabau:

“. . Yo laki-laki se sadonyo ba a namonyo tu . . . Kantua tu kan istilahnyo lah hampia samo lo bantuak rumah tangga nak, ado iko, ado itu . . . banyak bagian-bagiannyo. Tu kalo lah ado lo padusi untuak maurusnyo kan ... rancak tu . . . Kan jiwa padusi Jo laki laki babeda. Yo misalnyo dalam bidang pendidikan menuruik nyo ko iko ... iko ... kalau laki laki lain lo. Kan kebanyakan padusi mamakai perasaan kan, haa jadi adolah rasonyo ... tapi kalau lakilaki kan ba aaaa gitu, kalo A nyo aa se kan tanpa pertimbangan.s Bukan sadonyo tapi pada umumnyo."

"... If there are only men, what do you call it, an office is almost like a household. There's this and there's that, there a lot of sections. If there are some women to deal with all this, that's good. Women and men are different, you know. For example, in education, according to women, it's like this and this and this. For men, it's different. Most women use their feelings so there's emotion. But men, you know, it's all without any sentiment, not all of them, but generally, they're like this." (Interview with Voter 4, 21/9/2012).

\subsubsection{The Matrilineal System and Its Benefit for Women in Politics}

Of the five voters, Voter 1 said that there is no connection between the matrilineal system in Minangkabau and women in politics. Voter 4 said that she was not sure about this and did not have any feelings about the benefits and connections between the matrilineal system and women's involvement in politics. Three voters $(2,3$, and 5$)$ said there was a benefit of the matrilineal system that can be used by women who are involved in politics in West Sumatra.

Voter 1 said there is no correlation between the matrilineal system and women in politics. His reason is that the role of women in Minangkabau is to take care of their children and family. As he stated in Minang:

“... Mmm ndak manuruik ambo (ndak ado hubungan) ... fitrahnyo padusi tu kan cendrung maurus keluarganyo dulu . . . tapi bak kecek 
ambo tadi . . . mujua juo ado padusi di dewan . . kok ado padusi duduk di dewan kini kan iyo bisa mungkin mampajuangkan pihak kaum ibu . . kan baitu?"

". . . In my view, there is no connection. The place of women is to care for their family first. But like I said earlier, we're lucky if there is a woman in parliament. If there are women in office now, maybe they can fight for the interests of other women, can't they?' (Interview with Voter 1, 31/8/2012).

When questioned more deeply, it seemed that this voter believed in the importance of women in parliament, but did not see a connection between the matrilineal system and their participation. He went on to say that the most important thing is for women to take care of their children. As he said in Minang:

"Yooo subananyo kewajiban perempuan nan utamo mendidik anak ... aa anak tu kan amanah bagi ibu Bapak kan . . Kalau mengejar karir di Dewan misalnyo kok lai ndak ka manganggu kewajiban mendidik anak dan kewajiban sebagai ibu rumah tangga mako ndak ba mereka di politik. Sedangkan kalau ibu jadi sibuk dan anak yang seharusnya dibina oleh ibu bapak diabaikan pulo, dek talampau sibuk di dewan. Iko ndak batua tibonyo. Jadi kok lai ndak ka manganggu kewajiban mengurus anak dan kewajiban sebagai ibu rumah tanggo ndak ba a dan ancak padusi duduak di dewan."

"Yes, the main responsibility of women is to raise their children. Children dictate the roles of their mother and father. If the mother is pursuing a career in parliament, for example, and that doesn't interfere with her responsibility to raise her children and her responsibility as a housewife, it's fine for her to enter politics. But if the mother is busy and the children who should be being raised by the mother and father are ignored, because the mother is so busy in parliament that is wrong. So if it isn't going to interfere with her responsibilities in raising her children and taking care of the household, it is fine and good for women hold political office." (Interview with Voter 1, 31/8/2012).

Voter 4 admitted that she did not have any idea about whether women in politics benefitted from their matrilineal culture. She seemed to feel there is no relation 
between the two because the assets that might be used by women in politics are not private assets and belong to the extended family.

Voters 2, 3, and 5 have a similar opinion that women in a matrilineal society benefit from the culture if they enter politics. Their reasons include that women are already active in their extended family and have an important position. When they wish to expand their sphere of influence to the public arena, people already respect and value them. A similar idea was expressed by Voter 3. Voter 5 stated that people of Minangkabau background are familiar with the democratic system, having seen it in operation in their extended family. From childhood, people are used to seeing members of their extended family trying to achieve consensus and agreement. As he said in Minang:

"Mmm menurut ambo, awak maliek budaya minang ko dulu, budaya Minang ko . . . istilahnyo . . . dibanding berbagai suku di Indonesia, kan suku Minang ko yang paling demokratis kan . . jadi kebiasaan demokratis nyo itu lah ado di dalam dirinya. Jadi kalaupun perempuan itu terjun ke politik . . . iyo lah biaso se dek padusi karano sudah terbiasa di lingkungan demokratis. . .jadi biaso sajo perempuan ko terjun ke dunia politik."

"In my opinion, Minangkabau culture, if you compare it with other ethnic groups in Indonesia, has always been the most democratic. The custom of democracy is within us, so when women enter politics, it is usual for them because they are accustomed to a democratic environment. So it is natural for women to enter politics." (Interview with Voter 5, 20/10/2012).

\subsubsection{Considerations in Choosing Candidates}

When asked about their considerations in choosing a candidate, of the five voters, three (Voters 1, 3, and 4) would choose a male candidate while Voter 2 said that she tends to go with her feelings. Voter 5 stated that he bases his decision on a candidate's capacities and capabilities. Their reasoning is described in more detail below. 
Voter 1 explained that during the 2009 election his party did not put any female candidates in its first three rankings of candidates and he wanted to select the most likely candidate to be elected and who would benefit the party. Voter 3 said that, in the 2009 election, she chose a male candidate because she went along with her husband who chose that candidate. Voter 4 said that she voted for a male candidate because she is a constituent of this candidate and he paid attention to her family during the campaign process. As she said in Minang:

"Aaaa. . . O awak katiko itu memilih (menyebut nama salah seorang anggota dewan: Mes. Alasannyo... Yooo awak berharap, bisa memperjuangkan kebutuhan awak. . . Aspirasi awak bisa disampaikan ka beliau ... yo tersalurkan lah."

"Oh yes, I voted for him. The reason was that I hoped he would pay attention to our needs, we could tell him our aspirations . . . there would be a way of being heard." (Interview with Voter 4 21/9/2012).

When further asked why she did not choose a female candidate, this voter said that she knew the male candidate and felt closer to him and that a better choice would be a person she already knew. As she stated in Minang:

“. . . Hmmm ba a yo, waktu itu yang awak tahu dan acok basuo jo wak apak ko ... acok datang ka kadai tampeka wak manggaleh... yo awak lebih kenal jo beliau. .. ancak lah yang awak kenal lai nan awak piliah."

"... Well, at the time, I knew him and often saw him when he came into my shop. I knew him so I thought it would be best to vote for someone I knew. So I voted for him." (Interview with Voter 4, 21/9/2012).

Another reason came from Voter 5 . He voted based on the record of the candidates. He felt it would not be wrong to vote for a female candidate as long as she had good capacities and capabilities. He stated in Minang:

“. . Y Yang jadi pertimbangan tentu track record si Caleg tu, ba a salamo ko bisa dipicayo ... jujur ndak ... dari track record ko kan bisa awak caliak kan ... jadi yo berdasarkan apolah tibonyo ... . kemampuannya ... kalau ternyata padusi ko lebih berbobot, lebih hebat, lebih bsia dipicayo yo padusi kolah yang dipiliah." 
“. . . What I considered, of course, was the track record of the candidates. Whether they had been trustworthy, honest or not. From their track record, you can tell. So I based my vote on that, their abilities. If it had turned out the woman was more substantial, better, more trustworthy, I would have voted for the woman." (Interview with Voter 5, 20/10/2012).

When asked about how it was possible to tell whether a candidate deserved to be elected and how their track record could be found out, this voter explained that the candidate would have to make sure the public knew him. He states in Minang:

"Yo kan dari apo salamo ko, biasonyo urang yang serius terjun ke politik ko kan ndak bisa tibo-tibo se. Urang ndak tahu do . . . jadi dari awal lah nyo bina, lah nyo bantuak kan, nyo perkenalkan dirinyo, ikuik kegiatan-kegiatan social jadi urang banyak bisa tahu kan. Kalau yang paling capek subananyo dari kejadian yang pernah dicaliak. Misalnyo jadi bupati, yang paling acok a nyo maagiah pengajian ka musajik-musajik kan. Aaa capek urang kenal nyo, yang mode itu punya kesempatan bisa manang."

"Well, from what they've done in the past. Usually, a person who is serious about a political career will not appear suddenly. People won't know them. So from the beginning, they have to develop a relationship, introduce themselves around, go to social events so a lot of people get to know them. The fastest way from what I've seen, for example, was a regent who often preached in the mosques. People got to know him quickly. That strategy gave him the chance to win." (Interview with Voter 5, 20/10/2012).

\subsubsection{Opinions about the Performance of Female MPs}

When asked their opinion about the performance of female MPs, the voters interviewed had several views, ranging from seeing them as active in parliament, not knowing much about their performance, to not seeing them as having much effect.

Voter 1 said that, based on his experiences as a colleague of female MPs, even though there are fewer of them, female MPs are quite active in parliament. He explained in Minang: 
"Yooo katiko rapek-rapek. . . rapek komisi, rapek jo eksekutifbagai, mereka lai mengecek . . . mambuek laporan, kadang mereka jadi juru bicara ... kan bagiliran tu untuak panyampaian pandangan umum."

"When there are meetings, committees, meetings with the executive, and so forth, they speak up, they give reports, and sometimes they act as a spokesperson. We take turns reporting on the views of the public." (Interview with Voter 1, 31/8/2012).

Two voters (2 and 4) had a somewhat different view. They admitted they did not follow the performance of female MPs in their local parliament as they were not constituents of these politicians. They did not seem to be very interested in politics. Voter 3 also paid little attention to the activities of female MPs but she acknowledged that as long as female MPs were skilled and competent to do their job, she would accept women in this role.

Voter 5 noted that he did not exactly know what the female politicians in his local parliament had done because he rarely sees this covered in the print media or on television. He explained in Minang:

“. . . Ambo ndak melihat banyak kiprahnyo di masyarakat do . . . ntah sia-sia nan jadi anggota dewan ko . . yang ado masuk TV iyo lai tahu, itu di DPR pusat, Angelina Sondakh . . aa lai kenal. Tapi kenal itu kan umumnyo karena dek berkasus korupsi, ndak kelihatan kegiatannya."

“...I haven't seen much about their activities in the community. Maybe they're wasting their term in parliament. The ones who are reported about on TV, I do know. Like in the national parliament, I know Angelina Sondakh. But generally I know them because they are involved in corruption cases. What they've actually done as a legislator is not discussed." (Interview with Voter 5, 10/20/2012).

\subsubsection{Politics as an Appropriate Field for Women}

The voters interviewed had a range of opinions on whether or not it was appropriate for women to be involved in politics. Voter 1 stated that, as long as 
women did not ignore their family and did not disregard their domestic duties, it was fine for them to enter politics. By contrast, Voter 2 said that she and her extended family often saw women with a higher education. She noted that since her childhood in the colonial era, both boys and girls were sent to high school. According to her, because women already had high levels of education, it is usual to see women become politicians, which was appropriate. She explained in Minang:

“. . . Ndak . . ndak ado di ambo pikiran mode itu. Manga sekolah tinggi ... manga ka DPRD. Ambo ndak, kebetulan keluarga kami . . . haa ko keluarga kami pendidikannya cukup lah. . minimal dulu sekolah di normal school inlander .. . haa itu mama ambo. . . cukup tinggi zaman itu ... jadi alhamdulilah semua keluarga kami harus sekolah tinggi, sekolah semua."

“.... I never questioned that, why girls had to go to school, or why women should enter politics. I didn't, our family happened to, our family was well educated. Everyone at least attended the Inlander Normal School [high school run by the Dutch colonial government for Indonesians]. My mother did that which was a lot for that era, so, God willing, everyone in our family had to finish school. Everyone had to go to school." (Interview with Voter 2, 9/9/2012).

Further, she continued that it is normal for women to become politicians, but the important thing is that women should not be involved in the negative side of politics. Instead, they should be selective and choose what is best for them. As she said in Minang:

“. . . Ambo kan berpolitik lo. Meski itu dulu, menurut ambo ndak salah. Apagi kita perempuan sudah banyak berpendidikan tinggi, kan kita bisa memilah-milah . . . kan ndak semua nya di politik itu kita tiru ... mana yang baik ... dan menguntungkan bagi kelompok kita ... itu kita ambil."

"... I used to be involved in politics, although that was some time ago. In my opinion, it isn't wrong, especially for us women who are educated. We can choose. Not every aspect of politics should be imitated. The things that are good and beneficial for our group, those are the ones we should choose." (Interview with Voter 2, 9/9/2012). 
Voters 3 and 4 were of the opinion that politics is more appropriate for men. Their reasons were somewhat different however. Voter 3 thought that politics was difficult for women. As she said in Minang:

“. . . Hmm Haa . . . haa raso-rasonyo iyo banyak nan laki-laki daripado padusi di politik itu . . . rasonyo memang barek dek padusi, tapi caliak juo kemampuan urang tu."

"Hmmm. . . It seems like there are more men than women in politics. I think it is hard for women, but you have to look at the person's abilities too. .." (Interview with Voter 3, 9/9/2012).

This voter seemed uncertain in her views. When asked whether it is more appropriate for men or women to enter politics, she said that politics is more appropriate for men. As she said in Minang:

“. . Iyooo, rasonyo memang karajo laki-laki kalau politik itu kan

“. . Well yes, I think politics is more of a men's job..." (Interview with Voter 3, 9/9/2012)

Similar to Voter 3, Voter 4 thought that it is all right for women to enter politics if they have the ability to do so but noted that she has observed more men than women in politics. As she explained in Minang:

“. . . Yoo, a namonyo tu . . bapolitik tu buliah se . . tapi kan banyak lo karajo padusi ko nak . . maurus anak . . suami . . . keluarga jo rumahtanggo bagai... Yoo zaman kini ko, awak kan maalami karajo di rumah iyo, di kadai awak iyolo . . . ndak ba a padusi di politik... tapi mungkin barek nak, dek dirumah iyo pulo."

“. . . Well, you know, it's OK for women to go into politics, but women already have a lot of other work. They have to deal with their children, their husband, and their home and so forth. In these times, for instance, I do the housework, I work in the shop. It's fine for women to go into politics, but it might be hard as they have to work at home, too." (Interview with Voter 4, 21/9/2012). 
Voter 5 had the opinion that it is appropriate for women to enter politics. His opinion is based on the idea that Minangkabau is a democratic culture and supports equality in the community.

\subsubsection{Trustworthiness of Male and Female Politicians}

When asked about the trustworthiness of male and female politicians, the voters interviewed gave a number of responses. Some felt that trustworthiness was not related to gender while others felt the burden of political office was great and better carried by men.

Voter 2 noted that women must support female MPs, but only those with the required skills, abilities and capabilities, especially in relation to managing their time and having the discipline to carry out their domestic and public tasks. Voter 1 and Voter 3 had a similar opinion. They suggested that female MPs have many tasks, in their own household and in parliament and thus it might be hard for them to manage all these duties. For this reason, they felt it would be better to trust male MPs to carry out the responsibilities of their office. Voter 4 stated that she trusted male MPs because she was the constituent of one. Voter 5 mentioned that men or women can be trustworthy or not, but the important thing is their achievement and efforts that can be seen by the community and their constituents and also their track record. As he said in Minang:

“. . . O kalau masalah bisa atau ndak dipicayo itu samo se laki-laki jo padusi . . . itu kan sifat manusia. . .samo se laki-laki jo padusi . . .samo-samo bisa dipicayo . . . samo-samo ndak bisa dipicayo . . . caliak se lah yang ditangkok KPK . . . ado yang padusi ado yang laki-laki . . . ndak bisa memastikan kalau padusi lebih jujur atau laki-laki lebih jujur, ndak bias . . . Jadi yo itu tergantung track recordnya ... harus dicaliak ... sebelumnya ba a track record nyo ... kalau alun tahu awak bantuak urangnyo, alun tahu awak sifat dan hasil karajo nyo salamoko maa bisa awak picayo urang tu."

"... When it comes to whether they can be trusted, men and women are just the same. It's part of character. Men and women are the same. They can be equally trustworthy or equally untrustworthy. Just look at who has been arrested for corruption. Some are women, some are men. There is no way to tell whether women are more 
trustworthy or whether men are. So it all depends on their track record. You have to look at that before anything else, how is their track record? If you don't know what kind of a person someone is, if you don't know their characteristics and what their work is like, how can you trust that person?" (Interview with Voter 5, 20/10/2012).

\subsection{Voter Questionnaires}

Of the seventeen voters who responded to the questionnaire, eleven were women and six were men. Their responses are summarized below and produced results similar to the interviews discussed above.

\subsubsection{Female voters}

Question 1 concerned the correlation between women, politics and Minangkabau culture. The question consisted of five sub questions which respondents were asked to agree or disagree with. Their answers are contained in Table 4.

Table 4. Female Voters' Opinion on Women, Politics and Minangkabau

\begin{tabular}{|c|c|c|c|c|c|}
\hline No & Questions & Agree & Disagree & $\begin{array}{l}\text { Don't } \\
\text { Know }\end{array}$ & Other \\
\hline 1 & $\begin{array}{l}\text { Having female MPs in } \\
\text { West Sumatra is } \\
\text { important }\end{array}$ & 5 & 4 & 1 & $\begin{array}{l}1 \\
\text { depends } \\
\text { on } \\
\text { situation }\end{array}$ \\
\hline 2 & $\begin{array}{l}\text { The success and failure } \\
\text { of female MPs because } \\
\text { of their gender }\end{array}$ & 4 & 7 & & \\
\hline 3 & $\begin{array}{l}\text { Communal property in } \\
\text { West Sumatra can be } \\
\text { used to support a } \\
\text { political career }\end{array}$ & 1 & 10 & & \\
\hline 4 & $\begin{array}{l}\text { Prominent } \\
\text { Minangkabau women } \\
\text { from the past affect the } \\
\text { experience of women in } \\
\text { politics }\end{array}$ & 7 & 3 & 1 & \\
\hline
\end{tabular}

Source: interview with voters, tabulation by author 
From the above table, it can be seen that five female voters thought it was important for there to be female MPs, four disagreed, and one did not know. One female voter stated that it depended on the situation. The reasons given by the five female voters who believed it was impiortant for there to be women in politics in West Sumatra were; 1) Equality - if men can be in parliament, women should be able to be as well. 2) Women in parliament have a specific psychological role. 3) By having women in parliament, women's aspirations will be fulfilled. 4) Women in parliament will represent women's issues and women's interests. 5) One voter did not give a reason.

The female voters who disagreed had several reasons, including: 1) Most women are weaker than men, thus politics is not really good for women who may not be able to overcome problems the way men can. 2) It would be more appropriate and better for women to be educators than politicians. 3) It is common to see men as leaders. 4) Minangkabau women have significant influence and power in society without being in parliament, thus women have no need to serve in parliament.

One female voter who thought it depended on the situation, felt that a woman could be a leader if there was no available male. In other words, women would be acceptable MPs if, in a given area, there were no male candidates to represent people's interests. By contrast, if there were many male candidates, it was not important to have women in parliament.

Sub-question 2 about women's success relating to their gender had four voters agree and seven disagree. Their reasons for agreeing included: 1) the ability of women in politics is less than men. 2) Voters have a tendency to vote for men; even women are likely to vote for male politicians. The voters' reasons for disagreeing included: 1) Success or failure is not related to the candidates' gender. 2) When women are in positions of power, they do not seem that good, as in the case of Megawati (one of Indonesia's past presidents and daughter of the nation's first president, Sukarno). 3) Success or failure depends on their capacities. 4) Success or failure is determined by their capabilities in their communities. 5) 
There is no reason that explains success or failure. 6) Success or failure relates to the trust of voters in their MP and the capacity of the MP, male or female. 7) Success or failure depends on the individual's knowledge and capacities.

Sub-question 3 relating to the use of communal property to support political activities resulted in one voter agreeing and 10 voters disagreeing. The reason the one individual gave for agreeing was that communal property can be used for special reasons such as charity and social commitments to people in the community, including for political ends, especially when there is no-one traditionally entitled to use the property (such as when the family has died out). Ten voters who did not agree with using communal property to support a political career had the following reasons: 1) Communal property is owned by a clan, not by one individual. 2) Women seldom use communal property to support a political career and it is not appropriate for female politicians to use communal property for their own interests. 3) There are rules about the use of communal property; the four acceptable reasons are the cost of rehabilitating of communal house, the cost of a wedding ceremony for female members of the extended family, the cost of a funeral for members of the extended family and the cost of installing a new traditional leader of the extended family. 4) It is not good to use communal property to gain political office. A person's leadership qualities will be questioned when she does not use her private assets.

Sub-question 4, about whether prominent Minangkabau women in the past affected the experience of women in politics was agreed with by seven voters and disagreed with by three voters. One voter did not know.

Question 2 had six variables describing the considerations of voters in choosing a candidate. Voter responses are contained in the table below: 
Table 5: Female Voters' Considerations in Choosing a Candidate

\begin{tabular}{llccc}
\hline \hline No & $\begin{array}{l}\text { Element of } \\
\text { considerations }\end{array}$ & Agree & Disagree & $\begin{array}{c}\text { Don't } \\
\text { Know }\end{array}$ \\
\hline 1 & Popular in community & 2 & & \\
2 & $\begin{array}{l}\text { Because the candidate is } \\
\text { a woman }\end{array}$ & 1 & & \\
3 & Personal abilities & 4 & \\
4 & Long experience in the & 1 & \\
& political arena & 1 & \\
5 & All of the above & 1 & \\
6 & Other (family relative) & & & \\
7 & & & \\
\hline
\end{tabular}

Source: interview with voters, tabulation by author

From table 5 above it can be seen that of 11 voters, four voters tended to choose a candidate based on the capabilities of the candidate, while two voters choose based on name recognition of the candidate. One voter chooses based on each of the other considerations.

Question 3 describing voters' views on the performance of female MPs in parliament, seven elements were used as indicators. These are contained in the table below.

Table 6: Female Voters' Opinion about the Performance of MPs in Parliament

\begin{tabular}{llcccc}
\hline \hline No & Action and attitudes & $\begin{array}{c}\text { Female } \\
\text { MPs }\end{array}$ & $\begin{array}{c}\text { Male } \\
\text { MPs }\end{array}$ & $\begin{array}{c}\text { Male \& } \\
\text { Female MPs }\end{array}$ & $\begin{array}{c}\text { Don't } \\
\text { Know }\end{array}$ \\
\hline 1 & $\begin{array}{l}\text { Willing to express opinion in } \\
\text { meeting }\end{array}$ & 1 & 9 & \\
2 & $\begin{array}{l}\text { Credible, responsible and } \\
\text { honest }\end{array}$ & 4 & 1 & 6 & 1 \\
3 & Disciplined & 4 & - & 3 & 3 \\
$4 \quad \begin{array}{l}\text { Frequently meets with the } \\
\text { community, voices the } \\
\text { aspirations of the community } \\
\text { and pays attention to } \\
\text { constituents and supporters }\end{array}$ & 2 & 4 & 2 & 2 \\
5 & $\begin{array}{l}\text { Has many long- standing } \\
\text { constituents }\end{array}$ & 1 & 5 & 3 & 2
\end{tabular}



in campaign

Source: interview with voters, tabulation by author

A wide range of opinions regarding the performance of male and female MPs can be seen in the table 6 above. Of 11 voters, nine voters had the opinion that male and female MPs are willing to express their opinion in meetings, and one voter each preferred male MPs and female MPs. Similarities between male and female MPs in terms of credibility, responsibility and honesty were reported by six voters, while four voters said female MPs tended to be better in terms of these characteristics and one said males would be better.

In terms of their diligence in doing their job, one voter did not know, four voters said that female MPs tended to be more diligent while three said that male and female MPs are equally diligent. Of 11 voters, six said that female MPs are more disciplined than male MPs, while only two voters felt that male MPs were disciplined and three voters said that male and female MPs are the same in terms of discipline.

For the item 'frequently meets with the community, voices the aspirations of the community and pays attention to constituents or supporters', four voters denoted that male MPs do so frequently, while two voters consider that female MPs are better on this measure and two voters feel that male and female MPs are the same. Three voters said they did not know. Of 11 voters, five voters said that male MPs have many long standing constituents, while by contrast only one voter thinks that female MPs do, while three voters think male and female MPs are equal in this. Two voters did not know. In terms of being more courageous in making frequent and novel innovations in campaigning, five voters said this is more likely to be done by male MPs, four voters said both male and female MPs do so and one voter felt female MPs were more likely to do so while one did not know.

Question 4 asked about appropriate occupations for men and women. Various kinds of occupation were presented as examples. Respondents' answers are contained in Table 7. 
Table 7: Appropriate Occupations for Men and Women According to Female Voters

\begin{tabular}{llccc}
\hline \hline No & Occupation & Female & Male & $\begin{array}{c}\text { Male and } \\
\text { Female }\end{array}$ \\
\hline 1 & Secretary & 9 & - & 2 \\
2 & Teacher/educator & 7 & - & 4 \\
3 & Civil servant & 4 & 3 & 4 \\
4 & Politician & 2 & 5 & 4 \\
5 & Trader & 3 & 1 & 7 \\
6 & Tailor/dressmaker & 3 & 2 & 6 \\
7 & Chef & 2 & 1 & 8 \\
8 & Laborer & - & 7 & 4 \\
9 & Professional (lawyer, & - & 4 & 7 \\
& journalist, doctor, etc) & & & \\
\hline \hline
\end{tabular}

Source: interview with voters, tabulation by author

Table 7 shows that, of 11 voters, nine felt the job of secretary was a more appropriate occupation for women. Of 11 voters, two voters said that the job of politician is an appropriate occupation for women. Five voters had the opinion that men were more appropriate as politicians and four voters said both men and women could be politicians.

Question 5 asked about the advantages to Minangkabau women in politics that derived from their matrilineal culture. Respondents' answers are contained in Table 8.

Table 8: The Advantages to Minangkabau Women in Politics According to Female Voters

\begin{tabular}{lllll}
\hline \hline No $\quad \begin{array}{l}\text { Social/cultural aspects of } \\
\text { Minangkabau society }\end{array}$ & Agree & Disagree & Don't know \\
\hline $1 \quad \begin{array}{l}\text { Having extended family that can } \\
\text { supply supporters, constituents and } \\
\text { voters during candidacy }\end{array}$ & 9 & 2 & \\
2 & $\begin{array}{l}\text { Having communal property that can } \\
\text { be used and borrowed against as a } \\
\text { means of covering political costs }\end{array}$ & 1 & 10 & \\
3 Having high social status as the \\
daughter of a noble family; including
\end{tabular}




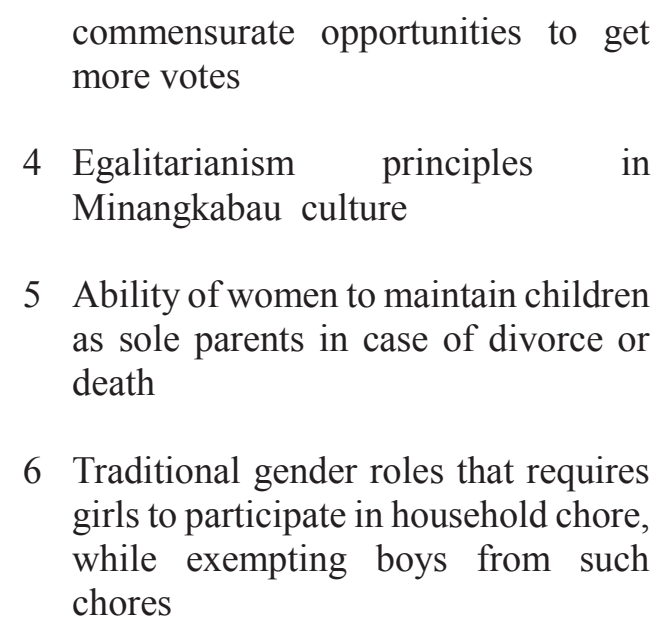

5 Ability of women to maintain children as sole parents in case of divorce or death

6 Traditional gender roles that requires girls to participate in household chore, while exempting boys from such chores

Source: interview with voters, tabulation by author

Table 8 shows that of 11 voters, nine agree that the extended family has a role during the candidacy of women, while two voters did not agree. In relation to the use of communal property, of 11 voters, 10 did not agree that such assets be used for political purposes. In relation to high social status or noble birth, of 11 voters, seven agreed, three voters disagreed, and one did not know.

In terms of egalitarianism, of 11 voters, seven agreed that this value was beneficial for female MPs, while one disagreed and one did not know. Regarding the ability of women to financially support children, of 11 voters, seven agreed that this phenomenon could affect women as candidates for parliament and four disagreed. For different treatment of Minangkabau boys and girls, three voters felt this was an advantage for women, seven disagreed, and one did not know.

\subsubsection{Male Voters}

Similar to the eleven women voters, the first question posed to the male voters was about the correlation between women, politics and Minangkabau culture. The question consisted of four sub-questions intended to solicit the opinion of voters about whether they agree with the question. The table below contains their answers. 
Table 9. Male Voters' Opinion on Women, Politics and Minangkabau

\begin{tabular}{|c|c|c|c|c|c|}
\hline No & Questions & Agree & Disagree & $\begin{array}{l}\text { Don't } \\
\text { Know }\end{array}$ & Other \\
\hline 1 & $\begin{array}{l}\text { Having female MPs in } \\
\text { West Sumatra is important }\end{array}$ & 4 & 2 & & \\
\hline 2 & $\begin{array}{l}\text { The success and failure of } \\
\text { female MPs because of } \\
\text { their gender }\end{array}$ & 1 & 3 & 2 & \\
\hline 3 & $\begin{array}{l}\text { Communal property in } \\
\text { West Sumatra can be used } \\
\text { to support a political career }\end{array}$ & 1 & 5 & & \\
\hline 4 & $\begin{array}{l}\text { Prominent Minangkabau } \\
\text { women from the past } \\
\text { affect the experience of } \\
\text { women in politics today }\end{array}$ & 3 & 3 & & \\
\hline
\end{tabular}

Source: interview with voters, tabulation by author

Table 9 shows that of six male voters, four voters agree and two voters disagree on sub-question 1, the importance of female MPs. Voters who disagreed gave as a reason that they did not see a real contribution of female MPs, thus the existence of female MPs was not important. Four voters who agreed, had various reasons that included: 1) in a matrilineal society women have opportunities in the public sphere, including in politics. 2) That women mostly focus on their feelings and this is advantageous when they become MPs. 3) They have a legal right and there are regulations to accommodate women in politics. 4) Having women in parliament shows that there is no discrimination against women in politics and shows that women in West Sumatra are smart.

Sub-question 2 relating to the success or failure of women in politics as a function of their gender was responded to differently, with one voter agreeing and three disagreeing, while two voters did not know. The reasons for agreeing were that local parliaments need women as MPs because women are more aware of their emotions and are more likely to use their feelings in addressing community issues. By contrast, voters who disagreed indicated that the success of MPs is based on their actions, achievements, and contributions to their community. This 
potential was viewed as similar for male and female politicians and not related to gender.

Sub-question 3 relating to the use of communal property by female candidates was agreed with by one voter. The reason given was that it is very expensive to run for political office. If every member of their extended family supports the candidate and agrees that communal property be used, there was no problem in this voter's view, By contrast five voters did not agree. Their reasons ranged from the fact that communal property is owned jointly by everyone in the extended family, that it is not only to be used by women, and communal property should not be used for politics because, in terms of traditional law and custom in Minangkabau, there are rules about using communal property.

Sub-question 4, regarding whether prominent Minangkabau women in the past affected women in politics, was agreed with by three voters and disagreed with by three.

Question 2 described considerations in choosing candidates. This question had six variables describing the considerations of voters in choosing a candidate. Voter responses are contained in the table below:

Table 10: Male Voters' Considerations in Choosing a Candidate

\begin{tabular}{lllll}
\hline \hline No & Element of considerations & Agree & Disagree & $\begin{array}{c}\text { Don't' } \\
\text { Know }\end{array}$ \\
\hline 1 & Popular in community & 1 & \\
2 & The candidate is a woman & & \\
3 & Personal abilities & 4 & \\
4 & Long experience in the political arena & 1 & \\
5 & All of the above & & \\
6 & Other (family, relative) & \\
\hline \hline
\end{tabular}


Table 10 above shows that, of six voters, four agreed that their choice of candidate is based on personal abilities, while one chose popularity while another chose experience. By contrast, other variables, including because the candidate is a woman and a combination of all variables (all of the above), were not considerations for these voters.

Question 3 asked about respondents' opinion of the performance of MPs in parliament. In describing voters' views on the performance of female MPs in parliament, seven elements were used as indicators. These are contained in the table below.

Table 11: Male Voters' Opinion about the Performance of MPs in Parliament

\begin{tabular}{lllll}
\hline \hline No & Action and attitudes & $\begin{array}{l}\text { Female } \\
\text { MPs }\end{array}$ & $\begin{array}{l}\text { Male } \\
\text { MPs }\end{array}$ & $\begin{array}{l}\text { Male \& } \\
\text { Female } \\
\text { MPs }\end{array}$ \\
\hline 1 & $\begin{array}{l}\text { Willing to express opinion in } \\
\text { meeting }\end{array}$ & - & 3 & 3 \\
2 & $\begin{array}{l}\text { Credible, responsible and honest } \\
3\end{array}$ & 3 & - & 3 \\
4 & $\begin{array}{l}\text { Disciplined } \\
\text { Frequently meets with the } \\
\text { community, voices the aspirations } \\
\text { of the community and pays } \\
\text { attention to constituents and } \\
\text { supporters }\end{array}$ & 1 & - & 3 \\
\hline $\begin{array}{l}\text { Has many long-standing } \\
\text { constituents } \\
\text { More courage in making frequent } \\
\text { and novel innovations in } \\
\text { campaign }\end{array}$ & 1 & 5 & 2 \\
\hline \hline
\end{tabular}

Source: interviews with voters, tabulation by author

Of the six possible elements that might relate to the performance of female politicians, the first variable was chosen by three voters who felt that male and female MPs are equally willing to express opinions in meetings. Men and women were also seen as similar in terms of being credible, responsible and honest for which three voters chose female MPs and three both male and female MPs. Similar results were obtained for diligence. Of six voters, four voters said that 
female MPs are more diligent in performing their tasks while male MPs were chosen by two voters. Of the six voters, three said that male MPs meet more frequently with the community, voice the aspirations of the community and pay attention to constituents or supporters; one voter thought that women were better on this factor, while two voters said that men and women were equal. Five voters felt that male MPs have many long-standing constituents while one voter said that men and women were equal. Of six voters, five agreed that men have a lot of loyal constituents and are more courageous in making innovations in campaigning. Only one voter felt women do better on these issues.

Question 4 related to the occupations that are seen as appropriate for men and women in this society. Respondents' answers are contained in Table 12.

Table 12: Appropriate Occupations for Men and Women According to Male Voters

\begin{tabular}{llccc}
\hline \hline No & Occupation & Female & Male & $\begin{array}{l}\text { Male } \\
\text { and } \\
\text { Female }\end{array}$ \\
\hline 1 & Secretary & 5 & - & 1 \\
2 & Teacher/educator & 1 & - & 5 \\
3 & Civil servant & 3 & 1 & 2 \\
4 & Politician & - & 4 & 2 \\
5 & Trader & 2 & 4 & 1 \\
6 & Tailor/dressmaker & 2 & - & 4 \\
7 & Chef & - & 2 & 2 \\
8 & Labourer & - & 5 & 1 \\
9 & Professional (lawyer, & 1 & 5 \\
& journalist, doctor, etc) & & & \\
\hline \hline
\end{tabular}

Source: interview with voters, tabulation by author

Table 12 shows that, of six voters, five voters said that secretary was a more appropriate occupation for women, while none felt this was a male job and one said that either men or women might have this occupation. By contrast, of six voters, five said that being a teacher or educator was equally appropriate for men and women and one voter said this job was appropriate for women. Being a civil servant, according to three voters, was appropriate for women, while one voter said it was appropriate for men and two voters said this job was suitable for both 
men and women. For trader, of six voters, four said this job was more appropriate for men and one each thought this occupation was suitable for women or for both men and women. Of six voters, four voters said that tailor or dressmaker was a suitable occupation for both men and women and two voters said this job was for women. For work as a chef, two voters said the job was suitable for men, two for women, and two for either men or women. Of six voters, five said that a job as a labourer was appropriate for men and one thought both men and women could do this job. By contrast, professional occupations were seen as appropriate for both men and women by five voters while one voter said this job was better for men.

Question 5 had six variables describing the advantages to Minangkabau women in politics that derive from their matrilineal culture. The voters' opinions can be seen in the table below.

Table 13: The Advantages to Minangkabau Women in Politics According to Male Voters

\begin{tabular}{|c|c|c|c|c|}
\hline No & $\begin{array}{l}\text { Social/cultural Aspects of Minangkabau } \\
\text { Society }\end{array}$ & Agree & $\begin{array}{l}\text { Disa } \\
\text { gree }\end{array}$ & $\begin{array}{l}\text { Don't } \\
\text { know }\end{array}$ \\
\hline 1 & $\begin{array}{l}\text { Having extended family that can supply } \\
\text { supporters, constituents and voters during } \\
\text { candidacy }\end{array}$ & 5 & 1 & \\
\hline 2 & $\begin{array}{l}\text { Having communal property that can be } \\
\text { used and borrowed against as a means of } \\
\text { covering political costs }\end{array}$ & 1 & 5 & \\
\hline 3 & $\begin{array}{l}\text { Having high social status as the daughter } \\
\text { of a noble family; including commensurate } \\
\text { opportunities to get more votes }\end{array}$ & 4 & 2 & \\
\hline 4 & $\begin{array}{l}\text { Egalitarianism principles in Minangkabau } \\
\text { culture }\end{array}$ & 3 & 3 & \\
\hline 5 & $\begin{array}{l}\text { Ability of women to maintain children as } \\
\text { sole parents in case of divorce or death }\end{array}$ & 2 & 3 & 1 \\
\hline 6 & $\begin{array}{l}\text { Traditional gender roles that require girls to } \\
\text { participate in household chores, while } \\
\text { exempting boys from such chores }\end{array}$ & 2 & 3 & 1 \\
\hline
\end{tabular}

Source: interview with voters, tabulation by author 
As visible in the table above, of six voters, five agreed that the extended family can supply supporters, constituents and voters during candidacy, while only one voter disagreed with this. By contrast, five disagreed that communal property should be used for political reasons, while one agreed that this was acceptable. Of six voters, four agreed that high social status as the daughter of a noble family, including commensurate opportunities to get more votes, would be an advantage for female MPs, while two voters disagreed. Regarding whether egalitarianism in Minangkabau culture benefits female MPs, of six voters, three agreed and three disagreed.

When asked whether the ability of women to maintain children as a single parent in the case of divorce might affect female MPs, of six voters, two agreed, three disagreed and one did not know. For whether traditional gender roles that required girls to participate in domestic tasks while boys were free from this requirement might affect women in politics, two voters agreed, and three disagreed and one did not know.

The five voters interviewed had different educational backgrounds, occupations, experiences and ages. These differences resulted in the different opinions about MPs and also different attitudes of voters in discussing this topic. The voter who was a housewife, for example, seemed to be more uncertain about her answers to several of the questions. The male voters, especially those who had more experience outside of West Sumatra, seemed to be more confident in their opinions. Overall, these voters gave a range of answers to the questions that addressed the importance of women in politics, the matrilineal system and its benefits for women in politics, considerations in choosing candidates, opinions on the performance of female MPs, and the trustworthiness of male and female MPs. Similarities can be seen in terms of the importance of women in politics, with all voters indicating that it is important to have women as MPs even though their reasons were different. A number of opinions centred on the potential for women to add value to the office they hold and to supplement the ways of 
thinking and actions of the male politicians who outnumber them and who have historically dominated the institution.

In considering the benefits of the matrilineal system for women in politics, three voters said that there is connection between this system and women in politics. By contrast, one voter did not see a relationship, and another did not know about this issue. In choosing candidates to vote for, three voters prefer male MPs, one voter bases the choice on the candidate's capability and one tended to follow her feelings. With regard to the performance of MPs, most voters acknowledged that they did not know very much about MPs' performance because this was not covered in the media such that it can be seen and read by voters. In terms of whether politics is an appropriate field for women, two voters said that women are not really suited for this because of the difficulty of a political career for women. One voter said it is all right for women to be politicians as long as they have time for their traditional responsibilities to their families. Another voter felt that it is common for women in Minangkabau to be politicians since the Minangkabau public is familiar with democracy, including in the treatment of men and women. In terms of being trustworthy, one voter mentioned that women should support women politicians, and trust them. Another voter stated that she trusts male MPs because she is the constituent of one of these MPs. While two voters said that they tend to trust male MPs because they have the view that being a politician is a difficult task and it is better that this be done by men. The last voter said that it doesn't matter whether a politician is male or female; what matters is that the person can be trusted. Because trust is related to character, this voter believed it was better to trust the politicians who had a good track record.

Of the seventeen voters who responded to the questionnaire, eleven were women and six were men. The questions were similar to those used for the interviews with the five voters discussed above. No significant differences were recorded by male voters as compared to female. For example, the voters who completed questionnaires had the same range of views about appropriateness of various jobs 
for men and women and most felt that being a politician was more suitable for men than women. In considering the advantages the matrilineal system might give to women, the voters surveyed had a range of opinions as well, but most agreed that communal property should not be used to further an individual's political career.

\subsection{Summary}

This chapter contained an overview of the views of community leaders and members of the voting public about the place of women in politics and the way in which this career choice fits with Minangkabau values and societal structure. While the majority of those individuals interviewed, as well as the voters interviewed and surveyed, felt that women should be involved in politics if they wished to, several expressed various reservations and qualifications. Many expressed the view that there was no inherent advantage or disadvantage of either men or women in the context of politics and success came down to individual attributes or abilities. The significance of these findings will be discussed below in Chapter 7. 


\section{Chapter 7}

\section{Discussion and Analysis}

This chapter contains an analysis of the findings of this study and considers the political, social and cultural contexts that affect the efforts and experiences of women politicians in West Sumatra. These include the values of the matrilineal society of which they are part. Four main themes in the findings are discussed. First, discussion relates to the efforts of female candidates in gaining a seat in parliament by explicating the significant factors that contributed to their winning a seat. Second, the disadvantages of the matrilineal social structure and political system in their campaigns are discussed. The third theme relates to public perceptions of female politicians and the way this affects voting behaviour and may relate to the capacity of female politicians. Finally, the relationship between modern political life and matrilineal society is discussed, which includes vote buying and personal obligation and also political office and social status and lack of women in politics.

\subsection{Significant Aspects in Winning a Seat in Local Parliament}

The findings of this study suggest that there are several factors that the politicians themselves feel have been significant in contributing to their winning a seat in the local parliament in West Sumatra. This set of factors relates to voter targeting, which includes older women, women in rural areas and women in organisations; candidate gender and untapped voter segments; the importance of local origin and local residency; female advantage; and family connections.

\subsubsection{Voter Targeting}

A major finding of this study is that, of five female candidates, four of them attempted to gain support by targeting female voters as their primarily constituency, with one of them targeting a small area she felt had potential voters and paying a great deal of attention to these voters. The politicians who took part in this study tended to target women voters living in rural areas as well as older 
women, farming women and women who belong to organisations. These politicians see these groups as an untapped pool of potential voters who have been overlooked in past elections. There is evidence that this strategy may bring success beyond simply adding to the pool of supporters of specific candidates. The specific social structures of the Minangkabau community make certain types of women voters an even more important target, beyond their numbers alone.

\subsubsection{Older Women}

Reasons to target older female voters are embedded in Minangkabau culture which accords a privileged social status to older women as leaders in their extended families. Decision making for family groups has traditionally been based on consensus among the groups' leaders and so older women have played a major role in decisions that have the potential to impact the group. They are often looked to by younger members of their family for advice and guidance because they are seen to have greater experience and greater knowledge about the issues that affect the extended family. In the past, it was senior women who led their extended family, living in the communal rumah gadang, the Minangkabau traditional house occupied by several nuclear families descending from a single female ancestor.

Today, however, most Minangkabau do not live in a traditionally structured extended family with an older woman as its head. They tend to live in nuclear family groups in single family homes. Some extended families still maintain a rumah gadang, even if it has fallen into disrepair. Many modern families live near their family's communal property, although some have moved away to other areas. Even though they live separately, many still gather periodically at their mother's house. During these gatherings, even if the house itself is modern and is designed for a single family, the function of the traditional house as a forum for communication, where an exchange of information between members can take place, is often maintained. It is the place where younger members of the family become acquainted with the values of their extended family. In this context, the 
role of older women as the heads of extended families still continues and remains strong, and many still play a traditional role in their family group. While the physical rumah gadang, in the sense of a physical structure, may no longer exist, any house can still function as rumah gadang in terms of the social function of supporting discussion and consensus. Thus, in the cultural sense, the conception of the traditional extended family and the role played by older women in this setting is still strong.

The existence of the extended family with older women at its head is significant for female candidates for two main reasons. First, because older women play a significant role in their extended family, when they gather in one house with their younger relatives, the discussion that takes place among the family members tends to centre on issues of importance to the group and it is part of the role of the older woman to provide guidance and leadership which may include persuading younger members to her views. Even though female candidates may not meet all the members of an extended family, the older women may encourage their relatives to vote for the candidate who regularly visits them. In one case, an older woman who had impaired vision, openly mentioned the name of the candidate that she intended to vote for and asked election staff to help her mark her ballot. This indicates a guaranteed level of support a candidate can count on because senior women of this kind stand for their family and are often able to affect the voting behaviour of their younger relatives. Second, from the candidates' point of view, their own extended family tends to offer advice, financial support and information that is useful in their candidacy. This is also largely within the control of the traditional head of the family, normally an older woman. Thus, even though the physical context of the extended family has changed in West Sumatra, interaction as a family in the traditional model remains the norm and has the potential to influence political outcomes, especially in small and rural areas. Family or clan concerns are seen as being relevant to all members who are eligible to vote, and the opinion of a senior female member of the group is often significant in forming the opinions of the other members. 
The role of older women in their extended family as mentioned above demonstrates that they have status as a valued elder. This is embodied in the title Bundo Kanduang which can be applied to women who are leaders in their extended family at the Minangkabau community. While the term Bundo Kanduang comes from a traditional legend of West Sumatra which is part of their oral tradition, in the modern era the legend of Bundo Kanduang is still wellknown and serves as a role model for Minangkabau women. In legend, Bundo Kanduang was a strong woman, the queen of the dynasty of Pagaruyuang and an advisor to her son, the King of Pagaruyuang Kingdom. Historically this dynasty of Pagaruyuang did exist in the seventeenth and eighteenth century and probably much earlier in the region that now is West Sumatra (Drakard 1999). Today, the concept of Bundo Kanduang is maintained as a shorthand term that embodies the traditional desirable attributes in a female leader and also suggests that women, and especially older women, command the same kind of respect and offer the same kind of leadership in their families but also in the traditional institutions of society.

In the modern era, the provincial government of West Sumatra has involved local cultural organisations in development programs. These organisations include the Association of Adat Councils of the Minangkabau World (Lembaga Kerapatan Adat Alam Minanghkabau - KAAM) and Bundo Kanduang organisations. These organisations are financed by the provincial government of West Sumatra and represent the cultural community of the Minangkabau in government. Both LKAAM and Bundo Kanduang are part of the governmental structure from the provincial level to the district level and are involved in many government programs. This reflects a transferral of the role of Bundo Kanduang (and other traditional statuses) into the modern structural environment. This is a manifestation of the idea that members of the public are influenced by their cultural background and this background can and should contribute to decisions made in the public sphere. It should be noted that the role of these organisations has become more prominent since regional autonomy in line with the 'return to 
nagari' movement in West Sumatra. During the New Order, LKAAM and Bundo Kanduang were symbolic with little political or social role and were not very involved in government development programs.

This phenomenon demonstrates two aspects of the term Bundo Kanduang as it is used in West Sumatra. The first is to refer to this organisation that is part of the political-cultural structure of the province where it is seen as representing the interests of women at different levels of the community. Its members are mostly women who are active in community issues and interests. The second aspect is Bundo Kanduang, which is senior women in the extended family who may be approached for advice and suggestions by family members. Today, both aspects of Bundo Kanduang are significant and co-exist in modern society. The organisation is involved in various activities intended to strengthen the position of women who are active in the public space in West Sumatra and to promote government development programs related to women's issues such as women's welfare, literacy, education, health and family planning. This involvement can be seen in empowerment programs, public speeches, training in economics and business management, charities, and religious activities that are sponsored by the organisation.

The dual nature of Bundo Kanduang is important in defining how people in West Sumatra view older women and their role in society. On the one hand, Bundo Kanduang is seen as one of the family leaders; a role that derives from the mythical character of the Minangkabau legend that gives these women a valued status in their family group. On the other, the modern organisation plays a public role in development that is associated with the modern state. This has extended the role of senior women from the domestic sphere into the public sphere and given them a status beyond the family and its traditional interests that encompasses the larger community and its concerns.

The existence of Bundo Kanduang as a concept, as well as the presence of the organisation in the public arena, may enable women to take advantage of the 
traditional status of women as advisors and decisions-makers in a political career. It also suggests that women may become important opinion leaders within their family and social groups as well as at the community level. For this reason, women who are running for political office often see women as the most important voter demographic to win over. The older women are seen as having the potential to influence other voters who may be members of their family or people with whom they interact socially and will be looked to for advice about issues that may affect the welfare of the group.

Further, it is possible that the extension of this traditional role within the extended family into the public sphere through the existence of the Bundo Kanduang organisation has extended the role of older women as decision maker. This especially relates to political issues that might affect the extended family by providing a place and status for this traditional role in the modern state. The result is that older women in some rural areas in West Sumatra are seen by female candidates as especially powerful agents in the community whose lead may be followed by others in a range of issues including in voting behaviour which is an element of the political or governmental context. It also implies that the status of Bundo Kanduang, as one of the cultural elites in Minangkabau society may be aspired to by female politicians in serving in office and also respected in terms of gaining votes.

\subsubsection{Women in Rural Areas}

One of the women who participated in this study, specifically targeted women in rural areas or farming women who mostly live in the highland towns of West Sumatra. This demographic was often overlooked by other politicians such that this woman saw a potential pool of voters who might become loyal supporters of her candidacy. Rural women of this kind are not numerous and may be difficult to reach because they are scattered over a wide region and in areas difficult to reach. 
It is interesting to note that some female candidates saw themselves as taking a risk in focusing on voters in rural areas, and especially women, because many candidates for office seem to have felt that the effort required to reach these voters was not worth the return in number of votes that might be gained. This is particularly the case for male politicians who may tend to feel they can gain enough votes in other ways. Worldwide, data from the Inter-Parliamentary Union (2013) shows that male politicians tend to outnumber female politicians and less than $20 \%$ of national or local parliaments are women. In both developed and developing countries, there tends to be more men in politics than women (Thomas \& Wilcox 2005). This is the case in West Sumatra as well and the imbalance may affect the dynamics of political competition. The small number of female candidates and their more limited opportunities to be elected may result in female politicians trying to maximize votes from areas they know well and are familiar with. This can include the demographics targeted by the politicians in this study, specifically older female voters and the female population in rural areas.

Female politicians in Indonesia tend to compete at the local level of parliament since the opportunities at this level may be easier to get as the voting areas (Daerah Pemilihan - Dapil) that must be won are not as large as those that must be won by candidates for national or provincial parliament. At the local parliament level, candidates may not have many competitors and do not need to expend as much effort to collect votes the way candidates at the national or provincial level do. This may be very significant because, in Indonesia, candidates are expected to visit constituents and interact. Having to work a smaller area, a local candidate may be able to achieve better coverage and much higher recognition than a candidate with a larger area to canvas. Research in other parts of the world has indicated that women use a similar strategy of running at lower levels and targeting smaller areas rather than compete at the provincial and national levels (see, for example Kantola 2009). In addition, this means that a small number of committed women in a given area can swing an election in favour of a particular candidate. This is the situation some of the politicians who 
took part in this study counted on and which, at least in some situations, was a successful campaign strategy.

While voters in urban areas in West Sumatra are generally aware of elections and have often seen campaign materials, women in rural areas may not be aware of who the candidates are for their area and what their qualifications are and what their platform consists of. This research indicates that some of them do not pay much attention to elections and do not follow the issues closely. Many rural voters in Indonesia feel they do not have much choice in elections because the areas where they live have generally not been targeted the way candidates' have targeted urban districts. These rural voters feel they do not have much choice in elections and may not see a great deal of difference between candidates. For women in these areas, elections may not be seen as very important because they seem removed from the day to day concerns of the family and its activities and correspondingly, candidates do not seem interested in the concerns of these voters.

The lack of information about some candidates, campaigns, and elections indicates that many women in rural areas do not feel it is important to vote. Nonetheless, interviews with voters suggest that when a female candidate pays attention to them by regularly visiting them, it is meaningful. They tend to react well to any candidate who comes to their area and takes an interest in their situation. With no comparison, they may be willing to support such a candidate without giving her platform much thought. This is in direct contrast to urban voters who are more familiar with the candidates and have experienced campaign events in their own communities. In this case, rural women may be easier to approach and have served as a reliable source of votes for one of the participants in this study.

\subsubsection{Women in Organisations}

Another finding of this study was that women running for local parliament in West Sumatra often target women who are members of community organisations 
to which they also belong. This can be understood since organisations serve as a setting where the candidates can meet with potential voters from a given geographical location. This is a very important networking opportunity and women voters will often support a candidate they know from a group they are part of. The regular activities of the organisation facilitate the members interacting and allow the candidate to become known to many potential voters. Male candidates, by contrast, cannot take part in the activities of women's organisations as an insider and may be at a disadvantage in terms of interacting with groups of members at one time.

Nonetheless, none of the female politicians who took part in this study tried to target members of the Bundo Kanduang organisation as their primary source of votes. This may be because the members of the Bundo Kanduang organisation are slightly different from the members of other groups. Bundo Kanduang does not have as many members as some other groups and is financed by the government. This means that the members of Bundo Kanduang are committed to support and promote government programs and are not likely to be easily persuaded to vote in a particular way by a candidate. Other organisations, such as BKMT, PKK, Dharma Wanita and Quranic recitation groups whose membership is made up of women from across the community, tend to be dominated by housewives and some of them do not have this kind of government orientation as the way members of Bundo Kanduang do, and their members may be more open to candidates from different parties with different platforms.

Most of the female candidates tended to choose small organisations in rural areas whose members they felt could be easily influenced. While other women's organisations are located mostly in urban areas, including NGO and women's professional organisations, these female candidates did not focus on these organisations. The reason for this is that female candidates may have limited networks; they have felt that it is easier to focus on members of women's organisations in their local area which do not encompass as broad a scope as urban 
ones. A second advantage is that these women generally have access to their local organisations and do not need to develop new contacts in order to approach them.

The female candidates in this study who target older women, women in rural areas and women in organisations noted that they tend to choose potential voters based on the access they have to contexts where they can meet such voters. This parallels a situation discussed in the literature that suggests candidates' ability to influence voters may be linked to their personal relationship with this target demographic (Lahti and Kelly, 2006). For women in West Sumatra, the connection to other women seems to be the most powerful type of relationship they have to draw upon. Thus, it is common to find that female candidates seem to be more confident approaching other women whose situation they are more aware of and who are part of their social network or have some kind of social relationship to them. This may also reflect what at least one respondent observed to be a lack of confidence. These politicians may lack the experience to approach completely unknown voter groups or may be bound by social norms that make this seem inappropriate in West Sumatra.

Despite this, it may not be accurate to conclude that female candidates are not confident approaching male dominated groups to attract potential voters. The women who took part in this study also approached some men's groups. One of the women in this study tried to target one small village by focusing on the whole population of potential voters which included men's, women's and youth organisations (Karang Taruna). Another candidate utilized motorcycle drivers, who are mostly men, by distributing jackets with her name on them in the hope that people would see her name as the drivers travelled around their neighbourhood. One of the candidates visited religious and community leaders regularly and asked them to support her in the election. These phenomena indicate that every opportunity open to them has been taken by these female candidates to gain as many votes as they can. They attempted to find new campaign strategies that were untried by other candidates but that they felt had potential for them. 
While some female candidates are more comfortable approaching women, others have made a special effort to approach male groups. Nonetheless, female candidates are generally more inclined to target female voters which is a reflection of culture and customary behaviour. This can be explained by the fact that the matrilineal system of the Minangkabau community historically segregated people by gender in many activities. Boys spent much of their time at the local prayer house with other boys and men. There, they learned about religion and traditional martial arts, and the experience was seen as preparation for later life when they might leave their home for some time to work and gain experience someplace else before returning home (marantau). Girls, by contrast, were kept in the family home where they helped the women of the family with their work around the house and learned how to manage the family's property.

Traditionally, social activities in West Sumatra also tended to be different depending on gender. The coffee shop (lapau) was an important location for male socializing. Men often spent their free time sitting in coffee shops talking to other men about a range of topics. There was often a television set or newspapers in such shops which encouraged discussion of the news, politics and elections. The Minangkabau community views the coffee shop as an appropriate forum for men to develop and express opinions and also as a place for younger men to practice speaking in public. This is sometimes seen as an element of the egalitarian basis for the society because anyone present, regardless of background, may express an opinion and speakers are judged on their ability to convince those present of their views. There is no such comparable institution for women. Instead, they talk about similar issues with other women as they go about their daily tasks in the village and may meet their friends at public bathing places, by the river while washing clothes, getting water, visiting each other's houses, while doing agricultural work and so forth.

At present, there are still a large number of coffee shops around West Sumatra that serve as gathering places for the men in a given community. They have 
sometimes been used as the focus of campaign activities and for candidates to meet potential voters. By contrast, many of the traditional places for women to meet no longer exist. For example, few people use communal bathing places (as a majority of people have indoor plumbing) or wash clothes in rivers anymore. For this reason, it has not been possible for political candidates to take advantage of these locations to meet with women. Instead, these voters have to be found elsewhere such as in women's organisations or at their homes. Nonetheless, there is still a "correct" way to interact in Minangkabau society based on gender. From the point of view of women who are campaigning, knowledge about where they can appropriately go to meet voters who will be open to them is an integral part of the cultural capital they can use to achieve their goal of gaining political office. They, as well as members of the public, feel more comfortable if these social norms are maintained.

Based on descriptions of voter targeting above, there are no differences in strategy of women politicians in West Sumatra compared to those in other locations. They all seem to target female voters as being the most likely segment to support them. Nonetheless, the data indicated that women voters tend to be older, not younger women. Most people in Minangkabau society consider older women to be senior community members who have to be respected and honoured and whose suggestions should be followed. In rural areas especially, these older women are potential voters who can affect the electability of a candidate. For this reason, the practice of targeting older women and women in rural areas as potential supporters may be more meaningful in West Sumatra than in other areas. This kind of strategy did not guarantee that all four female politicians succeeded in winning a seat in parliament, as various factors affected their candidacy, but three of them did believe that older women were significant in their campaign. Another candidate chose to target one small area as a source of votes from all demographic segments which is another possible strategy in the political content in West Sumatra 


\subsubsection{Candidate's Gender and Untapped Voters' Segments}

One of the participants in this study made an effort to reach voters in one small area that had been overlooked by other candidates. Specifically, this candidate chose to focus attention on all the residents of one small village in the hope that they would vote for her. She was counting on the fact that they might support her because they had not been targeted by other candidates and were not familiar with them. This was a risk because the candidate focused her efforts on this one area instead of campaigning in a wider region. However, the result was a significant number of votes from this village.

This candidate did not have outside support for her campaign and had to rely on the income from her own small business to fund her political activities. By using a combination of strategy and willingness to take risks, she was able to use her resources more effectively to find a pool of voters other candidates had overlooked. She adopted this approach based on her experience when failing to win office in the New Order Era.

The two elections this individual lost were in 1997 and 1999 and to some extent, related to the nature of the political system during that time. There are two possible explanations for her inability to gain office. First, she was a member of an Islamic party that was forced to merge with other Islamic parties to become a single entity. This was a policy of the New Order government early in its administration. Of the three parties that existed at that time, Golkar, the ruling party was strongest and members of the other two were often unable to compete. Second, it is possible that the Islamic party that this woman belonged to may not have supported female candidates to the same extent as their male counterparts since its management may have felt that politics was not really an appropriate career for women. In this woman's case, in her first candidacy in the 1997 election the party put her as number eleven on the list of candidates. This low ranking suggests the low potential the party felt she had to win. In the 1999 election, the system had changed. Five candidates represented their region and 
this woman was second on the list. Nonetheless, she failed to win a seat in the local parliament since her party received only enough votes in the region to put their first ranked candidate in office.

Despite criticism from other party members and the fact that she lost two elections in the New Order period, this candidate finally gained a seat in the regional parliament during the Reform Era for two terms, 2004 and 2009. This occurred in the context of new reforms that gave opportunities to all parties and candidates to campaign more freely than before and allowed voters in the villages to vote for a party other than Golkar without concern. In the Reform Era, this politician realized the situation might allow her to win a seat in the 2004 election. As a senior politician in her party her name was first on the list of candidates. In line with new policy at that time, the election regulations held that candidates who won a seat in the parliament had to be based on their rank on the list of candidates that represented the voting areas.

During her term in parliament from 2004 to 2009, this woman tried to always pay attention to and maintain good communication with her constituents, especially the people in a small part of her own village, Sungayang. These efforts resulted in her re-election in 2009. Even though in this election, her name was second on the list of candidates, a last minute change in the election regulations meant the elected candidates were not taken from the list but chosen based on the number of votes that each candidate received. Her strategy to cultivate a small area with 1,500 potential voters allowed her to win the largest number of votes in election area.

This indicates that her strategy of focusing on a small area and making constant overtures to voters made people familiar with her, aware of her capabilities, and trusting of her. This meant that she was seen as an effective political actor by people in the community and had also earned political trust. This trust, but also her status as the incumbent, helped her to win a second term in parliament. 
This can be seen as reflecting the concept of 'supply and demand' in politics, as described by Norris and Lovenduski (1995) and Krook (2010) where 'supply' refers to the motivation, resources, experiences and capability of candidates. In this case, the candidate was able to provide the necessary 'supply' to fill the available seat in parliament. However, in addition to her personal qualities, the trust in her by the voting public was also significant in her victories. This trust resulted from her personal relationships with people in the area. Political trust is valuable social capital and a resource that can be used in winning votes and supplementing a candidate's 'supply' of political capital. Demand in this context came largely from the parties who are required to have a number of female candidates in order to participate in an election. While in the case of West Sumatra, demand from the public for female candidates does not (or not yet) exist, there are opportunities for women to run that may change this situation in the future. The success of some of the women who took part in this study suggests that the potential for women to build their political reputation is large and has not been fully exploited by candidates across the region.

\subsubsection{The Importance of Local Origin and Social Network}

The women who participated in this study generally came from the areas which they sought to represent through political office. This was an important social asset that allowed them to make use of existing social networks as well as connections their extended family had in the region. This was especially significant for those who came from prominent families where they or their relatives were already familiar to and known by members of the voting public.

The importance of social networks of this kind in West Sumatra should not be underestimated. Votes are often gained because support builds by word of mouth or because people tend to vote for those they know and trust. It is often difficult to build this trust if the candidate does not come from the region and is seen as an outsider. This has been demonstrated many times by Minangkabau people who lived in Jakarta or elsewhere and have tried to run for office in the parts of West 
Sumatra from which their parents or grandparents came. Despite this ancestral connection, they generally lost because they were not viewed by voters as really representing the local community. Candidates who live in the region they wish to represent have had a considerable advantage because of this local feeling.

One of the strengths of local candidates is that their extended family may be known in the candidate's area. This means that voters who do not know the candidate themselves may still be familiar with other members of the extended family as well as with the reputation of the larger family group. For those candidates whose extended family is prominent in a given area this kind of reputation can be a significant advantage as the human capital of the family may be seen as beneficial. Attributes, such as leadership in the traditional context, business success, or high levels of education, may be attributed to the candidate even if he or she has not demonstrated these specific capabilities to the public. This may be especially valuable for women running for office because the matrilineal social structure of the community gives them a prominent position in the extended family and community and associates them more firmly with the family's achievements.

For those candidates who do not come from the region they wish to represent or whose claim to it is only by ancestry, political success can only be achieved if they have strong networks and have developed good relationships with voters. This may take years to do and means that the time and resources needed for a political career are considerable before there is any result. An exception may be a person who is a public figure outside of West Sumatra and who is seen as a success story of domestic migration. Nonetheless, even individuals in this position may have to prove to voters they understand local needs and are capable of addressing the issues of importance in the region.

For women running for the local parliament, connections of this kind are especially important because they have fewer options for their campaign activities and also a smaller pool of potential voters to draw on. As discussed, it 
may be difficult for them to campaign in male-dominated forums such as at the provincial levels, the area from which votes can be attracted is much larger. This is because of prevailing social norms and they may also be running in rural areas with acomparatively low population. For this reason, women like those who took part in this study cannot ignore any possible means for gaining more votes. One of the possibilities is to use their family connections to reach potential voters and pay attention to their needs.

This is an interesting contrast to the experience in western countries where family connections are generally not specifically helpful and may be detrimental. In West Sumatra, the extended family remains the basis for personal identity, and it is important socially to know what family a person comes from, especially in rural areas. Comments by several respondents stressed the importance of considering the welfare of the family in voting, and, for this reason, a candidate whose family will also benefit or suffer from events in the same region as the voters is likely to be more appealing. This person is perceived to have something personal to lose in terms of their own family welfare if they are elected and do not do a good job. For female candidates in particular, coming from the same area as their potential voters offers an even greater advantage because of women's status in the extended family and also because of their responsibility for maintaining its structure and function. A female politician who does not do a good job harms her constituents but also her own extended family which is her personal source of social status and material support (see Smith 2014 for a discussion of the issues of women in politics in matrifocal societies).

\subsubsection{Female Advantage}

This study found that of five female candidates for office in West Sumatra, two clearly used family assets to support their candidacy and campaign while three of them used their own private resources. Nonetheless, all five of these female politicians relied on their family and relatives in their political career. In the matrilineal system of the region, the possibility of using family assets exists for 
women and may be a strong advantage in terms of a political career. By contrast, male candidates do not have this kind of access to family resources and cannot make use of communal assets to fund their personal career.

Family resources that generate income are typically managed by the senior women in the extended family who have the status of Bundo Kanduang. These women decide which members of the family will work, will be given pieces of land, will manage other income-generating assets like fish ponds or orchards, and how the resulting money can be used. In an ideal situation, this is done through a process of consensus that takes into account the individual needs and abilities of different members of the matrilineal family and gives priority to the daughters of the family and their children.

Of the five women who took part in this study, one is a Bundo kanduang in her family and had direct access to communal resources. Nonetheless, she recognized that her extended family only had a small amount of communal property. Thus, she did not utilize her communal property much in running for office. The other four did not share this status, but two were permitted to use family wealth for their campaign activities which were seen as benefitting the larger family group. The remaining two did not use family resources and indicated that their families did not have the level of assets the other participants' families had. For the candidates who had access to family resources, this was seen as a natural and fully appropriate way to finance a political career that they felt was appropriately determined by their own family. Among members of the public surveyed as part of this study, however, $88 \%$ (15 out of 17 ) believed that it was not appropriate for a political candidate to use communal property to support a political career. The sentiment behind this on the part of voters might be the realization that using family communal property to support a political campaign would mean that candidates from the richest families would have a significant advantage and might be able to monopolize seats in a given location simply because of their financial power. 
The women who took part in this study and who were able to use family property did so with no objections from their extended family members. They came from wealthy families who could afford this and who felt that it was appropriate. In fact, most members of the families involved had modern professions and had moved away from their village of origin. For this reason, they did not specifically need the income from their ancestral assets and were not living on their land. This is often the case in West Sumatra today. The traditional houses are often empty with family members using them only around the holiday at the end of the Muslim fasting month of Ramadan. For this reason, the candidates were able to use their ancestral home for campaign activities.

In West Sumatra, having a large family is, in itself, another advantage for candidates. The public seems more confident in voting for a person whose family members they have met or whose family is known locally. The women in this study were able to benefit from the social connections of relatives as well as their own in gaining votes as having a personal connection to a candidate seems to be a strong inducement to vote for them. Voters may feel that even a less known candidate can be judged by his or her family members. In the case of women, their role in traditional family structure is significant in economic success as well as in more private matters within the family group. For this reason, an extended family that is very wealthy or successful in traditional terms is likely to have that wealth and success attributed to its female members. Voters may feel that the personal attributes that allowed the women of a given family to succeed in this way will also make a female politician from the family successful in office.

\subsubsection{Family Connections}

This research found that the success of female politicians in West Sumatra is often dependent on male members of their extended family. In many cases, fathers, brothers, uncles, and brothers-in-law play a role in women's political career, either by providing financial support or through their status in the community which can be used by the candidate to gain public support. 
One situation that shows the importance of a male connection on the maternal side involved a woman who ran in the 2009 election and succeeded in gaining a seat in parliament in the 2009-2014 period. This woman did campaign at coffee shops (lapau) at night but was always accompanied by her maternal uncle (mamak). Coffee shops are not normally frequented by women in West Sumatra, but the men who went there accepted her presence because she was chaperoned by her uncle, implying that family knew about and approved of her using this method. She used these opportunities to talk about her platform and tell people about her candidacy. Of course, her uncle also tried to persuade people in the coffee shop to vote for his niece. The maternal uncle is part of the cultural elite in West Sumatra because of the matrilineal social structure and was able to lend status to this woman's campaign. This reflects the situation noted by Cohen (in Ross 2009) that the traditional elite culture may be involved in and benefit from the political process. This candidate tried to take advantage of the social environment that supports the status of the traditional elite in her campaign.

This case indicates that men have certain leadership roles in Minangkabau extended families that parallel and complement those for women. They also have access to different segments of the community than women and in some cases, may have larger, more varied social connections. Men of course also have influence within their own families, especially in certain relationships that are important traditionally, such as the maternal uncle towards his nieces and nephews. For this reason, the networks and community access male family members can offer candidates is significant as is the impact of being able to reach male voters who may then influence the opinions of people in their social circle. In rural areas especially, the effect of such social networks is particularly important.

Prominent women in West Sumatra have often enjoyed strong support from male relatives, and several historical figures of the $20^{\text {th }}$ century were able to achieve success in the public sphere because of the support of their father and other male 
relatives. These include Rohana Kudus and Zubaidah Ratna Juwita, both journalists, whose experience was well-known in Sumatra at that time. The existence of political dynasties generally begun by a male politician and then being passed down to daughters or other female relatives, is well-known in Asia. This situation has occurred in the Philippines, Thailand, Myanmar, and Bangladesh and also in South Asia (Iwanaga 2008). In Indonesia, former president Megawati Soekarnoputri fits this pattern (see Attanayake 2003; Kingsbury 2005). As discussed in chapter 2, the emergence of Megawati as a national politician and her success in becoming president was, to some extent, related to her father's reputation and supporters, not because of her own political achievements or political skills or her attention to women's issues. This suggests that the political activities of family members can affect women's political participation and experience in Indonesia as it may elsewhere in the world. Family support, especially from close relatives such as a father or brother, may play an important role in helping female politicians gain political status. This may be more significant in the context of the nuclear family. The nuclear family may be important in a political career, as discussed in Chapter 2, as has been observed in Bangladesh, India, with the Kennedy family in the United States, as well as with Megawati and former president Abdurahman Wahid's (Gus Dur) daughter in Indonesia.

The support of the nuclear family for women's political activities also occurs in West Sumatra. This family support is important, not only in relation to close family members such as a father or brother, but may also come from more distant family members such as the mamak (maternal uncle) and other member of the clan. Three of the women who took part in this study have seven and eight siblings that might be potential sources for getting votes. Nonetheless, support from the nuclear family and members of the clan or extended family did not seem to be a significant factor in helping women in their political career like in other places. In West Sumatra or Minangakabau society, it is rare for success in politics to be based on rank or a father's political career. The extended family might help 
during campaign events for example, but it is likely that the ties between members of the extended family are not strong enough to affect the success of female politicians and their political activities. The most important influence is from political institutions which are not based on the traditional Minangkabau culture. It was these political parties and national policy that had a greater impact on the way women achieved in their political career, including during the Reform Era, as experienced by the five female politicians who took part in this study during two election periods.

West Sumatra, which is matrilineal but also strongly Muslim, the support for women by male family members is interesting and superficially contradictory. However, the importance of education and leadership opportunities for women tends to be seen as part of a process of development and progress within the community that is viewed as fitting into the values of Islam as well as traditional customs. It is also appropriate in the context of modern life that has extended the potential social roles for both sexes.

While political families are not uncommon in western countries, there is at least an impression that the ability of several members of one family to gain and hold office is based on merit. This is the case with the Kennedy dynasty in the US for example. The members of such families have to build their own political career, despite benefitting from the family name and reputation and have to have a reasonable track record in order to move up. In Indonesia, the importance of family connections seems to be greater and a family background in politics seems to outweigh other qualifications (see Watson, Jencik \& Selzer 2005, for a discussion of this in relation to women ). The value placed on good family in the context of traditional culture has meant that politicians who have these connections do not have to have leadership qualities that might be demanded by the public of other candidates. For this reason, nepotism remains a problem in Indonesian politics. 
There can be no doubt that some of the women who took part in this study benefitted from their family connections, including the networks built by male relatives who were active in the public sphere, including politics. For them, a political career served two purposes: to fulfil their own aspirations and also to raise the status of the whole extended family. Having members who hold public office is a way of enhancing the reputation of the extended family. Support for those members who wish to enter politics is seen as a good investment that may pay later in greater opportunities for every member of the group.

For the women who took part in this study, the matrilineal system did confer certain advantages, especially in allowing them preferential access to women in organisations and at home and in this way permitted the targeting of the older female demographic that acts as an opinion leader in West Sumatra, They were also able to access their family's communal property in several cases and even if this asset was not available, were able to make use of familiar connections and networks established by other members. Conversely, they also benefitted from the traditional status of women as leaders in the traditional context which may have led to some voters viewing them as embodying this role in the public sphere.

Despite the advantages in terms of status, regard, and material support the matrilineal system offers to women in politics, there are also disadvantages of the system that have the potential to impact on a woman's political career. Similarly, there are aspects of the Indonesian political system that may have a negative effect on the experience of female politicians. These are discussed below.

\subsection{The Disadvantages of the Matrilineal Social Structure and the Indonesian Political System}

The Minangkabau culture and Indonesian political system seem to hinder female politicians in running for political office in specific ways. These include limited access, political parties that act only as a doorway to politics and the nature of the quota system. 


\subsubsection{Limited access}

As described above, social interaction in West Sumatra is different among men than among women, and the activities of each person are limited by the usual social contexts associated with their gender. For the women who took part in this study, these kinds of social rules dictated their political activities, especially at night. There are two aspects of this situation: that of the female politicians themselves and that of the members of the community.

For the female politicians, they often feel that their family obligations must take precedence over their political activities and the evenings are when they have things to do at home and in relation to their children and other family members. This social obligation is deeply ingrained and has been instilled in them from childhood. Despite the privileges and freedom the matrilineal system accords to women, their responsibilities to their family are seen as rightly coming first before activities outside the home. This is the case, not just in politics, but in other types of career as well.

For their part, some people in West Sumatra believe that women should not go out at night. For some members of the public, this view, which probably has roots in the traditional culture of the region, is also seen as being reinforced by Islam. For example, in 2003, a regulation was proposed in the provincial parliament that would forbid women from going out after 7:00 pm without a male relative (mahram) to accompany them. This regulation led to heated debate and was part of a movement to pass local laws that correspond to Islamic principles. In this case, the regulation did not pass in the legislature and was not enacted, but the view it reflects is widely held by the public.

Islam is generally seen as a strongly patriarchal religion and in this sense, conflicts with the matrilineal system of West Sumatra. However, it is the case that certain elements of the traditional system fit well with Islam, which is interpreted in the context of traditional views, anyway. In the case of women's social behaviour, there are some parallels between the two systems. One of these relates 
to the social settings where it is seemly for women to be and under what circumstances. Also, the prohibition on women going out at night is seen by some, not as a restriction of women's freedom, but as a way of protecting them from crime and other antisocial activity people feel generally takes place after dark. Whether accurate or not, there is a perception that the environment is becoming more dangerous and that women are especially at risk (Elshinta 2014; Haluan 2012).

In the context of politics, social norms of this kind have practical implications for female politicians such as those who took part in this study. The time they can devote to political activities may be more limited than that available to men, and it may be more difficult for them to reach potential voters at times those voters are free to meet with them. Men may also have a greater range of social settings where they can campaign. As discussed above, coffee shops are one example of a culturally more appropriate setting for men than women in the context of a political campaign. This means that female candidates have one less setting in which they can meet with voters. But, as noted above, women also have access to social settings that men do not. In West Sumatra, this may be part of the reason there are fewer women in politics than men. The social norms do not seem to favour this type of occupation for women and the settings that are more open to men may be more valuable in the context of gaining votes than those that are more open to women.

Prevailing social norms, at least as indicated by the findings of this study, seem to suggest that suitable occupations for women are teachers, nurses, secretaries and any kind of profession that can be seen as an extension of their traditional roles in domestic space. Involvement in politics means that women must be ready for and understand the kind of barriers they may face. In particular, women are excluded from the practice of preaching in mosques at the communal Friday prayer and also may not offer the weekly evening sermons (wirid mingguan) that are part of religious activities in many mosques. As most of the Minangkabau 
population is Muslim, participation in mosque activities tends to be high and is supported by the social context. For candidates who are targeting voters in remote and rural areas, these weekly gatherings are an important opportunity to speak to potential voters and have their campaign endorsed publically. The preachers, however, tend to be men and generally support male candidates. In some cases, the preachers themselves may be running for office.

Even though coffee shops and preaching in the mosque may not be available to female politicians, the findings of this study indicate that women who enter politics do not view the matrilineal system, with its social restrictions, as a hindrance to their career aspirations. Instead, they were able to utilize the matrilineal social structure, which gave them a privileged and valued role and status in their extended family, as part of their campaign strategy. For example, as noted above, one female candidate was able to use the social connections of her maternal uncle, who was a leader in their community, and accompanied her into typically male social settings. This is the kind of situation noted by Krook (2010), who found that the nature of society and culture can influence women's decisions to enter politics and about how to behave in the political arena. This implies that, to some extent, female politicians in West Sumatra are able to manipulate traditional ideas to support their goals by taking an innovative approach and trying to use the social assets that they can use as women to successfully challenge cultural norms that might otherwise act as barriers to a political career.

This is also similar to a situation noted by Blackwood (2000). Minangkabau women are used to managing their extended family and property, even though this is limited to the non-public context. Nonetheless, they do have an understanding of family politics and may be skilled at negotiation and management. In other words, the matrilineal system provides opportunities for women to be decision makers in their community in the context of adat, and custom. On the other hand, their experience in the extended family may give 
them an opportunity to develop skills that can be used in the public sphere such as in the political arena.

\subsubsection{Political Parties as a Doorway to Politics}

For the women who took part in this study, membership in a political party was an important means to gain a seat in parliament. While mostly political parties did not contribute (financially) to the candidates 'campaign, identification with an established party is fundamental in gaining voter confidence. In fact, the power of the party name is such that party leadership often expects that individuals will donate part of their salary to the party when they gain office as that party's candidate. This phenomenon has grown significantly since the end of the New Order when dozens of new parties emerged. The parties provide a pathway to facilitate a candidate's successful campaign, and it is seen as appropriate that a successful candidate shows their gratitude when successful by contributing to the support of the party.

The right to form political parties is contained in an amendment of the Indonesian Constitution (UUD 1945). Article 28E (3s) states that "Setiap orang berhak atas kebebasan berserikat, berkumpul, dan mengeluarkan pendapat" [Every person has the right to freely associate, assemble, and express opinions] (Asian Human Right Commission 2013). These political parties, some of which align with local or ethnic interests, provide a platform for individuals entering politics. The Indonesian Electoral Commission reported the existence of some 200 parties shortly after the end of the New Order. Of these, 148 registered for the 1999 election, but only 48 were qualified to take part in elections (Ufen 2008). There were 24 parties in the 2004 election and there 15 parties in the 2014 election that included 12 national parties and 3 local parties in Aceh. The declining number reflects the difficulty of smaller and regional parties to meet the requirements set out by the central government to participate in elections. The political parties can be seen as part of the demand side of Indonesian politics providing opportunities but little else for individuals who want to enter politics. 
The large number of parties in Indonesia suggests that there might be increasing opportunities for women to enter political office. Nonetheless, this does not appear to have increased the number of women in parliament. Female politicians seem to be involved in parties and run for office as candidates just to fulfil the requirements of the election regulations. They seem to be used as a tool for the parties to demonstrate affirmative action which is an obligation under election regulations. As a result, parties tend to recruit female politicians without considering their capabilities and capacity. It is enough, in this context, that there are women in the party. During the Reform Era in particular, some parties, especially new ones, have tended to recruit female politicians without concern for their potential. This is important in the context of future electability because it takes time for politicians of either gender to develop the skills required to succeed in the public arena. The women recruited into the parties in this way are frequently not seen as future leaders and may not be offered the opportunities and training they would need to become viable candidates. They lack mentoring and party support. Instead, they are merely place holders, whose function is to ensure the party maintains its legal status, and, in this way, can be seen as mere servants of the party.

The political parties that operate in West Sumatra are branches of major parties spread across the country and run the same platform everywhere. Some of these platforms are more compatible with local views but none are fully consistent with local values. This may result in there being fewer desirable parties for people in West Sumatra who want to run for office and also some parties that are unlikely to gain much community support. This may also serve to reduce the potential opportunities for women as the number of seats is limited as is the number of candidates any one party is likely to run. Combined with the issue of national platforms, there may be structural barriers to greater participation in local politics by female candidates. It is somewhat surprising under these circumstances that politicians in West Sumatra have not had a desire to form local parties as has been done in Aceh. Although local parties in West Sumatra might have platforms 
based on the values of the matrilineal system, this does not seem to have been appealing in the area, at least during the past decade. This likely relates to the different political history of the two regions, which resulted in Aceh being given autonomy to control its own local governance as a result of political accommodation with the central government. In the case of West Sumatra, the New Order government was able to work with community leaders involved in the adat institution, LKAAM, to influence government at the provincial and lower levels. This resulted in a greater level of trust of the central government among the West Sumatran public which, in turn, has made the formation of new (local) political parties unnecessary. Nevertheless, there are indications that the continued strength of the matrilineal system may eventually lead to the formation of local parties that specifically address the needs of the community in this traditional context. These parties, if they survive into the future, may offer greater opportunities for women.

\subsubsection{The Nature of the Quota System}

Indonesia now has a quota system calling for $30 \%$ of available political offices to be held by women. For the political parties, this regulation must be met to comply with election laws and is also seen as a way of attracting female voters by running female candidates. This is sometimes seen as a practice that facilitates female politicians who are not as well qualified as their male counterparts. The women in this study report being underrated by their male colleagues who feel that the women are the recipients of special treatment and do not have to compete in the same way men do.

On the other hand, some observers see the quota system as providing opportunities for women to enter politics for the first time. They feel that the parties might not do much to encourage women to join and run for office if there were no quota in place. Despite this, the quota system in Indonesia is not seen as having increased the number of women in office in a significant way. While it does allow women to participate in elections as candidates, they must still 
compete on their own merits against other candidates, many of whom are male, to win the election. As discussed above, part of the ability to compete successfully in elections comes from prior experience, strategy, and personal abilities that can help a candidate reach voters. For the women in this study, the key to success and gaining political office was to analyse their own strengths and weaknesses and try to make use of information about the voting public. In many cases, this allowed them to win elections. However, the willingness of political parties to run them as candidates was the first step in a successful campaign.

Once in a party, however, the women who took part in this study found they usually were not able to hold strategic positions within the organisational hierarchy. Party leaders tend to prefer men for these positions, largely because of the time commitment involved. Women, it is assumed, will need more time for family obligations and will not be available as much as men for party activities and organizing. The women themselves tended to acknowledge this and agree that they do not have as much time to devote to the party as many of their male colleagues.

The result of this is that many male politicians have a great deal more experience than their female colleagues and have been involved in more aspects of party management. For this reason, the female politicians in this study generally had to follow the directions of their party's leaders and were not able to influence key aspects of the electoral process, such as the order of candidates on preference lists. Experience in politics is one of the main criteria for setting these preferences. Since men tend to be willing and able to make their activities in the public sphere a priority while women usually place such things second after their responsibilities to their family, it is possible to view the political system as favouring men's participation because of the type of demands participation requires. However, it is also important to recognize that many female politicians in West Sumatra accept that their own priorities are also a limitation on their political career. 
For this reason, the women in this study stressed the importance of accurately judging the political environment and making the most efficient use of available resources. They were aware of the need for them to prove themselves and their capabilities to hold office. The $30 \%$ quota for women in political parties was intended to alter the political context in such a way that more women would be able to participate, if only because places would be set aside for them within the parties. While this law was intended to facilitate women's participation in politics and hence be a positive force for encouraging more women to enter this field, it remains an issue of debate in Indonesia.

In West Sumatra, where the matrilineal social system provides recognized ways for women to achieve positions of high social status and leadership, some people do not support this quota system. Three of five community leaders interviewed for this study, for example, feel that such a quota is inappropriate. Their concerns centre on the fact that the existence of a quota may make it difficult for women to be judged on their merits and that they might be assumed to be less capable than men and only on the ballots because of their gender. These leaders believe that men and women should run against each other on an equal basis, and the public should decide from among all available candidates with no places reserved for women. Even the leadership of the Bundo Kanduang organisation, which supports women's participation in politics, does not support the quota. Its leadership feels that the doubt raised by the quota system may disadvantage rather than help women who are, in fact, capable and qualified to hold office.

The reason most often cited by people in West Sumatra for not favouring the quota system is that it is unfair and contradicts the principle of egalitarianism contained in the Minangkabau value system. In this view, men and women should be treated in the same way. While it is the case that the quota system does not seem to have done much to bring more female politicians into the local parliaments, many members of the public have the view that competition for public office should be based on ability, skills, and leadership. This may be a 
result, at least in part, of the fact that women enjoy certain privileges in this society that men do not and that can be seen as greatly helping a political career. One of these is access to family assets as is social status as the head of the family.

For the women in this study, their skills, motivation, and resources were most important in winning a seat in parliament. The three participants who had experience in social and political organisations before running for office felt that the skills they gained in this way helped them greatly during their campaign. Another participant, who did not have this kind of experience but whose potential was recognized by the leadership of her party, was given opportunities to develop the political skills necessary to win an election. In this case, the party management recognized her ability and supported her with a position on the ballot being a reward for her administrative contribution to the party. This suggests that some political parties in West Sumatra are prepared to take a risk with women candidates who they feel have the potential to succeed. The nature of political competition means, though, that a party cannot afford to run unviable candidates, regardless of gender. Both men and women who lack the skills, abilities and no less important, personal resources to win an election are likely to have difficulty obtaining party support. However, this may be a greater problem for women due to the social and cultural context of the region.

In West Sumatra, the political parties have become the means to engage in political activity and are integral to Indonesian democracy. As is the case elsewhere in the world (Bennet 2009), the parties determine who will represent them based on the criteria they believe are most important. Several of the women who participated in this study were chosen by their party without there being any debate about the choice. Even when some of them were not specifically interested in running for office, other party members urged them to enter the election because of their perceived ability to win. This suggests that, in West Sumatra, parties tend to choose candidates that can best win voter support, regardless of gender. This may be a reflection of the principles of egalitarianism and consensus 
that are central to Minangkabau thinking (Naim 1987; Navis 1984) as implemented in the context of the practical requirements of party success.

Considering the nature of the Indonesian political system and also the constraints the traditional social system in West Sumatra places on women, it is possible to view the situation of female politicians as affected by patriarchal views that serve to limit their political activity. Nonetheless, it is important to note that a major force in Indonesian politics is competition among a large number of parties such that having the most viable candidates is primary importance in political contests at every level. For this reason, it is important to distinguish between a desire to keep women out of politics, which was not observed in this study, from a desire to support the candidates most likely to win. In other words, the fact that there are far fewer female politicians than male ones in West Sumatra is generally seen by members of the community as a means of making electoral victory more likely. The nature of the political system does tend to be viewed, both by politicians and members of the public, as being more suitable for men because of the time and contexts where political activity takes place. However, the findings of this study suggest that an experienced female politician who is willing to allocate the same time commitment to a campaign and make an effort to reach the community can succeed in this environment. In fact, this study suggests that women have certain advantages in accessing voters it would be difficult for a male candidate to reach.

\subsection{Female Politicians in the Public View}

The participation of women in the modern political environment was generally well-accepted by the respondents whose views informed this study. Both among voters and local elites, there were no real barriers to women taking part in political activity or running for office. In other words, neither voters nor elites expressed a refusal to vote for female candidates and some were quite open to this possibility. Even those individuals who felt that politics might not be a suitable career for women or that women should focus on their family obligations first believed that these concerns were personal and depended on the candidate herself. 
Several respondents felt that female politicians had not yet distinguished themselves in West Sumatra. Some attributed this to a lack of confidence. However, it is also possible to see this as an extension of their traditional pattern of working from behind to influence matters within the extended family and only giving their opinions outright in certain contexts. It is perhaps more likely though, that the perceived lack of effectiveness is due to the fact the female politicians tend to be less senior than many of their male colleagues and hence are limited in what they can do within the operations of their party. This constraint was mentioned by the politicians themselves but may not be visible to the public.

\subsubsection{Voter Knowledge and Support from Community Leaders}

The findings of this study suggested that voters tend to have little knowledge about candidates' reputation. This may relate to the fact that this research focused on female candidates who mostly represented rural areas with low populations. The scattered and remote areas are often slow to be reached by new information about campaign issues. None of the five female candidates had an official website to promote their programs and campaign in the 2009 election. Similarly, the voters themselves were not that familiar with social media where they could have sourced information about candidates. For this reason, the candidates had to rely on more traditional campaign methods that included distributing pamphlets and brochures, running events, and visiting potential voters in person.

This emphasizes the importance of personal contact and word of mouth in these women's campaigns. Some voters in rural areas with limited access to candidates' information often felt intimidated by the aggressive tactics of political supporters when they went to vote. For this reason, they tended to rely more heavily on the recommendations of senior family members especially when they were not familiar with the candidates themselves. Many did not follow election news closely and had not met the candidates personally as the need for these women to campaign in person necessarily limited the number of people they could talk to directly. For this reason, many voters took the advice of family 
members who were interested in politics or who had a personal connection to a specific candidate or women as leader in their extended family such as Bundo Kanduang.

This led a number of voters to vote for male candidates without giving much consideration to what the female candidates could offer as individuals. The reasons they gave for this included not knowing much about the candidates, taking the advice of family members or believing that men were better able to do a politician's job. This last reason centres on a longstanding idea that the duties of a member of parliament might be too heavy for women, especially in terms of time commitment.

A number of voters specifically stated that they did not disapprove of women in politics but believed that women's first duty was to their home and family. This suggests that voters' choices may be shaped by the idea that politics is not a suitable job for women. While the representation of women in professions that are traditionally male in the west tends to be high, the system allows for accommodations to be made for family needs. Politics, however, tends to be seen as fundamentally different from other professions which have specific work hours and locations. Many people in West Sumatra feel that politics does not have structural boundaries and politicians are at work not just when they are in parliament but also at any time they interact with the community.

This can be seen as the manifestation of a cultural conflict. The matrilineal social system that is traditional custom in West Sumatra gives authority and social status to women but allows time and space for them to carry out their obligations to home and family. The political environment by contrast, represents a modern context that does not allow for these considerations and hence may be unsuitable for women. Voters, it appears, believe that women's inclination will be to give priority to their home life despite their work responsibilities. Under these circumstances, a job, such as politics, which does not allow for this kind of choice may be seen as inappropriate. 
Similar ideas were expressed by community leaders. The community leaders in this research came from various backgrounds that represented the mix of traditional community leaders, cultural, religious and academic. All of them had various views about politicians in general and especially about Minangkabau women as politicians. Many of them did not have a good impression of politicians overall. They felt that both male and female politicians were interested only in their own benefit, not in the needs of the public at large.

Even though they knew specific MPs, their opinions seemed to be based on cases of corruption and scandals that have been heavily covered by the media, rather than on the achievements of the individuals involved. While some community leaders did support female candidates for parliament, others tended to dismiss them, suggesting that the problem is not that a candidate is male or female but relates to capacity and capabilities of the individual. This suggests that these community elites, having seen the behaviour of politicians, remain sceptical about the potential of female candidates, especially those who have not proven themselves capable. These community leaders tend to look for a candidate's qualifications in deciding whom to vote for. Further, community leaders may act as role models for people in the community and they may assure their objectivity in choosing the candidates because of the potential impact their views might have on other voters.

\subsubsection{Voting Behaviour}

The voters and community leaders in West Sumatra also have the opportunity to observe various aspects of politicians' actions which affects their voting behaviour in different ways. The findings of this study suggest there are three broad types of voters in this region: those who know the candidates and might vote for them if family members recommend them; those who do not really know the candidates but may vote for anyone who comes to their area and rewards them for their vote as described above; and those who make a rational assessment of candidates' abilities and choose the person they feel is most qualified. 
The findings of this study suggest that rural voters are more likely to fall into the first and second categories of voters. Some of these voters do know the family of candidates and can make an accurate assessment of the person's potential, especially when friends and family support the person in question. Others have had regular contact with candidates and have received gifts from them. Urban voters, by contrast, tend to be more educated and also to have more complete information about candidates and their background in politics or other professional areas. They may tend to vote based more on their evaluation of the candidate's ability to succeed in the parliament.

People who fall into the first two categories of voter and took part in this study generally felt that women are less suited to politics than men. They seemed to feel that politics fits men better and women should more appropriately enter other professions like teaching. For the third group of voters, gender was not a major consideration as they tend to vote for the person they feel is the best qualified of those available.

In response to this situation, the female politicians who took part in this study used strategies that enabled them to reach untapped voter segments, especially in rural areas and with a strong focus on female voters. Using this approach, four of them were elected to office but one failed to win her race even as the incumbent. In this case, it appears that the strategy of reaching out to rural women was not enough. This points up the fact that the status of women in West Sumatra, which is significant in the traditional context, may not always be applicable in the modern political arena. That is, while a woman running for office may have high social status in the context of her personal life, among her extended family, and in the community, these are essentially spheres which are part of the traditional, Minangkabau social milieu. Politics is part of the modern national context, and it may be that traditional attributes of leadership are different than those the public feels are important for people holding public office. Similarly, women voters may have considerable influence in their own extended families when it comes to 
matters that traditionally fall within women's responsibilities such as disposition of assets where their opinion is highly valued. However, female leaders of the extended family may be seen as less influential when the issue in question is choosing a candidate to vote for. Their knowledge and experience may not be viewed as applying in this specific context.

In Indonesia, women activists sometimes recommend that it would be better if women voted for women. This idea has been seen as a way to encourage more women to enter politics and eventually be elected to parliament. This may be a significant factor when the targeted voters are women as in this study, since women tend to vote in greater numbers than men in many locations in the world including in West Sumatra where the population of women is higher than of men. It has been suggested that, when female candidates discuss and pay attention to women's issues in their campaign, female voters tend to respond positively; a sense of group identity seems to encourage women to vote for other women (Dolan 1998; Swers 1998).

In West Sumatra, however, the concept of women voting for women can be seen as conflicting with the Minangkabau value of egalitarianism that is understood as suggesting that the most qualified person, regardless of gender, should be in a position of leadership. It is this perception that underlies the situation where even community leaders in the matrilineal social structure and Bundo Kanduang who themselves enjoy a special status as women in the community, do not uniformly support female candidates or encourage the general public to vote for them.

\subsubsection{Capacity of Female MPs}

The results of this study indicate that public opinion in the matrilineal society of West Sumatra considers female politicians as separate from women in their role as the dominant person in the extended family. A significant difference is that female politicians tend to be somewhat undervalued, while women in the context of the extended family are respected and valued. Even though matrilineal culture is the background for both of these statuses, in the opinions of community leaders 
and voters different values appear to apply to Minangkabau women as politicians compared to Minangkabau women as Bundo Kanduang.

The community leaders interviewed for this study had mixed opinions about the participation of women in politics in West Sumatra. These views were based on their observations that some female politicians do not or cannot express their opinions in parliament, often do not take part in the decision making process, and are not responsive to social issues in the community. They feel that they judge male politicians by the same standards but that these problems are more often observed among female politicians.

There are two different ways of understanding the observation that female politicians cannot voice their opinions in the parliament. The first is from the point of view of the female politicians themselves and the second is from their circumstances in parliament. In some cases, female MPs cannot express their opinion because they do not have much knowledge about the issues and are not familiar with the drafting of laws that is the main job of parliament. Further, they may not have the self-confidence to voice their views. In addition, male politicians tend to undervalue their contributions and their small numbers in parliament may result in their voices being disregarded.

This situation is observed all over Indonesia and is not unique to West Sumatra (see, for example, Fattore, Scotto \& Sitasari 2010; Selinaswati 2007). This is likely related to the nature of the political system at the national level that is applied in the same way in every province across the country. However, in West Sumatra which is unique in Indonesia in having a matrilineal social system, the assumption that the significant and central position women play in the extended family might carry over into the political arena, appears to be unfounded. In fact, women do not enjoy special privileges or status in politics in West Sumatra and must prove their leadership capability just as men have to. 
The political environment in Indonesia is characterized by corruption, nepotism, malfeasance and other negative behaviour (see Crouch 2010; Henderson \& Kuncoro 2011). In recent years, incidents involving this kind of misconduct have been reported intensively by the press and are well-known to the public. For this reason, women in politics seem to be viewed with the same cynicism accorded to men and both genders may be viewed as simply seeking a job with high pay and prestige. This is separate from the matrilineal context in which women have a privileged status that is consonant with specific social roles in traditional society.

In fact, there are no real differences between the negative conduct of men and women in the political arena and both genders have been involved in the same kinds of cases. It is this knowledge that likely formed the negative image of female politicians that was expressed by the community leaders who took part in this study. This has been reinforced by the fact that the political context has made it difficult for female politicians to address women's problems and create public policy that supports women's needs.

For the future, it seems that female candidates need to be better prepared before an election by developing the knowledge, capabilities, capacity and clear political agenda to generate support among voters. In this way, they may be more effective in their main duty of representing the community. Besides empowering and improving the capacity of the female politicians themselves, the political parties, government and community leaders in West Sumatra should address the question of opportunity and ensure that participation in the political system leads to true involvement for all political actors and individuals of both genders in positions of leadership.

In general, this study indicates that female politicians in West Sumatra, while enjoying some electoral success, have not been able to fully develop their political skills in the current social, cultural and political contexts. As noted by Nussbaum (2011), to achieve one's political ambition, a person must be able to make use of their personal skills within the social situation of which they are part. Capacity 
as well as social, cultural and political capital are required for effective participation in the political arena in West Sumatra, and the women politicians who took part in this study, to the extent that they are representative of all female politicians in the region, still require improvement in these areas. One of the continuing challenges they will face, however, is the tension between traditional values, expectations and the reality of the modern political context in Indonesia. However, maintaining a balance between these two environments depends not just on their own abilities, but also on the perceptions of the community and its leaders whom they depend on for votes. However, as the current political system, which started in the Reform Era, is still relatively new in Indonesia it is likely that this balance will emerge in time as the public as well as politicians continue to adapt to the demands of modern governance in Indonesia.

\subsection{Linkages between Modern Political Life and Matrilineal Society}

West Sumatra with its matrilineal culture cannot be separated from the modern political life of Indonesia, of which it is part. For the public of West Sumatra, which includes the female politicians studied as part of this research as well as voters and community leaders, both of these are elements of a dual identity that encompasses a traditional status in the matrilineal social structure but also a position within the modern Indonesian state.

\subsubsection{Corruption, Vote Buying and Personal Obligation}

An important finding of this study is that vote buying is commonplace and represents the usual practice in West Sumatra. This vote buying can be seen through persuasive activities of candidates toward voters in order to obtain votes. Politicians regularly visit members of the public, talk to them and give them money or other items. On the one hand, this is seen as a spontaneous gesture of generosity on the part of the candidate but on the other it creates a debt of gratitude among the voters that can be repaid by political loyalty as expressed through voting behaviour. These 'political bribes' are common place and are 
completely acceptable in the Indonesia. While this situation has been widely criticized in Indonesia, the public, in fact, expects it.

It may be difficult for the public to resist this kind of action on the part of a political candidate because it is awkward and inappropriate to refuse something freely given. However, this creates an obligation to the candidate that also cannot be easily forgotten. A Minangkabau proverb suggests: 'A debt of money can be repaid; a debt of gratitude is taken to the grave' (Hutang ameh dapek dibaia, hutang budi dibao mati). This indicates the nature of the social obligation incurred by a voter who is given something by a candidate. For people living in rural areas, this kind of traditional relationship remains important because social survival at the village level depends upon creating and maintaining good relationships based on reciprocity as understood in the traditional context.

This is one reason voters in West Sumatra tend to be loyal to candidates who have helped them financially or materially and may overlook the negative characteristics of these candidates. The social bond created by such gifts is very strong and may be difficult to break regardless of what a candidate does. This tolerance which is based on one aspect of the candidate's behaviour may explain why it seems so easy for Indonesian politicians to engage in corruption. They may realize that their constituents will not necessarily show their disapproval by voting for someone else and may also feel that they are justified in enriching themselves because they use some of their resources to reward the voters who put or keep them in office. This is an example of the situation observed by Tonkin (2010) where culture and local conditions determine the nature of people's behaviour in the political context.

Transparency of the kind demanded in western countries has not been a major issue in Indonesian politics. It is not required, for example, that candidates make financial disclosures or that they document where the money for their campaigns came from. This has not been seen as a required element of democracy in Indonesia despite the high level of support for this concept among the public. 
Corruption in various forms is a constant feature of the news in Indonesia especially cases involving prominent people or high level officials. At the local level considered in this study however, there seems to be a kind of conflict in public thinking. While they condemn corruption among public officials, they are very willing to accept gifts from them and do not seem to consider where the resources for these gifts come from. It may be that corruption is less tolerated when it seems remote from the experience of individual members of the public and they do not benefit directly. However, this issue is outside the scope of this study but would be an interesting area for further study.

Despite seeing a need to reward voters for their support, several women who took part in this study did not necessarily consider the voters' opinions once they were in office. The reason for this seems to be that the obligation generated by the practice of financially or materially rewarding voters when voting for the candidate as a return on the gift. Once in office, many politicians appear to feel no further responsibility to the public who elected them and because they paid for the position in a sense, they seem to feel entitled to use it as they see fit. Needless to say, the same possibility applies among voters. While there is an implicit promise to vote when a person accepts a gift from a candidate, there is no way to be sure that he or she really will vote or will vote for the candidate in question. The risk that comes with investment in voters seems to be balanced by the risk associated with a politician's performance in office. At present, voters in West Sumatra seem satisfied with this situation and are not overly critical of their elected representatives at the local level.

The Electoral Commission of West Sumatra reported that there were 7180 candidates who competed for 555 seats in local parliaments in 19 cities and regencies in West Sumatra in the 2009 Election (KPU 2009). This meant that there were 12-13 candidates for every seat and some 6625 individuals who failed to win a seat. For female candidates who took part in this study one had lost an election and saw this failing as a disappointment especially in light of the time 
and financial resources she had committed to her campaign. Despite this, she was able to balance this disappointment with a justification that is found in Minangkabau philosophy. Additionally, as a Muslim, she was able to accept God's will in this issue and accept what had happened. However, it was widely reported that losing in the election led to depression in some male and female politicians who presumably felt they had not been rewarded by the public for their effort. In one highly publicized case, a candidate had to be hospitalized for the mental distress caused by the election results and other similar cases were expected (Ridho 2009).

\subsubsection{Political Office and Social Status}

Social competition is characteristic of traditional Minangkabau society, and one way of gaining prestige and social standing is through a public career. For the women who took part in this study, a successful political career was a way of bringing respect, status, and greater privilege to their extended family. In Minangkabau, this process is referred to as 'raising a sunken log' [mambangkik batang tarandam]. For men, an opportunity to do this might come in the context of marantau, the experience of leaving home for a period of time to work or go to school in another location before (ideally) returning to the village to settle. For women, who do not traditionally participate in this kind of temporary migration, the chance to raise the family's status exists in the local context. In the present day, one way of enhancing the family's standing is by holding political office. In fact, this kind of political service in people's own community is beginning to surpass the prestige from success in another location [rantau]. One reason for this may be the fact that serving in office is a way of contributing to the whole community, while success in the rantau is usually measured by personal wealth gained through business or professional work.

For most people in Indonesia, there is greater prestige associated with being a government employee than in being self-employed and even than having a successful business. This idea may have originated during the Dutch era when 
government employment meant working for the colonial rulers which equated to enormous political and social power. For this reason, the idea that a career in politics is prestigious is very strong in West Sumatra and the parliament is seen as an elite institution. As a public servant, a member of parliament can provide for the whole community. At the personal level, an individual who holds a seat in parliament will be able to make opportunities for family members and, equally important, will have access to people and situations that allow a great deal of money to be made.

This is the main reason the women who took part in this study were supported by members of their extended family in their desire to enter politics. A successful campaign was seen as the best way to help the extended family and, following this, the community they were from in general. This is an example of a specific local condition that might influence women to participate in politics as discussed by Krook (2010). The findings of this study indicate that the entrance of some women into politics may be influenced by changed political conditions during the Reform Era in Indonesia that have included the establishment of a quota for women's participation and the desire of the major parties to recruit female members. However, an equally important motivation seems to be the desire on the part of women and their family members to gain an occupation that can help the group.

In Indonesia, entrance into politics brings many opportunities to enhance individual income and make money by other means. Political salaries are high. It was reported in 2010 that members of the national parliament made as much as 57 million rupiah per month (Carlina 2014). While not this high, salaries of local politicians far exceed the pay for other kinds of employment. In addition, in Indonesia, politicians who have direct access to government institutions will be able to win public tenders, get loans, and solicit donations. The concept of conflict of interest is not well-developed, and it is not seen as incompatible for people who are career politicians and who currently hold office to also have extensive 
business interests and activities. For this reason, political office is seen as a desirable occupation because it is associated with prestige and money and does not carry the kind of ethical obligations associated with public office in the west.

Because of this understanding of political office as something conferring prestige, social status and money, MPs in Indonesian parliaments may not feel much responsibility to their constituents. They feel they have paid for the votes they receive and do not feel they owe the voters anything more. For this reason, most of them do not feel pressure to act in a particular way in the parliament and are free to concern themselves with issues of personal interest or those that are important to their parties. Interestingly, for the five female politicians in this study the reason for entering political office varied from wanting to change government policies in order to improve the welfare of their communities to and improving themselves. Their reasons seem to suggest that money does not appear to have been their main goal at the time they entered politics. However, it is not possible to evaluate the extent to which such views might change in any politician once he or she has been in office for some time. Pressure to 'play the game' may be strong and the implicit rules of Indonesian politics do not seem to support a continuing level of community engagement and responsibility among politicians.

Money may also not have been the main goal of these female politicians early in their career because they expected to rely on their own assets which tended to be fewer than those of other candidates. Two of the respondents stated explicitly that they were aware of their own lack of funds as compared to their competitors. During their campaigns, they spent money but did not offer cash to their constituents and did not make many promises to voters. They recognized that if they had to borrow money to finance this type of campaign, they would have trouble paying it back in the future. For this reason, when these women failed to gain a seat in parliament, they were able to learn from the experience of campaigning but had avoided getting into debt. They generally tried to see the disappointment of losing in the context of Minangkabau values, specifically that 
every aspect of the environment can be instructive as embodied in the proverb 'Let nature be your teacher' (Navis 1984). Further, they also believed that people can only make plans but the God ultimately decides everything. With these ideas as a guide the women who lost their first election tried to understand the situation, analyze their weaknesses, and figure out a strategy to address them. Further, one of the unsuccessful candidates remarked that she was not willing to let her unsuccessful campaign become a source of stress. This type of reaction was likely made possible by the fact that these politicians had limited their personal liability so they were in a position to run again if they chose and did not owe large amounts of money to any individual or institution in their community.

\subsubsection{Lack of Women in Politics}

To win a seat in a local parliament, the politicians who took part in this study exemplified the three step political recruitment process described by Matland (2005) and Norris (1992). They had to first decide to enter politics and then be selected as a candidate by a political party and finally win the election based on voter support. While the first step in this process depended to a large extent on the women themselves, including their capabilities and their resources, the second step depended on political elites and parties, and the third step heavily relied on the voters.

In relation to this, the traditional matrilineal social structure of West Sumatra gives women some advantages that men do not have that can be utilized in the political context. They may have access to family assets that can finance a campaign; they are central figures in the extended family which may offer many kinds of direct and indirect support as well as social capital; and they may benefit from the experience of male members of their extended family who have experience in the political or other sectors. Many of these social and material assets come from their position in the matrilineal system and are, in fact, transferred from the traditional context. Nonetheless, this status may not be completely carried over into the political arena that is part of the modern 
Indonesian nation and has different demands and requirements from the traditional context. Similarly, the second and third steps of women's political participation cannot be separated from the views of the traditional elite and voters toward female politicians.

Even though the advantages accorded to women by their status in the matrilineal society can be said to be greater than the disadvantages they experience in the political arena, it may not be the case that the number of female politicians can be increased in West Sumatra. The matrilineal system of the Minangkabau culture seems to have only minor impacts on women in politics. This is not surprising since modern political life in West Sumatra is based on the Indonesian political system. The system tends to be centralized and its structure is patriarchal. The traditional context of the matrilineal system cannot be fully integrated with the patriarchal political system. However, because the traditional system is outside the functioning of the modern Indonesian state, women in West Sumatra must conform to its demands, and are also subject to its limitations, just as women in any other part of Indonesia are.

The modern state of Indonesia has the potential to play an important role in increasing women's political participation. The matrilineal system in West Sumatra, however, despite giving high status to women in the local community, does not seem to be able to influence the political arena in the region. This suggests that the relationship between the matrilineal kinship system and women's political participation in West Sumatra is weak and there is a place for policy in the national political context to support greater gender balance in politics and among office holders. The political system in Indonesia has undergone considerable change over the nation's history which created opportunities for women to be active in the public sphere, such as the focus on education and to empowerment during the Soekarno Era. During the New Order government of President Soeharto, gender ideology, motherhood and state 'ibuism' became important. But these did not result in more opportunities for 
women to participate in politics. In the Reform Era, the role of the state in the Indonesian political system remained a strong influence in structuring women's political activities, but the conceptualisation of democracy, which became a catch cry. During this period, still did not result in enhanced political participation by women and also did not extend to the inclusion of matrilineal social values in West Sumatra.

\subsection{Summary}

This chapter analyzes the findings presented in Chapter 5 and 6 in terms of the social, cultural, and political factors that were observed to influence women's participation in politics in West Sumatra. While there are certain advantages enjoyed by women who wish to enter politics, there are also barriers specific to them that derive from the context in West Sumatra and that are different from those experienced by men. Overall, however, this study indicates that individual ability, experience, and strategy are extremely important for women and are the main criteria by which many voters judge them as candidates. Nonetheless, there are factors that derive from the traditional matrilineal social system that can serve as advantages for women because of the privilege and social status they have. This study also suggests that it is especially important for women who wish to be elected, to target specific segments of the voting public and the women who took part in this study were especially successful among female voters in rural areas. These voters have been overlooked in the past and could be appropriately approached by female candidates.

Despite this, the matrilineal social system in West Sumatra does not seem to have as much effect on the political career of women as might be expected. The reason for this is likely that the privilege and influence women enjoy in the traditional context does not fully transfer to the modern, national political context where all candidates, both male and female, are bound by the party system and must compete largely based on their own abilities and experience. 


\section{Chapter 8}

\section{Summary, Conclusions and Directions for Further Research}

Women's political participation was discussed in earlier chapters of this thesis in the context of various dimensions based on the matrilineal values and modern political life of West Sumatra. The purpose of this chapter is to review the findings of the study and draw together various aspects of women's political participation in this society. The structure of this chapter provides a summary of this study as well as the conclusions drawn from its results and suggests directions for future research.

\subsection{Summary}

This research investigated the political participation and experiences of female politicians who ran in regional parliamentary elections in the Indonesian province of West Sumatra in 2004 and 2009. These women were members of the Minangkabau culture that is native to West Sumatra and has a matrilineal social structure. It was hypothesized that the traditional position of women as societal leaders might have an impact on the political career and experience of female candidates for political office in West Sumatra. Five women who had either lost or won a seat in five different regional parliaments of West Sumatra were interviewed for this study, specifically about their experience as a member of a political party and candidate in a local election. In addition, members of the local political and cultural elite were interviewed to gain insight into the ways in which female politicians were perceived and the expectations of them on the part of the public. Finally, members of the voting public were surveyed to determine their attitudes toward women in politics, particularly how they compare these candidates to male candidates in the same or similar positions.

The research was designed to determine whether the traditional values of the Minangkabau matrilineal society had an effect in the modern political context of West Sumatra. Specifically, it was assumed that the traditional values of the 
region might be made use of by female politicians in attempting to win a seat in a local parliament. Additionally, it was assumed that members of the public might also evaluate politicians, as leaders in the modern context on the basis of traditional views of women and the customary values of the society.

The research had two aims. First, it was intended to describe the efforts and experiences of female politicians in gaining a seat in a local parliament. Second, the research set out to determine how members of the voting public, including community leaders, viewed these female politicians.

Political participation by women has been an important area of study and research of this kind has been conducted in many nations of the world. The opportunity for women to participate in politics, as candidates and office holders as well as voters, is seen as an important characteristic of a democratic society and a measure of social inclusion and political empowerment. Nonetheless, in many locations, the number of women in parliament has not reached the desired level, despite efforts to encourage political participation. The study of cultural factors that may affect women's participation in politics will contribute to a greater understanding of the political context in relation to women's participation, experience, and electability. The current study is unique in that it considers this issue in the context of a matrilineal society which accords women a leadership status in traditional social settings. It was expected that the political career of women in this society and who themselves were members of this society might be significantly different from that of women from other communities with other kinds of social structures.

The data for this study derived from several sources. These included unstructured, in-depth interviews with three groups of people: female politicians in West Sumatra; community leaders in the same locations; and voters who participated in the elections of 2004 and 2009. Each group consisted of five respondents. The politicians, community leaders and selected voters were interviewed to elicit their views. An additional 20 voters were surveyed by questionnaire. Of the 20 
individuals contacted, 17 returned the questionnaire, and their views were presented in this thesis.

West Sumatra has 19 local parliaments serving regencies and municipal areas. The locations from which informants were chosen were those parliaments where female politicians had taken office following the elections of 2004 and 2009. During this time, female candidates won seats in five different regional parliaments. The female politicians and also the community leaders and voters surveyed for this study were selected from these locations.

The nature of the political activities of the selected female politicians in West Sumatra was described in chapter 5 of this thesis. It was found that the experiences of these politicians were quite varied. Reflecting on their successes and failures, these women were able to provide insight into how traditional Minangkabau values and social norms affected their experiences and helped or hindered their candidature. In a number of cases, these politicians had male relatives, such as a father, brother, brother-in-law or husband who encouraged their political career and supported their campaign. Some of these male relatives were involved in politics themselves and the women followed their lead into the political arena.

The five female politicians noted that members of the community responded to them in a variety of ways. In some cases, they felt that the public underestimated their abilities and did not see them as being as capable as available male candidates. In other cases, they felt that voters saw it as a normal and usual situation for women to enter politics and did not see substantial differences between male and female candidates. In general, their immediate and extended families supported their decision to enter politics but several of the women noted that family members had been surprised by their career choice and wondered whether they would be capable of carrying out political duties. The campaign strategies used by these women also reflected this situation. Of the five female politicians, two were allowed by their extended family to use communal property 
they had a right to for the purpose of supporting their campaign despite these assets not being used for a traditional purpose, The remaining three women either did not have access to such communal property or had independent means they could use to support their political career. The five female politicians faced obstacles in their political careers, as candidates but also once in office. Some of them faced time pressures in fulfilling their roles as mothers, wives and housekeepers in addition to their political obligations. Others were uncomfortable taking part in political activities held at night as it is seen as inappropriate for women in West Sumatra to be out unaccompanied after dark In contrast, it is accepted for men to engage in such activities. In addition, some of the women found that their male colleagues treated them as if they were incapable or lacking in ability compared to men.

The research found that community leaders have a generally neutral opinion about Minangkabau women engaging in political activity. The community leaders did not feel that the existence of female politicians was remarkable because Minangkabau society has always placed women in positions of authority within the extended family and traditional community. In fact, they did not view female politicians as different from male ones and were seen as just as likely to represent their own and their party's interests rather than working for the betterment of society. For this reason, the community leaders did not fully and clearly support female candidates. These community leaders act as role models for people in the community and believe they must not show bias towards any politicians, including female ones. The community leaders also recognized that they had no special influence in the selection of political candidates except as voters.

The interviews with five members of the voting public indicated that they felt it was important to have women in parliament. They made an analogy between parliament and an ordinary household which requires both male and female members to function. Despite believing that women have a place in parliament, 
not all voters voted for female candidates. Three of them said that they chose male candidates for various reasons such as following their husband's and family's lead in voting and believing the male candidate to be more trustworthy or to have shown a greater commitment to his constituents. While one voter said that he checked the record of each candidate before supporting them, another voter said that women should support other women by voting for them but only in situations where the female candidate in question has the capacity to do the job.

None of the five voters knew exactly how the candidates had performed in parliament. The media images of the different candidates were felt to be potentially misleading and created negative images of the individuals involved. Three of the voters felt a political career was appropriate for women as long as they had the appropriate background and skills. One noted that most politicians were men and that this might make it hard for women as a political career is usually seen as being more fitting for men. Data from the 17 voters showed that most of them did not believe female politicians should use communal property as a resource for their political career. Some voters tended to overlook female candidates' capabilities or had less knowledge about them. Most of them thought that politics is not an appropriate career for women.

\subsection{Research Questions}

The research questions for this study were:

1. What are the relevant characteristics of female politicians in the matrilineal society of West Sumatra?

2. What kind of efforts do female politicians in West Sumatra make and what are their experiences in winning seats in local parliaments?

3. How does the voting public in this matrilineal society perceive female politicians as candidates? 
4. How does the Minangkabau matrilineal system affect women's political participation?

The findings of this study suggest that the answer to the first research question about the relevant characteristics of female politicians in the matrilineal society of West Sumatra relates to perceptions of women as leaders in the traditional context. Senior women have specific responsibilities for managing the assets of their extended family and as a result, are viewed with respect and are highly valued, especially if the family is perceived as successful in terms of wealth, education, social standing, and so on. In the modern political context, female politicians are largely judged on their 'capabilities', a nonspecific term that voters and politicians use to mean the ability to do a politician's job, regardless of the specifics involved. This is not different than the demands voters have for male politicians. However, there is little evidence that traditionally desirable attributes of Minangkabau women are also sought by voters except in an indirect sense. In other words, the kind of characteristics that would allow a woman to gain political experience, win office, and carry out the duties of a politician may be the same characteristics that would allow her to successfully head her extended family, but no explicit connection was made between the two by voters, community leaders, or the politicians themselves.

The second research question related to the efforts made by female politicians. The women who took part in this study made special efforts to reach groups of voters who had not been targeted by other politicians in the past. Specifically, these included women in rural areas, older women, and women who were members of community organisations. This was an overt strategy to take advantage of connections they already had or could develop as these groups of voters tended to be difficult to reach in a physical sense and also tended not to have much information about candidates and the elections. In targeting women, the politicians studied were using their social knowledge of the 
Minangkabau system. Women, as the heads of their families, are often opinion leaders with the ability to influence the behaviour of other family members. Similarly, the politicians recognized that they were limited to a certain extent in the places they could campaign because of the social norms of the region and hence decided to target women in women's only environments like organisations and associations with all female membership. They also relied heavily on the social network of their family that they themselves had developed over the years. They found that voters in West Sumatra are much more likely to vote for a candidate they know or whose family they know, who will be seen as more supportive of them and their family's interests.

The third research question related to how members of the voting public perceived female politicians in West Sumatra. The findings of this study suggest that women in politics are perceived in a similar way to men. Voters tend to look for the ability of a candidate to do the job and do not see many differences between men and women. Some voters felt that women might not have as much time to devote to a political career as men but this was not a barrier to voting for a female candidate. They noted that both men and women have been involved in corruption cases in Indonesia and did not feel that either sex was likely to be significantly better in this respect.

The fourth research question related to how the matrilineal social system affected women's political participation. The matrilineal structure of West Sumatran society did not have much impact on women's political participation. Instead, the politicians who took part in this study reported the same issues that have been noted for women in politics in other locations, including male colleagues perceiving them as less competent, difficulty gaining meaningful political experience and having to tow the party line. Some of the women in this study certainly benefitted from the matrilineal system by using communal property belonging to their extended family to support their campaign. While the use of family property was not universal among the 
respondents, the women who had access to these family assets - assets that are not available to men - gained an important source of capital during their political career.

\subsection{Conclusions}

The results of this study suggest that the values of the traditional Minangkabau matrilineal society seem to have only a minor effect on women's political participation in the local parliaments in this area. Nonetheless, even though the traditional matrilineal system did not appear to greatly affect the career progress of female politicians, the Minangkabau value system does contribute to their potential to be elected. The women who took part in this study were able to develop strategies for success that took advantage of their traditional status and the potential for women to lead in certain contexts in traditional Minangkabau society. In particular, several of them recognized that the status accorded to older women in the traditional context could be of value because these women, who were leaders in their own families, might be able to influence younger family members to vote for the candidate in question. The female politicians in this study also tended to target women in rural areas and in women's organisations. This was effective in garnering support because of the segregated nature of certain social activities in West Sumatra and also because the strategy was sensitive to social norms. As women, they were more successful in gaining support in the social contexts associated with women and may have been perceived more favourably because of this strategy.

The women in this study were also able to gain and maintain voter loyalty by interacting regularly with the public in their area, visiting them and attempting to understand their needs. Being part of the local community was a significant asset and the women who used extended family and clan connections to establish a link with voters tended to be successful in that area. For those who had access to communal assets they could use for campaigning, such as the use of a traditional 
house in their village of origin, were more able to use these assets to show themselves to be part of the local community.

For the women who won their electoral races, the advantages associated with their social status as women in the Minangkabau community were a clear benefit. For these women, success in the modern political context can be seen as an extension of the traditional leadership roles for women in this society and they benefitted greatly from access to the traditional assets available to women as leaders in the context of the extended family and clan.

However, the advantages available to women as part of the Minangkabau community that can be applied to a political career did not seem to function to increase the number of women in elected positions. The women in this study still had limited time and access that was not fully compensated for by any advantages they may have enjoyed in political life. Interestingly, the women felt a kind of obligation toward these demands, realising they could not give the priority to their political career that they felt male politicians could. They, as well as others in the community, generally felt their responsibilities to their home and family had to come first. This meant they had less time for their political activities than their male colleagues and this may have been one of the issues that created a perception among some members of the community that women were less capable politicians than men.

Even though they faced obstacles in their political career, the female politicians in this study believed that the values of the matrilineal system contributed positively to their political experiences. While the matrilineal system in West Sumatra is traditional and relates mostly to the longstanding contexts of society that existed before the modern Indonesian state, these women felt that its values inspired them to take up a career in politics. The support of the immediate and extended families, which they felt was available to them as women in a matrilineal culture, was also significant and gave them the strength to endure the rigors of the campaign process and political role. 
The community leaders in the areas where these women lived agreed that the Minangkabau system gives a privileged status to women in the context of the family but this does not transfer to the political arena. Some of them felt that there was no significant impact or connection between the role for women in the Minangkabau extended family and in other roles in the political arena. Most of them believed it was acceptable for women to be involved in politics as an extension of this traditional privilege.

From the point of view of voters, Minangkabau values did not figure into their political decision making process to any great extent. Many of them did not have a great deal of knowledge about politics and were not familiar with the people who represented their area. Many of them lived in rural areas where political considerations had little to do with the realities of their daily life, and they rarely heard anything about politics and the political process unless there was an election. They generally felt that women might interact less with them during the campaign process and might not be able to represent their interests in parliament. Some believed that female politicians were not as capable as their male counterparts. Despite the traditional role for women as leaders within the Minangkabau system and the values of the culture which its members perceive as egalitarian, the women who took part in this study found that their community did not fully support their political participation. They themselves felt guilty if they did not put their family responsibilities first and others tended to believe this was the appropriate course of action for them. This, along with the rather segregated nature of social interactions in West Sumatra, suggests that the principle of the matrilineal system that is commonly viewed as egalitarianism, more properly relates to equivalence of status not of experience. In other words, women are seen as leaders in the traditional context and are central within their own sphere. However, there are areas of leadership for men in traditional society as well. These spheres interact but do not overlap. Women are clearly privileged when interacting in traditional areas of their influence but this privilege may not extend outside the traditional context of family and clan and communal property. 
While the system permits and even encourages their participation in politics and other modern contexts, it does not confer much advantage and female politicians must compete with men based on the same sort of criteria, including experience, knowledge, ability, and political know-how.

The nature of Indonesian political parties and the regulations of the Indonesian government also have a major impact on women's political experience. The $30 \%$ quota system is only a first step for women in politics and does little more than ensure that the political parties give them an opportunity to join. Most female politicians are only ordinary members and are not part of the party elite. As a result, it is difficult for them to have an impact on the party's platform and influence decision making even when they achieve office. The parties do not help much with this either; women who win office must do so largely through their own efforts. In other words, the political parties serve only as a doorway to politics, as the quota system and other similar measures serve only to increase party membership by women, not for them to gain office. Once in office, female office holders, like their male counterparts, must follow the party line and earn elite status through time served and experience.

The results of this study indicate that the matrilineal system and the modern Indonesian political system are complementary but separate spheres. The values of the matrilineal system do not fully match the demands of modern political life. For this reason, the most important attributes for female politicians are personal capabilities, effective strategies to win support and long experience as a member of a political party.

\subsection{Directions for Further Research}

The findings of this study indicate that matrilineal values did not have much impact on the political experience of the women who took part in this research. For this reason, it may be necessary to look further to Indonesia's other regional cultures or factors in the modern environment in an attempt to better 
understand the modern political context in Indonesia as it affects women. Comparable case studies in other parts of Indonesia will indicate whether the experience of women from other ethnic groups is similar or not. Additionally, studies that focus on the specific issues that these women felt were barriers to their career would be valuable in understanding their exact nature in Indonesia and perhaps identifying ways that women's political participation can be boosted. Lastly, as Indonesia has had a number of women in very high level political positions, case studies of these individuals might be useful in understanding the factors that contributed to their considerable success. Additionally, these studies may help us more completely understand how the political context affects women who wish to enter this field.

This study also provided some insight into the interaction of traditional social systems and the modern context in a society that has undergone, and is continuing to experience, rapid social change. This same situation exists throughout Indonesia and in many other societies as well, in other parts of the world. Further research on this point, including research that is not specifically related to women, would be very valuable in extending our understanding of the nature of transition from a traditional social structure to a modern one and the kinds of cultural forces that contribute to the development of modern political systems.

Finally, this study addressed the experience of women in one part of Indonesia with the assumption that the traditional system, which in this case is matrilineal, affected their political experience. Comparable research about the experience of men is also needed in West Sumatra and elsewhere because there may be very significant factors in the traditional context that affect their political experience as well, and it may not be possible to elucidate these factors if they are studied only from the point of view of women. 


\section{References}

Abdullah, T 1985, 'Adat and Islam: an Examination of Conflict in Minangkabau ', in A Ibrahim, S Siddique \& Y Hussain (eds), Readings on Islam in South East Asia, ISEAS, Singapore.

Abidin, Mo 1997, Islam dalam Pelukan Muhtadin Mentawai: 30 Tahun Perjalanan Da'wah Ila'llah : Mentawai Menggapai Cahaya Iman, 1967-1997, Biro Khusus Dakwah Mentawai, DDII, Jakarta.

Abidin, Mo 2011, Minangkabau dan Sistem Kekerabatan, Palantaminang.wordpress.com retrieved 23 October 2011, $<$ http://palantaminang.wordpress.com/minangkabau-dan-sistim-kekerabatan/>.

Afrizal 1996, 'A study of Matrilineal Kin Relations in Contemporary Minangkabau Society of West Sumatra', MA thesis, University of Tasmania.

Alcântara Costa, AA 2010, 'Quotas: A Pathway of Political Empowerment?', IDS Bulletin, vol. 41, no. 2, pp. 18-27.

Amir 2007, Masyarakat Adat Minangkabau Terancam Punah, PT Mutiara Sumber Widya, Jakarta.

Asian Human Right Commission 2013, The Constitution of the Republic of Indonesia of 1945, Asian Human Rights Commission, retrieved 2 March 2014, $<$ http://www.humanrights.asia/countries/indonesia/laws/uud1945_en>.

Attanayake, A 2003, 'Elitism in Women's Political Participation in Sri Lanka within a South Asian Context ', in K Iwanaga (ed.), Women's Political Participation and Representation in Asia: Obstacles and Challenges, NIAS Press, Copenhagen p. 253.

Attubani, R 2012, Generasi Mesum Minangkabau, Media Explorasi, Padang.

Azra, A 2014, 'Reforms in Islamic Education: A Global Perspective Seen from the Indonesian Case', in C Tan (ed.), Reforms in Islamic Education: International Perspectives, Bloomsbury Publishing Plc, London, pp. 59-76.

Balachandran, V \& Sekar, V 2013, 'Societal Changes Due To Empowerment of Women in Tamil Nadu-A Case Study', Journal of Business Management \& Social Sciences Research (JBM\&SSR), vol. 2, no. 1, pp. 7-13.

Begoray, D \& Bannister, E 2010, Reflexivity, SAGE Publication, Thousand Oaks, California.

Beittinger-Lee, V 2009, 'Between Reform and Regression Post-Suharto State and Politics', in V Beittinger-Lee (ed.), (Un) civil society and political change in Indonesia : a contested arena, Routledge, New York 
Benda-Beckmann, Fv \& Benda-Beckmann, Kv 1985, 'Transformation and Change in Minangkabau', in LL Thomas \& Fv Benda-Beckmann (eds), Change and Continuity in Minangkabau Ohio University Center for International Studies Athens, pp. 235-78.

Benda-Beckmann, Kv \& Benda-Beckmann, F 2009, 'Recentralization and Decentralization in West Sumatra', in CJG Holtzappel \& M Ramstedt (eds), Decentralization and Regional Autonomy in Indonesia : Implementation and Challenges, Institute of Southeast Asian Studies, Singapore.

Bennet, JT (ed.) 2009, Not Invited to the Party: How the Demopublicans have Rigged the System and Left Independents Out in the Cold, Springer, New York.

Bessell, S 2010, 'Increasing the Proportion of Women in the National Parliament: Opportunities, Barriers and Challenges', in E Aspinall \& M Mietzner (eds), Problems of Democratisation in Indonesia: Elections, Institutions and Society, ISEAS, Singapore, pp. 219-42.

Biro Pemerintahan 2013, Rekapitulasi : Data Wilayah Administrasi Pemerintah Daerah Prov. Sumatra Barat tahun 2013, Sumbarprov.go.id, retrieved 29 June 2014 ,

$<$ http://sumbarprov.go.id/images/Biro_Pemerintahan/Rekapitulasi\%20Data\%20 Wilayah\%20Adm.\%20Pemerintahan\%20Daerah\%20Prov.\%20Sumbar\%20Tahu n\%202013.jpg>.

Biro Pusat Statistic 2013, Sumatra Barat in Figures, BPS, Sumbar.

Blackwood, E 1995, 'Senior Women, Model Mothers, and Dutiful Wives: Managing Gender Contradictions in a Minangkabau Village', in A Ong \& MG Peletz (eds), Bewitching Women, Pious Men : gender and body politics in Southeast Asia, Berkeley University Press, California.

Blackwood, E 2000, Webs of Power : Women, Kin, and Community in a Sumatran Village, Rowman \& Littelfield, New York.

Bloomberg, L \& Marie, V 2008, Completing Your Qualitative Dissertation : a roadmap from beginning to end, SAGE, Los Angeles.

Bowie, K 2008, 'Standing in the shadow: Of Matrilocality and the Role of Women in a Village Election in Northern Thailand', American Ethnologist, vol. 35, no. 1.

Bush, R 2008, 'Regional Sharia Regulations in Indonesia: Anomaly or Symptom? ', in G Fealy \& S White (eds), Expressing Islam: Religious Life and Politics in Indonesia, ISEAS, Singapore.

Bush, SS 2011, 'International Politics and the Spread of Quotas for Women in Legislatures', International Organization, vol. 65, no. 01, pp. 103-37. 
Bylesjoe, C \& Seda, FSSE 2006, 'Indonesia: The Struggle for Gender Quotas in the World's Largest Muslim Society', in D Dahlerup (ed.), Women, Quotas and Politics, Routledge, New York pp. 259-65.

Carlina, R 2014, Hanya tergiur gaji besar, bila kalah Caleg bisa stress detiknews.com, $\quad$ retrieved 20 January 2014, $<$ http://news.detik.com/read/2014/01/20/122744/2472003/10/hanya-tergiur-gajibesar-bila-kalah-caleg-bisa-stres?n992204fksberitadsfdsf $>$.

Caul, M 2001, 'Political Parties and the Adoption of Candidate Gender Quotas: A Cross-National Analysis', Journal of Politics, vol. 63, no. 4, pp. 1214-29.

Celis, K, Childs, S, Kantola, J \& Krook, ML 2008, 'RETHINKING WOMEN'S SUBSTANTIVE REPRESENTATION', Representation, vol. 44, no. 2, pp. 99110.

Celis, K, Krook, ML \& Meier, P 2011, 'The Rise of Gender Quota Laws: Expanding the Spectrum of Determinants for Electoral Reform', West European Politics, vol. 34, no. 3, pp. 514-30.

Childs, S 2008, Women and British Party Politics : Descriptive, Substantive and Symbolic Representation, Routledge, New York.

Childs, S, Webb, P \& Marthaler, S 2010, 'Constituting and Substantively Representing Women: Applying New Approaches to a UK Case Study', Politics \& Gender, vol. 6, no. 02, pp. 199-223.

Childs, S \& Withey, J 2004, 'Women Representatives Acting for Women: Sex and the Signing of Early Day Motions in the 1997 British Parliament', Political Studies, vol. 52, no. 3, pp. 552-64.

Chiseri-Strater, E 1996 'Turning in upon Ourselves: Positionality, Subjectivity, and Reflexivity in Case Study and Ethnographic Research', Ethics and Representation in Qualitative Studies of Literacy, pp. 115-33.

Christy, CA 1987, Sex Difference in Political Participation: Process of Change in Fourteen Nations, Praeger, New York.

Cockcroft, A, Masisi, M, Thabane, L \& Andersson, N 2010, 'Building Capacities of Elected National Representatives to Interpret and to Use Evidence for Health Related Policy Decisions: A Case Study from Botswana', Journal of Public Health Policy, pp. 1-14.

Cook, TD \& Campbell, DT 1979, Quasi-Experimental Design: Design and Analysis Issues for Field Settings, Houghton Mifflin Harcourt, USA. 
Creswell, JW 2013, Qualitative Inquiry \& Research Design third edn, SAGE, Los Angeles.

Cribb, R 2000, Historical Atlas of Indonesia, Curzon Press, Richmond.

Crouch, HA 2010, Political Reform in Indonesia After Soeharto, Institute of South East Asian Studies, Singapore.

Dahlerup, D 2005, 'Increasing Women's Political Representation: New Trend in Gender Quotas', in A Karam \& J Ballington (eds), Women in Parliament: Beyond Numbers, IDEA Stockholm, pp. 141-53.

Dahlerup, D \& Freidenvall, L 2005, 'Quotas as a 'Fast Track' to Equal Representation for Women', International Feminist Journal of Politics, vol. 7, no. 1, pp. 26-48.

Davis, RH 1997, Women and Power in Parliamentary Democracies: Cabinet Appointments in Western Europe, 1968-1992, University of Nebraska Press, Lincoln, Nebraska.

Denzin, NK \& Lincoln, YS 2003, 'Introduction: Entering the Field of Qualitative Research', in NK Denzin \& YS Lincoln (eds), The Lanscape of Qualitative Research, Theories and Issues, Sage Publication Inc., New York.

Diamond, L 1999, Developing Democracy: Toward Consolidation, The Johns Hopkins University Press, Baltimore, Maryland.

Diani, H 2014, Isu Perempuan hanya Pelengkap dalam Pilpres, Magdalene, retrieved 25 August 2014, <http://www.magdalene.co/news-193-isu-perempuanhanya-pelengkap-dalam-pilpres.html $>$.

Dolan, K 1998, 'Voting for Women in the "Year of the Woman"', American Journal of Political Science, vol. 42, no. 1, pp. 272-93.

Dovi, S 2007, 'Theorizing Women's Representation in the United States', Politics \& Gender, vol. 3, no. 03, pp. 297-319.

Drakard, J 1999, A Kingdom of Words: Language and Power in Sumatra, Oxford University Press, New York.

Elshinta 2014, 2013, Kriminalitas di Sumbar Meningkat 7,3\%, Elshinta.com, retrieved 26 March 2014, $<$ http://www.elshinta.com/v2003a/readnews.htm?id=131083>.

Encyclopedia of the nations 2014, Indonesia-Political Parties, Advameg, Inc., retrieved 30 March 2014, <http://www.nationsencyclopedia.com/Asia-andOceania/Indonesia-POLITICAL-PARTIES.html>. 
Escobar-Lemmon, M \& Taylor-Robinson, MM 2005, 'Women Ministers in Latin American Government: When, Where, and Why?', American Journal of Political Science, vol. 49, no. 4, pp. 829-44.

Evers, H-D 1975, 'Changing Patterns of Minangkabau Urban Landownership, Bijdragen tot de Taal-,n Land-en Volkenkunde (ANTHROPOLOGICA), KITLV, vol. 131, no. 1, pp. 86-110.

Fanany, I 2003, 'The First Years of Local Autonomy', in H Aveling \& D Kingsbury (eds), Autonomy and Disintegration in Indonesia, Routledge Curzon, New York, p. 177.

Fanany, I \& Fanany, R 2003, The Wisdom of the Malay Proverb, Dewan Bahasa dan Pustaka, Kuala Lumpur.

Fanany, R 1997, 'The Nature and Design of Health Promotion Campaigns in West Sumatra, Indonesia', Doctor of Philosophy thesis, University of Tasmania.

Fanany, R, Fanany, I \& Tasady, R 2014, 'The Experience of Old Age in West Sumatra, Indonesia: Culture Shift and Cultural Consonance in the Modern Era', International journal of aging and society, vol. 3, no. 1, pp. 51-9.

Farrar, T 1997, 'The Queen Mother, Matriarchy, and the Question of Female Political Authority in Precolonial West African Monarchy', Journal of Black Studies, vol. 27, no. 5 (May, 1997), pp. 579-97.

Fattore, C, Scotto, TJ \& Sitasari, A 2010, Support for Women Officeholders in a Non-Arab Islamic Democracy: The Case of Indonesia, Australian Journal of Political Science, Routledge.

Ford, LE 2010, Women and Politics: The pursuit of Equity, Wadsworth, Boston.

Franceschet, S 2005, Women and Politics in Chile, Lynne Rienner, Boulder.

Franceschet, S \& Piscopo, JM 2008, 'Gender Quotas and Women's Substantive Representation', paper presented to Midwest Political Science Association Chicago Illinois.

Gelb, J \& Palley, ML 2009, Women and Politics around the World: A Comparative History and Survey ABC-CLIO.Inc, California.

Goettner-Abendroth, H 2012, Matriarchal Societies: Studies on Indigenous Cultures Across the Globe, Lang, Peter, Publishing Inc., New York.

Golafshani, N 2003, 'Understanding Reliability and Validity in Qualitative Research', The Qualitative Report, vol. 8, no. 4, pp. 597-607.

Hadi, W 2009, 'Tigo Tungku Sajarangan', Padang Ekspress. 
Hadler, JA 2008, Muslim and Matriachs: Cultural Resilience in Indonesia through Jihad and Colonialism, Cornell University Press, Ithaca.

Hakimy, IDM 1978, Pokok-Pokok Pengetahuan Adat Alam Minangkabau, Rosda Karya Bandung Indonesia.

Haluan 2012, Waspadai meningkatnya kriminalitas di Sumbar, Harian Haluan, retrieved 23 March 2014, $<$ http://www.harianhaluan.com/index.php?option=com_content\&view=article\& id=18026: waspadai-meningkatkan-kriminalitas-di-sumbar\&catid=13:haluankita\&Itemid $=81>$.

Hamka 1963, Adat Minangkabau Menghadapi Revolusi, Firma Tekad, Jakarta.

Haris, S (ed.) 2007, Partai \& Parlemen, Era Transisi Demokrasi di Indonesia, LIPI (The Indonesian Institute of Sciences), Jakarta.

Henderson, JV \& Kuncoro, A 2011, 'Corruption and Local Democratization in Indonesia: The Role of Islamic Parties', Journal of Development Economics, vol. 94, no. 2, pp. 164-80.

Holtzappel, CJG 2009, 'Introduction; The Regional Governance Reform in Indonesia, 1994-2004', in CJG Holtzappel \& M Ramstedt (eds), Decentralization and regional autonomy in Indonesia: implementation and challenges, Institute of Southeast Asian Studies, Singapore.

Hoodfar, H \& Tajali, M 2011, Electoral Politics: Making Quotas Work for Women, Women Living Under Muslim Laws, London.

Howell, J 2006, 'Women's Political Participation in China: in Whose Interest Elections? ', Journal of Contemporary China vol. November, no. 15 (49) pp. 60319.

Htun, MN \& Jones, MP 2001, 'Engendering the Right to Participate in Decision ker: Electoral Quotas and Women's Leadership in Latin America', in N Craske \& M Molyneux (eds), Gender and the Politics of Right and Democracy in Latin America, Palgrave, London, pp. 32-56.

Ilyas, Y 2006, Kesetaraan Jender dalam Al Qur'an: Studi Pemikiran Para Mufasi, Labda Press, Yogyakarta.

Indrizal, E 2004, 'Problems of Ageing Without Children: A Case Study of the Matrilinial Minangkabau, West Sumatra', in PE Kreager \& S Butterfill (eds), Ageing Without Children: European and Asian Perspective, British Library, London. 
Inter-American Commission on Women 1999, Plan of Action of the CIM on Women's Participation in Power and Decision-Making Structures, Organization of American States, retrieved 19 July 2014, $<$ http://www.oas.org/en/cim/docs/CIM-ActionPlan-

Power\&DecisionMaking[EN].pdf $>$.

Inter-Parliamentary Union 2014, Women in National Parliament retrieved 22 January 2014, <http://www.ipu.org/wmn-e/classif.htm>.

Iwanaga, K (ed.) 2008, Women's Political Participation and Representation in Asia: Obstacles and Challenges Women and Politics in Asia NIAS Press, Copenhagen.

Jacobsen, T 2008, 'Beyond Apsara: Women, Tradition, and Trajectories in Cambodian Politics', in K Iwanaga (ed.), Women's Political Participation and Representation in Asia: Obstacles and Challenges, NIAS Press Copenhagen, p. 149.

Kahin, GT 1952, Nationalism and Revolution in Indonesia, Cornell University Press, Ithaca, New York.

Kantola, J 2009, 'Women's Political Representation in the European Union', Journal of Legislative Studies, vol. 15, no. 4, pp. 379-400.

Karam, A (ed.) 1999a, Perempuan di Parlemen, Bukan Sekedar Jumlah, Bukan Sekedar Hiasan, Yayasan Jurnal Perempuan, Jakarta.

Karam, A (ed.) 1999b, Women in Parliament: Beyond Numbers, Yayasan Jurnal Perempuan, Jakarta.

Karam, A \& Ballington, J (eds) 2005, Women in Parliament: Beyond Numbers, a revised edition International IDEA Stockholm

Karp, JA \& Banducci, SA 2008, 'When politics is not just a man's game: Women's representation and political engagement', Electoral Studies, vol. 27, no. 1, pp. 105-15.

Kato, T 1978, 'Change and Continuity in the Minangkabau Matrilineal System', Indonesia, vol. 25, pp. 1-16.

Kidder, LH \& Judd, CM 1986, Research methods in social relations, Rinehart and Winston, New York.

Kingsbury, D 2005, The Politics of Indonesia, Third edn, Oxford University Press, New York.

Kobayashi, Y 2004, 'Has the Closed Door Opened for Women? The Appointment of Women Ministers in Japan', PS: Political Science and Politics, vol. 37, no. 1, pp. 63-4. 
KPU 2009, Pemilu 2009 dalam Angka, Komisi Pemilihan Umum, retrieved 27 November

$<\mathrm{http}$ //www.kpu.go.id/index.php?option=com_content\&task=view\&id=6430\&I temid $=151>$.

Krook, ML 2006, 'Gender Quotas, Norms, and Politics', Politics and Gender, vol. 2 (2006) pp. 101-28.

Krook, ML 2009, Quotas for Women in Politics: Gender and Candidate Selection Reform Worldwide., Oxford University Press., Oxford, England.

Krook, ML 2010, 'Why are Fewer Women than Men Elected? Gender and Dynamics of Candidate Selection ', Political Studies Review, vol. 8, pp. 155-68.

Krook, ML \& Jalalzai, F 2010, 'Beyond Hillary and Benazir: Women's Political Leadership worldwide ', International Political Science Review vol. 31, no. 1, pp. $5-23$.

Krook, ML \& Mackay, F 2010, Gender, Politics and Institutions : Towards a Feminist Institutionalism, Palgrave Macmillan, Basingstoke, retrieved 16 september 2013, $<$ http://deakin.eblib.com.au/patron/FullRecord.aspx?p=665680>.

La Cour Dabelko, K \& Herrnson, PS 1997, 'Women's and Men's campaigns for the U.S. House of Representatives ', Political Research Quarterly, vol. 50, no. 1, pp. 121-35.

Lawless, JL \& Fox, RL 2005, It Still Takes A Candidate : Why Women Don't Run for Office, Cambridge University Press, Cambridge.

Lerner, G 1986, The Creation of Patriarchy, Oxford University Press, New York.

Lovenduski, J 1993, 'Introduction: the Dynamic of Gender and Party ', in J Lovenduski \& P Norris (eds), Gender and Party Politics, SAGE Publications, London pp. 1-15.

Lovenduski, J \& Karam, A 2002, 'Women in Parliament: Making a Difference ', in A Karam \& J Ballingtong (eds), Women in Parliament: Beyond Numbers A revised edition International Idea, Stockholm pp. 187-212.

Lukes, S 1974, Power: a radical view, Macmillan, London.

Mackay, F 2008, 'THICK' CONCEPTIONS OF SUBSTANTIVE REPRESENTATION: WOMEN, GENDER AND POLITICAL INSTITUTIONS', Representation, vol. 44, no. 2, pp. 125-39, retrieved 30 July 2014, DOI 10.1080/00344890802079607, $<$ http://dx.doi.org/10.1080/00344890802079607 >. 
Mansbridge, J 1999, 'Should Blacks Represent Blacks and Women Represent Women? A Contingent "Yes"', The Journal of Politics, vol. 61, no. 3, pp. 628-57.

Martyn, E 2005, The Women's Movement in Post-Colonial Indonesia: Gender and Nation in a New Democracy, Routledge, London.

Matland, RE 1995, 'How the election system structure has helped women close the representation gap', in L Karvonen \& P Selle (eds), Women in Nordic politics: Closing the gap Brookfield, VT, Dartmouth, pp. 281-309.

Matland, RE 2005, 'Enhancing Women's Political Participation: Legislative Recruitment and Electoral System ', in J Ballington \& A Karam (eds), Women in Parliament: Beyond Numbers, International IDEA, Sweden, pp. 93-111.

McCulloch, N \& Timmer, PCW, Julian 2007, Pathways out of Poverty during an Economic Crisis: An empirical assessment of rural Indonesia, World Bank Publication.

Miksic, J 2004, 'From Megaliths to Tombstones: The Transition from Prehistory to the Early Islamic Period in Highland West Sumatra', Indonesia and the Malay World, vol. 32, no. 93, pp. 191-210.

Milner, H 2002, Civic Literacy: How Informed Citizens Make Democracy Work, Tufts University Press, Massachusetts.

Molyneux, M 2002, 'Gender and the Silences of Social Capital: Lessons from Latin America', Development \& Change, vol. 33, no. 2, p. 167.

Muluk, H \& Malik, I 2009, 'Peace Psychology of Grassroots Reconciliation: Lessons Learned from the "Baku Bae" Peace Movement', in CJ Montiel \& NM Noor (eds), Peace Psychology in Asia, Springer, New York pp. 105-22.

Murray, R 2010, 'Second Among Unequals? A Study of Whether France's "Quota Women" are Up to the Job', Politics \& Gender, vol. 6, no. 1, pp. 93-118.

Naim, M 1985, Implication of Merantau for Social Organization in Minangkabau, eds LL Thomas \& Fv Benda-Beckmann, Ohio University Center for International Studies, Athens.

Naim, M 1987, Conflict and Integration: The Minangkabau and the Javanese in the Dialectics of Nusantara Culture, Kyoto University, Kyoto.

Naim, M 2004, 'Konsep Kepemimpinan Tungku Nan Tigo Sajarangan \& Masalah penerapannya dalam Rangka Kembali ke Nagari', retrieved 13 Agustus 2013, $<$ http://www.cimbuak.net/adat/21-adat-banagari/96-konsep-kepemimpinantungku-nan-tigo-sajarangan-a-masalah-penerapannya-dlm-rangka-kembali-kenagari $>$. 
Nasroen, M 1971, Dasar Falsafah Adat Minangkabau, Bulan Bintang, Djakarta.

Natin, S 2011, 'Perubahan Sosial Kependudukan dan Peran Mamak terhadap Anak dan Kemenakan di Ranah Minang', Mimbar Hukum Fakultas Hukum Universitas Gadjah Mada, vol. 20, no. 2, pp. 333-50.

Navis, A 1984, Alam Takambang Jadi Guru: Adat dan Kebudayaan Minangkabau, Grafiti Pers, Jakarta.

Niven, D 1998, 'Party Elites and Women Candidates: The Shape of Bias ', Women \& Politics, no. 19 (2), pp. 57-80.

Norris, P 1993, 'Conclusions : Comparing Legislative Recruitment', in J Lovenduski \& P Norris (eds), Gender and Party Politics SAGE Publications, London, pp. 309-30.

Norris, P 1997, 'Introduction: Theories of Recruitment', in P Norris (ed.), Passages to Power: Legislative Recruitment in Advanced Democracies, Cambridge University Press, Cambridge, pp. 1-14.

Norris, P \& Inglehart, R 2003, Rising the Tide: Gender Equality and Cultural Change around the World, Cambridge University Press, New York.

Norris, P \& Lovenduski, J 1995, Political Recruitment; Gender, Race and Class in the British Parliament, University Press Cambridge, Great Britain.

Nussbaum, MC 2011, Creating Capabilities: The human development approach, The Belknap Press of Harvard University Press, USA.

O'Donnell, G, Cullel, JV \& Lazzeta, OM (eds) 2004, The Quality of Democracy: Theory and Application University of Notre Dame Press, Indiana, USA.

Patton, MQ 1990, Qualitative Evaluation and Research Methods, Second edn, SAGE Publication, Inc, California.

Paxton, P 1997, 'Women in National Legislatures: A Cross-National Analysis', Social Science Research, vol. 26, no. 4, pp. 442-64.

Paxton, P \& Hughes, MM 2007, Women, politics, and power : a global perspective Pine Forge Press, Los Angeles.

Paxton, P, Hughes, MM \& Painter, MA 2009, 'Growth in Women's political representation: A Longitudinal Exploration of Democracy, Electoral System and Gender Quotas', European Journal of Political Research, vol. 49, pp. 25-52.

Paxton, P \& Kunovich, S 2004, 'Women's Political Representation: The Importance of Ideology ', Social Forces vol. September 2003, no. 82 (1), pp. 87 114. 
Phillips, A 1998 'Democracy and Representation : Or Why Should it Matter Who our Reprentatives Are?', in Feminism and Politics Oxford University Press, New York p. 224.

Pilet, J-B \& Bol, D 2011, 'Party Preferences and Electoral Reform: How Time in Government Affects the Likelihood of Supporting Electoral Change', West European Politics, vol. 34, no. 3, pp. 568-86.

Pitkin, HF 1967, The Concept of Representation, University of California Press, Berkeley.

Population Reference Bureau 2013, Demographic Trends in Muslim Countries, Population reference Bureau, retrieved July 29 2014, $<$ http://www.prb.org/Publications/Articles/2013/demographics-muslims.aspx $>$.

Puskapol UI 2010, Pentingnya Afirmasi Internal Partai Politik untuk Perempuan, Puskapol UI, retrieved 5 April 2011, $<$ http://www.puskapol.ui.ac.id/index.php?option=com_content\&view=article\&i $\mathrm{d}=100 \% 3$ Apentingnya-afirmasi-internal-partai-politik-untuk-perempuan\&catid $=1 \% 3$ Alatest-news\&lang $=\mathrm{id}>$.

Puskapol UI 2011, Kebijakan Peningkatan Keterwakilan Perempuan Pemilu 2004 dan 2009, retrieved 7 April 2011, $<$ http://www.puskapol.ui.ac.id/index.php?option=com_content\&view=article\&i $\mathrm{d}=97 \% 3$ Akebijakan-peningkatan-keterwakilan-perempuan-pemilu-2004-dan2009-\&catid=1\%3Alatest-news\&lang=id $>$.

Putra, EP \& Festiani, S 2013, National Mandate Party no longer Islamist party, Republika Online, retrieved 4 July 2013, $<$ http://www.republika.co.id/berita/en/national-politics/13/01/14/mgm74mnasional-mandate-party-no-longer-islamist-party>.

Radjab, M 1969, Sistem kekerabatan di Minangkabau, Center For Minangkabau Studies Press, Padang, Indonesia.

Ragin, CC \& Amoroso, LM 2011, Constructing Social Research: The Unity and Diversity of Method, SAGE Publication, Thousand Oaks, USA.

Rai, SM 2000, International Perspective on Gender and Governance, Macmillan Press, Great Britain.

Rallonza, LV 2005, 'Women and the Democracy project: A Feminist Take on Women's Political Participation in the Philippines', in K Iwanaga (ed.), Women's Political Participation and Representation in Asia: Obstacles and Challenges NIAS Press, Copenhagen p. 210.

Reiter, RR (ed.) 1975, Toward an Anthropology of Women, Monthly Review Press, London. 
Remenyi, D 2012, Case Study Research : The Quick Guide Series, Academic Publishing International, United Kingdom.

Ridho, R 2009, Rumah Sakit Jiwa Siap-siap Tampung Caleg Gagal, PT.Kompas Cyber Media (Kompas Gramedia Digital Group), retrieved 10 January 2014, $<$ http://regional.kompas.com/read/2009/03/23/15320259/rumah.sakit.jiwa.siapsiap.tampung.caleg.gagal $>$.

Rosenthal, A 1998, The Decline of Representative Democracy: Process, Participation, and Power in State Legislatures, Congressional Quarterly Press, Washington DC.

Ross, MH 2009, 'Culture in Comparative Political Analysis', in MI Lichbach \& AS Zuckerman (eds), Comparative Politics, Rationality, Culture and Structure, Cambridge University Press, New York, pp. 134-61.

Rule, W \& Zimmerman, JF 1994, Electoral Systems in Comparative Perspectives: Their impact on Women and Minorities, Greenwood Press, Westport.

Saanin Dt. Tan Pariaman, HHB 1980, 'Kepribadian Orang Minangkabau', in MA Brower (ed), Kepribadian dan Perubahannya Gramedia, Jakarta

Sainsbury, D 2004, 'Women's Political Representation in Sweden: Discursive Politics and Institutional Presence', Scandinavian Political Studies, vol. 27, no. 1, pp. 65-87.

Sairin, S 2008, Minangkabau yang Gelisah: Sebuah Catatan Singkat, melayuonline.com, retrieved 29 May 2014, $<$ http://melayuonline.com/ind/article/read/819/minangkabau-yang-gelisahsebuah-catatan-singkat>.

Sanday, PR 2002, Women at the Center: Life in a Modern Matriarchy, Cornell University Press, Ithaca, NY.

Sarundajang 2001, Arus Balik Kekuasaan Pusat ke Daerah Pustaka Sinar Harapan, Jakarta.

Schrijvers, J \& Postel-Coster, E 1977, 'Minangkabau Women: Change in a Matrilineal Society', Archipel, vol. 13, 1977, pp. 79-103.

Selinaswati 2007, 'A paradox of Women Representatives in a Muslim Patriarchy and Matrilineal Society in West Sumatra, Indonesia', Masters thesis, University of Hawa'i at Manoa, USA.

Shair-Rosenfield, S 2012, 'The alternative incumbency effect: Electing women legislators in Indonesia', Electoral Studies, vol. 31, no. 3, pp. 576-87. 
Shvedova, N 2005, 'Obstacles to Women's Participation in Parliament ', in A Karam \& J Ballington (eds), Women in Parliament: Beyond Numbers, IDEA Stockholm pp. 33-81.

Silverman, D 2006, Interpreting Qualitative Data: Methods for Analyzing Talk, Text and Interaction, SAGE, London.

Simms, M 1993, 'Two Steps Forward, One step Back: Women and the Australian Party System', in J Lovenduski \& P Norris (eds), Gender and Party Politics, SAGE Publications, London, pp. 16-34.

Sitasari, A 2007, 'Woman and Indonesian Politics: Modernization and its effect on Public Opinion', Conference Papers -- Western Political Science Association, p. 1.

Smith, RT 2014, The Matrifocal Family : Power, Pluralism and Politics, Routledge, New York.

Stockemer, D 2008, 'Women's Representation : A Comparison between Europe and Americas ', Politics, vol. 28 (2), pp. 65-73.

Stockemer, D 2009, 'Women's Parliamentary Representation: Are Women more Highly Represented in (Consolidated) Democracies than in Non-Democracies?', Contemporary Politics, vol. 15, no. 4, pp. 429-43.

Stockemer, D 2011, 'Women's Parliamentary Representation in Africa: The Impact of Democracy and Corruption on the Number of Female Deputies in National Parliaments', Political Studies, vol. 59, no. 3, pp. 693-712.

Studlar, DT \& Moncrief, GF 1999, 'Women's Works? The Distribution and Prestige of Portfolios in the Canadian Province', Governance: An International Journal of Policy and Administration, vol. 12, no. 4, pp. 379-95.

Sunuri, S 2011, Datuak Tumangguang Sutan Sulaiman, Kepala Laras Sungai Puar, retrieved 13 January 2014, $<$ http://urangminang.wordpress.com/tag/tuanku-lareh/>.

Suryakusumah, J 2004, Sex, Power and Nation, Metafor Publishing, Jakarta.

Swanborn, PG 2010, Case Study Research : What, Why and How?, SAGE Publishing, Los Angeles.

Swers, ML 1998, 'Are Women More Likely to Vote for Women's Issue Bills than Their Male Colleagues?', Legislative Studies Quarterly, vol. 23, no. 3, pp. 43548 . 
Taylor, EB 1924, Primitive Culture : Researches into the Development of Mythology, Philosophy, Religion, Language, Art, and Custom, 7th edn, Brentano's, New York.

Taylor, GR 2005, Integrating Quantitative and Qualitative Methods in Research, University Press of America, Maryland.

Taylor, SJ \& Bogdan, R 1984, Introduction to Qualitative Method Research, John Willey \& Sons, Toronto.

Thaib, PR 2011, Menempatkan Diri Dalam Berbagai Peran Menurut Adat Dan Budaya Minangkabau, palantaminang.wordpress.com, retrieved 23 October 2011, <http://palantaminang.wordpress.com/2011/07/28/menempatkan-diridalam-berbagai-peran-menurut-adat-dan-budaya-minangkabau/>.

Thames, FC \& Williams, MS 2013, Contagious Representation : Women's Political Representation in Democracies around the World, NYU Press, New York.

Thomas, LL \& Benda-Bekmann, Fv (eds) 1985, Change and Continuity in Minangkabau: Local, Regional, and Historical Perspectives on West Sumatra, Center For International Studies, Ohio University, Athens, Ohio.

Thomas, S \& Wilcox, C (eds) 2005, Women and Elective Office : Past, Present, and Future, Oxford University Press, New York.

Tjahaja, L 1976, Minangkabau Tanah Adat, Ganaco NV, Jakarta.

Tomsa, D 2008, Party Politics and Democratization in Indonesia : Golkar in the Post-Suharto Era, Taylor and Francis, Hoboken, retrieved 12 July 2014, $<$ http://deakin.eblib.com.au/patron/FullRecord.aspx?p=350212>.

Tonkin, A 2010, 'Why Western Democracy is not a Global Notion: Required a Values Based System of Governance', Integral Leadership Review, vol. 10, no. 2 , pp. 1-7.

Towns, AE 2012, 'Norms and Social Hierarchies: Understanding International Policy Diffusion "From Below”, International Organization, vol. 66, no. 02, pp. 179-209.

Tripp, AM, Casimiro, I, Kwesiga, J \& Mungwa, A 2008, African Women's Movements : Changing Political Landscapes, Cambridge University Press, Cambridge, retrieved 4 September 2013, $<$ http://deakin.eblib.com.au/patron/FullRecord.aspx?p=412733 $>$.

True, J \& Mintrom, M 2001, 'Transnational Networks and Policy Diffusion: The Case of Gender Mainstreaming', International Studies Quarterly, vol. 45, no. 1, pp. 27-57. 
Ufen, A 2008, 'From Aliran to Dealignment: Political Parties in Post-Suharto Indonesia', South East Asia Research, vol. 16, no. 1, pp. 5-41.

Uker, D \& Fanany, R 2011, 'The Traditional Decision-Making Process of Berkaul in Tanjung Emas, West Sumatra: Its Nature and Significance', Journal of Social Issues in Southeast Asia, vol. 26, no. 1, pp. 1-15.

Venny, A 2010, Here to Bring a Change: A Reflection of the Experience of the 2004-2009 Women Members of Parliament, Parliamentary Support Programme UNDP, UNDP, Jakarta.

Verba, S, Schlozman, KL \& Brady, HE 1995, Voice and Equality Civic Volunteerism in American Politics, Harvard University Press, Massachusetts.

Vreede-de Stuers, C 1960, The Indonesian Women: Struggles and Achievement, Mouton \& Co, The Hague.

Vreede-de Stuers, C 1992, 'The Life of Rangkayo Rahmah El Yunisiya', in E Locher-Scholten \& A Niehof (eds), Indonesian Women in Focus, second edn, KITLV Press Netherlands.

Vreede-de Stuers, C 2008, Sejarah Perempuan Indonesia: Gerakan dan Pencapaian, Komunitas Bambu, Depok.

Watson, RP, Jencik, A \& Selzer, JA 2005, 'Women World Leaders: Comparative Analysis and Gender Experiences', Journal of international women's studies, vol. 7, no. 2, pp. 53-76.

Wichelen, Sv 2006, 'Contesting Megawati: The Mediation of Islam and Nation in Times of Political Transition', Westminster Papers in Communication and Culture, vol. 3, pp. 41-59.

Wierenga, S 1995, Subversive Women, Raj Press, India, New Delhi.

Wierenga, S 2001, Sexual Politics in Indonesia, Palgrave MacMillan, New York.

Williams, MS 1998, Voice, Trust, and Memory: Marginalized Groups and the Failings of Liberal Representation Princeton University Press, Princeton, NJ.

Witz, A 1992, Professions and Patriarchy Routledge, New York.

Xydias, CV 2007, 'Inviting More Women to the Party ', International Journal of Sociology vol. 37, no. 4, pp. 52-66.

Yin, RK 2003, Case Study Research: Design and Methods, Sage Publication, California.

Yin, RK 2012, Application of Case Study Research third edn, Sage, California.

Young, IM 2000, Inclusion and Democracy, Oxford University Press, Oxford. 
Zed, M 2011, PRRI dalam Pergolakan Daerah tahun 1850-an, situs komunitas nagari.org, retrieved 19 June 2013, $<\mathrm{http}: / /$ www.nagari.or.id/?moda=palanta\&no=119>. 